\title{
FUNGI
}

\section{AND HOW TO KNOW THEM}

\section{E.W. SWANTON}

(1)

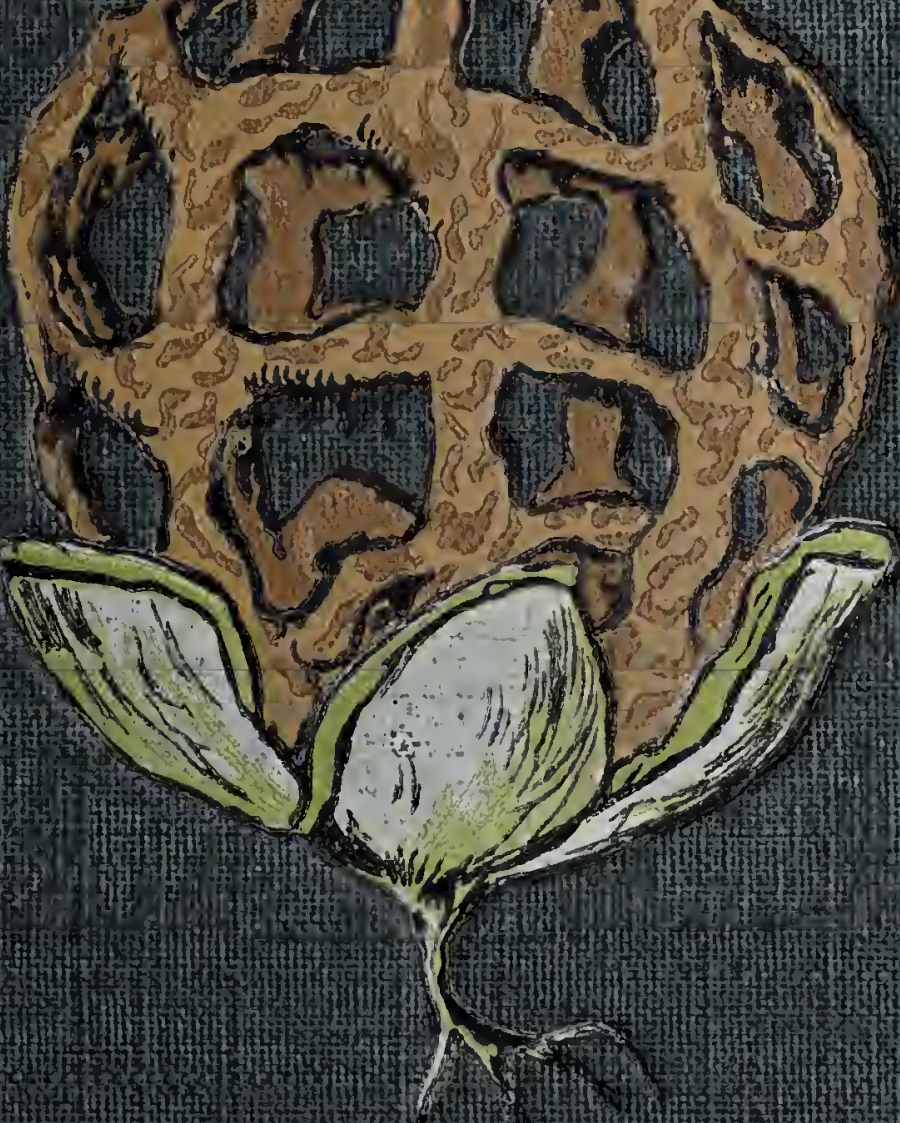




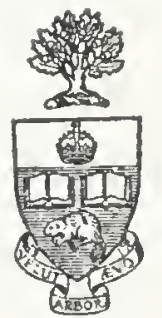

\section{Library}

of the

University of Toronto 
G. Aavidson.

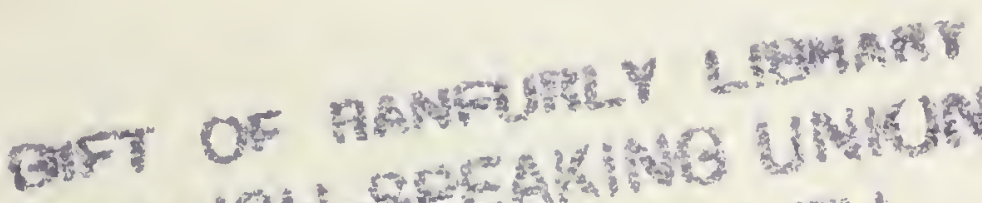
ENold

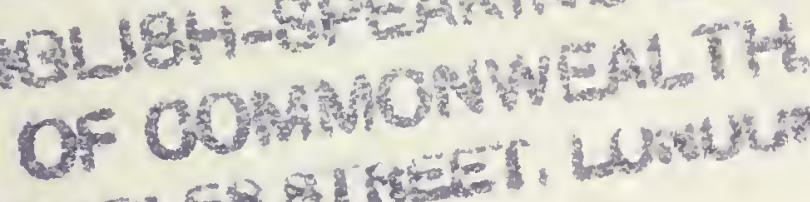
M. OHARLE 
Digitized by the Internet Archive in 2018 with funding from University of Toronto 
FUNGI AND HOW TO KNOW THEM 



\section{DESCRIPTION OF PLATE I}

\section{COMMON WINTER SPECIES}

FIG. I.-Collybia velutipes.

FIG. 2.-Ditto, section.

FIG. 3.-Peniophora incarnata.

FIGs. 4-8.-Polystictus versicolor (see p. 12).

FIG. 9.-Stereum hirsutum.

FIG. Io.-Tremella mesenterica. 


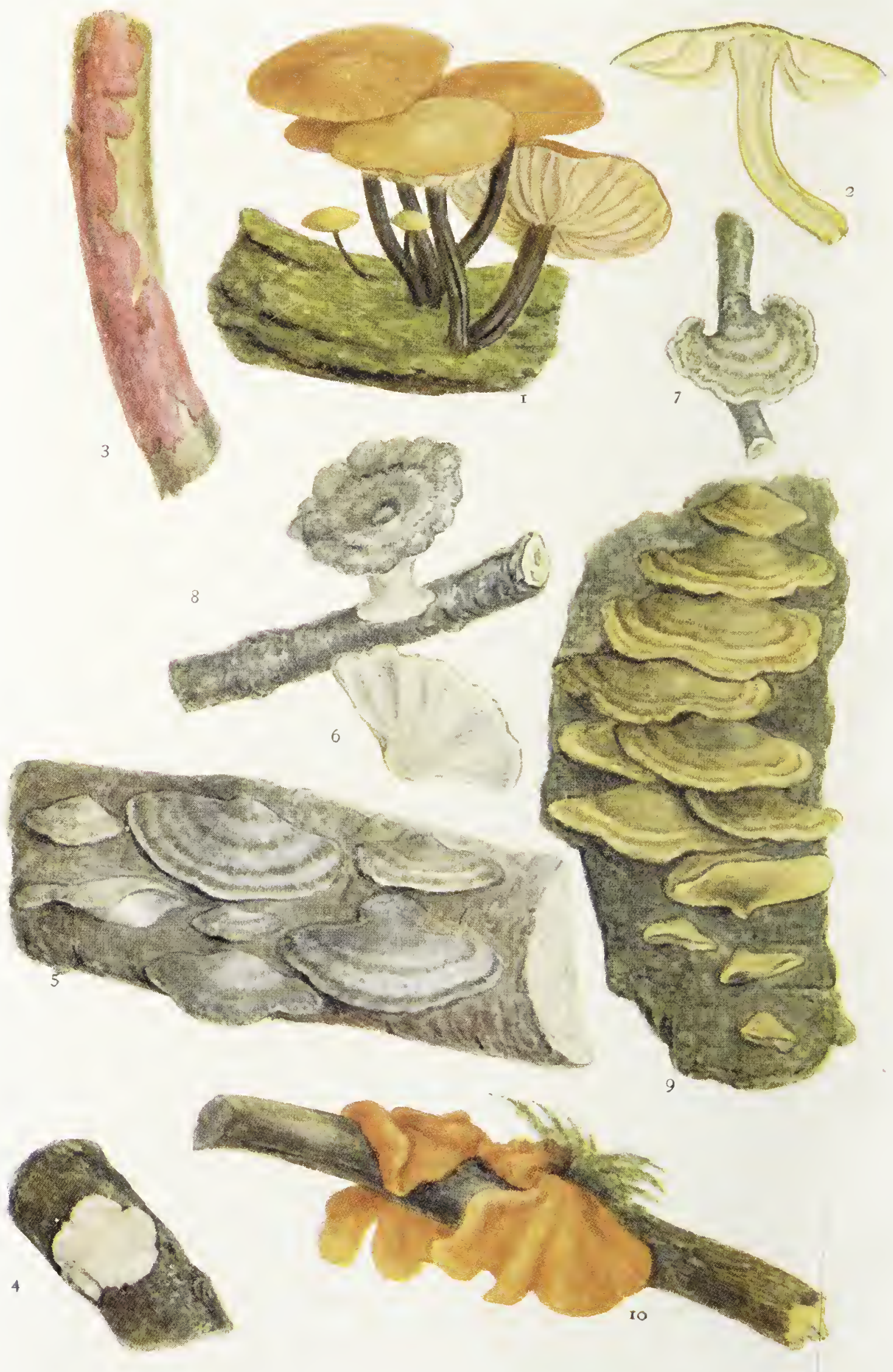




\section{F U N G I}

\section{AND HOW TO KNOW THEM}

\section{AN INTRODUCTION TO FIELD MYCOLOGY}

BY

\section{E. W. SWANTON}

MEMBER OF THE RRITISH MYCOLOGICAL SOCIETY, AND OF THE ASSOCIATION OF ECONOMIC BIOLOGISTS; CURATOR OF THE EDUCATIONAL,

MUSEUM, HASLEMERE

WITH I6 COLOURED AND 32 BLACK-AND-WHITE PLATES, DELINEATING UPWARDS OF 240 SPECIES, CHIEFLY DRAWN BY

M. K. SPITTAL

METHUEN \& CO. 36 ESSEX STREET W.C. LONDON 
First published in I909. 


\section{PREFACE}

$7 \mathrm{HE}$ fungi comprise a group of plants second to none 1 in their capacity for evil. Gigantic sums, amounting to millions annually, are spent in combating the ravages of fungoid pests, but we are only just beginning to realise that the rising generation should acquire at least an elementary knowledge of this most important branch of botany. At the British Association Meeting in I907, Mr. Carleton Rea emphasised the serious claims of mycology for greater attention than it had up to that time received, and he expressed the hope that local natural history societies and field clubs would undertake the investigation of the fungi occurring in their districts, and provide periodical exhibitions of them. Since then the study of fungi has received considerable impetus, and many inquiries have been made for an elementary book on the subject.

There are books innumerable on common wild flowers (this branch of botany seems to have been given an undue importance by teachers of what is nowadays called " naturestudy"), but there are very few indeed which deal with common fungi: I hope that this little book, which is intended to serve as an introduction to the Fungus Floras and Textbooks of Cooke, Stevenson, Massee and other authorities, will supply what I have often been assured is a desideratum.

As with the wild flowers so it is with fungi, many range 
throughout the world. Mr. C. G. Lloyd, a well-known collector of fungi, writes: "The more specimens we receive from all portions of the world the more strongly we become convinced that fungi are plants of wide distribution, and that the fungus flova of the rovld is practically the same" (the italics are his).

Half a century ago, Berkeley noted that out of 275 species then recorded from Tasmania, no less than I 3 were British, and 20 others were European species that may be expected to occur in Britain; yet so little has the study of fungi advanced in popular estimation that I have on several occasions astonished people by remarling that a large number of fungi are cosmopolites!

It is only by first creating an interest in the larger and more familiar species that we can expect to stimulate inquiry into the life histories of the minute forms; and the majority of the parasites so dreaded by farmers, gardeners and foresters are of microscopic dimensions.

It is the "larger fungi" only that have received attention in this book, and of these, for the most part, only very common ones. The term includes those species that can be identified without the aid of a microscope, all of which are comprised in the two great Orders known as Basidiomycetes and Ascomycetes.

The genera of the Basidiomycetes have been considered in detail: this was necessary, though it involved allusion to some very rare species and a few insignificant ones, to enable the student thoroughly to grip the principles of classification.

An examination of the keys to the Families and Genera will speedily reveal a fact that has been doubted by many, viz., that the bases of classification of fungi are just as firmly fixed as are those of our flowering plants; it is, there- 
fore, no more difficult to identify a fungus than it is to diagnose a flower.

The majority of the Ascomycetes being minute species that can only be determined precisely with the aid of a microscope, I have not considered it necessary to outline the families and genera of this Order, and have noted only large, and for the most part common species which can be easily identified by macroscopic characters.

I have much pleasure in here acknowledging my great indebtedness to my friend Miss M. K. Spittal for her very excellent coloured and black-and-white plates.

My thanks are also due to Mrs. Carleton Rea for the coloured drawings reproduced on Plate XLIII.; to the British Mycological Society for the loan of a block; to Sir Jonathan Hutchinson, F.R.S., for kind permission to illustrate specimens at his Educational Museum, Haslemere; and to Mr. C. G. Lloyd of Cincinnati, U.S.A., who has most generously permitted the reproduction of many illustrations from his privately printed monographs and papers concerning the Gasteromycetes.

E. W. SWANTON

Haslemere

September, 1909 



\title{
CONTENTS
}

\section{PART I}

CHAPTER

PAGE

I. Development-The Spore, Myceliom, and Sporophore I

II. Method of Spore Dispersal - - - - - I7

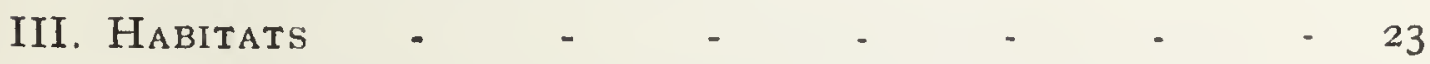

IV. Saprophytes and Parasites $\quad-\quad$ - $\quad$ - $\quad$ - 27

V. Economic and Edible Species - $\quad$ - $\quad$ - 34

VI. On Collecting, Exhibiting, and Preserving Fungi - 37

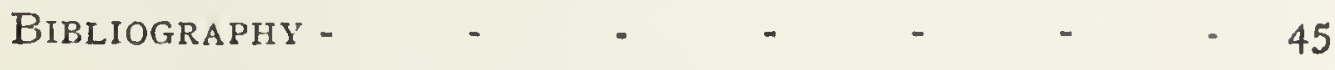

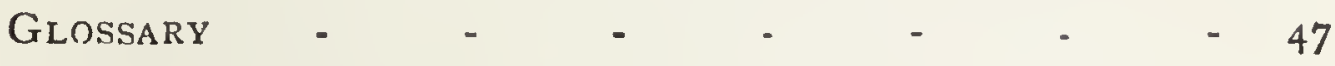

\begin{abstract}
PART II
CLASSIFICATION AND DESCRIPTION OF SPECIES
\end{abstract}

Gasteromycetes

HYMENOMYCETES

Ascomycetes -

APPENDIX

IndeX of Species Illostrated

INDEX - 


\section{LIST OF PLATES}

The coloured ones are marked by an asterisk. Excepting where otherwise indicated, the plates are from drawings by Miss $M . K$. Spittal.

PLATE

I. * Common Winter Species FACING PAGE

II. Development in Gasteromycetes [E. W. S.] Frontispiece

III. Rapidity of Growth in the Phalloidaceæ [C. G. Lloyd] - II

IV. Development in Hymenomycetes [E. W. S.] - - I3

V. Development in Ascomycetes [E. W. S.] - - . 15

VI. Dispersal of Spores [E. W. S.] - - - - - $\quad$ I9

VII. *Common in Fir Woods $\quad$ - $\quad-\quad-\quad-23$

VIII. *Common in Beech Woods - - - $\quad$ - 23

IX. *Common in Open Pastures - - - $\quad$ - $\quad-23$

X. Small Agarics occurring on Dead Leaves, elc. - • 23

XI. Large Fungi Parasitic on others - - - - $\quad-25$

XII. A destructive Fir-Wood Parasite (Fomes annosus) - $\quad-28$

XIII. Destructive to Living Trees - - • - 30

XIV. Parasites on Living Leaves, etc. - - - - $\quad-32$

XV. *Some Edible Species $\quad-\quad$ - $\quad$ - $\quad$ - $\quad$ - 35

XVI. Diagrams Explanatory of some Terms [E. W. S.] - 55

XVII. Truffles and False Truffes - $\quad-\quad-\quad{ }^{-} \quad-\quad 5^{8}$

XVIII. Common Earth-balls [C. G. Lloyd] - • - - 60

XIX. Birds'-nest Fungi (Nidulariaceæ) - - - - - 62

XX. Two Common Puff-balls [C. G. Lloyd] - - - $\quad 65$

XXI. Some Typical Puff-balls [C. G. Lloyd] - - - - 66

XXII. Some Rare Earth-stars [C. G. Lloyd] - - - - 68

XXIII. Earth-stars (Geastræ) [C. G. Lloyd] - - - 70

XXIV. Stinkhorn Fungi (Phalloidaceæ) [C. G. Lloyd] - $\quad-7^{2}$

XXV. Common Stinkhorn (Phallus impudicus) [C. G. Lloyd] - 72 
PLATE

FACING PAGE

XXVI. Types of Gelatinous Fungi (Tremellinaceæ) - $\quad 76$

XXVII. Types of Fairy-Club Fungi (Clavariaceæ) . - SI

XXVIII. Cauliflower Fungi (Genus Sparassis) [British Myco-

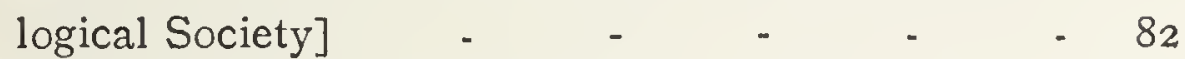

XXIX. *Some Fairy Clubs (Clavariæ) - . - - $\quad$ - 84

XXX. Types of Leathery Fungi (Thelephoraceæ) - - 86

XXXI. Types of Teeth-bearing Fungi (Hydnaceæ) - - 9 I

XXXII. Types of Pore-bearing Fungi (Polyporaceæ) - $\quad 95$

XXXIII. *Common Polypores - $\quad$ - $\quad$ - $\quad$ - $\quad$ - 102

XXXIV. *Common Bolets - - - - - . $\quad$ - 104

XXXV. Diagrams showing Modes of Gill Attachment [E. W.S.] I07

XXXVI. Types of Gill-bearing Fungi (Agaricaceæ) - - 107

XXXVII. *Black-spored Agarics (Melanosporæ) - - - - II2

XXXVIII. *Purple-black-spored Agarics (Porphyrosporæ) - II4

XXXIX. Agarics with Rust-coloured Spores (Genus Cortinarius) I20

XL. *Brown-spored Agarics (Ochrosporæ) - - - - I25

XLI. Brown-spored Agarics (Ochrosporæ) - - - - I26

XLII. *Pink-spored Agarics (Rhodosporæ) - - - I3I

XLIII. *A Green-spored Agaric, Chlorospora Eyvei (Chlorosporæ) and Gomphidius glutinosus [E. A. Rea] - I36

XLIV. *White-spored Agarics (Leucosporæ) - - - - 136

XLV. Some Leathery and Corky Agarics - _ _ - 138

XLVI. White-spored Agarics (Leucosporæ) - - - - I66

XLVII. *Some Familiar Ascomycetes - _ _ _ - - $\quad$ - 82

XLVIII. *Some Spring Ascomycetes - _ - _ _ - I85

NotE.-The majority of the figures are reduced to one-half the natural size; for the remainder, particulars as to scale accompany the description. 



\section{PART I}

\section{CHAPTER I \\ DEVELOPMENT-THE SPORE, MYCELIUM, AND SPOROPHORE}

THE term "fungi" includes an immense assemblage of I cryptogamic plants, popularly known under the following terms: (I) Mushrooms, applied chiefly to the edible field mushrooms, Agavicus campestris and A. arvensis, and the cultivated form, A. hortensis; (2) Toadstools, agarics other than the preceding, all of which are considered to be poisonous by the great majority of people in this country; (3) Rust, Smut, and Mildew', terms only too well known to farmers, applied to minute species which attack cereals, etc.; (4) Mould, a term commonly applied to minute species infesting various articles of food, ripe fruit, etc., also appearing on damp walls, etc.

The word "mushroom" is probably derived from the Old English maes, a field, and rhum, a knob, which became mushrhum, and finally mushroom. It is also held to be a corruption of the French monceron or mousseron. We usually apply it to the common edible species, $A$. campestris; the French apply it to the St. George mushroom, Tricholoma gambosum. Mycology, as the study of fungi is termed, is a word derived from the Greek mukes, apparently a species of mould, and logos, a discourse.

Fungi are closely related to algæ and lichens. They are descended from the former, and enter into the composition 
of the latter, but differ from both in the entire absence of chlorophyll, or green colouring matter. Lacking chlorophyll, they require organic matter for food, hence flourish as saprophytes on dead organic matter, and as parasites on living organic matter, either plant or animal. They absorb oxygen and give off carbon dioxide, in this respect resembling animals. The curious aberrant group known as the Mycetozoa, or fungus-animals, occupy an anomalous position between the animal and vegetable kingdoms. They approximate more nearly to plants, and at one time found a place in our fungus textbooks.

A fungus is best defined by negative characters. Chlorophyll, as already remarked, is never present; also, there is no system of true tissues. The latter are replaced by threads (hyphæ), which do not fuse organically in a lateral direction, but intertwine instead. These characters must occur simultaneously, otherwise the plant is not a fungus. The importance of this is easily recognised if it be remembered that chlorophyll is absent from some parasitic flowering plants, and that certain algæ consist only of thread-like bodies; but the rank of the former is at once indicated by the system of connective tissues, and of the latter by the presence of green colouring matter.*

It seems hardly necessary to remark that a fungus, no matter where it occurs, is not a de novo production. It is the outcome of a spore (or spores), analogous to a seed in the higher plants, produced by a fungus of the same species, which, finding itself upon a suitable matrix, germinated and reproduced its kind. If spontaneous generation is a fact, as

* Fungi are of great antiquity. Over 400 fossil species have been described. They have been observed in vegetable tissue from rocks of the Carboniferous Age-in some cases so well preserved that details of structure, and even spores, have been made out. These early fungi are chiefly Ascomycetes; gilled and tube-bearing forms have been found in Tertiary strata. 
it is still claimed to be by a few biologists, it has yet to be demonstrated in the fungal kingdom. A germinating spore sends out a minute tube, the germ-tube, simple at first, but which ultimately becomes complex by the formation of lateral branches. The more complex structure is known as hypha. In some of the lower algal-like fungi (Phycomycetes) the hyphæ consist of one continuous simple tube, but with the majority of fungi hyphæ are composed of strings of cells which arise from the continual formation of cross-divisions or septa concurrently with the prolongation of the hypha. In septate hyphæ coalescence of two distinct kinds is not infrequently observed. In the first, hyphæ not at all close together, but growing parallel to one another, form what is known as " $\mathrm{H}$ " connections. From one hypha a lateral branch is thrown out, which fuses with the parallel hypha at the point of contact (Fig. r, B). The second kind is known as clamp connections (Fig. I, A). Contiguous cells of a hypha become connected by a tube which grows out of one and passes into the other,

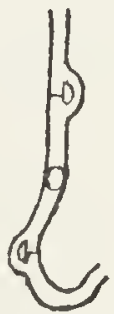

$$
\text { A. } B \text {. }
$$

Fig. I.

A. Clamp connections in hyphæ of Amanita muscaria. B. " $\mathrm{H}$ " connections in hyphæ of $M y$. cena galericulata. absorbing the cell wall at the point of contact. These connections are invariably arranged in a spiral manner round the tube from right to left.

The hyphæ are the vegetative part of a fungus. In the free state they are collectively spoken of as mycelium or spawn.

The mycelium may consist only of a few strands, or may be abundant, as in many parasitic fungi which attack trees, hollowing out their trunks and making them useless for timber. In the majority of agarics the mycelium is probably perennial, producing a crop year by year until the matrix has been completely impoverished of the constituents necessary for its existence. 
The presence of oxalate of lime in the walls of hyphæ probably affords protection against attacks by slugs (many species feed exclusively on non-chlorophyllaceous food); it is especially abundant in the hyphæ of the common Stinkhorn (Phallus impudicus), in which "certain large globose or flask-shaped vesicular cells are almost filled with a radiately crystalline mass of oxalate of lime."

Mycelium is usually white, but is occasionally colourede.g., in Corticium sanguineum it is blood-red; in the little green Elfcup (Peziza annginosa) it is verdigris green, imparting its colour to the wood it infests.

A very thick, hard, cord-like form of mycelium is known as rhizomorph. It was long thought to be an independent fungus. It is associated with many species; the black rhizomorphs of the Honey Agaric (Avmillaria mellea) are perhaps the best known, being of frequent occurrence between the bark and the wood, and about the roots of various trees in a state of decay.

Rhizomorphs are frequently phosphorescent. They may be kept in a dried state for a considerable time, and will afterwards grow afresh if put into water, but the new growth alone will be phosphorescent. Though phosphorescence is chiefly associated with algæ and fungi, it has been observed in all the larger groups of the animal kingdom; also amongst the higher plants-i.e., in a poppy, a lily, and some grasses. The majority of fungi which exhibit the phenomenon are white-spored agarics frequenting dead wood, and occur most abundantly in Australia. In all it is more noticeable at the points of most vigorous growth-i.e., the gills, apex of stem, and margin of pileus. The light given off is bluish in mycelium in rotten wood, and green in some agarics. Worthington Smith has observed phosphorescence in Fomes amosus growing on timber in the Cardiff coal-mines. The miners are well acquainted with it, and say that sufficient light is sometimes emitted "to see the hands by." The 
same observer has noted it in Polyporns sulphuvens. It is said to be not infrequently seen in Corticium caruleum. The phenomenon has not been satisfactorily explained.

Another condition of vegetative mycelium is the peculiar nodules of variable size, at one time classed as a separate genus, Sclevotinm. A dried sclerotium is hard and compact, consisting entirely of interwoven hyphæ covered with a rind of thick brown or blackish cells. Sclerotia contain reserves of food materials utilized sooner or later by the fungi destined to spring from them. Some sclerotia and the fungi associated with them may be seen on Plates IV. and V. The abundant production of rhizomorphs and sclerotia may be compared with the luxuriant growth, without flowers or fruit, of normally flowering plants which sometimes takes place under very favourable conditions.

The spores of larger fungi have no thick outer coat, hence have no protection against extremes of heat and cold. It may be inferred (I) that they germinate immediately upon finding a suitable matrix; (2) that the resulting mycelium has a resting stage; (3) that the duration of the vegetative stage is influenced by climatic conditions. It is almost certain that the mycelium does not produce sporophores if unfavourable conditions prevail at the time of the year when it is normally vigorous. With many species the activity of the mycelium is confined to a certain period. If the fungus is not produced during that time, the mycelium will continue to vegetate, and, given suitable climatic conditions, will carry out its destiny the following year. This is the explanation of the abundance of "mushrooms" in some seasons, and their infrequency or rarity in others. Apart from this compulsory prolonged hibernation, there is a certain amount of evidence tending to show that the mycelium of some species fructifies only once in three years. Records of appearances of fungi in certain spots around Haslemere have been kept at the Haslemere Museum for 
the past ten years, and it is noticeable that certain species -e.g., Boletus piperatus and Hygrophorus calyptraformisappear in three-year cycles, and are not seen in the intervening years.

Whether living in wood or in the earth, the mycelium of some species persists for a very long time. Year after year the sporophores of Fistulina hepatica will appear from a crack in an oak trunk; Xylaria hypoxylon persists for many years on the same stump, and many other instances could be given. There are also some curious records of fungi appearing suddenly in exactly the same spot after a long interval. One of the most remarkable that I am aware of is given by Fries ("Epicrisis," p. 223). He remarks that Hypholoma stovea (a rare species) was found on a decaying part of a living beech trunk in I8I5, and that it appeared from the same crack again in $I 833$.

Cooke and Berkeley observed, concerning Cvatevellus cormucopioides, that "some ten years ago it appeared in one wood at a certain spot by hundreds, whereas during the past three or four years we have failed to find a single species." They also remark: "It is certain that plants found by Dickson, Bolton, and Sowerby have not been detected since, whilst it is not improbable that species common with us may be very rare fifty years hence." As with the higher plants, so is it with fungi-the appearances and disappearances of many are in all probability largely affected by alterations in their environment. Clear away the undergrowth and thin out the trees in a wood that has been carefully and systematically observed during many successive years as regards its flora, and what strange results accrue! To quote an instance that has recently come under my observation: A common near Haslemere was in one part thickly covered with oak and holly, with a sprinkling of beech and birch. Very few wild flowers occurred, and these only at the edge of the thicket. The fungus flora was meagre and without interest, 
excepting that large ascophores of Peziza annginosa often occurred on dead oak branches lying beneath the shade of the hollies. The greater part of the wood was cleared away, leaving only a few trees. Two years later the entire area was thickly carpeted in their seasons with foxglove, ${ }^{*}$ rosebay willow-herb, wood ragwort, and many other plants, including casual aliens not known to occur elsewhere in the district. In the autumn many interesting fungi appeared, including the rare Clavaria fistulosa, several specimens of which were found on decaying birch-twigs. The charred ground on which the woodmen had burnt the refuse bore large blood-red patches of Humaria omphalodes, also other charcoal-loving species.

My attention has been recently directed to the remarkable hardness of the peridium in some specimens of Elaphomyces variegatius (a member of the Truffle family), found by Miss Truda Hutchinson in a wood at Inval, Haslemere, in April, Igog. They were about the size of a marble, and so hard that it was quite impossible to cut them open with a pocket-knife, and a chisel had to be used. The interior was filled with mature spores. It is conceivable that spores so efficiently protected might remain dormant for many years.

The mycelium of some species tends to grow outwards, giving rise in pastures to the well-known dark circles of grass popularly known as "fairy rings," which to this day are a puzzle to many of the old shepherds in Wilts and Dorset, who vouchsafe the explanation, "Zome do say do come by lightnen when do thunder." Berkeley wrote concerning the phenomenon: "It is believed that they originate from a single fungus, whose growth renders the soil imme-

* There is much evidence on record tending to show that the seeds of foxgloves and poppies may germinate after burial for many centuries. It is not without interest to recall in this connection the famous instance of the germination in 1866 of seeds of the Egyptian bean (Nelumbium) from the Sloane Museum collected prior to I753. 
diately beneath unfit for its production. The spawn, however, spreads all round, and in the second year produces a crop, whose spawn spreads again, the soil behind forbidding its return in that direction. Thus the circle is continually increased, and extends indefinitely till some cause intervenes to destroy it. If the spawn does not spread on all sides at first, an arc of a circle only is produced. The manure arising from the dead fungi of the former years makes the grass peculiarly vigorous around, so as to render the circle visible even when there is no external appearance of the fungus, and the contrast is often the stronger from that behind being killed by the old spawn. This mode of growth is far more common than is supposed, and may be observed constantly in our woods, where the spawn can spread only in the soil or amongst the leaves and decaying fragments which cover it." Later writers hold that a single fungus does not usually give rise to the circle in pastures, but that anything which may kill a small patch of grass-e.g., heaps of rotten manure-and thus provide a suitable matrix, may be a cause. The rings sometimes assume enormous dimensions. A heavy dressing of manure tends to break them up. Worthington Smith makes the following interesting observation: "I have known a "fairyring' of Clitocybe geotropa on Dunstable Downs for forty or more years, which, under favourable conditions of light, can be seen at a distance of more than a mile. The diameter has not altered much during the time I have known it, for sometimes it grows inwardly for several years, and then again outwardly."

The mycelium gives rise to the perfect fungus. In the orders with which the present volume deals-the Basidiomycetes and Ascomycetes--it is styled sporophore and ascophore respectively.

In the Basidiomycetes the spores are borne on a clubshaped body, the basidium; in the Ascomycetes they are 


\section{DESCRIPTION OF PLATE II}

\section{DEVELOPMENT IN GASTRONYCETES}

FIG. I. - Capillitium thread of a Bovista. (Very highily magnified.)

Fig. 2. - Tulostoma mammosum: section showing the elongated stem. (Two-thirds natural size.)

FIG. 3.-Basidium and spores of Tulostoma mammosum. (Very highly magnified.)

FIG. 4.-Polysaccum pisocarpium: section showing the numerous cells of the gleba, each containing a peridiolum, and the elongated sterile stem-like base. (One-half natural size.)

FIG. 5.-An jdeal highly enlarged gleba chamber of a Geaster showing the thread-like tissue of its walls, and the basidia bearing, in some cases, four spores.

FIG. 6.-Basidium of a Geaster with its spores. (Very highly magnified.)

FIG. 7.-Sclerodcrma vulgare: section showing the thick peridium surrounding the spore mass; the white flecks amongst the latter are tramal hyphæ. (Half natural size)

FIg. 8.-Basidium and spores of Scleroderma vulgave. (Very highly magnified.)

FIG. 9.-Bisporous basidium of Lycoperdon echinatum. (Very highly magnified).

Fig. Io.-Pedicellate spores of Lysofcrdon cchinatum. (Very highly magnified).

FIG. II.-Geaster vufescens: section showing the almost sessile inner peridium, the thick permanent columella, and the jaggred mouth. (Three-fourths natural size.) 

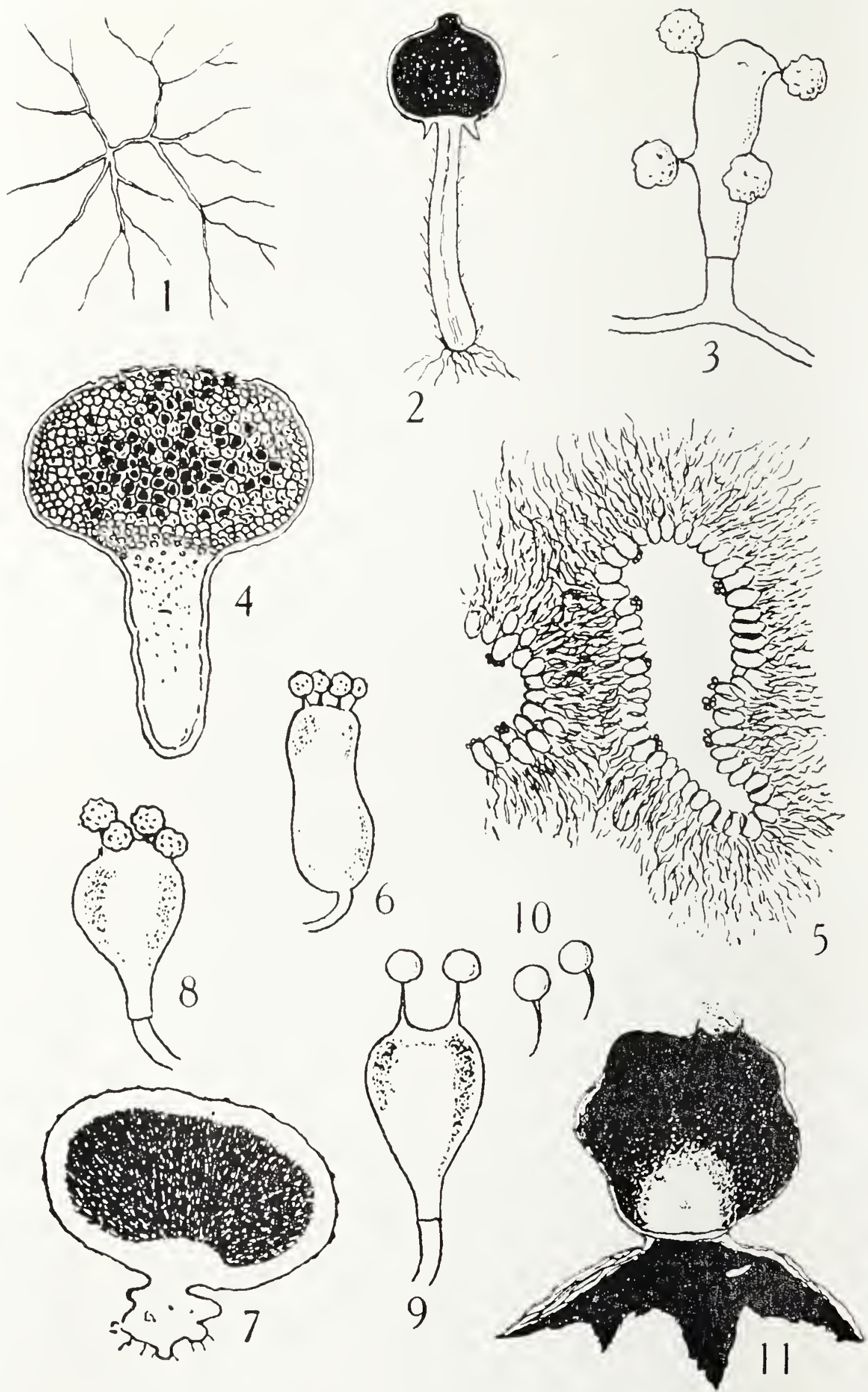
enclosed in a cell known as the ascus. Usually, as shown in the accompanying woodcut, each basidium bears four spores, and each ascus contains eight spores, but there are many exceptions to the rule.

The Basidiomycetes are divided into two very distinct sub-orders - the Gasteromycetes and the Hymenomycetes. In the former the spores are developed within the outer rind or integument of the plant; in the latter they are exposed from the first, or in a very early stage.

The course of development of some typical examples of these primary groups must now be indicated.

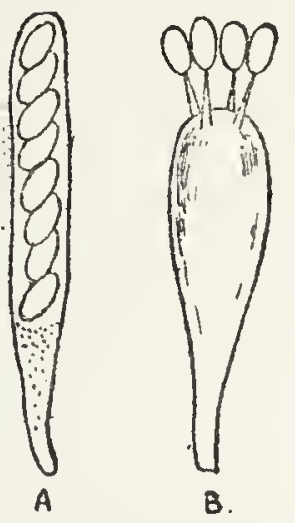

FIG. 2.

A. Ascus containing spores. B. Basidium bearing spores.

\section{GASTEROMYCETES}

A puff-ball is a typical Gasteromycete. In the young state the interior is a pure white, cellular, soft mass, known as the gleba. The thin shell or skin which surrounds it is the peridium. It consists of two distinct layers: a thin outer one-the exoperidium - usually covered with spines, warts, or granules, which flake off in most cases, and disappear as the plant approaches maturity; a thicker inner one-the endoperidium - which either splits regularly at the apex or flakes away when the spores are ripe to allow of their escape. As the gleba ripens it differentiates into a series of minute chambers or cavities, which are narrow, curved, and separated from each other by anastomosing hyphæ. The walls of the chambers consist of layers of branching hyphæ, arranged with their tips pointing inwards. Each hypha bears a basidium carrying the spores-usually four-at its apex. At maturity the tissues of the gleba become moist and dissolve away. In this state the puff-ball 
appears as if water-logged, and has a very powerful and disagreeable smell. The water evaporates, and the peridium is filled with a dusty mass of spores and threads (capillitium). This remarkable deliquescence is observable in many Gasteromycetes. In certain genera, however, the walls of the gleba chambers do not entirely disappear-e.g., in the Birds'-nest fungi they thicken, and each chamber ultimately remains as a little seed-like body, the peridiolum, having its inner cavity lined with basidia and spores.

In some puff-balls the whole of the interior does not become powdery - a thickened cellular portion remains (the stevile base). It may be continued downwards as a stem, or upwards into the spore mass as a hemispherical pillar known as the columella.

The capillitium threads and the spores of puff-balls can be well seen under a microscope with a $\frac{1}{4}$-inch objective. In some species the stalk (sterigma) remains for a long time attached to the spore. Such spores are termed "pedicellate."

The exoperidium in earth-stars (Geaster) consists of three layers: the mycelial (outside), the fibrillose (central), and the fleshy inner layer, or collenchyma.

The mycelial layer is so-called because, in many cases, the threads of mycelium which bind the plant to the soil proceed from it. In some museum specimens (especially $G$. hygrometricus) this layer is absent (it remained attached to the ground when the plant was gathered), and the outer peridium in such appears quite smooth. Generally, however, it remains more or less firmly attached to the middle one. In $G$. fornicatus it forms a cup at the base of the arched segments of the middle layer.

The middle or fibrillose layer is the thickest, and is often the only one present in herbarium specimens. It is very variable. In some species it is strongly hygroscopic. When the plant is moist the segments are reflexed, but they become strongly incurved when dry. This can be easily demon- 

3.0 A. .1.

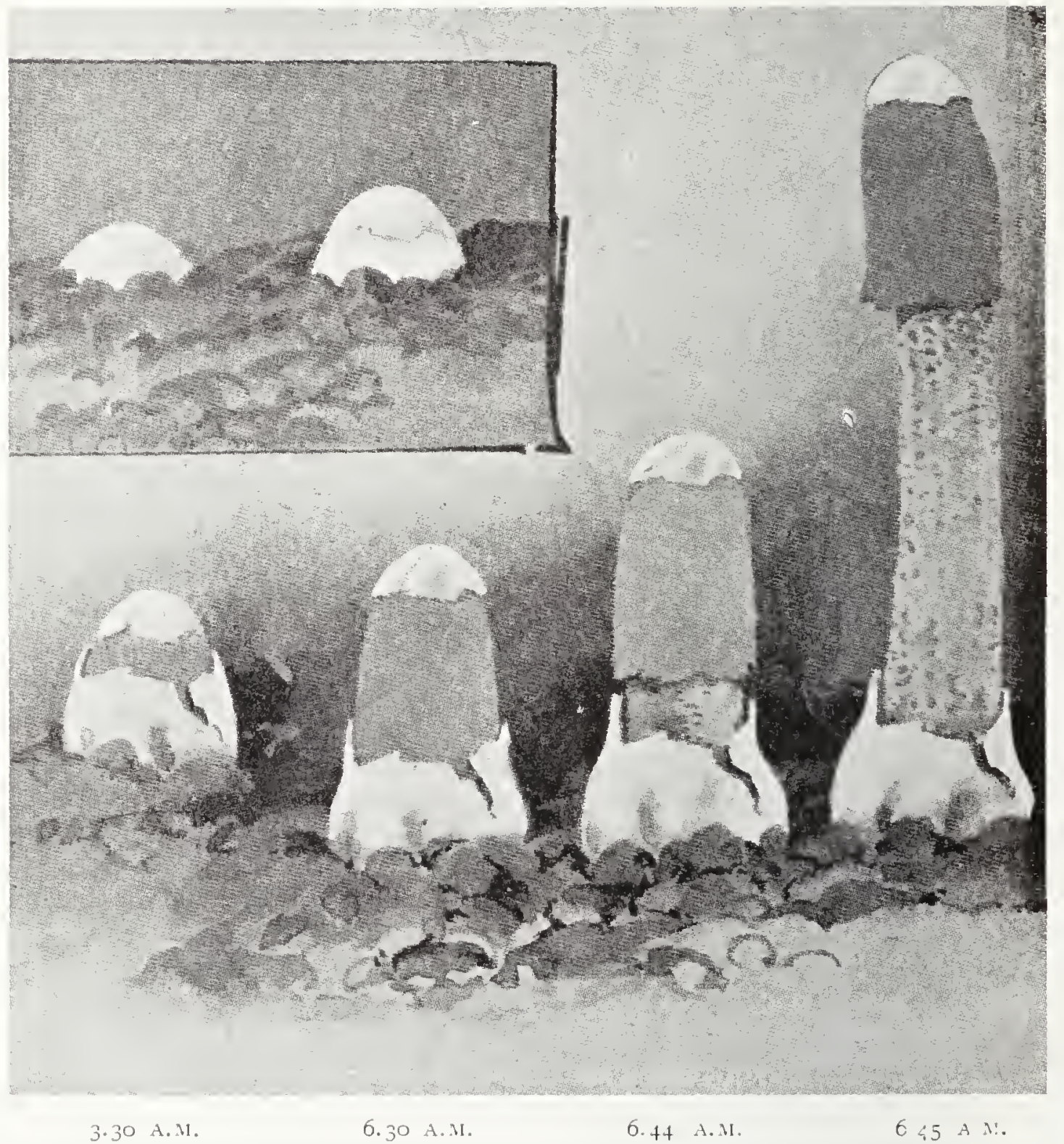

HHALLUS AURANTIACUS, A TROPICAL SPECIES ABOUT THE SIZE OF MUTINUS CANINUS This illustration (copied from Linyl) shezes acry graphicallv the rapidity of grozeth in the Phalloidacene. It avill be observed that the interal betreen the penulimate and last stages is only one minute 
strated by holding a dry plant for a few minutes over steam. It quickly swells out; the segments uncurl and assume a plump, natural appearance, again regaining their former size and position when dry (see Plate XXII.). The inner or fleshy layer is white or pinkish and soft and fleshy at first, but it quickly dries down to a thin, adnate, reddishbrown skin, which often splits up and disappears altogether. In specimens collected early and carefully dried at once it sometimes keeps its colour.

The inner peridium or "ball" of an earth-star is usually of a dull colour, soft and yielding, either stalked or sessile, opening at maturity in various ways to liberate the spores.

In the Stinkhorn fungi (Phalloidaceæ) the spores, enveloped in a fetid gluten, are elevated into the air on a stem-like body, the receptacle. The members of this family are remarkable for their rapidity of growth after emergence from the volvate or "egg" state. This is very graphically shown in Plate III., which originally appeared in a paper by Mr. N. A. Cobb, of Hawaii. Ward observed Phallus impudicus to grow 3 inches in twenty-five minutes, and attain full size (height, 4 inches) in an hour and a half. The remarkable elongation results from the release of the compressed cells of the receptacle (see Plate XXIV., I).

\section{HYMENOMYCE'TES}

Though the representatives of this order lack the protective peridium of the Gasteromycetes, yet it is evident that the necessity for some kind of protection for the spores whilst maturing is very great, and has brought about the development of a protective cap, or pileus. The ultimate objective in each of the families comprising the order has been the production of such a cap with a minimum expenditure of material in providing a maximum hymenial 
surface. In each there are primitive forms of sporophore, consisting only of a layer spread over the surface of the matrix, the spore-bearing surface covering this layer, and acking protection of any kind. (In some cases, however, as when growing on the under side of a log, a certain amount of protection is afforded by the habitat; and in others the presence of oxalate of lime is probably a safeguard against attacks by slugs and insects.) From these simple forms the numerous complicated ones have been evolved.

In one and the same species various types of hymenophore may occasionally be met with. The common Polystictus versicolov affords a very instructive example (see Plate I.). In this species the sporophore is completely adnate when developed on a broad horizontal substratum such as the under surface of a prostrate log (Plate I., 4). When growing from the vertical side of a trunk, however, it is adnate at first, but gradually becomes free at the uppermost margin, and grows away at right angles to the adnate part (Plate I., 5). (A wholly adnate sporophore on the under side of a log will soon develop a free edge if the log is rolled over to such an extent that the fungus is in a vertical position.)

If the fungus develops on a small branch, each end of the free part has a tendency to grow towards the other (Plate I., 7). Sometimes its position-e.g., on the upper surface of a log-allows the recurring ends to meet, and they unite, the result being an umbrella-shaped sporophore with a central stem. The upper part is sterile, and protects the hymenium, which occupies the lower surface, and sometimes the stem also (Plate I., 8).

Polystictus versicolor belongs to the family Polyporaceæ, characterized by the hymenium consisting of closely-packed tubes. This family is the most highly specialized of all Basidiomycetes. The tubes afford an enormous spore- 


\section{DESCRIPTION OF PLATE IV}

\section{DEVELOPMENT IN HYMENOMYCETES}

FIG. I.-Mycelium (a), with early stages of growth (b) of Agaricus campestris. (Natural size.)

FIG. 2.-Section showing the gill-slits. (Natural size.)

Fig. 3.--Section through a young Agaricus campestris, showing the veil enclosing the gills. (Natural sizc.)

FIG. 4.-Adult Agaricus camprstris, showing pileus (c), gills (d), stem $(e)$, ring $(f)$, and mycelium $(g)$. (Three-fourths natural size.)

FIG. 5-Magnified section of a gill, showing the central or tramal layer surrounded by the subhymenial layer, the whole invested by the sp re-bearing surface.

IIG. 6.-Fragment of a gill, very highly magnified, showing trama $(t)$, subhymenial layer $(h)$, basidia $(i)$, with spores $(k)$, sterigmatic $(m)$, and cystidia, or barren basidia $(n)$

Fig. 7.-Sclerotium, with an agaric, Collybia tuberosa, groving from it. (Natural size) 

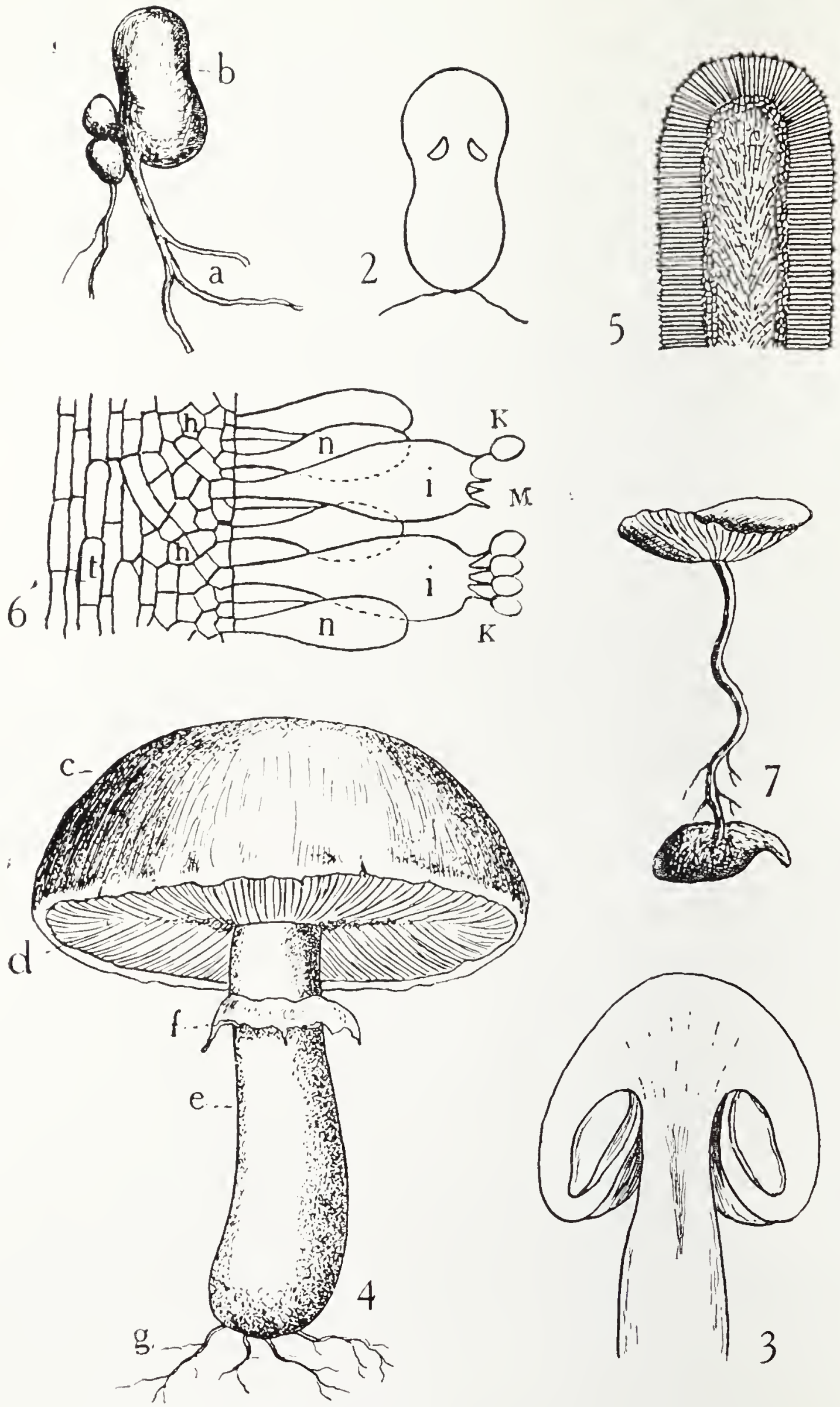

DEVELOPHEST IN HYMENOMYCE"YKS 
bearing surface, also admirable protection for the maturing spores against adverse climatic conditions. Moreover, the entire sporophore is often very hard and woody. (It must, however, be remembered that some species are soft and adnate, with shallow pores or reticulations instead of true tubes.)

The family Agaricaceæ comprises those species in which the hymenial surface consists of radiating plates or gills, developed for the most part beneath a protective cap. Some species are more or less resupinate, and in one remarkable genus, Montagnites (not represented in Britain), the pileus is entirely absent. It frequents the arid deserts of Egypt. The entire plant is at first enclosed in a volva buried in the sand. Within the volva complete development takes place. At maturity the protecting membrane is broken, and the sporophore quickly raised on a tall stem. The spores are liberated from gills which occupy exactly the same position relative to the stem as those of any typical agaric, but are always without a pileus to protect them.

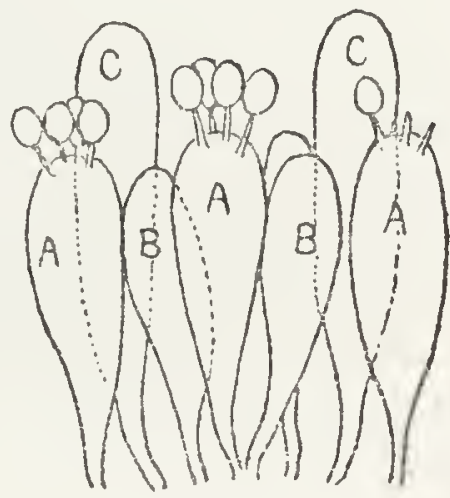

FIG. 3.

From the gill surface of an agaric (highly magnified). A, basidia with spores; B, paraphyses or atrophied basidia; C, cystidia, or hypertrophied basidia.

A gill in transverse section consists of three layers. The central one, or trama, is composed of hyphæ continuous with those of the pileus, and is bounded on each side by the subhymenial layer, on which the hymenium is developed. A gill is in reality a double membrane, folding like a fan around the trama. In the genus Schizophyllum the margin of the gill splits along the line of the trama for a short distance, the split part curling outwards (see Plate XLV.). The surface of the gill membrane in a typical agaric is closely packed with three kinds of club-shaped cells - basidia, paraphyses, and cystidia. 
The basidia are the spore-producing cells. The spores are borne on stalks (sterigmata) at the apex, usually four to each basidium, as in the common mushroom, though this species is frequently incorrectly represented as bearing only two.

The paraphyses are smaller than the basidia, and are always barren. They are probably atrophied basidia, and proceed from the same hyphæ. Their functions are unknown.

The cystidia are large barren cells which project beyond the others. They originate from the hyphæ of the trama, not from the sub-hymenial layer. They are supposed to be hypertrophied basidia. It has been suggested that they serve to keep the gills apart, and to protect the basidia from slugs and insects. They do not occur in all agarics, and are more frequent amongst species with coloured spores.

Some agarics spring from sclerotia.

\section{ASCOMYCETES}

This order includes two sub-orders-Pyrenomycetes and Discomycetes.*

The Pyrenomycetes are characterized by having the ascus-bearing surface always enclosed in a flask-shaped body, the perithecimm, provided with a very short neck, through the mouth of which (the ostiolum) the spores escape.

The perithecia may be isolated (as in Sphæria) or numerous, and imbedded in a fleshy structure, the stroma, their ostiola opening on its surface (well seen in Xylaria polymorpha).

* "As would be expected in such a large assemblage of forms, the two groups closely approach each other at certain points. Genera and even families have from time to time been removed from one sub-order to another, depending on individual opinion" (Massee, "Textbook of Fungi,"'p. 28r). 


\section{DESCRIPTION OF PLATE V}

\section{DEVELOPMENT IN ASCOMYCETES}

FIG. I.-Sclevotinia sclerotionm. Plants of various ages springing from a black sclerotium taken from a cabbage-stalk. (Natural size.)

Fig. 2.-Asci (with eight elliptical spores in each ascus) and paraphyses of the same. (Highly magnified)

FIG. 3.-Leotia lubrica. Plants of various ages. (Natural size.)

FIG. 4.-Asci and paraphyses of the same, highly magnified. Each ascus contains eight-one, two, or three septate spores.

FIg. 5.-Geoglossum glutinosum. (Natural size.)

FIG. 6.-Ascus and paraphyses of the same, very highly magnified. The eight long cylindrical spores are arranged in a bundle at the top of the ascus.

FIG. 7.-A single spore, showing the three septa. (Highly magnified.)

Fig. 8.-Ascobolus furfuraceus. Seven plants. (Natural size.)

FIG. 9.-An ascophore magnified.

FIG. IO.-Section of a magnified ascophore, showing the hymenial surface.

FIG. I I.-Magnified section of a mature expanded ascophore, showing the asci projecting above the level of the disc.

FIG. I2.-Asci and paraphyses of A scobolus furfuraceus. (Highly magnified.) The spores are smooth and hyaline at first, becoming delicately wrinkled and coloured when mature. (After Massee.) 


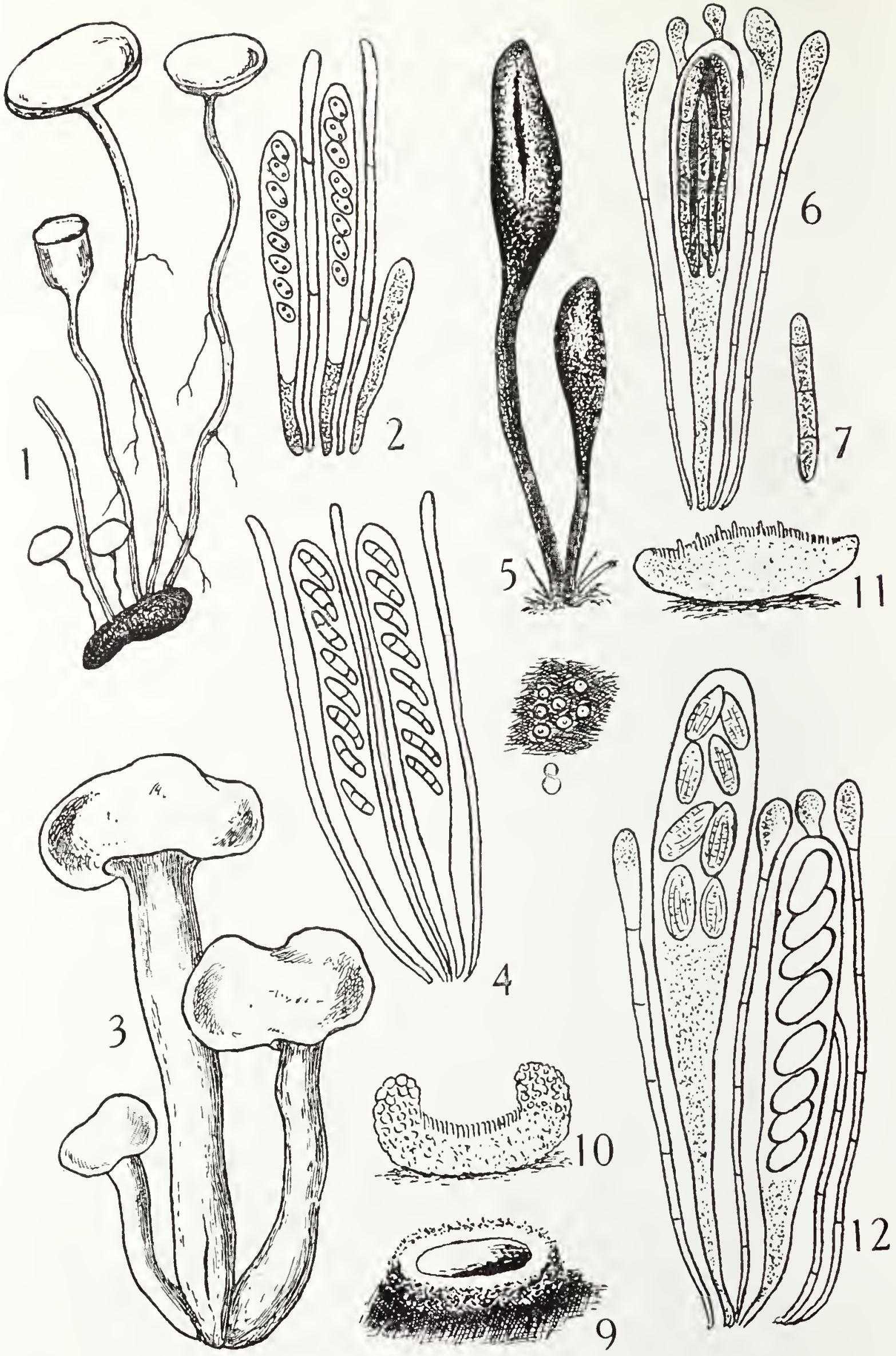


In species not provided with a true mouth the perithecium ruptures irregularly for the spores to escape.

In the Discomycetes the ascus-bearing surface is not enclosed, but is fully exposed at maturity, seated on a flat or cup-shaped ascophore.

The hymenial surface is composed of asci and paraphyses. All the asci are not developed at once. Their apices rarely reach the surface of the hymenium. The longer, slender, and often thread-like paraphyses extend above and protect them. (In a few cases the ascus at maturity is prolonged well above the surface of the disc.) The paraphyses border-

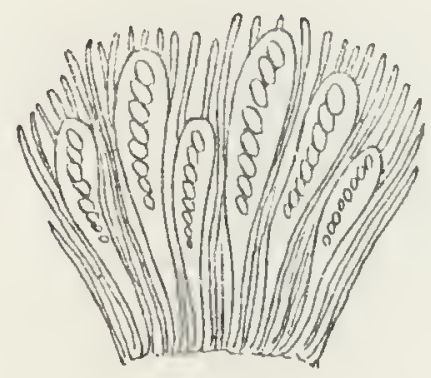

FIG. 4.

Hymenial surface of a Peziza (Discomycetes), showing the slender paraphyses surrounding the asci containing the spores (highly magnified).

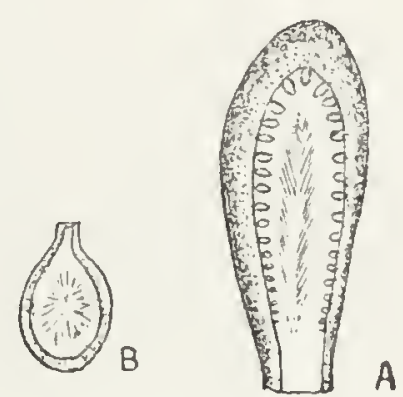

FIG. 5.

A, section through a Xylaria (Pyrenomycetes), showing the numerous perithecia embedded in the stroma, with their mouths opening on to the surface of the fungus ; $B$, a perithecium, mag. nified.

ing an ascus are pushed aside when a spore is being expelled, immediately afterwards regaining their former position. An ascus usually contains eight spores or some multiple of eight. Occasionally there are four spores in an ascus, rarely two, and very rarely one.

The paraphyses vary greatly in shape, being either simple, branched, club-shaped, curved, or curled and contorted. They are developed before the asci. Their sides are gelatinous, and afford a protective and well-lubricated channel, between which the asci thrust themselves. That the paraphyses are abortive asci seems probable, because 
they occasionally enclose one or two spores resembling those normally produced by the fungus. Their tips are often brightly coloured in Discomycetes, causing the brilliant hue of the disc in the cup-shaped species (Pezizæ). They are a continuation of the vegetative hyphæ. Certain species of Peziza are developed from sclerotia, which, as noted above, are a form of vegetative mycelium. They constitute the genus Sclerotinia. 


\section{CHAPTER II}

\section{METHODS OF SPORE DISPERSAL}

THE agencies by which the spores of fungi are dispersed 1 may be arranged under four heads-viz., the Fungus itself, Water, Air, and Animals.

I. By the Fungus itself.-Perhaps the most remarkable instance is afforded by Spharobolus stellatus (a Gasteromy. cete), the catapult fungus, as it might well be called. This species is of frequent occurrence on decaying sticks, sawdust, old sacking, etc. It is inconspicuous, however, and easily overlooked. Before expansion it looks like "little grains of white mustard seed partially covered with a delicate down." It is gregarious, and sometimes occurs in quite large patches. In structure it consists of two layers-a coat and lining, we may call them. The coat is often orange colour; its lining, which is tough, thin, and colourless, forms a cup, in the bottom of which lies the sporangium, a globose brown body containing the spores. At maturity the coat splits half-way down into a few pointed divisions or rays. Soon afterwards the lining is suddenly turned outwards with such force as to shoot out the sporangium like a shot from a catapult. The lining does not leave the coat, being fastened to it at the tips of the rays. Berkeley compared the action to that of a body tossed from a blanket held at the four corners. The sporangium is sticky, and adheres to whatever it may come in contact with during flight.

If a cluster of sporophores are placed under a bell-glass, the sporangia strike the glass with such force as to make an 
audible snicking, and remain adhering to it. The surprising distance to which a sporangium is thrown may be well seen if the sporophores are placed in the middle of a large table covered with white paper.

In Ascobolus and Saccobolus (Ascomycetes which occur on dung in meadows) the ascus is prolonged at maturity above the surface of the disc. In the former each spore in an ascus is surrounded by mucus; in the latter all the spores are held together in a bundle by mucilage. The spores are ejected with considerable force, and adhere to the surrounding grass and herbage, which are browsed by cattle, when they germinate in the alimentary canal, and ultimately produce ascophores on the dung.

Worthington Smith states that the earth-star Geaster Micheliamus, when mature, "will sometimes throw itself elastically some 9 inches from its place of growth."

It has been asserted that some agarics are able to throw their spores to a distance, because it usually happens that the spores are thrown down over a considerable area around specimens confined under a bell-glass or other receptacle. But the statement is open to doubt. Spores, being so very minute, are easily removed a little distance by the slightest air current. I have noticed in such cases that the colour of the spore mass is always more intense in some one direction, at once indicating that an air current was responsible for the phenomenon.

2. By Water. - The sporophores of large woody polypores, etc., growing on trees overhanging rivers and streams may sometimes be carried long distances down the stream. I have noted by experiment that these woody fungi can remain many days in water before they become completely waterlogged.

3. By Aiv. - In the majority of fungi the spores are easily dispersed over wide areas by air currents. The object of the stem, especially in species which grow amongst long 


\section{DESCRIPTION OF PLATE VI}

\section{DISPERSAL OF SPORES}

Fig. I.-The cap of Phallus impudicus, the common Stinkhorn Fungus, with flies devouring the gluten. (Two-thirds natural size.)

FIG. 2.-Spharobolus stellatus, group of plants growing on wood.

Fig. 3.-Yourg plant, magnified.

Fig. 4. - Mature plant about to clischarge the peridiolum.

Fig. 5. - Same after extrusion of the inner membrane.

Fig. 6.-Magnified section of Spharobolns stellatus, showing the peridiolum lying within the cup-shaped receptacle.

FIg. 7:- Sclerderma anlgare (half natural size), showing holes in the cortex made by beetles.

FIG. 8. - Ascus and paraphyses of Saccobolus kervemi, highly magnified (after Nassee), showing the spores arranged in an oblong cluster at the top of the ascus.

Fig. 9.-Fomes annosus growing on larch roots taken from the roof of a rabbit burrow. (One-quarter ratural size.)

FIG. IO.--An agaric with a slug devouring the gills.

Fig. II.-A puff-ball (Lycoperdon). The spines are worn away, the thin peridium is collapsing, and the spores are escaping through an aperture at the summit. 

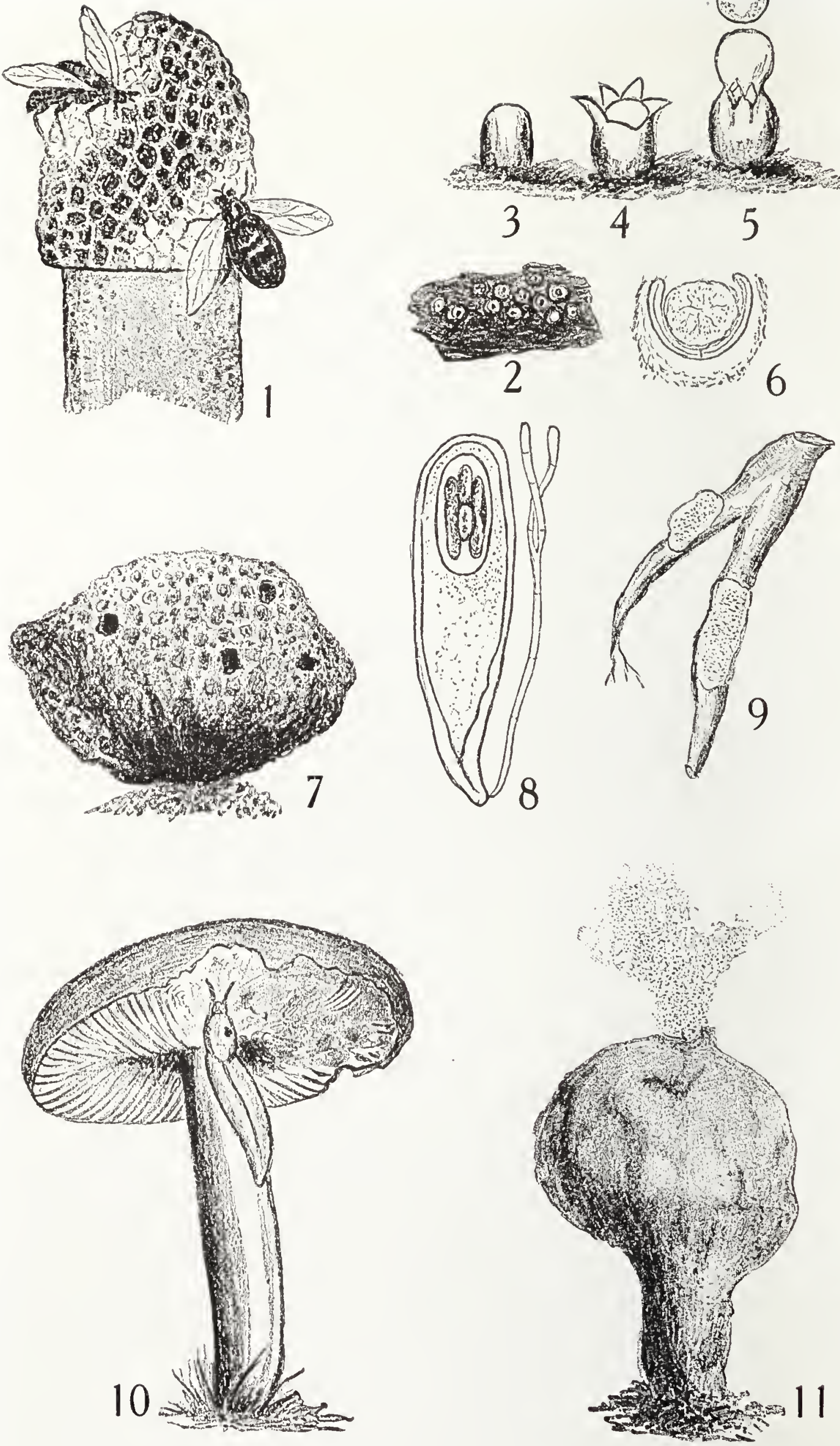
grass, is to raise the hymenial surface well above the surrounding herbage, and thus permit the free passage of air over it.

In the true puff-balls (Lycoperdon) the spores are dispersed by air, consequent upon the collapsing or the flaking away of the soft inner peridium. The sterile stem-like base is firmly fixed to the matrix. The Bovista group of puffballs have no such sterile base, and are not firmly rooted. At maturity the fungus breaks away from the matrix, and rolls long distances before the wind. Lloyd has aptly termed them the "tumblers" of the puff-ball world. (The "cloud" emitted by a ripe puff-ball when squeezed consists of a multitude of spores. It quickly vanishes as the spores separate and float away. If a little of the "dust" is puffed on to a glass slip and viewed under a microscope with a $\frac{1}{4}$ or $\frac{1}{8}$ inch objective, the individual spores may be easily examined.)

In many of the sessile species of Peziza the spores are also discharged in a "cloud." The phenomenon, known as "puffing," often takes place immediately after the fungus is handled or the hymenium is breathed upon. The explanation is that many asci have ruptured simultaneously at their apices through expansion or contraction of their walls, and emitted their spores with a certain amount of force.

4. By Animals. - The dispersal of spores by animal agencies is a subject of the greatest interest.

The spores of the familiar Fomes annosus are carried in the fur of rabbits and other burrowing mammals, which brush against the sporophores often developed on exposed roots of fir-trees in the roof of the burrow. The spores of other deadly parasites are dispersed in a similar way.

Truly subterranean fungi, in which complete development of the spores takes place beneath the ground, are strongsmelling only at maturity. The scent attracts mammals, which dig them up and eat them with avidity. The well- 
known edible truffles are systematically obtained by hunters, who train dogs, and sometimes pigs, to find them. The Wiltshire truffle-hunters (or "trufflers," as they term themselves) assert that squirrels are very fond of these fungi. Berkeley observed that a beetle (Leiodes) attacks the truffle, and "certainly does not improve its flavour." Mr. Alfred Collins, a well-known Wiltshire truffler, writes me: "Some older trufflers have told me the spore is carried about by a small insect known to us as the truffle-beetle. It is a small brown insect, and eats the truffles in holes sometimes almost like a sponge, but whether it is a carrier of the spore or not I don't know." He sent me some of the beetles, which Mr. H. T. G. Watkins has kindly identified as Anistoma cinnamomea (Lciodes cinnamomea). It is highly probable that this beetle plays a far more important part in the distribution of truffles than is at present supposed. The strong smell noticeable in Lentimus cochleatus, Clitocybe odova, and many other agarics, possibly serves as a lure for insects.

It has been noted above that the spores of certain dungloving Discomycetes are dispersed by mammals after they have been ejected upon the surrounding herbage. There is also a certain amount of evidence that the passage of the spore through the alimentary canal of some animal is necessary in some species to insure germination. Berkeley thought that the almost universal distribution of the common edible mushroom "accompanied the introduction of the" horse in various countries." It is well known that mushrooms (i.e., Agaricus arvensis) always appear in fields where horses are regularly kept.

Perhaps the most familiar examples of spore dispersal by insects are afforded by the Phalloidaceæ, or Stinkhorn Fungi. Their spores are immersed in a highly fetid gluten, the whole forming a delectable repast for flies and wasps, whose excrements have been observed to be almost exclusively composed of spores, which, when placed in tubes on sterilised 
earth, germinated at the end of two months, and produced mycelium.

The pileus of the Dog Stinkhorn is red, a colour which probably acts as an additional lure to insects. In some foreign species the pileus is surrounded by a network resembling lace or coral, on which the visiting insects disport themselves.

According to Cooke and Berkeley, the spores of fungi are devoured chiefly by Syrphidæ, flies which also devour pollen.

There is no definite arrangement for spore dispersal in the Sclerodermaceæ, and it seems probable that dispersion is entirely affected by beetles. The thick peridium does not easily rupture, and long before natural decay takes place it is riddled by various beetles. I am told by the Rev. E. N. Bloomfield that Cryptophagus lycoperdi is commonly found in Sclevoderma vulgave.

The mineralised cystidia of some fungi afford a certain amount of protection against visitation by slugs. Their absence in others, and the presence of attractive sugars instead, is suggestive that in these the visits of slugs are desirable, not only for the purpose of disseminating the spores, but also to insure ready germination.

Voglino observed that spores which did not germinate in many media, germinated freely in the liquid contents of the digestive tract of a slug. He also discovered that by collecting slugs from fungi on which they were feeding, and placing them in an enclosed plot of ground, many more species of agarics appeared on this plot the following season than on the adjacent ground.

Slugs, snails, and various insects, are favourite foods of many birds ; * therefore birds indirectly assist in spore dis-

* See an important paper on the "Food of British Birds," by Robert Newstead, in Volume XV. of the Journal of the Board of Agriculture. 
persal, and probably in this way many Continental species are introduced into Britain.

That many species of fungi are brought from one continent to another by human agency-often upon imported seeds and plants-will occur to all my readers. In this way only too many obnoxious kinds have been introduced into this country, chiefly from America, I believe. Massee records that "many kinds of foreign fruit examined at Kew have furnished fungus spores which have germinated readily, and which, if they had found their way to the proper hostplant, would undoubtedly have established a disease." *

"Textbook of Fungi," p. 227. 


\section{DESCRIPTION OF PLATE VII}

\section{COMMON IN FIR WOODS}

I, Canthavellus aurantiacus; 2, ditto, section showing the narrow decurrent gills; 3, Lactarius rufus; 4, ditto, section showing the persistent umbo, decurrent gills, and reddish flesh; 5, Russula drimeia; 6, ditto, section showing the slightly adnexed gills; 7. Tricholoma vutilans; 8, ditto, section showing the yellow flesh and gills; 9, Collybia butyracea; IO, Boletus luteus; II, ditto, section showing the adnate yellow tubes and thick whitish flesh; i2, Collybia esculenta growing from a fir-cone. 


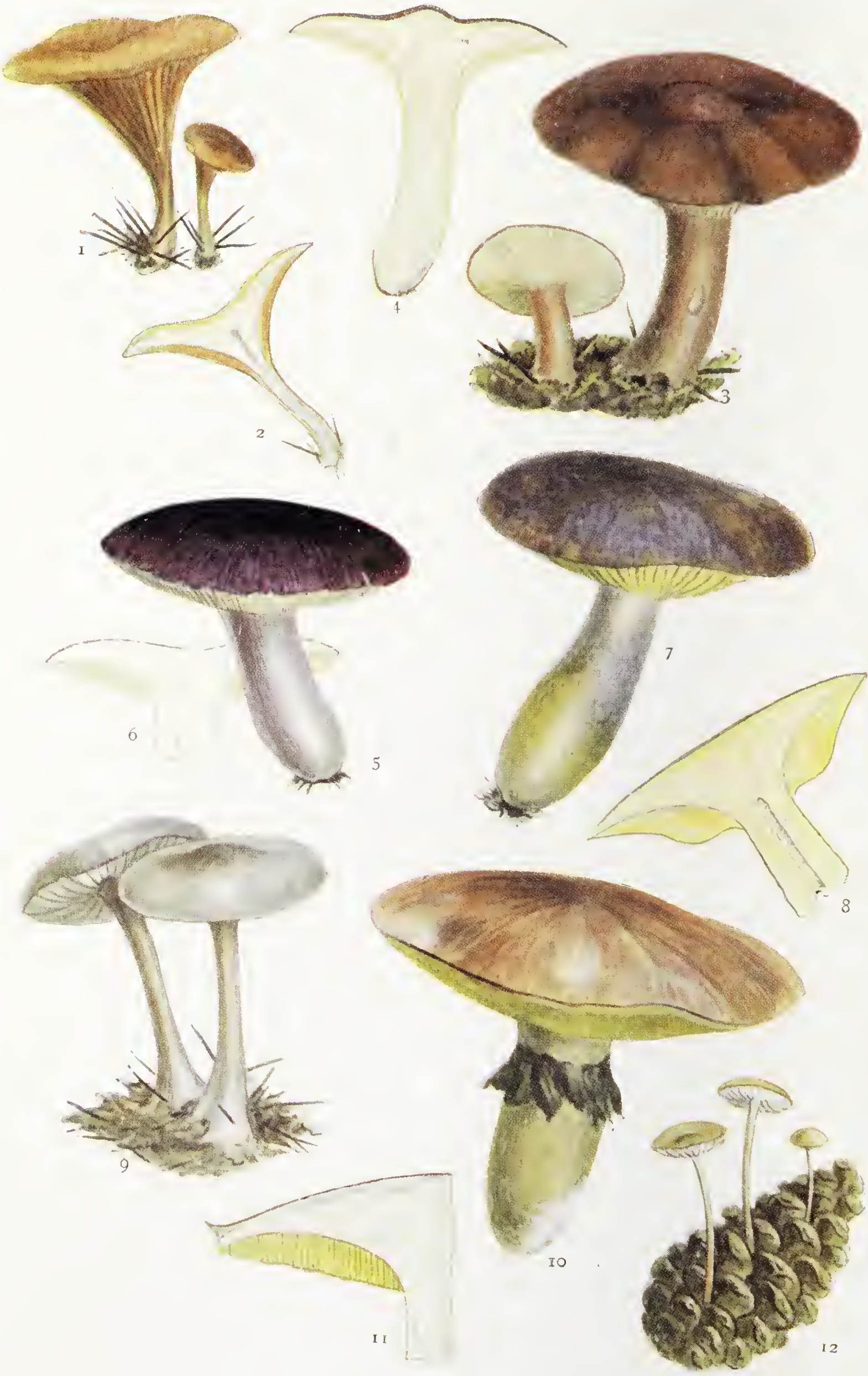




\section{DESCRIPTION OF PLATE VIII}

\section{COMMON IN BEECH WOODS}

I, Collybia dryophila, immature and mature plants; 2, ditto, section showing the almost free gills and hollow stem; 3, Mycena pura; 4, ditto, section showing the adnexed and broadly sinuate gills and hollow stem; 5. Russula emetica; 6, Russula fellea; 7, 8, Marasmius peronatus, young and mature plants; 9 , Tricholoma terveum. 

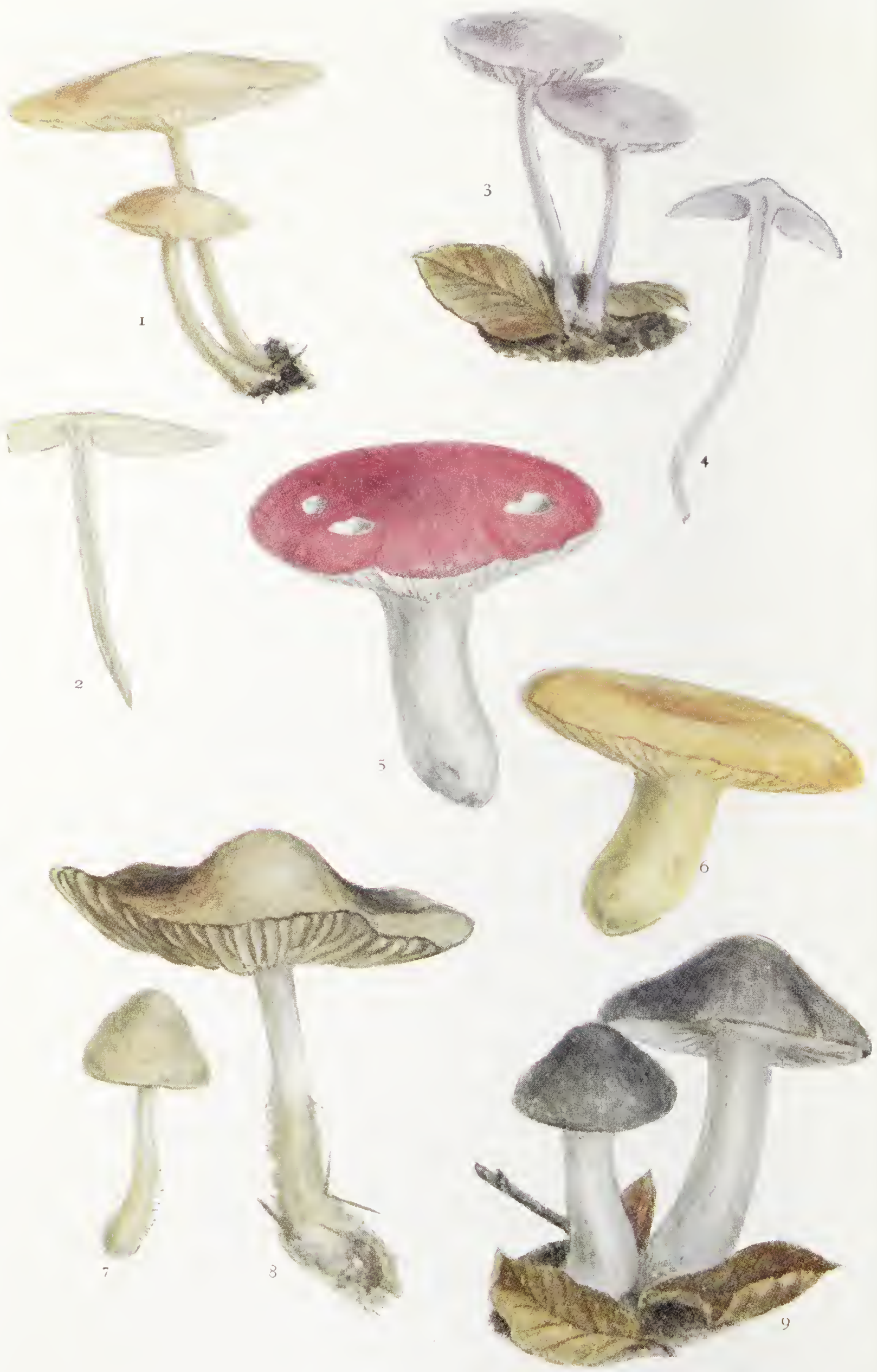


\section{DESCRIPTION OF PLATE IX COMMON IN OPEN PASTURES}

I, Psilocybe fonisecii; 2, ditto, section showing the broad adnate gills; 3. Marasmius oveades; 4, 5, Hygrophorus coccineus, young and mature plants; 6 , ditto, section showing the hollow stem and broadly adnate gills with a decurrent tooth; 7,8 , Hygrophorus psittacinus. plants of various ages; 9. Stropharia semiglobata; I0, ditto, section showing the broadly adnate gills; II, Hygrophorus pratensis; I2, ditto, section showing the decurrent gills; I3. Tricholoma gambosum, mature and very young plants; 14 , ditto, section. 

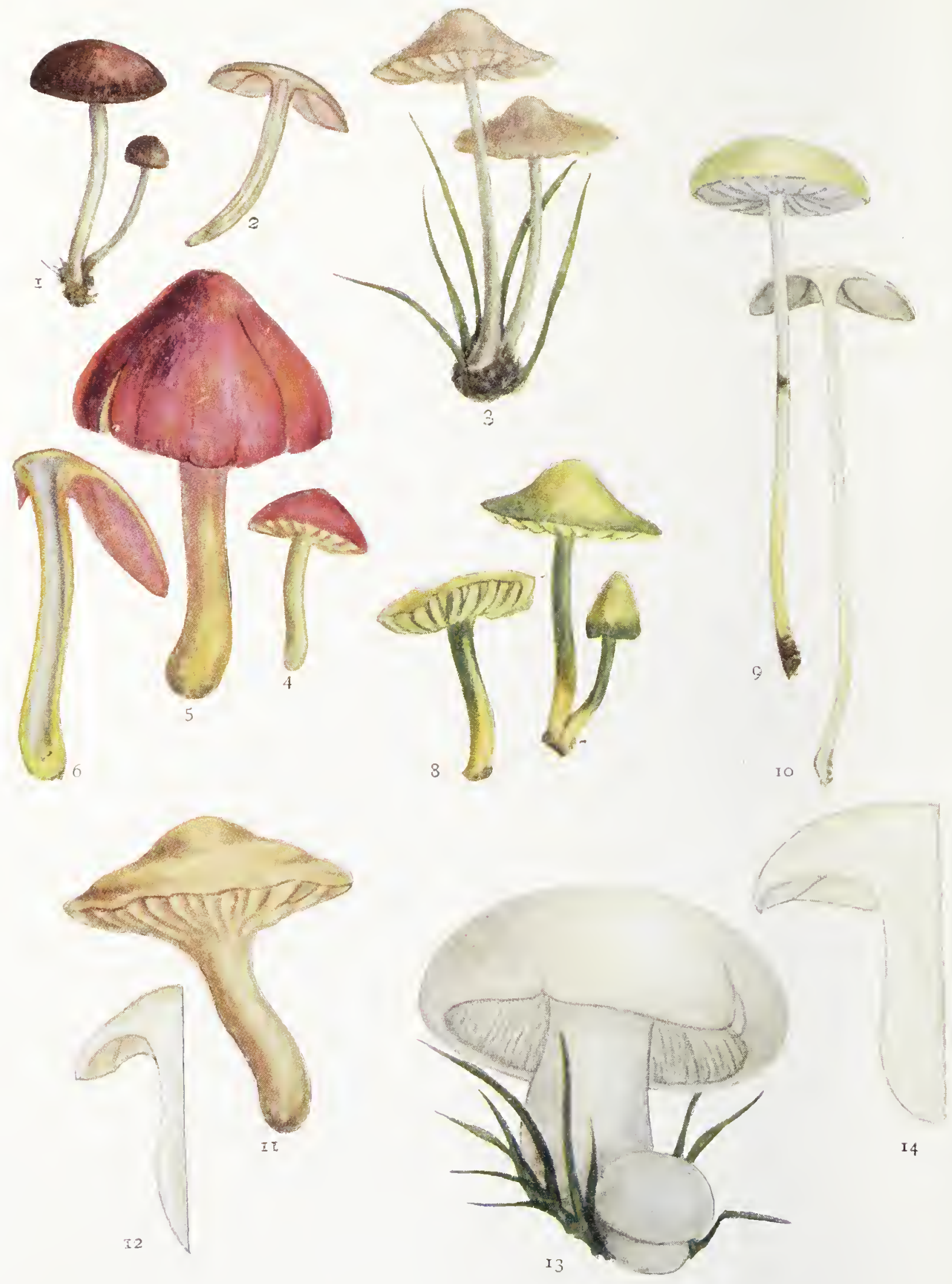


\section{DESCRIPTION OF PLATE $\mathrm{X}$}

\section{SMALL AGARICS OCCURRING $\triangle$ MONGST DEAD LEAVES, ETC.}

I, Marasmius ramealis, half natural size; 2 , Pleurotus hypnophilus, half natural size; 3 , section of the same, natural size ; 4, Mycena cafillaris, half natural size; 5, same, natural size; 6, Marasmius epiphyllus, half natural size ; 7, Marasmius Hudsoni, half natural size ; 8, same, natural size; 9, Marasmins androsaceus, half natural size; Io, Collybia tenacella, half natural size; I I, section of same, natural size: I 2, Mycena vulgaris, half natural size; I3, section of the same, natural size; I4, Collybia conigena, half natural size; I $_{5}$, section of the same, half natural size. 


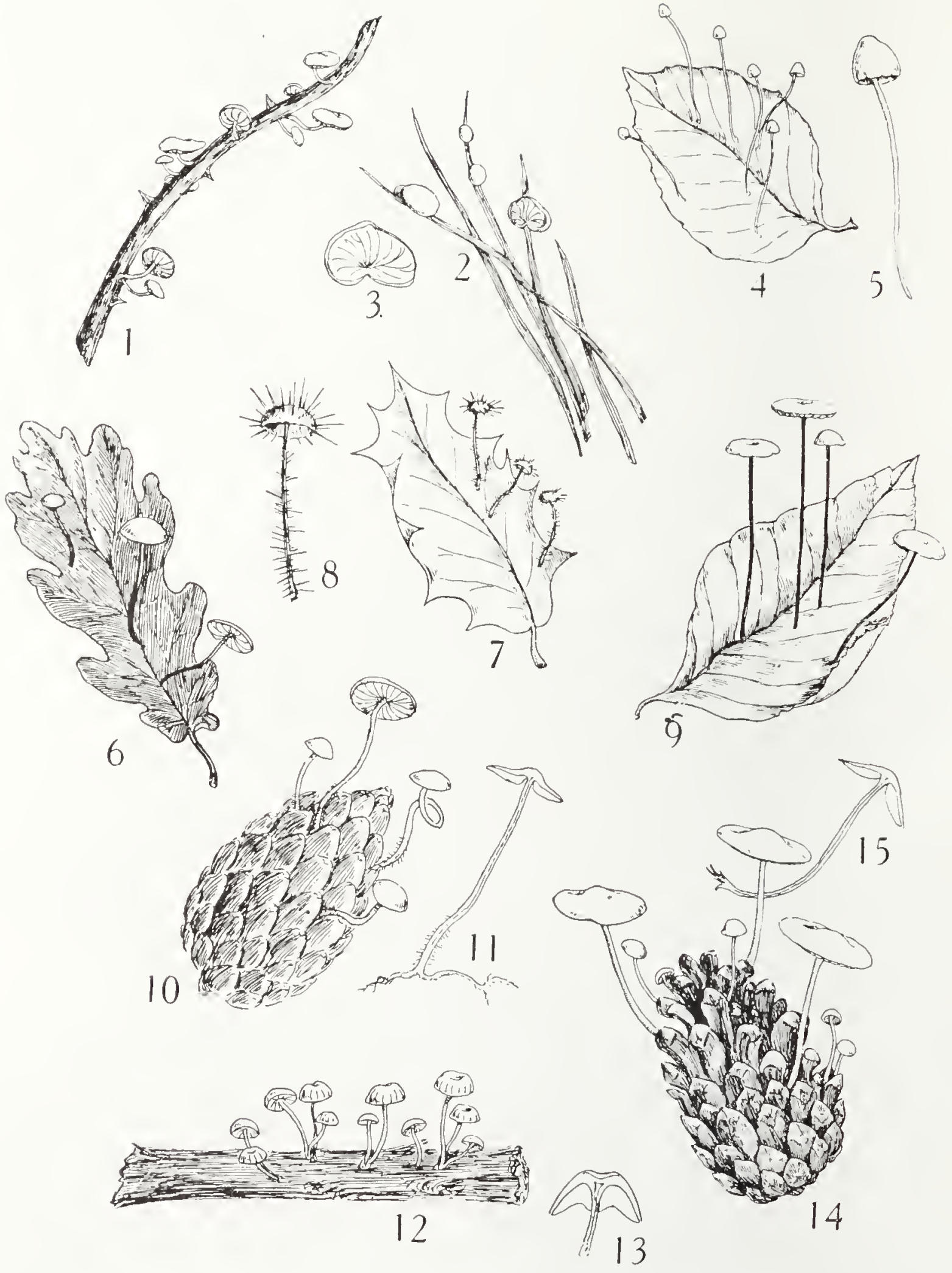




\section{CHAPTER III}

\section{HABITATS}

THE young mycologist will quickly observe that most I fungi, like flowering plants, have their distinctive habitats-e.g., that the fungus flora of a fir wood is largely of a different character from that of a beech wood, and that shade-loving species seldom occur in open pastures. The appended plates indicate a few species characteristic of each of these localities.

Concerning the habitats of agarics, Dr. M. C. Cooke computed that about 64 per cent. are "terrestrial, or nominally so; but we cannot separate those which flourish on old charcoal-beds, on decaying sawdust, or vegetable humus." About 7 per cent. flourish habitually on dead leaves, or on the dead stems of herbaceous plants, and nearly 30 per cent. grow upon decayed wood.

Some agarics chiefly affect the neighbourhood of human habitations. I may instance Coprimus atramentarius, which has on more than one occasion demonstrated very forcibly the extraordinary lifting power of some fungi. A group of sporophores lifted a large mass of asphalt paving in Hampton Road in I889; a similar occurrence took place at Dunstable in I899.

Merulius lacrymans, the "dry-rot" fungus, is essentially a domesticated species, if the term may be allowed, occurring only on worked wood in houses, ships, etc.

Plate $\mathrm{X}$. depicts certain small agarics with distinctive habitats, but it must be observed that a species occasionally 
elects to flourish on a matrix very different from that on which it usually occurs. A very curious case in illustration of this was the discovery of Lachnea sublivida (first British record) by Mr. Charles Crossland on a very thin layer of black dust covering some pig-iron in a foundry at Hebden Bridge, Yorkshire, its usual habitat being damp soil.

There are old records of fungi occurring on iron which had been red hot only a few hours previously. It is possible that these concern species of Mycetozoa which had migrated to the iron soon after it had cooled.

Dr. Plowright once found Pleuvotus ostreatus growing on dry cerebral matter in the skull of a stranded whale on the Norfolk coast.

Peculiarities of environment sometimes totally change the appearance of a species, and produce a monstrosity. Absence

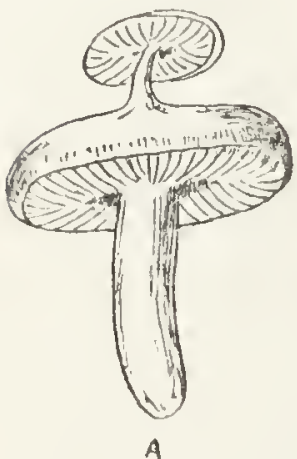

FIG. 6.

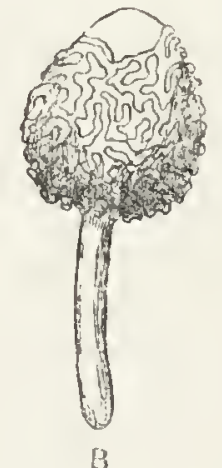

B

A, An agaric with secondary pileus; B, Clitocybe laccata-monstro. sity "tortilis." of light is one of these. Certain Hymenomycetes assume most grotesque shapes when growing on timber in mines-e.g., Lentimus tigrimus and Polyporus squamosus in such situations occasionally resemble the branched antlers of a deer.

Abnormal growths, the causes of which are unknown, are not at all uncommon. Fig. 6, B, depicts the monstrosity "tortilis," of Clitocybe laccata. The pileus forms a closed ball, on the greater part of which the gills form an anastomosing network.

The innate tendency amongst certain Hymenomycetes to secure a protected hymenium has been already alluded to. It may also be seen in species which, through accident of position in youth, find themselves growing stalk uppermost. I once found a specimen of Hydmum repandum growing head 


\section{DESCRIPTION OF PLATE XI}

\section{LARGE FUNGI PARASITIC ON OTHERS}

I, Nyctalis asterofhora growing on Russula Migricans; 2, ditto, section showing the narrow adnate gills; 3, Nyctalis parasitica growing on Russula adusta; 4, ditto, section showing the broad adnate gills; 5. Boletus parasiticus growing on Sclcrodcrma vulgare; 6, ditto, section showing the subdecurrent tubes; 7, Volvaria Loveiamus parasitic on Clitocybe ncbularis; 8 , ditto, section showing the free edge of the volva and the free gills; 9, ditto, section of an unexpanded plant, showing the gill-slits. 


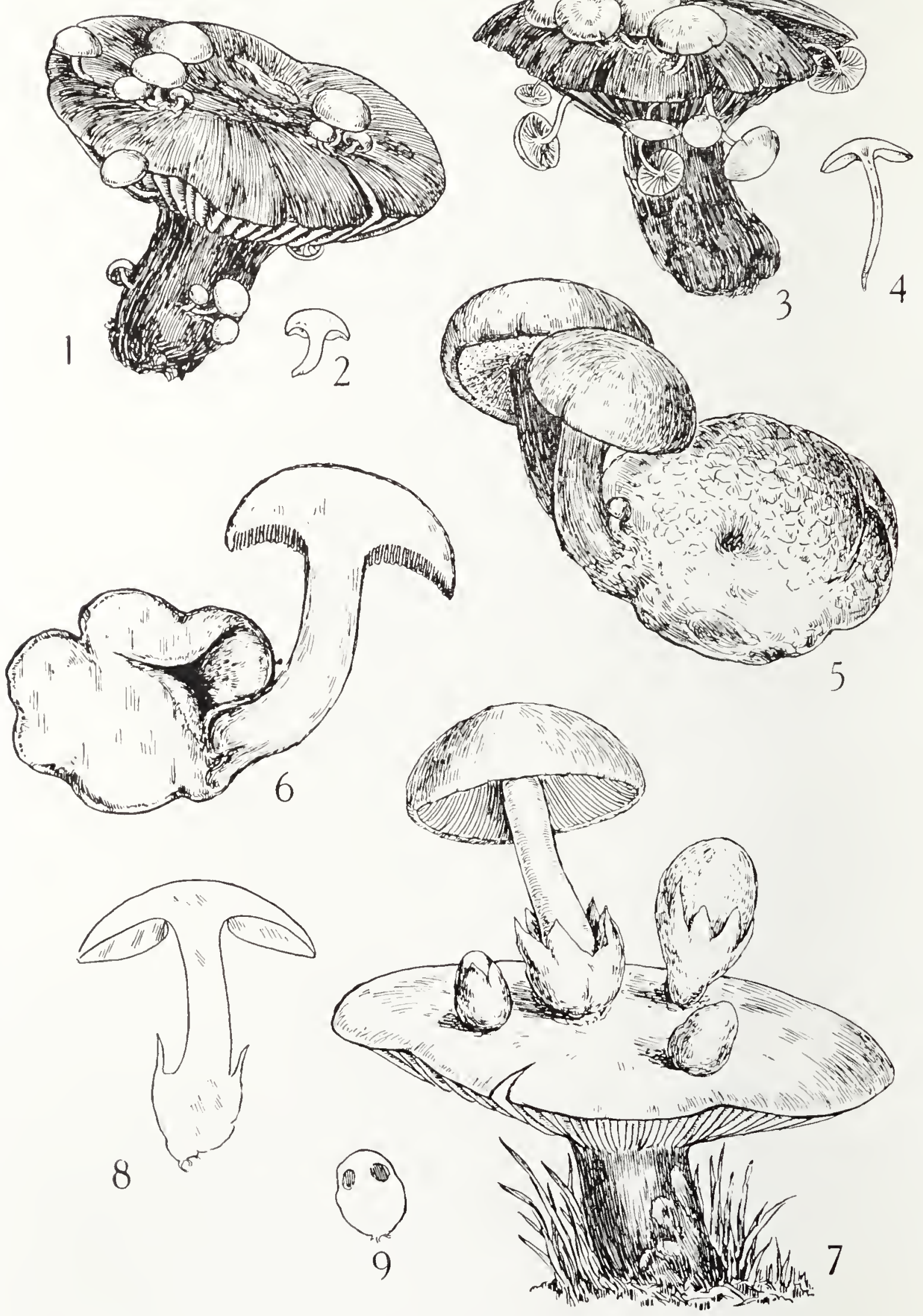


downwards in an overhanging bank. All the normally placed spines were pointing downwards, and a hymenial surface with well-developed spines occupied the greater part of the centre of the true pileus.

Agarics with resupinate pileoli growing on the pileus, usually at the margin, are not infrequently met with. Examples with stalked secondary pilei also occur (Fig. 6, A). These latter must not be confounded with parasitic species, examples of which are shown on Plate XI., where also is depicted the curious Boletus parasiticus, which lives a parasitic life on the common earth-ball.

The late Professor Marshall Ward pointed out in a very valuable paper on the "Nutrition of Fungi"* that more accurate information is wanted respecting the habitats of fungi. "It is important to know not only whether the substratum is charcoal, burnt clay, sand, etc., but if the mycelium in open land runs into manure, humus, or even to the living roots of grasses, etc. Much has been accomplished, but more can be done by further observation in the field to direct the efforts of those who cultivate the forms with a view to settling these questions, and we must all admit that it is a branch of science that opens up splendid opportunities for research. We should like to see more information regarding the shade-bearing, moisture-loving, wind-enduring, and frost-resisting capacities of groups of critical and closely allied species, as well as statistics regarding season, altitude, habitat, etc., recorded with all the care and completeness possible. ... Is there any connection between the habitat and nutrition of the species and their specific and generic character-e.g., colour of spores, texture of pileus, hollow or stuffed stipes, adhesion, freedom, etc., of lamellæ, or minor characters of colour, silkiness, etc. ? Can we find in the distribution of the species in

* Transactions of the British Mycological Society, vol. i., pp. I24I 42 . 
latitude or altitude any explanation of the variation which it is admitted occurs within the limits of accepted species?"

He thought it probable that different specific names have been given to the same fungus growing on different media or under different conditions. 


\section{CHAPTER IV}

\section{SAPROPHYTES AND PARASITES}

FUNGI deriving their nutriment from dead organic 1 matter, such as dead leaves, wood, etc., are termed saprophytes; those which obtain their food from living plants and animals are known as parasites. Some species are able to accommodate themselves to either kind of diet.

A spore from a parasitic fungus may germinate on whatever it happens eventually to settle upon, but unless it does so on the host (or hosts) it particularly affects it will produce only a germ tube, and then die. There is something in the cells of its true host that it is specially fond of, something which attracts the germ tube and causes it to enter. Hence we understand why it is that a fungus producing myriads of spores is rare or uncommon. Perhaps only one spore in several millions germinates under favourable conditions and produces mycelium; all the others, owing to unfavourable environment, die soon after germination.

It has been demonstrated that a parasitic fungus can be induced to enter the leaves of a plant which is not its true host, and there produce its spores, by injecting the leaves with a substance much liked by the parasite. If the spores produced under these conditions are in turn sown upon other injected leaves, and the process continued for many generations, it will be found that the twenty-fifth generation (or thereabouts) is able to enter leaves that have not been injected with the attractive substance. The parasite has been gradually educated to feed upon and thrive on the 
special substance normally present in the cells of the njected plant.

By experiments of this kind true saprophytes have been transformed into parasites, showing that parasitism is an acquired habit.

I am not acquainted with any statistics giving the annual loss to foresters through the ravages of parasitic fungi; it must be very great. Prussia is said to have lost more than $£ 20,000,000$ in the year I89I through an epidemic of grain rust. The United States Department of Agriculture stated that the losses in 1897 through injury caused by fungi amounted to about $\mathcal{E} 40,000,000$. This enormous sum probably includes damage to forests as well as to cereals and fruit.

One of the commonest of our native fungi, and a deadly enemy of conifers, Fomes amnosis, forms the subject of Plate XII. It is a perennial, depositing a new stratum of tubes every year over the old ones (Plate XII., 2), which die and become very hard. These are best seen in large sporophores growing out of erect trunks (Plate XII., I). It encrusts anything with which it may come into contact, and often occurs with leaves and twigs embedded in it. I have a sporophore which was found with a living shell (Helix rotundata) protruding from, but firmly fixed to, the hymenial surface. When growing on roots it is often quite adnate (Plate XII., 6). It frequently appears in this state on roots exposed in rabbit burrows; the spores fall upon the fur of the passing mammals, and are brushed upon the roots of other trees. The hyphæ enter between the bark of the root, and form a white felt of mycelium, which creeps upwards into the trunk, appearing like little white balls through any cracks which may occur in the root bark (Plate XII., 3). The mycelium slowly spreads up the middle of the stem, destroying its tissues and hollowing it out like a pipe. Plate XII., 5 depicts the section of a 


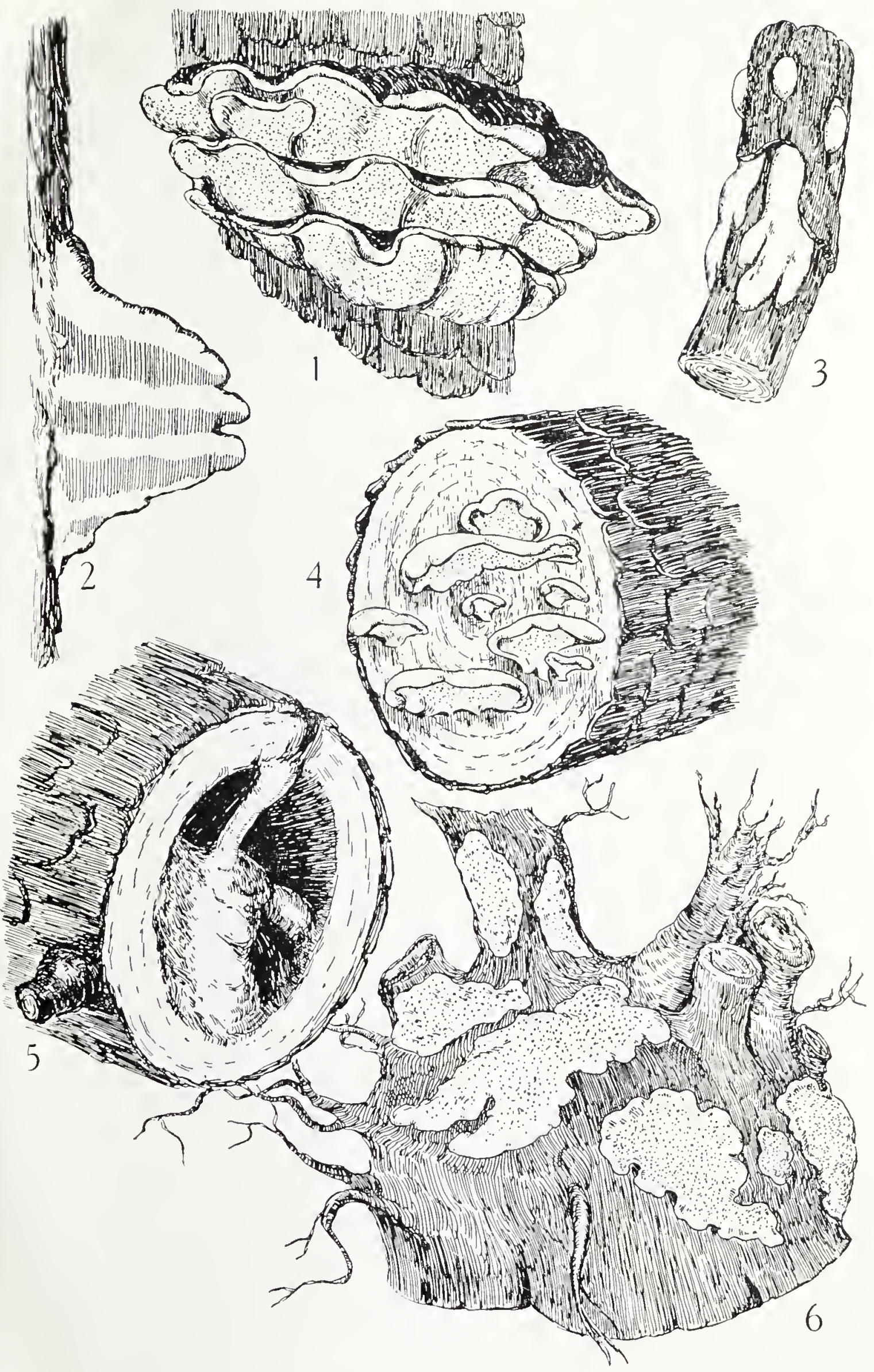




\section{DESCRIPTION OF PLATE XII}

FOMES ANNOSUS

FIG, I.--Perennial sporophores on a fir trunk.

FIC. 2.-Ditto, section, showing the strata of tubes.

FIG. 3.-Hyphæ creeping beneath bark.

FIG. 4.-Sporophores on cut surface of a $\log$.

FIC. 5.-Section of an attacked trunk.

FIG. 6.-Adnate sporophore on stump of a Scotch fir: 
tree in this state. It will be noticed that the enclosed branches are not attacked, the mycelium preferring the easier task of destroying the softer tissues.

Hartig says the mycelium does not pass up into the trunk of the Scotch pine, being kept back by the abundant resin present in the lower part of the stem in these trees. Its presence in a stem in the early stage of attack can only be demonstrated by microscopic examination, and is often present when least suspected. A large number of sections of trunks of young Austrian pine and Norway spruce were stacked against the inner wall of my wood-shed in March, 1908. Each section was about a foot long, and all were placed in such a manner that only one end was exposed to the light. The trees when felled appeared to be quite healthy. No notice, however, was taken of their roots; they were felled by woodmen in the ordinary course of thinning out a plantation. Early in the following November it was observed that many of the sections had developed pileate sporophores, in all cases only upon the end exposed to the light. The appearance presented by one of them is shown in Plate XII., 4.

There comes a time when an attacked tree shows external signs of disease, chiefly indicated by the foliage becoming pale, but many years may elapse before this takes place. A large and apparently very healthy an vigorous spruce growing within a few hundred yards of the Haslemere Museum was struck by lightning, and a large piece torn away from the side of the trunk. To the astonishment of all who saw it, this tree was completely hollow, and must have been attacked by the parasite many years previously.

A tree very quickly dies after the foliage has commenced to change colour, and examination always reveals a plentiful crop of sporophores on the roots. Plate XII., 6 shows an inverted stump of a Scotch pine with numerous resupinate 
sporophores upon it. Diseased trees should be removed, and their roots dug up and burnt.

Five other well-known hymenomycetal parasites are delineated on Plate XIII.:

FIG. I. Amillaria mellea, the Honey Agaric.-It is one of the commonest of "toadstools" and one of the greatest of fungus pests; it attacks all kinds of trees, in garden and orchard as well as forest. It invades the roots of its host, spreads up into the cambium layer, and soon brings about its death. If, on stripping away the bark from a sickly tree, there is found beneath it an abundance of shining black cords of varying thickness (Fig. 2), then it is pretty certain that Armillaria mellea is at work, even if no sporophores occur. These black cords (vhizomorphs) spread from tree to tree. Infection may also take place by spores settling upon a wound-e.g., a lopped-off bough or partly exposed root damaged by spade or cart-wheel. Wounds in fruit-trees should be at once protected by painting the surface with tar.

FIG. 3. Armillaria mucida. - It attacks living beeches. The beautiful shining white sporophores are of common occurrence in beech woods in autumn.

FIG. 4. Pholiota adiposa.-It is usually a saprophyte, but sometimes attacks living conifers, beech, plum, etc., entering by an abraded surface. Fig. 5 is a section of a young specimen, showing the veil extending as a membrane from the margin of the pileus to the stem.

FIG. 6. Polyponus Schweinitzii.-It attacks many conifers, obtaining entrance in the same way as Fomes annosus. It hollows out the trunk, and is probably the most dangerous enemy of the larch, for which it has a decided preference: Remembering that the larch is the only conifer that really pays well in this country for planting, the mischief done annually by this fungus must be very great. It is increasing rapidly in the South of England, where nothing seems to be done to check its progress. It is now tolerably abundant in 


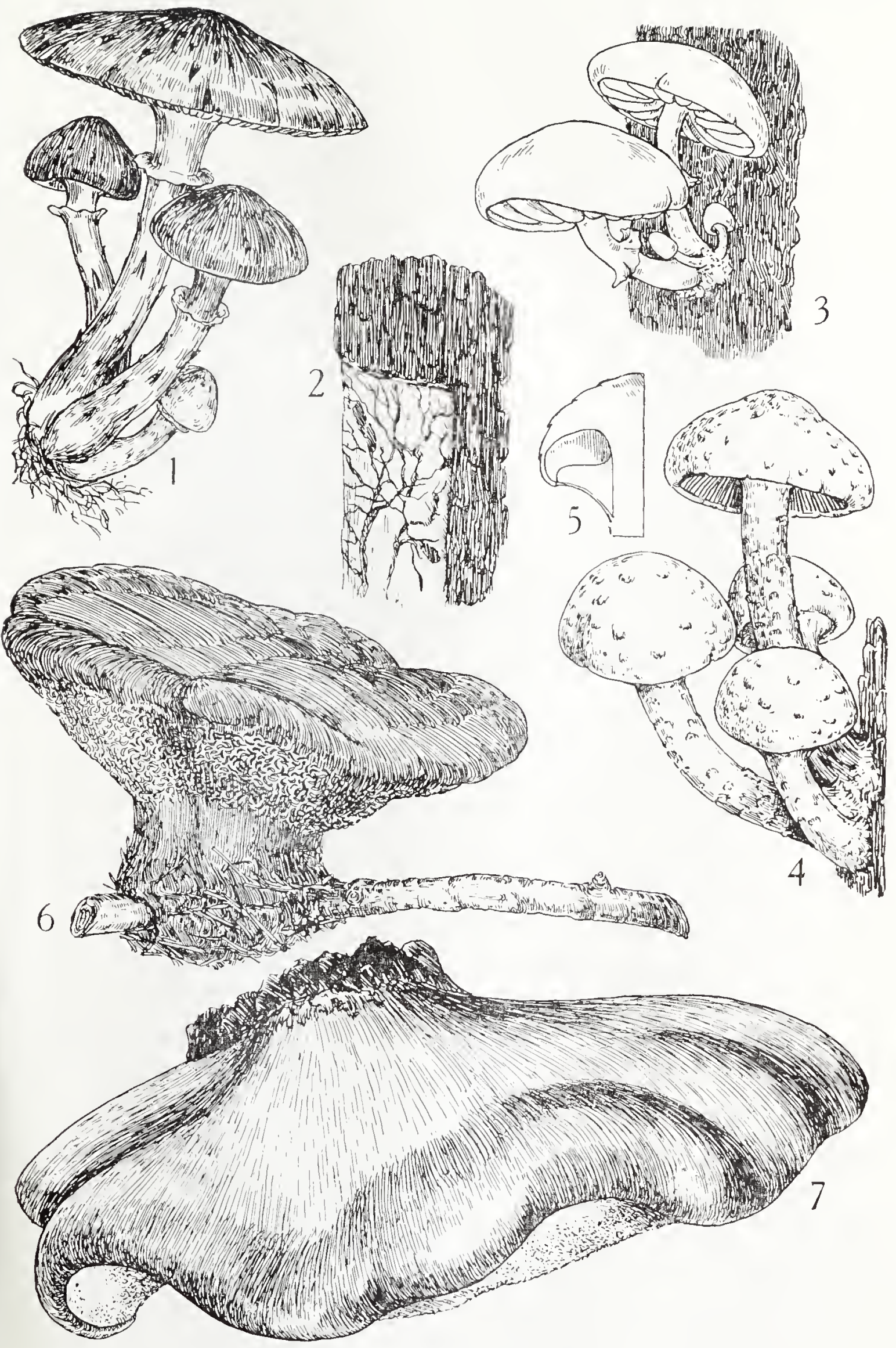




\section{DESCRIPTION OF PLATE XIII}

\section{DESTRUCTIVE TO LIVING TREES}

FIG. I.-Armillaria mellca.

FIG. 2.-Rhizomorphs of Armillaria mcllea.

FIG. 3.-Amillaria mucida.

Fig. 4.-Pholiota adiposa.

Fig. 5--Ditto, section.

Fig. 6.--Polyporus Schweinitzii.

Fis. 7.-Polyporus betulinus. 
woods around Haslemere, where there was not a trace of it ten years ago.

FIG. 7. Polyporus betulimus. - Though usually associated with dead birches, on which its large sporophores form very artistic objects, this species also attacks living trees, its presence being indicated by the brown discoloration of the wood. It is an annual; the mycelium is probably perennial in the wood.

Additional parasites figured on our plates are:

Stercum hirsutum (Plate I.), which attacks various living trees, and is said to be the cause of "fly" wood and "yellow and white piped" wood.

Fomes fomentarius (Plate XXXIII.) attacks beech and oak, and is said by Hartig to be the cause of the "white rot."

Polyporus sulphureus (Plate XXXIII.) attacks oak, larch, poplar, willow, yew, etc.

Polyporus squamosus (Plate XXXIII.) infests many of our native trees, notably the elm.

Hirneola auricula-jude, the "Jew's ear" (Plate XXVI.), attacks living elder.

Merulius lacrymans, the "dry rot" (Plate XXXII.), is one of the most destructive of parasites. Too often does the purchaser of a newly-built house make its acquaintance, the first indication of its unwelcome presence usually being a streak or film of reddish-brown "dust " coming from a crack in the floor, often within an ill-ventilated cupboard. The "dust" is its spores, myriads of them. If the floor is not quickly taken up by the owner, it will soon be eaten up by the fungus. Rotting wood should be removed, and what appears to be sound should be carefully disinfected with creosote. The presence of the mycelium of the fungus in wood is easily known by the "red stripe," and it is regrettable that builders constantly use such wood for building purposes without thoroughly disinfecting it.

Fistulina hepatica (Plate XV.).-The "beefsteak" grows 
on living oaks, and, according to Hartig, causes a deep redbrown decomposition of the wood.

Dadalea quevcina (Plate XXXII.) also attacks living oaks.

Six leaf parasites are shown on Plate XIV.:

FIG. I. Exobasidium vaccinii.-A true Basidiomycete nearly allied to Corticium. It forms orbicular swellings on living leaves of the whortleberry (Vaccinium myrtillus), rarely on the leaf-stalks and stems. The flesh-coloured hymenium protrudes from the under surface of the leaf; the opposing upper surface is red or purple.

FIG. 2. Rhytisma acerinum, an Ascomycete, causes the familiar black spots on sycamore and maple leaves. The ascophores mature in spring after the leaves have been lying on the ground throughout the winter. If a spore settles on a young leaf the hyphæ enter the tissues, causing yellowish spots to appear in June. These change in July to pitchblack. The leaves on autumnal shoots remain free of disease, and do not fall so quickly as infected ones. This pest is checked by carefully sweeping up and burning diseased leaves.

FIG. 3. Rhytisma punctatum superficially resembles the preceding, but the spot consists of closely crowded punctate, not continuous, spots. The black spots frequently seen on willows are caused by $R$. salicimm.

FIG. 4. Ascomyces pruni* causes the young fruit of cultivated plums, also bullace, sloe, and wild cherry, to become deformed and swollen, assuming the condition known as "pocket plums" or "bladder plums." The mycelium is perennial, spreading in spring through the young shoots, its fruit appearing as a delicate whitish bloom in July. It does not spread backwards on a branch, hence may be arrested by hard pruning.

FIG. 5. Ascomyces deformans causes the well-known leaf curl of peach and almond, now universally distributed and very

* Ascomyces is synonymous with Exoascus. 


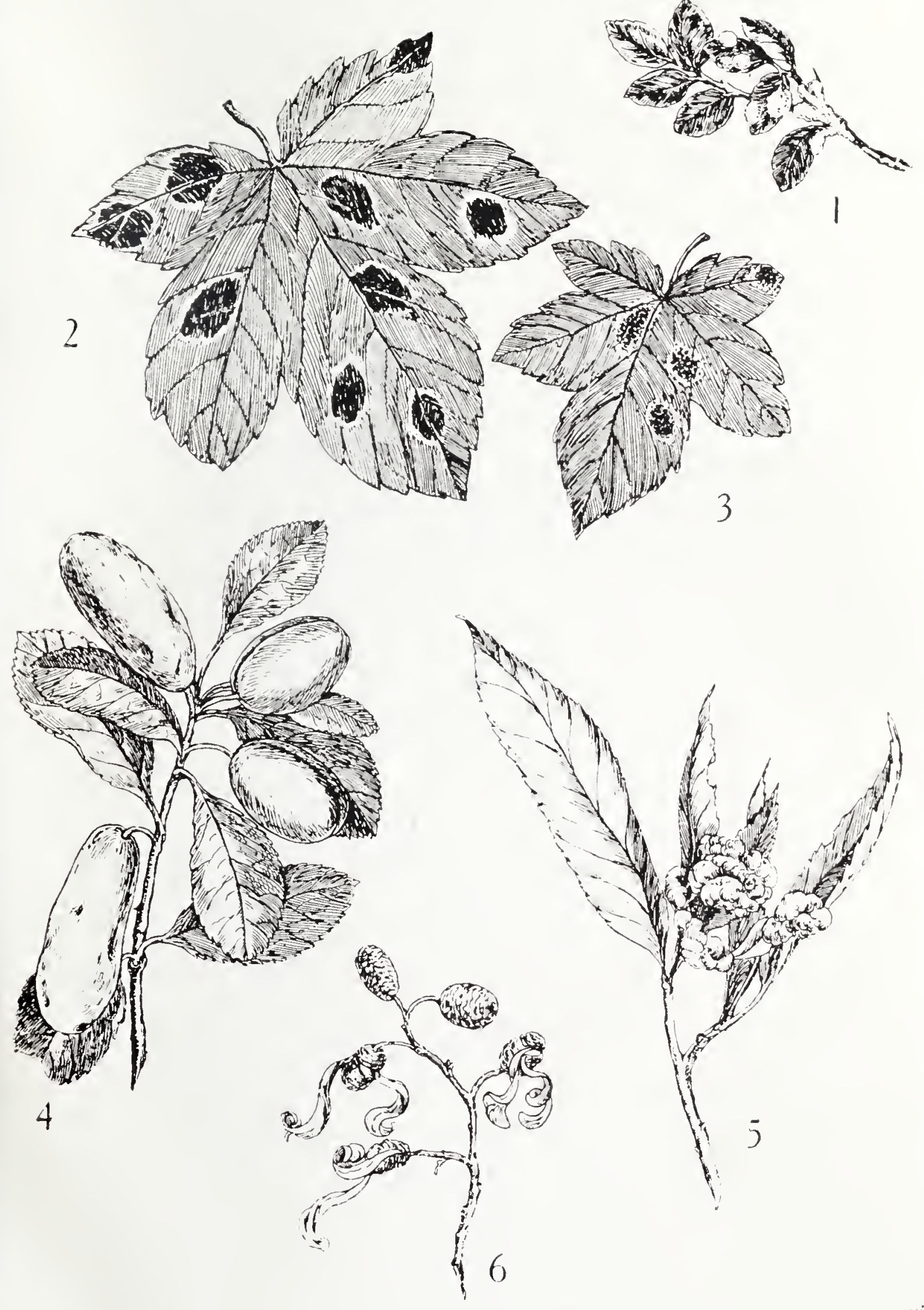




\section{DESCRIPTION OF PLATE XIV}

\section{PARASITES ON LIVING LEAVES, ETC.}

FIG. 1.-Exobasidium vaccinii.

FIG. 2.-Rhytisma acerinum.

FIG. 3.-Rhytisma punctatum.

FIG. 4.-A scomyces pruni.

FIG. 5.-Ascomyces deformans.

FIG. 6.-Ascomyces alnitorquus. 
abundant in the South of England. Diseased leaves often fall before midsummer, and should be carefully collected and burned. Pruning, as in the preceding species, checks the spread of the disease.

Fig. 6. Ascomyces alnitorquns produces blisters on the upper surface of the leaves of the common alder (Almus ghtinosa), and causes remarkable gall-like productions on the female inflorescence. Ascomyces turgidus gives rise to the "witches' besoms" so commonly seen on birch, and particularly noticeable in winter. The asci are formed on the under surface of the leaves, which become discoloured, and appear as if dusted with a greyish hoariness.

Amongst other parasitic Ascomycetes may be mentioned the members of the genus Sclerotinia. Many of these are well-known garden pests. S. sclerotionm (Plate V.) attacks the potato, chrysanthemum, cucumber, etc. It first appears above ground as a delicate white mould, encircling the stem of the attacked plant. The mycelium spreads up into the centre of the stem, in which the black sclerotia may be easily detected in their season. S. tuberosa attacks anemones, wild and cultivated. The sclerotium is attached to the anemone root. The long stem of the ascophore is buried in the ground, hence the fungus appears like a sessile Peziza. Other species of Sclerotinia attack peonies, tulips, and snowdrops. Peziza vesiculosa (Plate XLVII.) is said to attack species of Balsaminia, Hyacinthus, etc., in gardens. The ascophores should be carefully collected and burnt. 


\section{CHAPTER V \\ ECONOMIC AND EDIBLE SPECIES}

$T^{T}$ is estimated that there are about 30,000 valid species 1 of fungi. Of this enormous assemblage, probably not more than 250 are of any economic importance, including about Ioo esculent species.

Some poisonous species are occasionally put to a useful purpose-e.g., an extract of the Fly Agaric (Amanita muscaria) is used in Lapland to poison insects.

Polyporus squamosus and $P$. betulimus were at one time used in the manufacture of razor-strops.

Fomes igniarius, F. fomentarius, and Polyporus sulphuveus were used as tinder in the days of flint and steel. It was prepared by boiling in a solution of nitre. These species were also in request as styptics for slight wounds, and they are still used by the Kamchatkans as snuff. An interesting series of objects (bedroom slippers, smoking-caps, etc.) made from pliant sheets of Fomes fomentarins may be seen in one of the museums at Kew.

Puff-balls were at one time extensively used in rural districts as styptics. The practice has not quite died out, I was recently told by an old Sussex labourer that he always kept a few ripe "puffs" in his/cottage for this purpose. They were also used to stupefy bees, and for tinder. We are reminded of these ancient uses in a poem alluding to some bygone customs, which has the following verse:

"The aged puff balls shall help us to cheat

The dainty bees of their luscious meat;

While others shall turn to give us light,

And scare from our dell the dreary night." 


\section{DESCRIPTION OF PLATE XV}

\section{SOME EDIBLE SPECIES}

I, Lepiota procera; 2 , ditto, section showing the free gills and the bollow stem distinct from the flesh of the pileus; 3, Canthavellus cibarius; 4, ditto, young; 5 , section showing the decurrent gills: 6, Lactarius deliciosus; 7 , ditto, section showing the saffron-red flesh and milk ; 8, Boletus edulis; 9. Fistulina hepatica ; Io, ditto, section showing the red marbled flesh; i , Coprinus comatus, mature plant: I 2, ditto. young; I3, ditto, section of a young plant, showing the reddish purple gills, which become black and drip away at maturity. 


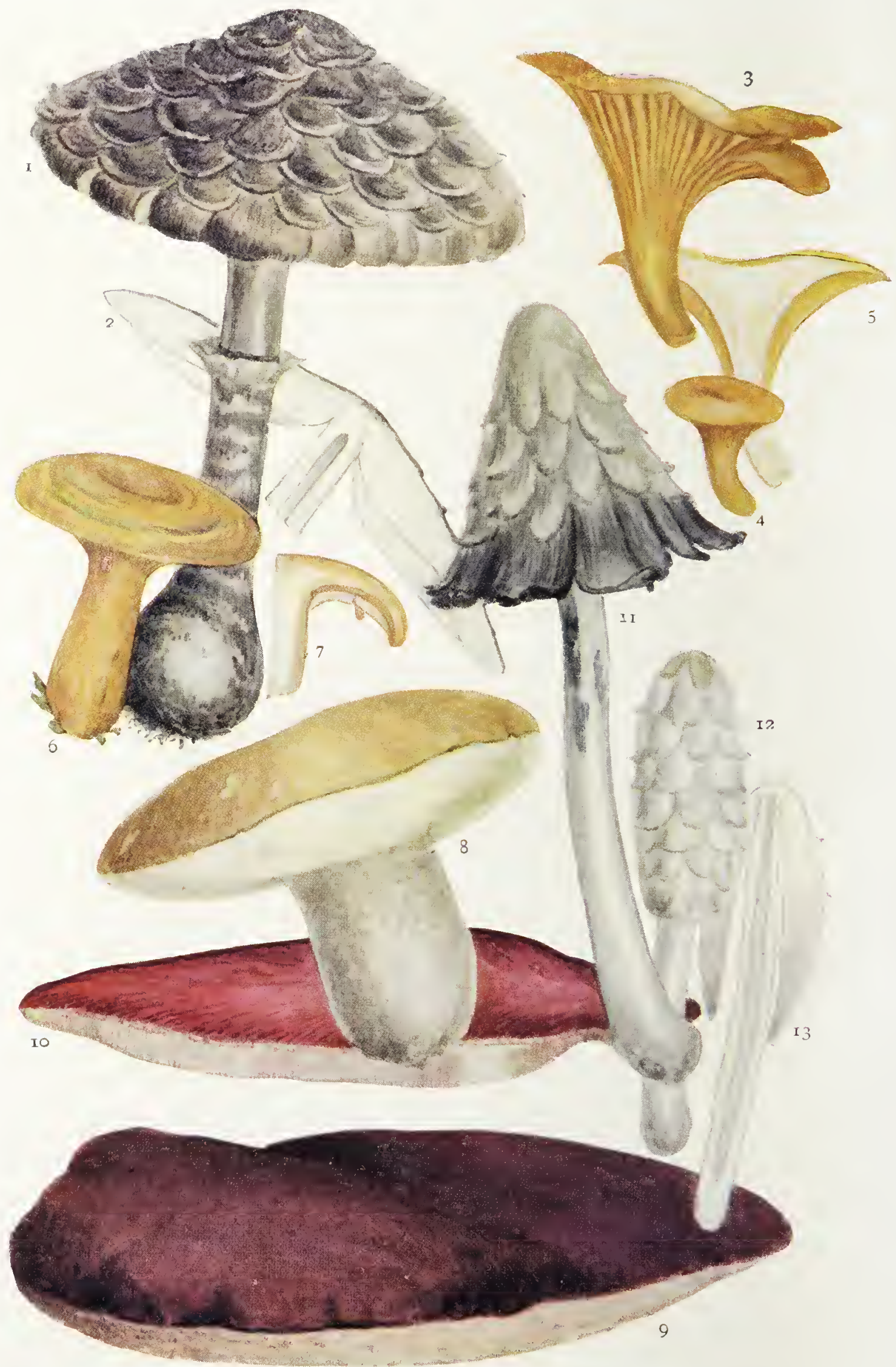


Berkeley remarked (1860) that the "Jew's-ear and the false truffle are still sold in Covent Garden Market in consequence of some supposed healing properties; but they belong to the times of the ancient herbalists, when the doctrine of signatures was prevalent, and are rejected as useless by all respectable practitioners." The Jew's-ear was formerly used as a remedy for dropsy. It is an esteemed esculent in some countries.

Much literature in praise of edible fungi has been, and is being, published; but that fungi can never take the place of meat, nor even claim high rank in our bill of fare, is evident from the experiments of Mr. L. B. Mendel in the Physiological Chemistry Laboratory, Yale University. $\mathrm{He}$ has shown that the proportion of proteid matter (the material supplied by meat) is smaller than is usually supposed; moreover-and this is an extremely important point -a large propoition of it resists the action of the digestive juices. We must also remember that the proportion of water is anything between 70 and 90 per cent.; therefore a fungus contains about as much nutritive material as a turnip (the least nutritious of all our vegetables), and is much more indigestible.

Six species that have been specially recommended for their esculent qualities are depicted on Plate XV. Full details concerning the cooking of these and many other species will be found in Dr. M. C. Cooke's "British Edible Fungi," the standard work on the subject (see Bibliography, p. 45).

Before leaving this subject I feel it necessary to warn would-be experimentalists that a deadly meal may be stewing in the pot unless every possible care has been taken in discrimination. Dr. M. C. Cooke observes that there is no general rule by which good fungi can be distinguished from poisonous ones. "The only safeguard is to become acquainted, by means of well-defined features, with some of $3-2$ 


\section{${ }_{36}$ ECONOMIC AND EDIBLE SPECIES}

the best esculent species, and by no means to experiment with those which are unknown." Dr. Plowright concluded an article on "How to Discriminate between Edible and Poisonous Fungi" (Science Gossip, I896) with the remark: "There is one way, and only one, by which edible fungi can be discriminated from poisonous ones with absolute certainty, and that is by a knowledge of the individual species."

Some of the commonest fungi of our fields and hedgerows are violently poisonous-e.g., Amanita phalloides, which is popularly known by such significant names as the "deathcup," and the "destroying angel." The poisonous principle in this species is called "phalline," and is one of the most potent of known poisons. Its action is evident even when diluted to I part in I25,000.

Sir Jonathan Hutchinson remarks (Haslemere Museum Gazette, 1907): "It is a question of much interest for the farmer, and one which has as yet received little or no attention, whether the deaths of sheep, cattle, and horses may not sometimes be caused by their having eaten poisonous fungi. Sheep do unquestionably sometimes nibble at the Russulas and Amanita phalloides, and they also sometimes die with all the symptoms of agaric poisoning." 


\section{CHAPTER VI}

ON COLLECTING, EXHIBITING, AND PRESERVING FUNGI

$7 \mathrm{HE}$ equipment for the field need not be expensive. It

1 is necessary to be provided with the following:

(I) A pocket lens.

(2) A notebook and pencil.

(3) A strong and serviceable pocket-knife.

(4) A stout chisel, for detachment of woody specimens. The same will be useful for getting up terrestrial species, it being essential in all cases to secure the complete fungus. Some collectors prefer to carry a kind of trowel with a blade about $5 \times 1 \frac{1}{4}$ inches.

(5) A collecting tin, or vasculum. The mycologist's vasculum should be deeper than those usually supplied to botanists, Messrs. Watkins and Doncaster* will supply any size to order. Mine is $16 \times 8 \times 4 \frac{1}{2}$ inches - a very handy size. A cross-handled basket should be carried when collecting a large series of agarics for exhibition purposes.

(6) Some small tins for fragile and minute species. Tins are preferable to cardboard or chip boxes, which quickly collapse when moist.

(7) A hand-saw with adjustable blade (supplied by any ironmonger), for sawing off branches and woody specimens not easily manipulated with the pocket-knife.

There is a widespread but erroneous idea that fungi are only to be found during the autumn months. The majority of fleshy species are at their best from September to Novem-

* 36 , Strand, W.C. 
ber, but many fleshy agarics flourish throughout a mild winter, and several are remarkable in living through low temperatures, notably Hypholoma sublateritius, Pleurotus ostreatus, and Collybia velutipes. In spring several species of the larger Ascomycetes, many polypores, and a few agarics occur; in summer a few bolets, agarics, and phalloids (also many minute species, "rusts" and "smuts," parasitic on living leaves, cereals, etc., not considered in this book); in autumn the greater majority of agarics, many of which appear within a limited time, and then only under favourable conditions; in winter, representatives of the Thelephoraceæ and Polyporaceæ, with a few agarics. Some typical winter species are depicted on Plate I.

To the reader about to take up the study of fungi, and rather at a loss how to begin, I should advise careful exam. ination of the garden, not omitting the trees, then the nearest hedgerow. Enough material will quickly be found to make a good start; the "bag" will almost certainly contain Steveum hirsutum, Polystictus versicolor, Hypholoma fascicularis, and other species delineated on our plates. There should be no difficulty in ascertaining the generic position of a species if the keys to the families and genera are carefully consulted. It is advisable for the first year to aim at the acquisition of a thorough knowledge of a few typical genera. In my experience as museum curator I have often noticed that many young mycologists are prone to acquire only a shadowy knowledge of many species; they can associate them quite correctly with their scientific names, but are unable to point out the distinguishing features of the genera concerned.

To make rapid progress with the study, the beginner should seek election to some field club or society which holds an annual fungus foray. The premier society in this country is the British Mycological, founded in 1896 by Dr. M. C. Cooke, Dr. C. B. Plowright, Mr. Carleton Rea, 
and other leading mycologists. A week's foray is held every autumn, and transactions are published annually. The honorary secretary is Carleton Rea, Esq., B.C.L., M.A., 34, Foregate Street, Worcester.

\section{EXHIBITING FUNGI}

A few notes on the autumnal exhibition of fungi at the Haslemere Educational Museum may not be without interest to the general reader and may be helpful to the teacher.

The specimens are arranged in a long, roomy, and welllighted shed. By keeping the windows and doors open, and placing pans of charcoal about, the strong smell which always emanates from a large collection of fungi is not very pronounced.

All are placed on plates and saucers. Many of the fleshy kinds, notably Boleti and Amanitæ, are changed daily. With those which grow upon wood-also the Hygrophori and other pasture species-a large piece of the matrix is brought away and kept moist in a dish; so treated, they keep fresh for a considerable time, and young plants develop. "Eggs" of Stinkhorn fungi are embedded in damp sand, and placed on a ledge outside a closed window.

Trestle tables are used; the largest is reserved for whitespored agarics, and smaller ones for each of the other spore groups. On each of these tables large descriptive labels, also cards showing the spore-mass of some typical species, are placed. Other tables are allotted to the Gastromycetes, Ascomycetes, and other groups. This arrangement enables the main principles of classification to be demonstrated easily to students and visitors.

Serviceable printed labels for many common species are obtained by cutting up two copies of the "Guide to the Sowerby Models of Fungi at the British Museum of Natural History." 
A microscope for the examination of spores, etc., coloured illustrations of fungi, and the textbooks in general use are placed on the tables. Many young friends are zealous in keeping the exhibition going, bringing in large consignments on half-holidays. A special fungus foray takes place annually, and is always well attended.

\section{PRESERVATION}

Firm, woody fungi may be easily preserved. For this purpose specimens showing traces of incipient decay or insect attacks must be avoided. They should be dried in an oven, or on open trays suspended above a coke stove, and when thoroughly dry be put away in boxes, care being taken to put a lump of albo-carbon in each box as a preventive against attacks by certain minute insects that are the terror of all herbarium makers. The best boxes for the purpose are shouldered glass-topped ones, obtainable from any dealer in natural history material. Full data should accompany each specimen, or it may carry only a number securely fastened to it, the particulars being posted up in a memoranda book. Albo-carbon can be obtained from an ironmonger. It evaporates quickly, and should be renewed three or four times a year. To be absolutely preserved against insects all specimens must be poisoned. This may be done by dipping them in a bath of corrosive sublimate and alcohol in the proportion of $I$ ounce of the former dissolved in a quart of the latter diluted 25 per cent. Hold them for a few seconds in the bath, using a pair of tweezers - not your fingers-and, after allowing them to drip, place them on paper on the drying-tray. They may be dried in the sun, in an oven, or over a coke stove. Children should not be allowed to poison their specimens.

Soft fleshy fungi cannot be preserved except in alcohol or formalin, a proceeding which, for considerations of space, 
can only be recommended for very rare species. Models might be made, but few are able to make them life-like. Sowerby's painful attempts are still on view in the Botanical Gallery at the British Museum of Natural History. The usual plan is to make coloured sketches of agarics and other fleshy species. I quote Dr. M. C. Cooke's advice on this matter (see "Introduction to the Study of Fungi," pp. 347, 348):

"With the soft and fleshy agarics the only method which we are prepared to recommend is to make a sketch or drawing, with the form, size, and colour as in life. It is not absolutely essential that they should be coloured, although that is best, but the colours should always be stated explicitly upon the drawings. To assist those who are not facile with the pencil, it is recommended that the specimen collected should be divided longitudinally through the cap and down the centre of the stem. When this is done, one half should be laid on a sheet of white paper, with the cut surface downwards and the outline traced carefully upon the paper with a sharp-pointed pencil. On removing the specimen there will be left upon the paper an outline of the form of the agaric, natural size. This may be completed by hand, drawing in the line marking the margin of the pileus, indications of scales (if any exist), the character of the ring (if present), and the scales, lines, or markings of the stem. Another copy of the section made side by side on the same paper would give the outline of the gills, and by a little care and practice it would be found easy to draw the line from the stem to the edge of the cap, indicating the point of junction of the gills with the flesh of the cap. This should be done very carefully and accurately, as it must be depended upon to show whether the gills are quite free from the stem at their inner extremity, or whether they are adnexed, or whether they are decurrent, and to what extent they run down the stem. Then, also, it should be shown whether the stem is solid or hollow. A little 
colouring, even if not artistic, would be more useful than mere description of general appearance. Of no less importance is the addition of notes, giving such particulars as cannot be conveyed by the sketch, and these would embrace a statement of habitat, whether growing on the ground or on wood. Amongst other details, it should be stated whether the pileus was dry, or moist, or glutinous; whether the odour was agreeable, or foetid, or indistinct; whether the taste was mild, or acrid, or pungent; and whether the gills exhibited any tendency to deliquesce. Finally, if the drawing was not coloured, then the colour or the pileus and stem must be indicated as explicitly as possible, and not vaguely as red, brown, or grey, but what particular tone of each colour-whether bright red or dull red, dark red or light red, vermilion or crimson, and so on, with any other colour, so that at any time the sketch might be completed in colour and made to represent the species."

Those who despair (after one or two failures) of ever making a good representation of a fungus may take heart from reading Dr. Plowright's remarks on this head in his presidential address at the Dublin meeting of the British Mycological Society (I 898):

"It is very curious how, after a little practice, one is able to catch the character of a fungus on paper, and so, although many of our sketches-at least mine were, I know-were innocent of perspective, devoid of detail in the matter of shading, badly drawn, and worse coloured, yet they formed the basis from which it was possible to construct very useful figures. . . . The point I wish to emphasize is this: That, however rude a sketch may be, it has a definite value, and I would impress upon all those who attempt a study of the Hymenomycetes that they should make coloured outlines of any species that may be new to them. The trouble is not great, but the value, as these sketches accumulate, considerable. Those of us who have devoted any length of 
time to the study of these fungi will not fail to have been struck by the difficulty of recognising species from descriptions, and even with the aid of figures it is not always easy to be sure of your plant. ... The common species are the most difficult to recognise; they are more prone to vary, and many of them are devoid of marked characters."

A collection of photographs, carefully coloured by hand, is of great value.

To obtain a good spore print of an agaric, take an adult, but not obviously old, specimen, cut off the stem close to the gills, taking care not to injure them. Push a long pin partly into the pileus on one side, leaving the head and about I inch exposed, place the pileus gills downwards on a sheet of paper (black for white-spored species) and cover with a bell-glass or place in a glazed case. The spores will be deposited in a few hours, when the fungus may be easily removed by the aid of the pin without smudging the print.

The following directions for fixing spore sprints are taken from Herpel, "Das Präpariren der Hutpilze" :

Paper which is somewhat absorbent must be used; unglazed blue or black paper (of which the colour must be unaffected by the fixative) for white-spored species. The piece of paper bearing the spore print is to be laid, spores upwards, in a flat plate or platter, on which a thin layer of fixative has first been poured. The fixative is allowed to soak up through from below, and should not overflow the edges of the paper. When it is certain that the spores as well as the paper are thoroughly soaked, the preparation is removed and dried, sometimes, to prevent sticking, being laid on moistened blotting-paper.

The fixative to be used will vary with the species. For instance, the spores of Canthavellus cibarius and some others may be fixed by water alone. The following solution is recommended for Boleti and species with coloured spores: 
One part sandarac, 2 parts mastic, and 2 parts Canada balsam, dissolved in 30 parts of 95 per cent. alcohol. In the use of this it has been found that the time of soaking necessary to fix the spores is for Boleti two minutes; Dermini (=Ochrosporæ) Coprinarii, Gomphidius, Paxillus, Russula, and Lactarius four to five minutes; pink-spored agarics, also darl-brown-spored (as the meadow mushroom), and Cortinarii, six to eight minutes. It is important that the alcohol should be full strength.

A gelatine solution is useful for white-spored species. This is prepared and used warm. Its strength varies with the species.

Lepiota procera, Collybia radicäta, and Clitocybe laccata may be fixed by a solution of I part gelatine to 30 parts of water. For species of Tricholoma this is too strong, and I to 60 or I to 200 must be the formula. The difficulty arises here from the fact that an excess of gelatine makes the spores trans. parent, and even invisible. Their opacity may be secured by previous treatment with a solution of I part mastic in 30 parts of ether.

For certain kinds (Tricholoma personatum, Lepiota granulosa, Amanitopsis vaginata, and others which experiment will discover), ro to 25 per cent. of alcohol must be added to the gelatine solution in order to make the spores adhere.

Experience will doubtless show that other fixatives may be used. Gum-arabic, for instance, suggests itself. This, however, if strong, is apt to cake the spores together. If one method fails, invention and repeated trials must find a successful means. 


\section{BIBLIOGRAPHY*}

Berkeley, M. T. Outlines of British Fungology, I860. With 23 coloured plates and one structural plate. Also a supplementary volume by Worthington G. Smith. Lovel Reeve and Co.

Constantin et Dufour. Nouvelle Flore des Champignons, avec 4,I66 figures. Paul Dupont, Paris.

Cooke and Berkeley. Fungi: their Nature, Influences, Uses, etc. Sixth edition. International Scientific Series. Kegan Paul and Co., London.

Cooke, Dr. M. C. Handbook of British Fungi. 2 vols. Macmillan and Co., London.

Cooke, Dr. M. C. Introduction to the Study of Fungi: their Organography, Classification, and Distribution. For the use of collectors. A. and C. Black, London.

Cooke, Dr. M. C. British Edible Fungi: how to Distinguish and how to Cook them, with coloured figures of upwards of 40 species. Kegan Paul and Co., London.

Cooke, Dr. M.C. Illustrations of British Fungi. 8 vols. I, I98 coloured plates, illustrating $I, 420$ species. Published price $£ 30$; now obtainable at less than half-price.

Cooke, Dr. M. C. Mycographia, seu Icones Fungorum. Figures of Fungi from all parts of the world. Vol. I. Discomycetes. II3 plates, illustrating 406 species. Williams and Norgate, London.

Fries, Elias. Monographia Hymenomycetum Sueciae. 2 vols. Upsala, I863. Latin text.

Fries, Elias. Epicrisis Systematis Mycologici, seu Synopsis Hymeno. mycetum. Upsala, I836. Latin text.

Fries, Elias. Systema Mycologicum, Sistens Fungorum Ordines. Genera et Species. 3 vols. Lund, I82I. Latin text.

* Many of the books in this list may be obtained at second-hand prices. In this connection I may mention that Mr. Thomas Thorp, I8, Chapel Street, Guildford, makes a speciality of second-hand botanical literature. 
Frics, Elias. Icones Selectae Hymenomycetum. Coloured plates. Folio. Stockholm, I867-I882. Latin text.

Fries, Elias. Hymenomycetes Europaei. Upsala, 1874. Latin text. Lloyd, C. G. Mycological Writings. Numerous monographs (profusely illustrated), chiefly concerning the Gasteromycetes and Poly poraceæ. Privately printed.

Mussee, George. British Fungus Flora. A classified textbook of Mycology. 4 vols. I892-I895. George Bell and Sons, London.

Massee, George. Textbook of Plant Diseases caused by Cryptogamic Parasites. I899. Duckworth and Co., London.

Massee, George. European Fungus Flora: Agaricaceæ. I902. Duckworth and Co., London.

Massee, George. Textbook of Fungi, including Morphology, Physiology, Pathology, Classification, etc. rgo6. Duckworth and Co., London.

Mycological Socicty, British. Transactions. Numerous coloured plates of new and rare species. Obtainable only from the Honorary Secretary, 34, Foregate Street, Worcester.

Phillips, William. Manual of British Discomycetes. Second edition. International Scientific Series. Kegan Paul and Co. London.

Quélet, Lucien. Flore Mycologique de la France et des Pays Limitrophes. Paris, I888.

Smith, Worthington G. Synopsis of the British Basidiomycetes. 1908. A Descriptive Catalogue of the Drawings and Specimens in the Department of Botany, British Museum. Ios.

Smith, Worthington G. Guide to Sowerby's Models of British Fungi in the Department of Botany, British Museum (Natural History). Second edition. 1908. Post free, $5 \frac{1}{2} \mathrm{~d}$. This and the preceding are sold at the British Museum, Cromwell Road.

Stevenson, John. British Fungi (Hymenomycetes). 2 vols. 1886. Blackwood and Sons, Edinburgh. 


\section{GLOSSARY}

Aberrant ( $a d$, from; erro, I wander). Differing from the customary structure of related groups.

Aculeate (aculeus, a prickle). Armed with prickles.

Acuminate (acumer, a point). Tapering to a point.

Adherent ( $a d$, to ; haereo, I stick). Grown to or sticking to.

Adnate (adnascor, to grow to). Of gills, broadly attached to the stem.

Adnexed (ad, to; necto, I join). Of gills, just reaching the stem.

Adpressed (ad, to ; pressus, pressed). Close contact, but not joined.

Analogy (Gr. ana, according to ; logos, definition). Resemblances in certain respects only, not in the plan of structure.

Anastomose ( $\mathrm{Gr}$. anastomosis, a bringing to a point). Of veins united in an irregular manner.

Annulus (annulus, a ring). The ring round the stem.

Apex (apex, the top). Opposite to the point of attachment.

Apiculate (apex, the top). Ending in a little point.

Approximate ( $a d$, to; proximo, to approach). Of gills, approaching to, but not actually touching, the stem.

Arcuate (arcuatus, bent like a bow). Applied to gills when bow-shaped. Areolate (area, a plot). Divided into small areas or patches.

Ascus (Gr. askos, a leather bottle). The swollen end of a hyphal branch in which the spores are contained in the Ascomycetes. Plural, Asci.

Basidium (basidium, a little pedestal). The mother cell bearing the spores in the Basidiomycetes. Plural, Basidia.

Biennial (biennis, of two years' continuance). Growing one year, flowering or fruiting the succeeding year. Of two years' duration.

Bullate (bulla, a bubble). Furnished with a stud or boss-like appendage.

Caducous (caducus, ready to fall). Falling off, not persistent.

Caespitose (caepes, a clump). Growing in tufts.

Campanulate (campamula, a little bell). Bell-shaped.

Capillary (capillus, a hair). Thread-like. 
Capillitium (capillitus, like hair). The sterile threads intermixed with the spores in the gleba of the Gasteromycetes.

Capitate (caput, a head). Furnished with a globose head.

Cinereous (cinis, ashes). Ash-coloured.

Clavate (clava, a club). Gradually thickened upwards; club-shaped.

Columella (columella, a small pillar). The sterile base as seen in some Gasteromycetes.

Conidia (Gr. konis, dust). Dust-like secondary spores.

Cordate (cor, the heart). Heart-shaped.

Coriaceous (corium, leather). Of a leathery consistency.

Cuticle (cuticula, the outer skin). The outermost skin or pellicle.

Cyathiform (Gr. kuathos, a wine-cup). Cup-shaped.

Deciduous (decidurs, subject to falling). Falling, or subject to fall, in season.

Decumbent (decumbens, lying down). Lying on the ground with a tendency to rise at the ends.

Decurrent (decurrens, running down). Of gills, when prolonged down the stem.

Dentate (dens, a tooth). Toothed.

Denticulate (dens, a tooth). Minutely toothed.

Determinate (determino, to limit). With a definite margin, as in some species of Corticium; the margin not clouded off indefinitely.

Diaphanous (Gr. dia, through; phaino, to appear). More or less transparent.

Dichotomous (Gr. dichotomeo, to cut in two). Divided into two, forked. Dimidiate (dimidio, to halve). As when the sporophore is smaller in one part, as seen in the pilei of many species.

Dissepiments (dissepimentum, a partition). Dividing walls, as between the pores in the Polyporaceæ.

Distant. A term applied to the gills of agarics having a wide space between them-i.e., not at all crowded.

Echinate (echinatus, set with bristles). Furnished with stiff prickles.

Effused (effundo, to pour over). Spread over the matrix without any definite form.

Emarginate (e, out of; margo, the margin). Having a notch at the end. Applied to the gills of agarics when they are notched or scooped out before reaching the stem.

Endoperidium (Gr. endon, within; peridion, a little pouch). The inner layer of the peridium in the Gasteromycetes.

Epiphyte (Gr. epi, upon; pluton, a plant). Growing upon another plant, but not nourished by it.

Erumpent (erumpens, breaking through). Bursting through the bark. Evanescent (evanescens, disappearing). Lasting only a short time. 
Excentric (ex, out of ; centrum, the centre). Out of the centre, onesided.

Exoperidium (Gr. exo, without; peridion, a little pouch). The outer layer of the peridium in the Gasteromycetes.

Farinose (farina, flour). Covered with a white mealy powder.

Fasciculate (fascis, a bundle). Growing in small bundles.

Fastigiate (fastigiatus, sharpened upwards). Nearly parallel, pointing upwards, and decreasing in height outwards.

Ferruginous or Ferrugineous (fermm, iron). The colour of iron-rust.

Fibrillose (fibra, a fibre or filament). Covered with loose small fibres.

Filiform (filum, a thread). Slender as a thread.

Fimbriate (fimbria, a fringe). Fringed.

Fistular or Fistulose (fistulosus, hollow). Hollow through the whole length, like a pipe.

Flexuose (flexuosus, full of turnings). Zigzag, wavy.

Foliaceous (folium, a leaf). Leaf-like in appearance.

Free. A term applied to gills which reach the stem, but are not joined to it.

Fugacious (fugax, fading). Falling or fading quickly, lasting a very short time.

Funiculus (funis, a rope). The cord attaching the "egg" to the " nest" in some of the "Bird's-nest" fungi.

Furcate (furca, a fork). Forked, as in the brancling gills commonly seen in the genus Russula.

Furfuraceous (furfur, bran). Scurfy, covered with bran-like scales.

Fusiform (fusus, a spindle). Spindle-shaped, tapering gradually to each end.

Gibbous (gibbus, hump-backed). A pileus with a broad umbo.

Gills. The vertical plates of an agaric bearing the hymenium.

Glabrous (glaber, smooth). Smooth, not hairy.

Glaucous (glaucus, sea-green). Covered with a bloom of a bluish-green tinge.

Gleba (gleba, a clod). The inner substance of the peridium in the Gasteromycetes.

Globose (globo, globatus, to form into a ball). Nearly round.

Grumous (grumus, a hillock). Flesh composed of little grains.

Gyrose (gyrus, a circle). Marked with wavy lines, curved backward and forward in turn.

Habit (habitus, appearance). The general appearance of a plant.

Habitat (habitatio, a habitation). The situation of a plant in its wild state. 
Heterogeneous (Gr. heteros, one of two; gennao, to beget). Not uniform in structure.

Hirsute (hirsutus, hairy). Provided with hairs.

Hispid (hispidus, rough). Covered with long, stiff hairs.

Homogeneous ( $\mathrm{Gr}$. homos, one and the same; gennao, to beget). All of one nature or kind, uniform in structure.

Hyaline (Gr. hualos, clear). Transparent, colourless.

Hygrometric (Gr. hugros, moist; metron, a measure). Influenced by moisture.

Hygrophanous (Gr. hugros, moist; phaino, to appear). Of a watery appearance when moist.

Hymenium (Gr. humen, a membrane). The part on which the spores are borne.

Hymenophore (Gr. humen, a membrane; phero, to bear). The structure carrying the bymenium-e.g., the pileus to which the gills are attached in the Agaricaceæ.

Hypha (Gr. huphe, a web). The thread-like element of which a fungus is made up. Plural, Hyphe.

Imbricate (imbricatus, covered with tiles). Overlapped, like the tiles of a house.

Immarginate (in, without; margo, a border). Having no distinct rim or border.

Indehiscent (in, without; dehisco, I gape). Not splitting when ripe; not opening in a definite manner.

Indigenous (indigenus, native). Native and original to the country.

Inferior (inferior, lower). Of the ring on the stem when far down; of the hymenium when protected by a pileus.

Infundibuliform (infundibulum, a funnel). Funnel-shaped.

Involute (involutus, wrapped up). With the edges rolled inwards.

Laciniate (lacinia, a fringe). Fringed; divided into flaps.

Lacunose (lacuna, a little hole). Pitted, or having little cavities.

Lamellæ (lamella, a thin plate). The thin plates or gills of the Agaricaceæ.

Lanceolate (lancea, a lance or spear). Narrowed and tapering to both ends.

Latex (latex, juice). The fluid or "milk" present in the cells of certain fungi.

Lacticiferous (latex, juice; fero, I bear). Of cells containing or conveying juice.

Lenticular (lens, a lentil). Resembling a double convex lens.

Lurid or Livid (lividus, black and blue). Discoloured. 
Mammiform (mamma, a breast). Breast-shaped.

Marginate (margo, an edge or margin). Having a clearly-defined margin or border.

Matrix (matrix, the womb). The substance upon which a fungus grows.

Mesopod (Gr. mesos, middle; pous, a foot). Having a central stem.

Multifid (multus, many; fidus, cleft). Cut into many segments or lobes. Mycelium (Gr. mukes, a mould). The vegetative portion or spawn of fungi, composed of hyphæ.

Mycology (Gr. mukes, a fungus; logos, a discourse). The study of fungi.

Nodulose or Nodular (nodulus, a little knot). Knotted.

Nuclear (nucleus, a kernel). With a kernel-like central growth, as in the genus Næmatelia.

Oblong (oblongus, oblong). Considerably longer than broad, and with nearly parallel sides.

Obovate (ob, inversely; ovatus, egg-shaped). Ovate, with the broader end towards the apex.

Obtuse (obtusus, blunt). Blunt or rounded at the end.

Ochreous (ochra, yellow earth). Yellow, not red, ochre.

Opaque. Mostly used in the sense of dull, not shining.

Operculum (operculum, a lid). A cover.

Orbicular (orbiculus, a little ball). Circular; a flat body with a circular outline.

Ovate (ovum, an egg). Egg-shaped.

Papilla (papilla, a nipple). A nipple-like projection; hence papillate. Paraphyses (Gr. para, beside; phusis, growth). Sterile threads in the hymenium of some fungi.

Pectinate (pecten, a comb). With narrow, close segments, like the teeth of a comb.

Pedicel (pediculus, a small foot). A secondary stalk or support; hence pedicellate.

Perennial (perennis, durable). Lasting some years.

Peridium (Gr. peridion, a little pouch). The outer cover investing the gleba in Gasteromycetes.

Peronate (pero, a kind of high boot). Sheathed-a term applied to a stem with a woolly covering.

Pileate (pileus, a cap). Having a cap or pileus.

Pileus (pilens, a cap). A term usually applied to the cap-like head of a fungus protecting the spore-bearing surface beneath.

Pilose (pilus, hair). Hairy. 
Pinnatifid. See Pectinate.

Pisiform (pisum, a pea). Pea-shaped.

Plicate (plica, a fan). Folded or plaited lengthwise like a fan.

Pores (Gr. poros, an opening). Openings or orifices for the escape of the spores; hence porous.

Procumbent (procumbens, bending downwards). Lying flat on the ground.

Proliferous (proles, a race; fero, to bear). The secondary development of parts on the same organ.

Pruinose (pruina, hoar-frost). As if frosted over with a powder or bloom.

Pubescent (pubescens, downy). Downy ; slightly hairy.

Pulverulent (pulvenulentus, dusty). Powdered as if with dust.

Pulvinate (pulvinus, a cushion). Cushion-shaped.

Pyriform ( $p y r u s$, a pear). Pear-shaped.

Remote. A term applied to the gills of Agaricaceæ when they do not reach the stem, but leave a space round it.

Reniform (renes, the kidneys ; forma, shape). Kidney-shaped.

Repand (repandus, to throw open). Bent backwards.

Resupinate (resupinatus, lying on the back). With the hymenial surface upwards; without a free margin.

Revolute (vevolutus, rolled back). Rolled backwards; the opposite of involute.

Rimose (vima, a cleft or crack). Marked by chinks or cracks, as in old bark.

Rufescent (rufus, red, reddish). Becoming reddish; hence rufous.

Rugose (nuga, a wrinkle). Covered with wrinkled lines.

Rugulose. Somewhat wrinkled, not markedly so.

Scabrous (scaber, rough). Rough to the touch.

Sclerotium (Gr, sklcros, hard). A compact, hard mass of hyphæ in a dormant condition.

Scrobiculate (scrobiculus, a little ditch). Marked with little pits or depressions.

Septate (septum, a hedge). Having divisions or partitions.

Serrate (serra, a saw). Toothed in a saw-like manner.

Serratulate. Minutely toothed.

Sessile (sessilis, sitting). Sitting close ; without a stem.

Sinuate (simuatus, crooked). With a wavy margin when applied to the pileus; of gills when they have a sudden curve where they reach the stem.

Spores (Gr. spora, a seed). The reproductive bodies of cryptogams, analogous to the seeds of flowering plants. 
Sporophore (Gr. spora, a seed; phoveo, to carry). The part which bears the hymenial surface.

Squamulose (squama, a scale). Scaly; covered with small scales.

Squarrose (squarrosus, rough). Rough with projecting or reflexed scales.

Stellate (stella, a star). Like a star ; radiated.

Sterigma (Gr. sterigma, a prop). The points or threads to which a spore is attached. Plural, Sterigmata.

Sterile (stevilis, barren). Incapable of producing spores or seeds.

Stipitate (stipes, a stem). Having a stalk or stem.

Striated (striatus, channelled). Streaked with longitudinal lines.

Strigose (striga, a ridge). Covered with sharp-pointed rigid hairs.

Stuffed. Of a stem filled with a substance differing in texture from its walls.

Subiculum (subiculum, an under layer). The felted layer of mycelium beneath certain resupinate fungi.

Sulcate (sulcus, a furrow). Marked with grooves.

Superior (super, above). Applied to a ring when it is near the apex of the stem; to the hymenium when it is uppermost, not protected by a pileus.

Synonym. A superseded or unused name.

Tessellate (tessellatus, squared stones). Marked or mapped out in little squares.

Tomentose (tomentum, flocks of wool). Downy with minute short hairs. Trama (trama, the weft or filling of a web). The substance between the hymenial layers in the Agaricacex and Polyporaceæ.

Tremelloid (tremo, I tremble). Jelly-like in substance.

Triennial (tricmis, of three years' continuance). Lasting for three years; of mycelium, producing sporophores in the third year.

Truncate (truncus, a stump). Terminating very abruptly, as if cut.

Tuberculate (tuberculum, a little tuber). Covered with small warty projections.

Tubular (tubus, a tube). Hollow and cylindrical like a pipe.

Turbinate (turbo, a top). Top-shaped.

Umbilicate (umbiticus, the navel). Having a small central depression.

Umbo (umbo, a boss). A central elevation like the boss of an ancient shield; hence Umbonate.

Universal. A term applied to the volva or veil which completely envelopes some fungi when young.

Veil (velum, covering), The membrane which more or less completely covers some fungi at first. 
Ventricose (venter, the abdomen). Swelling unequally on one side, or swollen in the middle.

Vermiform (vermis, a worm). Worm-shaped.

Verrucose (vervuca, a wart). Covered with warts.

Villose (villus, a tuft of woolly hair). Covered with long weak hairs or down.

Virgate (virga, a twig or stripe). Streaked.

Viscid (viscidus, sticky). Covered with a tenacious gluten or secretion.

Volva (volva, a wrapper). A covering which envelopes certain fungi at first; hence Volvate.

Zones. Circles of hairs, warts, colour, etc., frequently seen on the pileus in the Hymenomycetes; hence Zoned. The term is usually applied to bands of colour. 



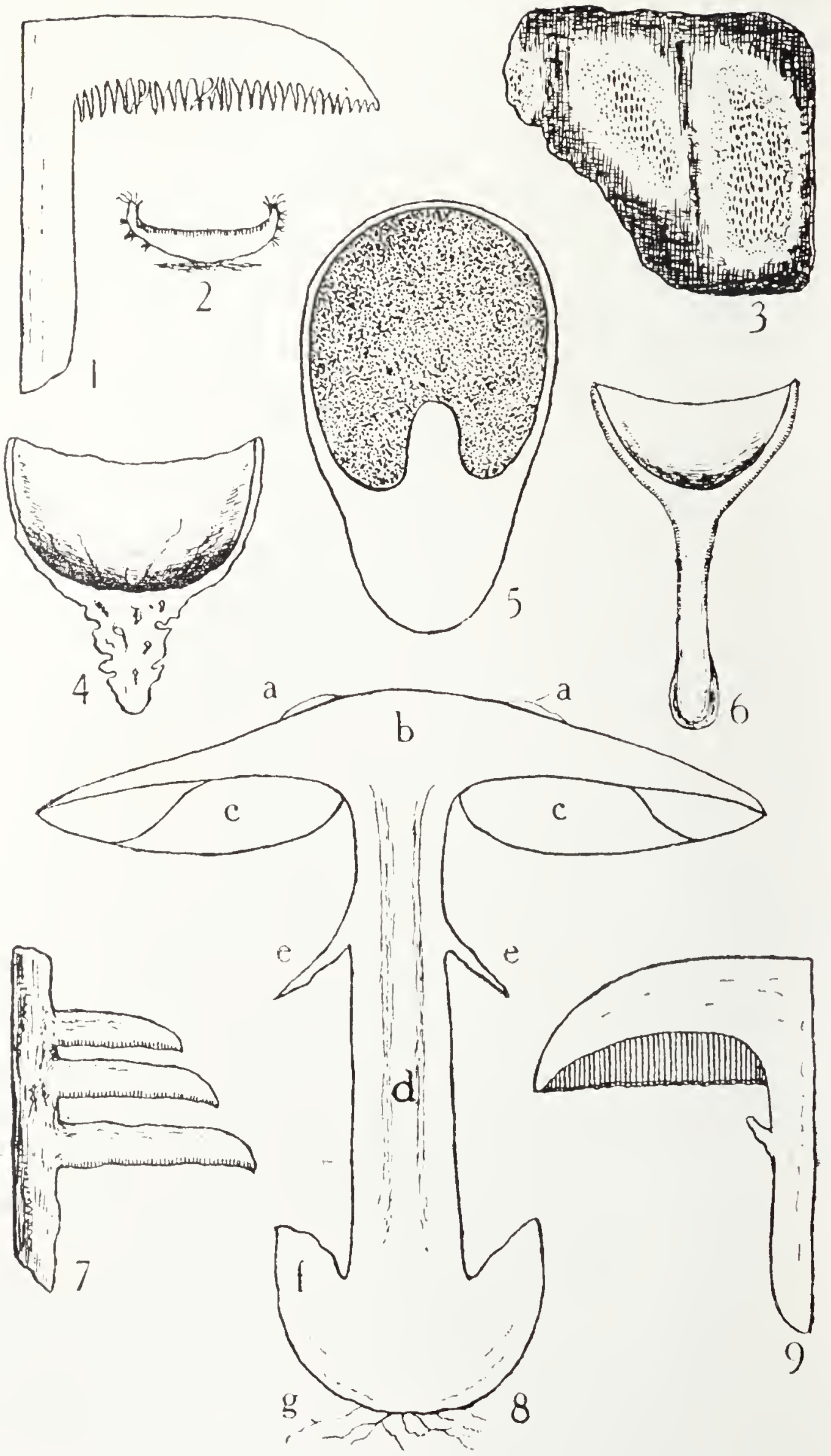




\section{PART II \\ CLASSIFICATION AND DESCRIPTION OF SPECIES}

In the following pages all the genera of British Basidiomycetes are described, also one or more typical species in each genus.

The analytical keys to the genera of Hymenomycetes are based upon Carleton Rea's lucid paper, "Outline of the Classification of the Hymenomycetes," published in IgO4 in the Transactions of the Worcestershire Naturalists' Club.

A few of the larger Ascomycetes are also described and illustrated. The times of appearance are given under the seasons, and are normal. A species may, under certain conditions, be found in winter, though stated to occur in autumn.

The measurements of the sporophore, peridium, pileus, and ascophore are always those of diameter, unless otherwise stated, and those of the stem its height. The dimensions given are those of typical welldeveloped specimens.

Limitations of space compelled the frequent use of technical terms in describing the species, but the glossary and the notes on the plates should make these easily intelligible.

The following abbreviations are employed :
$P$. pileus.
Per. peridium.
S. stem.
Sph. sporophore.
G. gills.
Asc. ascophore.
$F$. flesh.
Pov. pores.
$R$. ring.
spr. spring.
$V$. volva.
sume. summer.
$T$. tubes.
aut. autumn.
$H$. hymenium.
win. winter.

diam. diameter.

in. inch or inches. 


\begin{tabular}{|c|c|c|c|c|c|c|c|c|c|}
\hline 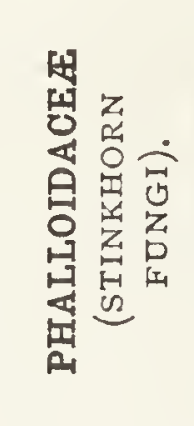 & 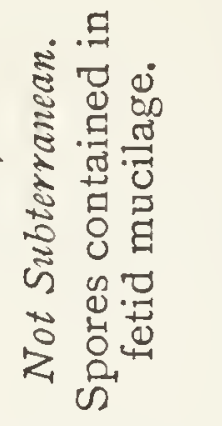 & 吕 & 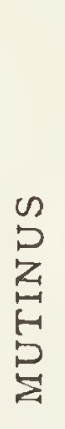 & 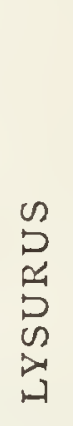 & 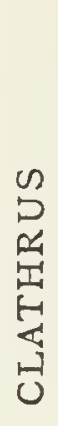 & & & & \\
\hline 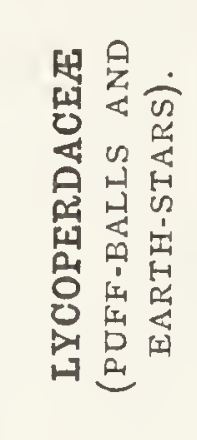 & 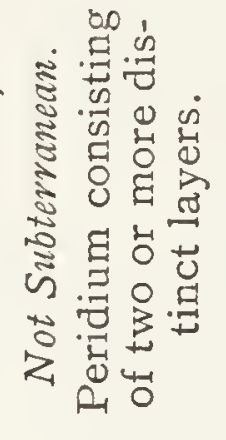 & 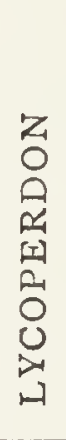 & 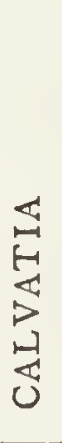 & 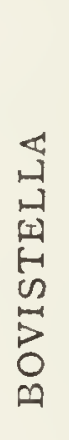 & 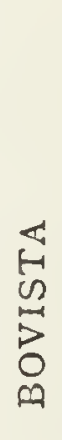 & 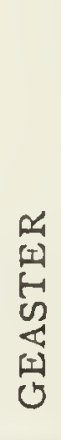 & $\begin{array}{l}\vdots \\
\vdots \\
0 \\
H \\
0 \\
0 \\
.1 \\
0 \\
0 \\
H\end{array}$ & 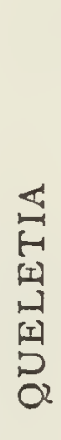 & 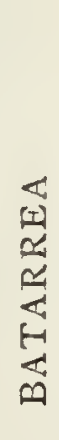 \\
\hline 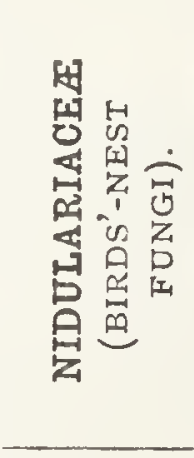 & 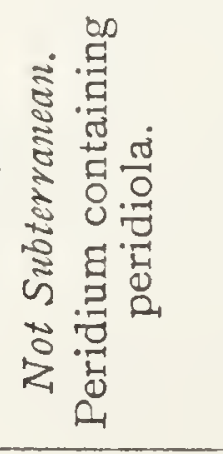 & 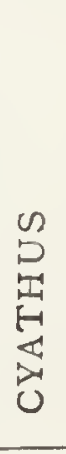 & 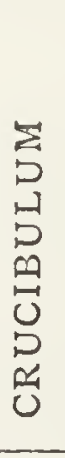 & 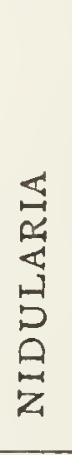 & 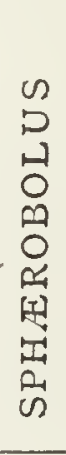 & & & & \\
\hline 出 & 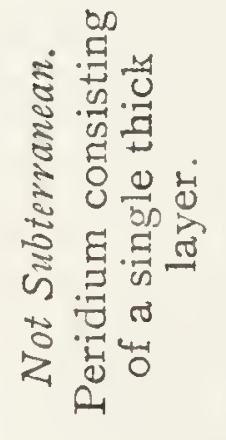 & 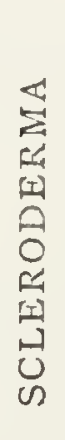 & 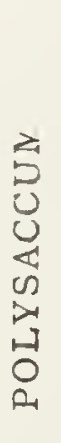 & & & & & & \\
\hline 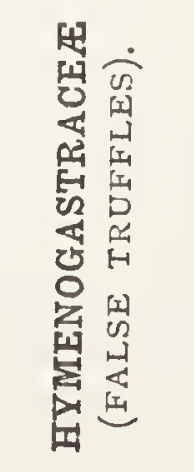 & 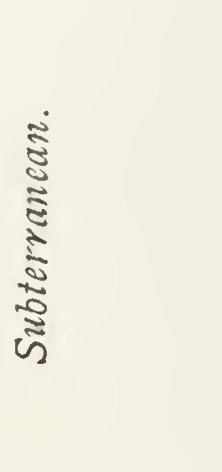 & 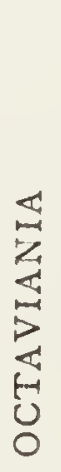 & 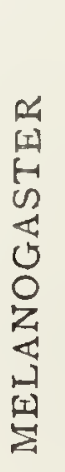 & 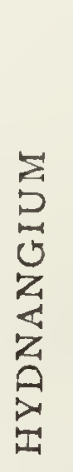 & 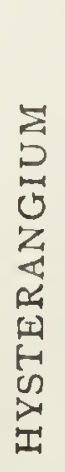 & 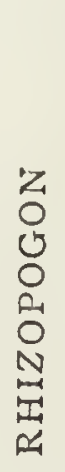 & 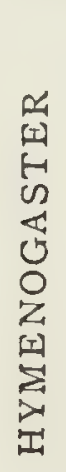 & & \\
\hline
\end{tabular}




\section{PART II}

\section{Order BASIDIOMYCETES}

Spores borne on basidia in definite numbers, usually four.

\section{Sub-order GASTEROMYCETES}

Hymenium contained within a continuous membrane or peridium until the spores are mature.

\section{KEY TO THE FAMILIES}

\section{A. Subterranean}

I. HYIMENOGASTRACE王 (the False Truffes).-Fleshy, more or less spherical or nodular fungi ; the interior (gleba) not breaking up and becoming powdery; outer envelope decaying at maturity, not rupturing to liberate the spores.

\section{B. Above Ground from the First or at Maturity}

II. SCLERODERMACE开 (the Earth-balls).-.-Spherical, with a thick skin or peridium ; rupturing irregularly ; the interior not breaking up and becoming powdery. Capillitium threads absent or scanty.

III. NIDULARIACE正 (the Birds'-nest Fungi).-Small, more or less cup-shaped at maturity, containing several (rarely one) lenticular or subglobose bodies (sporangiola) enclosing the spores.

IV. LYCOPERDACE (the Puff-balls and Earth-stars).-Peridium thin, usually consisting of two layers. Gleba cavernous at first, resolving itself into a powdery mass of spores and capillitium threads at maturity.

V. PHALLOIDACE $\mathbb{E}$ (the Stinkhorns),-Peridium with a central gelatinous layer. Spores immersed in a highly fetid gluten. 


\section{Family HYMENOGASTRACEZE}

(The False Truffles)

KEY TO THE GENERA

Octaviania. Sterile base present. Spores globose, warted.

Melanogaster. Sterile base absent. Gleba cells larger in the centre.

Spores elliptical, smooth. Peridium traversed by branching fibres.

Hydnangium. Sterile base absent. Spores globose, warted.

Hysterangium. Peridium separable. Mature gleba of a cartilaginous mucus consistency.

Rhizopogon. Gleba cells of equal size. Peridium traversed by branching fibres.

Hymenogaster. Sterile base present. Spores elliptical, rugulose.

\section{OCTAVIANIA}

\section{(After Dr. Vincent Ottaviani)}

O. asterosperma (Gr. astev, a star; sperma, a seed-from the star-shaped spores). Plate XVII. 9.

Per. I $\frac{1}{2}$ in., globose, whitish, becoming greenish-blue or black when bruised, always with abundant cord-lile mycelium. Amongst rotten branches and leaves in aut., near the surface or partially exposed. Smell sweet. Frequently attacked by a bright orange mould, Sepedonium cluvysospermum.

\section{MELANOGASTER}

(Gr. melas, black; gaster, the stomach-from the black interior)

M. variegatus (from the variegated gleba).

Pev. $2 \frac{1}{2}$ in., globose or nodularly oval, yellowish, minutely granular; section blue-black, marbled with yellow; cells larger in the centre. Scentless at first, with a pleasant almondy smell at maturity. This is the "Red Truffle" of Bath, sold in the markets of that city in the early part of 

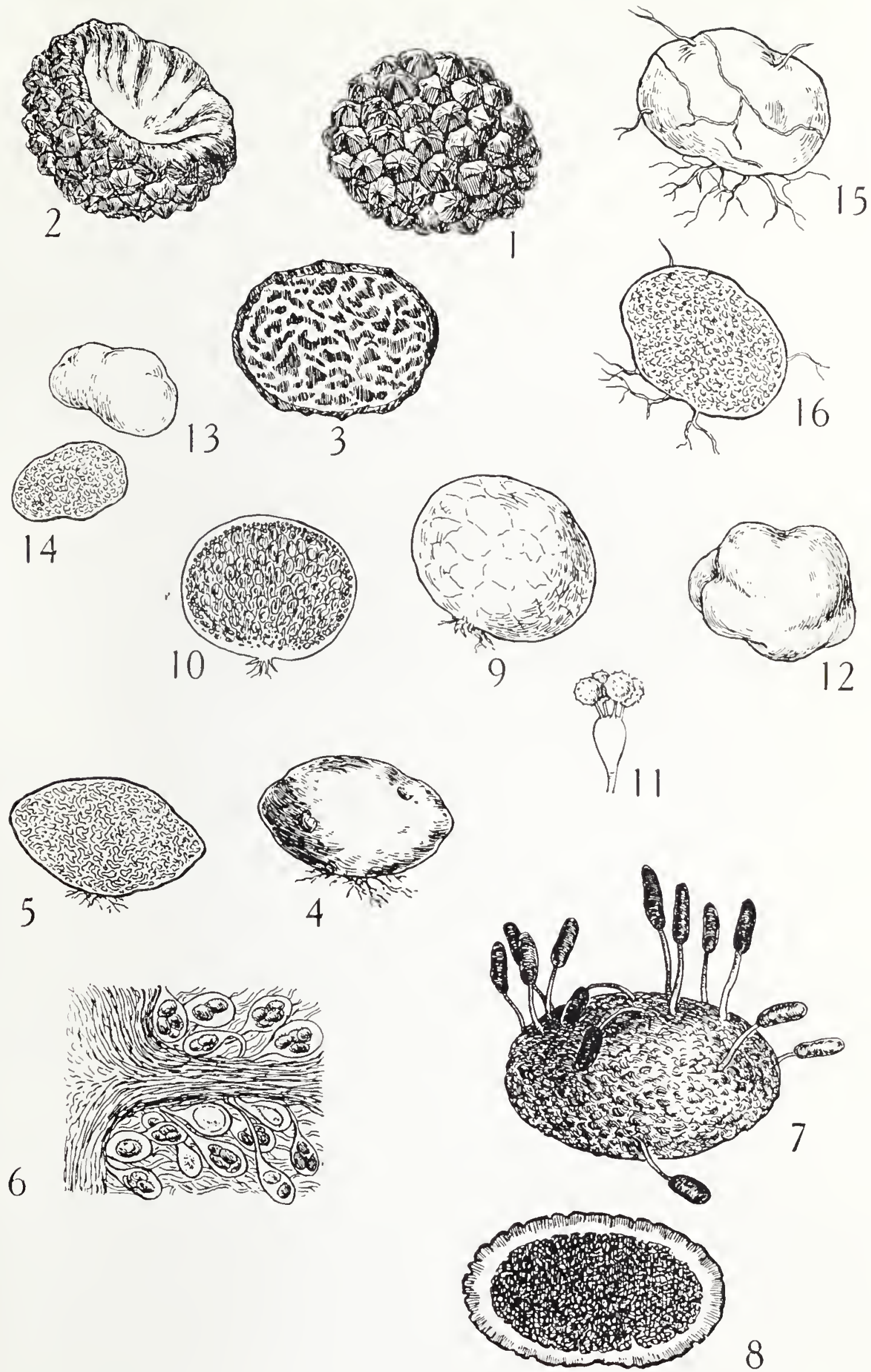


\section{DESCRIPTION OF PLATE XVII}

\section{TRUFFLES AND FALSE TRUFFLES}

Figs. I to 8 are Truffles (Ascomycetes); Figs. 9 to I6 are False Truffles (Gasteromycetes).

FIG. I.-Tuber estivum.

FIG. 2.-Ditto, gnawed by a squirrel.

FIG. 3.-Section of Tuber astivum.

FIG. 4.-Choiromyces meandriformis.

FIG. 5.-Ditto, section.

FIG. 6. - Tuber rufum: asci containing spores; highly magnified.

FIG. 7.-Elaphomyces variegatus, with Cordyceps ophioglossoides growing upon it.

FIG. 8.-Section of Elaphomyces variegatus.

FIG. 9.-Octaviania asterosperma.

FIG. Io.-Ditto: section showing the large and irregular central cells and the smaller and spherical outer ones.

FIG. Ix.-Basidium and spores of Octaviania asterosperma; highly magnified.

FIG. I2.-Hymenogaster citrimus.

FIG. 13. - Hydnanginm carotecolor.

FIG. I4.-Ditto, section.

FIG. I5.-Rhizopogon vubescens, showing the vein-like fibres on the peridium.

FIG. x6.-Ditto, section. 
the last century, but not obtainable there now. It occurs in twos and threes-usually partly exposed-chiefly under beeches and Lombardy poplars, in sum. and aut.

\section{HYDNANGIUM}

(Gr. hudnon, a truffle or tuber; aggeion, a vessel-from the tuberous form)

H. carotæcolor (carota, carrot-from the colour). Plate XVII. I3.

Pev. I $\frac{1}{8}$ in., irregularly oblong, reddish; carrot-colour within. In woods and under trees on downs in aut. and win. Often exposed.

\section{HYSTERANGıUM}

(G. hustera, the womb; aggeion, a vessel-from the shape)

H. nephriticum (Gr. nephros, the kidneys-from the supposed resemblance of a section to a kidney).

$P e r . \frac{3}{4}$ in., irregularly globose, indented, firm, tomentose, white becoming reddish when bruised. Section pale blue or grey, here and there greenish, the cells radiating from the base. In woods, chiefly on clay soil, aut. and win. Usually buried 8 or 9 in. Smell strong at maturity, like rotting puff-balls.

\section{RHIZOPOGON}

(Gr. vhiza, a root; pogon, a beard-from the tuberous growth and attached fibres)

R. rubescens (rubescens, becoming red-from, the reddish tint when bruised). Plate XVII. 5 .

Per. I $\frac{3}{4}$ in., irregularly subglobose, white at first, then yellow or olive-brown, becoming reddish when bruised. Frequent in aut. and early win. in sandy fir woods. Gregarious, either exposed or buried several inches. 


\section{HYMENOGASTER}

(Gr. humen, a membrane; gaster, the stomach-from the usually thin peridium)

H. citrinus (citveus, lemon-yellow-from the colour). Plate XVII. I2.

Pev. I $\frac{1}{4}$ in., irregularly globose, lobed or deformed, shining like silk, yellowish at first, reddish-black at maturity. Easily recognised by the yellow tramal walls and the very pronounced smell of cheese. May to Dec. in woods. Formerly eaten in the West of England.

\section{Family SCLERODERMACE\&}

(The Earth-balls)

\section{KEY TO THE GENERA}

Scleroderma. Peridium with warted or granular surface. Gleba cellular. Cells without peridiola.

Polysaccum. Peridium with a smooth surface. Gleba composed of distinct cells containing peridiola.

\section{SCLERODERMA}

(Gr. skelvos, hard ; devma, skin-from the hard peridium)

S. aurantium (aurantiacum, orange-yellow - from its colour). "Common Earth-ball." Plate XVIII. I.

This is the common form of Sclevoderma vulgave of our textbooks, which some authorities split up into two formsaurantium, with large, rough, scaly warts; cepa, relatively smoother and paler.

Per. I-3 in., white or yellowish-brown, often pinkish when cut; subsessile. Spore mass blackish, with an olive tinge. Gregarious or cæspitose; very common on light sandy soils in hedges and under trees. An atrophied form (S.cervinum), found occasionally in dry fir woods, is less than I in. across and densely granular, superficially resembling Elaphomyces 

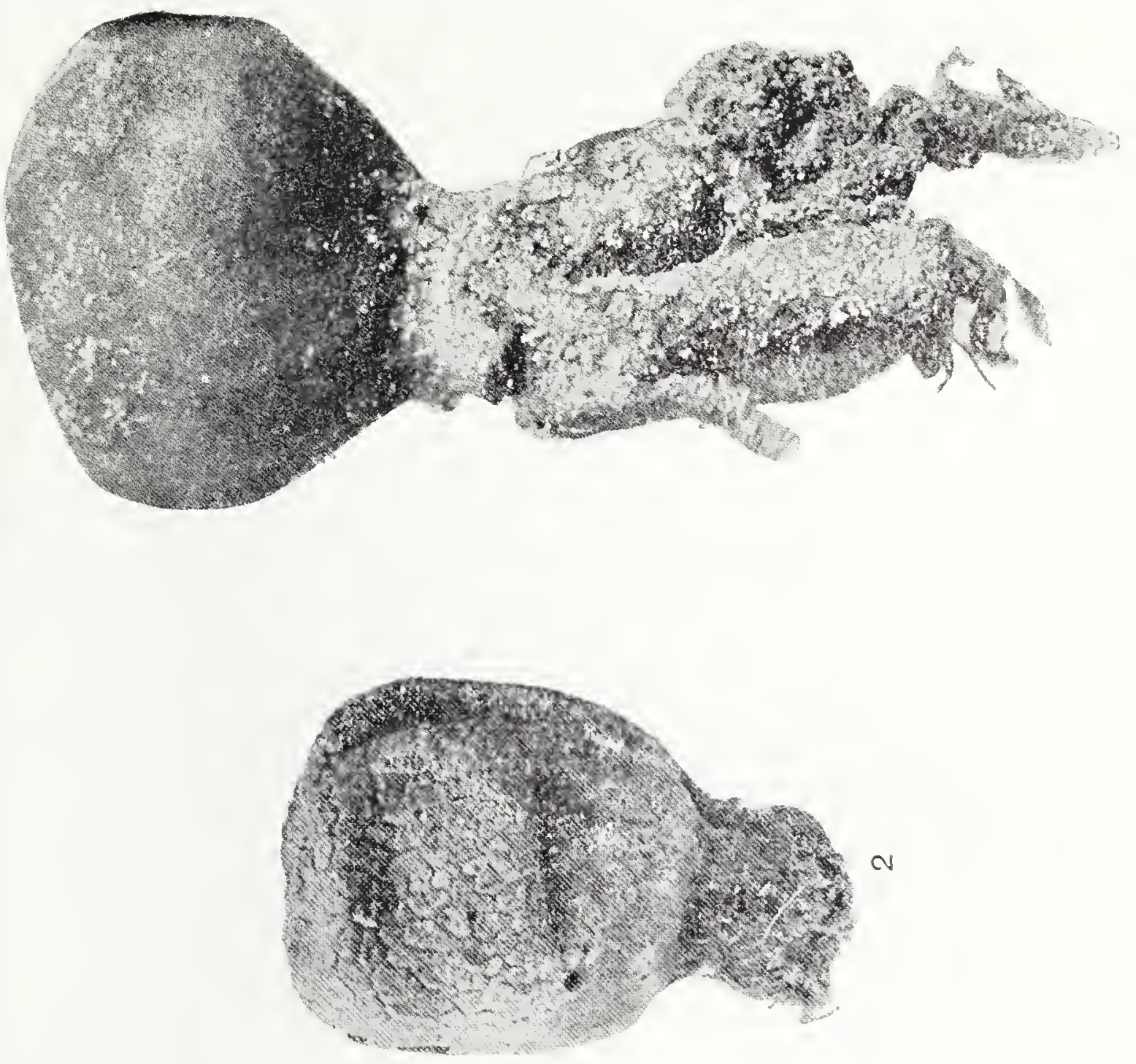

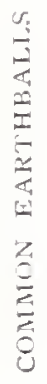

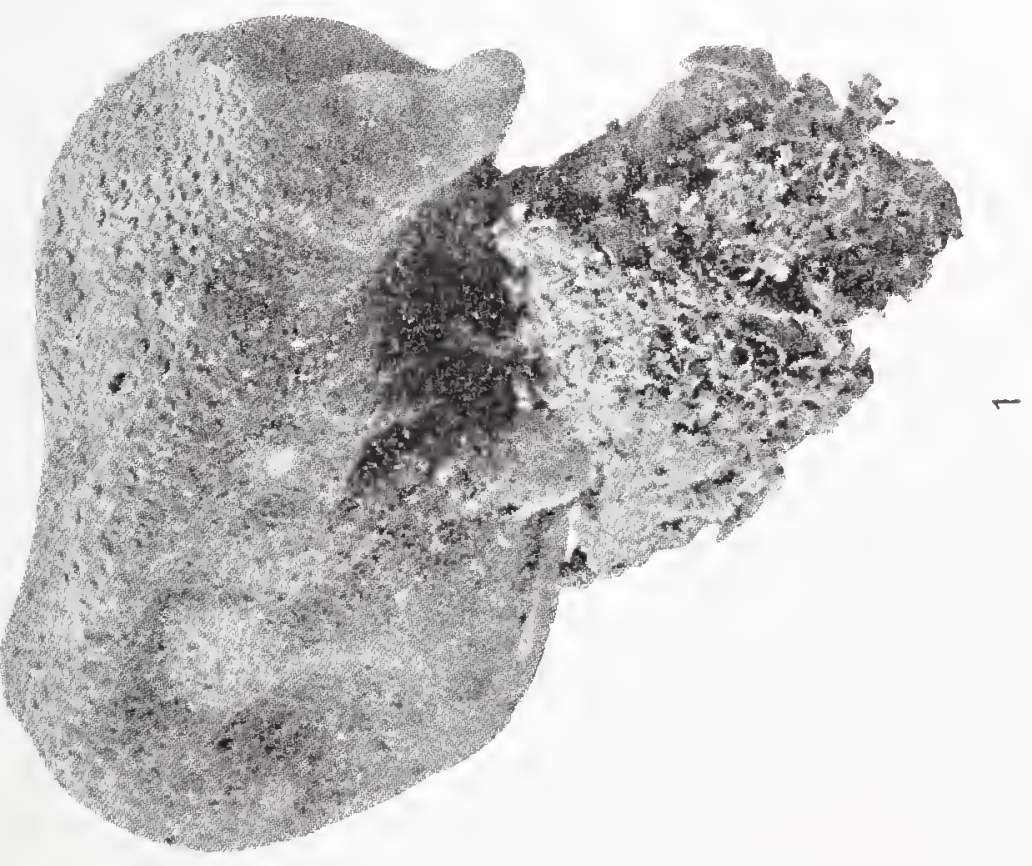




\section{DESCRIPTION OF PLATE XVIII}

\section{COMMON EARTH-BALLS}

I, Scleroderma amantium (= Sclevoderma vulgave in English textbooks), showing the thick, rigid, scaly peridium. 2, Ditto, showing the subsessile stem. 3, Scleroderma verucosum, mature plant showing the minutely warted peridium and the thick pronounced stem. (Ali natural size, after Lloyd.) 
gramulatus. The smell of $S$. vulgave is strong and disagreeable. It is rejected by pigs when searching for truffles. It is occasionally the host of Boletus parasiticus (see Plate XI.), and is sometimes attacked by a mould, Hypomyces luteo-virens.

S. verrucosum (vernucosus, full of warts-from the warted peridium), "Stemmed Earth-ball." Plate XVIII. 3.

May be easily distinguished from the preceding by the thin peridium, the long (usually), thick, lacunose stem, and the umber spore mass without a purple tinge. It is sometimes almost sessile, and might be easily mistaken for $S$. vulgave. The specific name is not a good one: it is not nearly so "warty" as the preceding species. Widely distributed, but never so frequently met with as $S$. vulgave.

Of the two remaining British species, which are by no means common, $S$. geaster may be at once recognised by the splitting of the mature peridium into stellate lobes, and $S$. bovista by the yellow trama.

\section{POLYSACCUM}

(Gr. polus, many; saccos, a bag-from the numerous small cells within the peridium)

P. pisocarpium (pisum, a pea; carpellum, a fruit-from the pea-like peridiola). Plate II. 4.

Per. 2-3 in., globose, indistinctly nodular, olive with a brown tinge, passing somewhat abruptly downwards into a stout stem about I in. long. Peridiola irregularly ovoid at first, irregularly polygonal at maturity. It has not been observed in Britain since Sowerby's time, who found one specimen amongst sand at Highgate in May.

Lloyd remarks: "The genus is close to Scleroderma, some specimens having the gleba cell walls so fragile that the plants can be taken for Scleroderma. There exists in the tissue of the peridium and walls of the peridioles a yellow 
colouring matter readily soluble in water. As it occurs in the plant it is black, but dissolved in water it is yellow. The plant is still used in the country districts of France, I am told by Monsieur P. Hariot, of the Museum of Paris, for dyeing purposes."

\section{Family NIDULARIACE㞋}

\section{(The "Birds'-nest" Fungi)}

The spores are produced in the interior of one or usually several bodies (peridiola), enclosed in a common peridium. In two genera the peridiola are attached to the "nest" by a cord, the funiculus, as it is termed. It is very elastic, and may, when wet, be easily stretched 5 or 6 ins., till it becomes as fine as a cobweb; it is brittle when dry. The peridiola are black in the four common species; they are all invested with a white membrane, the tunica, but in only one species, Crucibulum vulgave, is the membrane thick enough to mask the colour, and cause the "eggs" to appear white. The peridiola are formed by the contraction and hardening of the walls of the gleba. The species are small. They are comparatively uncommon in temperate regions, frequent in the tropics.

\section{KEY TO THE GENERA}

Cyathus. Peridiola umbilicate, attached by a cord to the wall of the peridium.

Crucibulum. Peridiola not umbilicate, attached by a cord to the wall of the peridium.

Nidularia. Peridiola not attached to the peridium.

Sphærobolus. Peridium globose, containing a single free peridiolum.

\section{CYATHUS}

(Gr. kuathos, a wine-cup--from the cup-shaped peridium)

C. striatus (from the striate inner surface of the peridium), "Striated Birds'-nest." Plate XIX. I. 

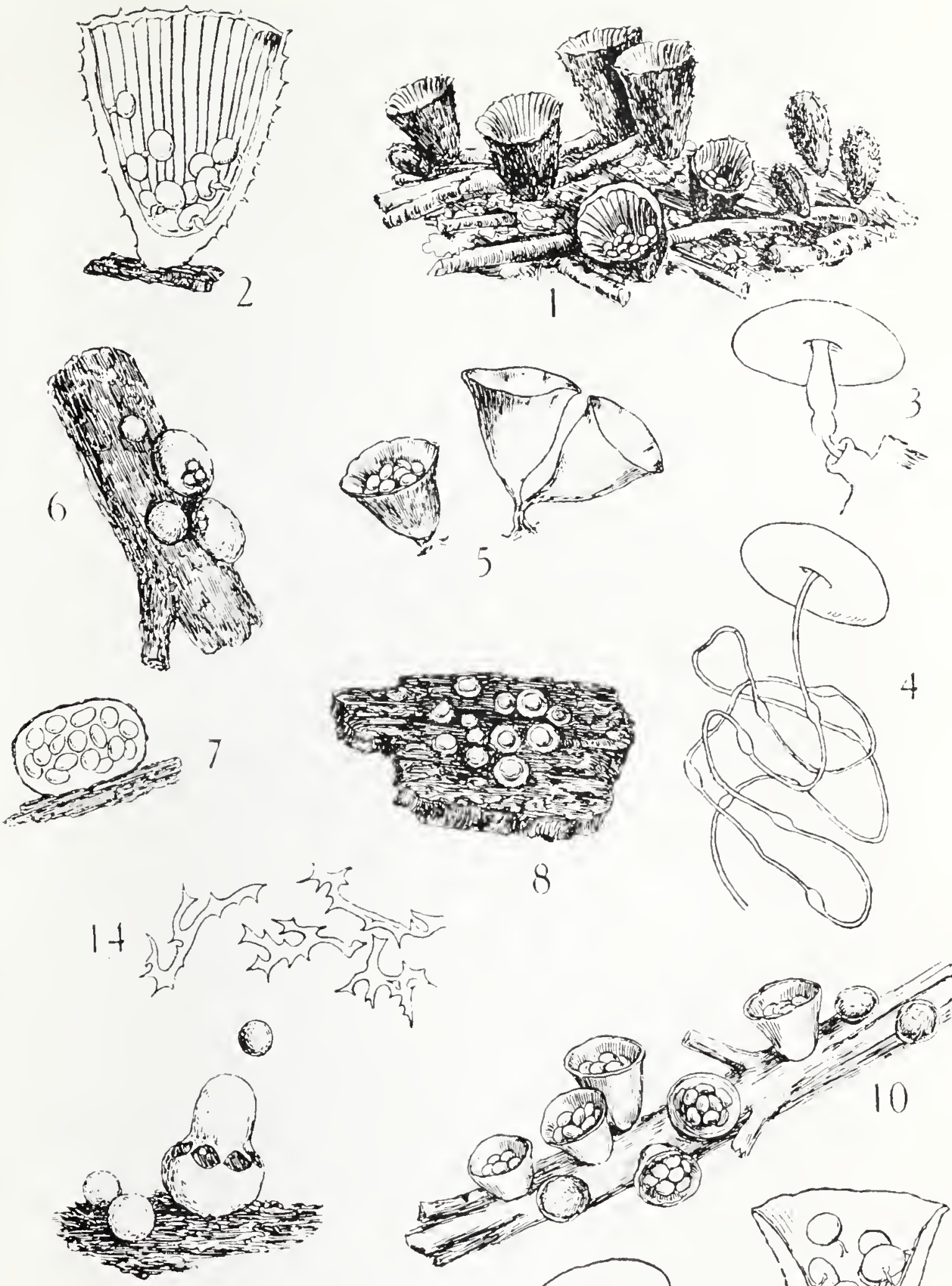

9

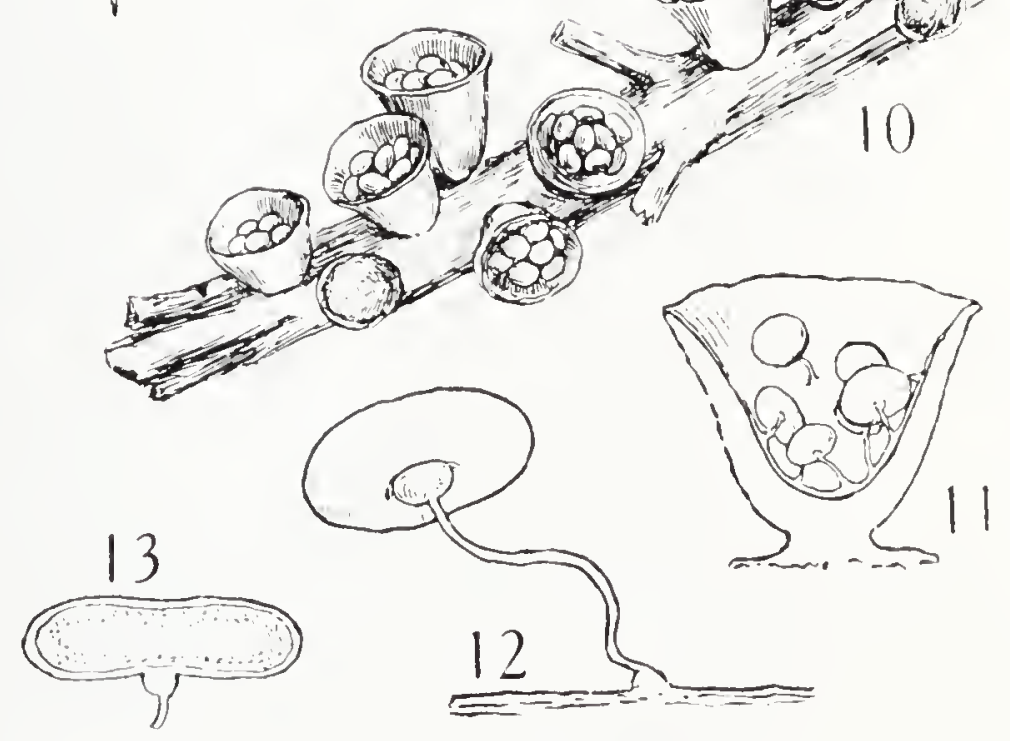




\section{DESCRIPTION OF PLATE XIX}

\section{BIRD'S-NEST FUNGI (NIDULARIACE E)}

FIG. I.-Cyathus striatus: group of plants of various ages. (Natural size.)

FIG. 2.-Ditto: section (magnified) showing peridiola attached to the wall of the peridium.

FIG. 3.-Ditto: peridiolum with funiculus and cord (magnified).

FIG. 4.-Ditto: peridiolum with the cord drawn out of the funiculus. (Magnified.)

FIG. 5.-Cyathus vernicosus.

FIG. 6.-Nidularic pisiformis: plants of various ages, slightly magnified.

FIG. 7.-Ditto: section showing the peridiola embedded in mucus.

FIG. 8.- Spherobolus stellatus: group of plants, slightly magnified.

FIG. 9.-Ditto (magnified), showing the manner in which the single peridiolum is expelled.

FIG. Io.-Crucibulum vulgare: group of plants of various ages. (Natural size.)

FIG. Ir.-Ditto (magnified), showing the peridiola attached to the wall of the peridium.

FIG. 12.-Ditto: magnified peridiolum.

FIG. I3-Ditto: section of a magnified peridiolum, showing the hymenial layer lining the interior.

FIG. I4. -Ditto: magnified hairs from the surface of the epiphragm. 
Fasciculate about $\frac{2}{3}$ in. high, on wood, twigs, etc. Hairy and brownish without, lead colour and fluted longitudinally within. The apex of the cup at first closed with an epiphragm. Frequent throughout the year. Easily known by the striæ, or lines, just within the top of the cup; these are not present in any other European or American species. The American form of this species is the more brightly coloured.

C. vernicosus (vernicosus, shining as if varnished-from the appearance of the outer surface of the peridium), "Shining Birds'-nest." Plate XIX. 5.

Campanulate, smooth, clustered, about $\frac{1}{2}$ in. high, broadly open at maturity. Usually growing on bare soil, rarely on wood. The cups are firmer and thicker than those of the preceding species and are smooth inside. The peridiola are larger than those of any other species of the Nidulariaceæ. The commonest European species.

\section{CRUCIBULUM}

(From a supposed resemblance to a crucibulum, a small melting-pot)

C. vulgare (from its commonness), "Common Birds'-nest." Plate XIX. Io.

Pev. $\frac{3}{8}$ in. high, thick, greyish-white or yellowish, bleaching with age, the mouth ( $\frac{1}{4}$ in. across) at first closed with a yellowish epiphragm; smooth and shining within, minutely hairy without. The cups are more saucer-shaped than those of other species. Sometimes young cups appear within the old ones. Gregarious; frequent on rotten wood, decaying bracken and bramble stems, etc., in late aut.

\section{NIDULARIA}

(From a supposed resemblance to a nest, nidus)

N. pisiformis (pisum, a pea; forma, shape-from the pea-like form of the peridium). Plate XIX. 6 . 
Per. about $\frac{1}{4}$ in. high and broad, cinnamon or buff, split. ting irregularly. Peridiola subrotund, brown and shining, becoming wrinkled when dry. Solitary or gregarious, terrestrial, or on wood and leaves. Sum. and aut. Rare.

\section{SPHAROBOLUS}

(Gr. sphaira, a ball; ballo, to throw-in reference to the ejection of the peridiolum)

S. stellatus (from the stellate mouth of the peridium), "Catapult." Plate XIX. 8.

Per. $\frac{1}{10}$ in. diam., pale yellow, tomentose, splitting into 5-7 bright orange segments. Crowded on wood, twigs, rotten grass, etc. May be found throughout the year. The numerous peridia are at first connected by a cobwebby mycelium. Unique in the peculiar method of spore dispersal (see p. I7).

\section{Family LYCOPERDACE㘴}

\section{(The Puff-balls and Earth-stars)}

KEY TO THE GENERA

Lycoperdon. Endoperidium flaccid, opening by a small terminal aperture. Sterile base present or absent. Spores not pedicellate.

Calvatia. Endoperidium flaccid, flaking away in patches. Sterile base present.

Bovistella. Endoperidium flaccid, opening by a small terminal aperture. Sterile base present or absent. Spores pedicellate. Mature plant normally attached to the matrix by a strong rooting system.

Bovista. Endoperidium firm, opening by a small terminal aperture. Sterile base absent. Mature plant loosened from the place of growth.

Geaster. Exoperidium splitting in a star-like manner

Tulostoma. Stem elongated, slender. Peridium subglobose, opening by an apical mouth.

Queletia. Stem elongated, stout. Peridium subglobose, opening irregularly.

Batarrea. Stem elongated, slender. Peridium compressed. 


\section{DESCRIPTION OF PLATE XX}

TIVO COMMION PUFF-BALLS

FIG. I. - Cortex or outer skin of Lycofordon echinatum, enlarged four times, showing the long curved spines arranged in bundles. The tips in each bundle are gathered together, and form more or less of a point; the spines are separate at the base, and are surrounded by a tessellated group of brown warts.

FIG. 2,-Cortex of Lycoperdon gemmatum, enlarged four times, showing the peculiar arrangement of the consolidated warts.

FIG. 3.-Lycoperdon gemmatum, natural size, showing the soldered warts.

Fig. 4.-Lycopcrdon cchinatum, natural size, showing the crowded spines. (All after Lloyd.) 

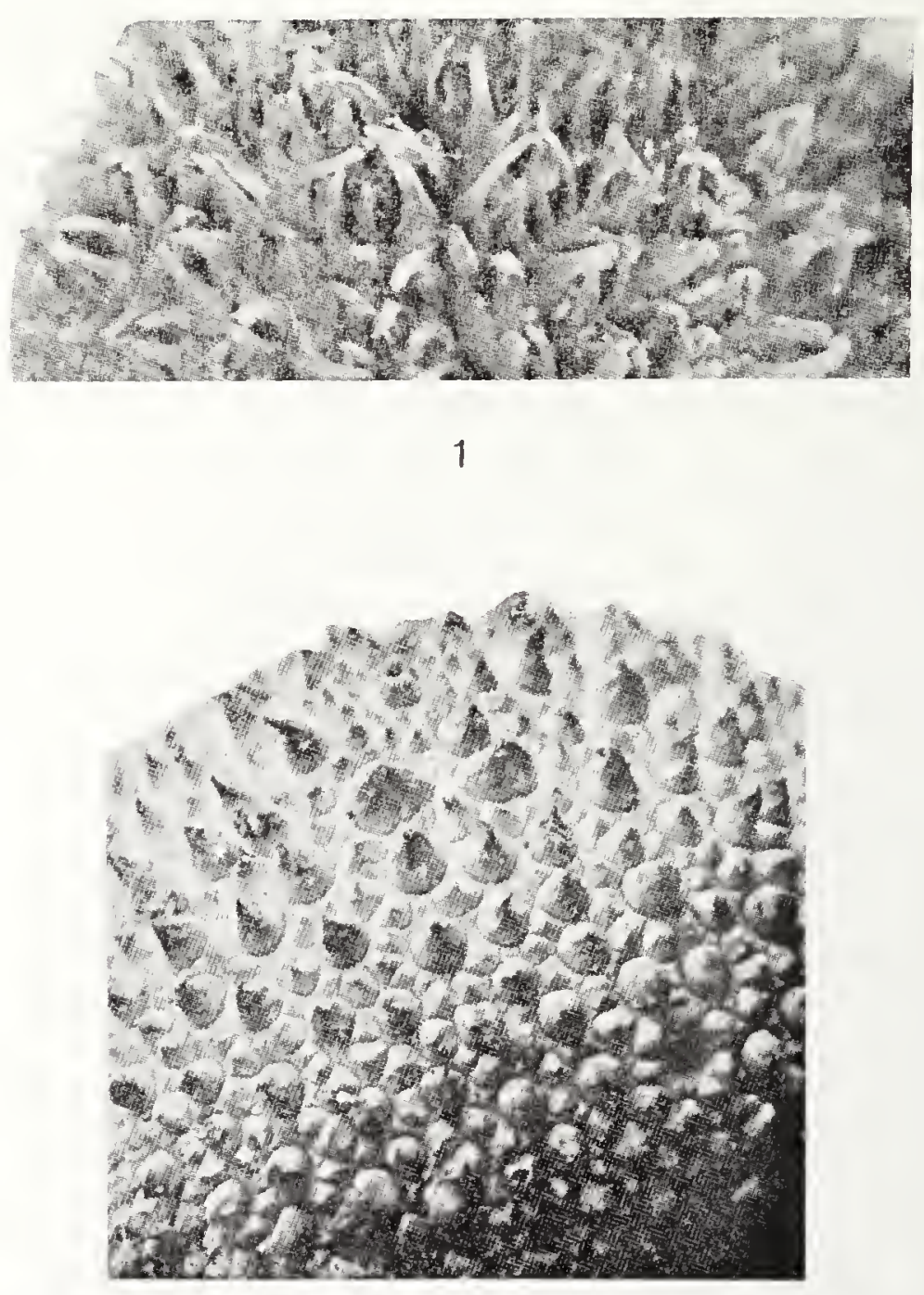

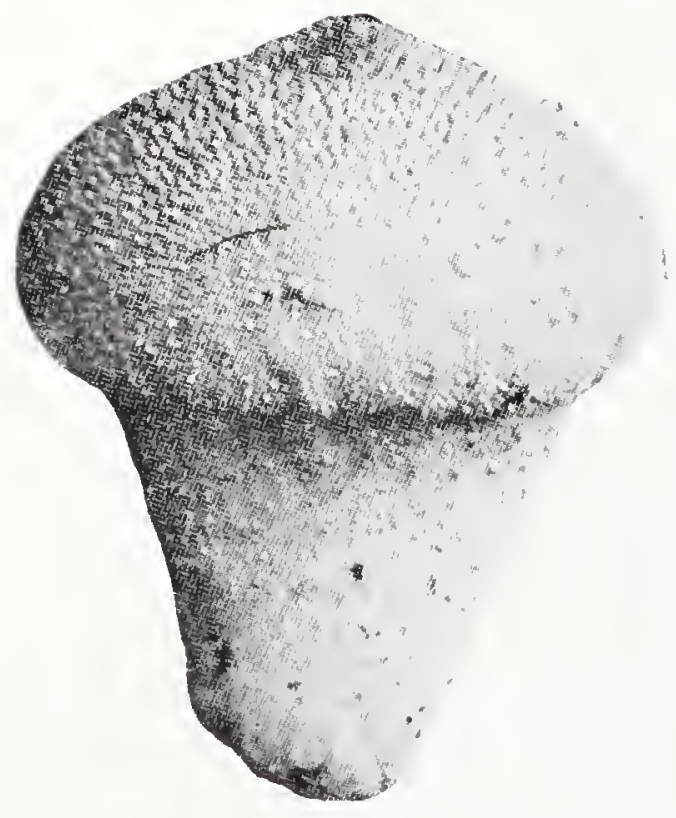

3

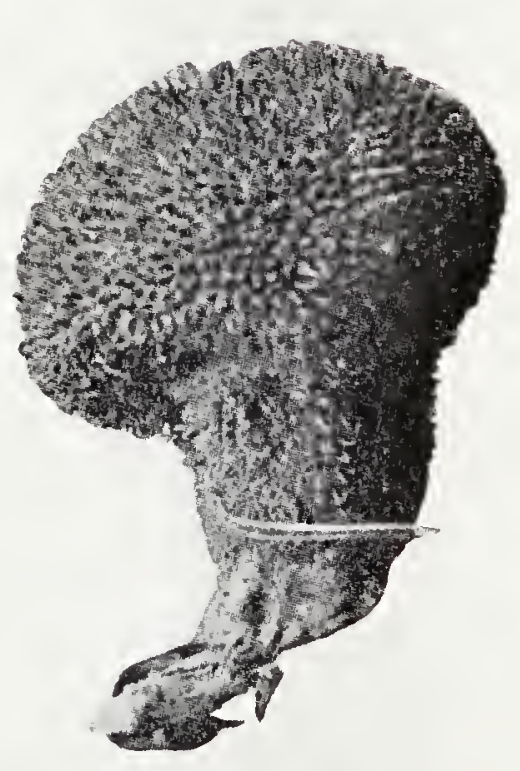

4

TWO COMMON PUFEBALISS 


\section{LYCOPERDON}

(Gr. lukos, a wolf; perdon, dung-from an old belief that puff-balls grew from the dung of the wolf)

L. echinatum (echinus, a hedgehog-from the large spines investing the peridium), "Hedgehog Puff-ball." Plate XX. 4 .

Per. subglobose, I-2 in. high and broad, covered with long purple-brown spines, each of which is surrounded by a circle of brown warts. At maturity the spines fall away and the surface appears tessellated. Opening irregular. Sterile base well developed, yellowish. Mycelial strands long and white. Spore mass purple umber. Frequent amongst leaves in woods (chiefly beech) in ant., usually solitary.

L. Hoylei (after Mr. Hoyle) differs chiefly in the bright yellow basal stratum, and L. atropurpureum in the purplishbrown basal stratum.

I. gemmatum (gemma, a bud-from the pointed warts investing the peridium). Plate XX. 3 .

Pev. subglobose, 3-4 in. high, I-2. in. diam., covered with flattened soldered warts; spines pointed, brown. Sterile base cellular, passing down into a thick stem. Spore mass olivaceous umber. Common in open places in woods in ant.

L. perlatum (perlatus, very wide-from the great width of the peridium in comparison with the stem) differs in having the exoperidium covered with long fragile caducous spines, surrounded at their bases by circles of short warts. It is frequently umbonate, and springs in pairs from the same base. Occurring in troops in shady woods, particularly under conifers.

L. pyriforme (pyrus, a pear ; forma, shape-from the pearshaped peridium) forms dense tufts (usually) on rotten stumps and branches, springing from white cord-like mycelium. The only puff-ball that grows exclusively on wood. The var. excipuliforme (from a supposed resemblance 
to a basin, excipula) differs in the abrupt contraction of the peridium into a slender stem. It is the Lycoperdon Desmazieves of American mycologists.

\section{CALVATIA}

(From the resemblance of some species to a bald scalp, calva)

c. saccata $=$ Lycoperdon saccatum (saccus, a bag-from a supposed resemblance to an inverted sack).

Pev. 2-5 in. high, I-3 in. across, spherico-depressed, plicate below, the upper part flaking away at maturity. Spore mass olivaceous umber. The sterile base is continued downwards as a stout elongated stem $2.4 \mathrm{in}$. long, often more or less lacunose. Sometimes the measurements much exceed those given above. Open places in and bordering woods in aut., often growing in large loose rings.

C. cælata = Lycoperdon calatum (calum, a sculptor's chiselfrom the appearance of the warts of the peridium, as if carved in bas-relief), "Sculptured Puff-ball." Plate XXI. 4.

Pev. 2-7 in., obovoid or depressed, tapering downwards, more or less covered at first with a thick floccose layer of densely coalescent warts, which break up into scattered conical warts. Spore mass olive, with a lilac tinge. Fields and open places in woods, usually in twos and threes. Easily recognised by the tessellated appearance after the warts have fallen away. There is sometimes a long tapering root.

C. gigantea $=L y c o p e r d o n$ gigantenm or bovista (from its resemblance to a Bovista), "Giant Puff-ball."

Pev. globose or depressed, 4-I 2 in. or more across, white, slightly hairy, then smooth like kid leather, flaking away at the top. Spore mass yellow at first, olive at maturity. In grassy places in aut., local. The largest of our puff-balls. It sometimes occurs in rings up to $40 \mathrm{ft}$. in diam. The largest known specimen is recorded from America; it was $5 \mathrm{ft} .4$ in. in its greatest diam., but only $9 \frac{1}{2}$ in. high. There 


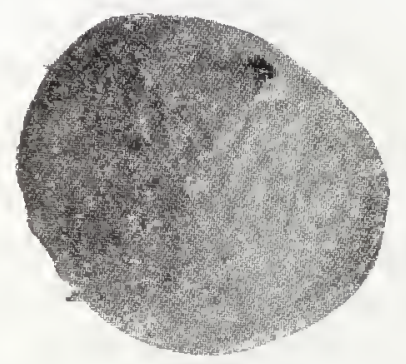

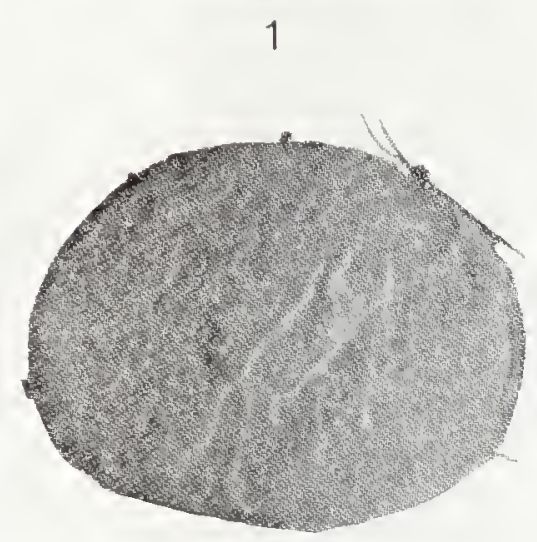

2

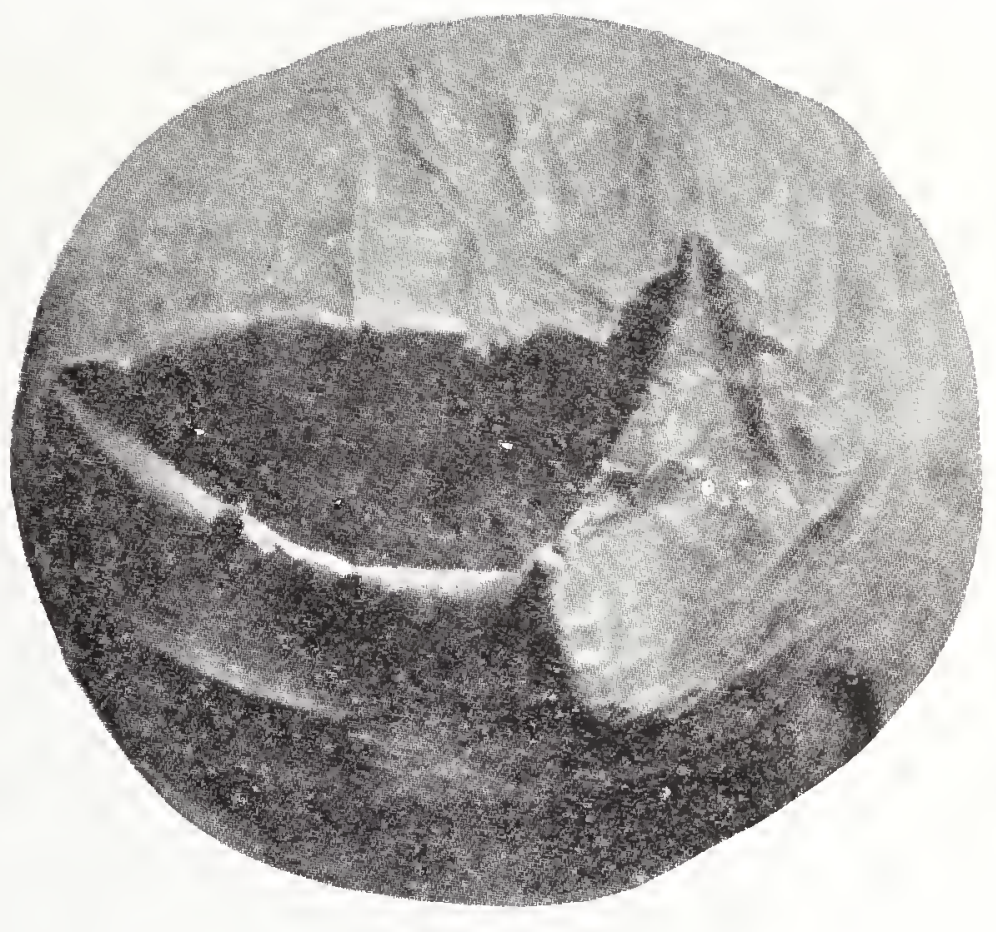

3

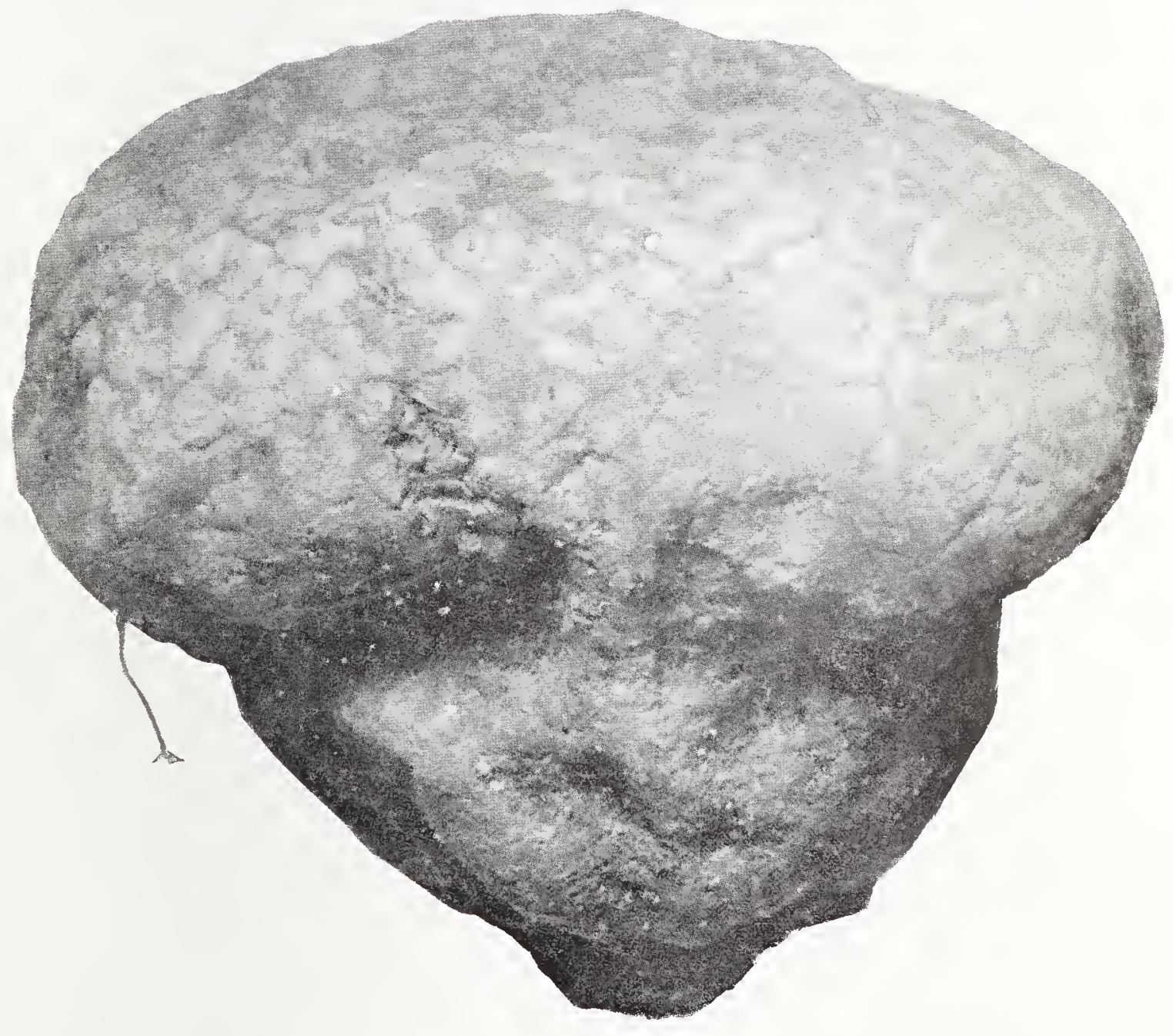




\section{DESCRIPTION OF PLATE XXI}

\section{SOME TYPICAL PUFE.BALLS}

Fig. I. - Bovista plumbea (=Lycoperdon flumbeum in Massee's "British Fungus Fiora"): mature plant, in which the exoperidium has fallen away.

FIG. 2. - Section of a young Bovista flumbea, showing the absence of a sterile base.

FIG. 3.-Bovista nigrescens (= Lycoperdon nigrescens): mature plant. The thin outer layer has fallen away; the thin, tough, shining skin well shown in the illustration is the inner layer.

FIG. 4-Calratia colata (= Lycoperdon crelatum in Massee's "British Fungus Flora"): mature plant, showing the characteristic tessellated appearance of the peridium, the flattened warts being surrounded by a meshwork of furrows. (All natural size, after Lloyd.) 
is a record in the Gardener's Chronicle (1884) of an English example $5 \mathrm{ft} .4$ in. in circumference. I have seen specimens in apple orchards in East Somerset $2 \mathrm{ft}$. in diam.

\section{BOVISTELLA \\ (Diminutive of Bovista)}

B. paludosa (paludes, bogs-from its habitat).

A small species with subglobose reddish-brown, scurfy, thin peridium (plicate below), contracted into a distinct stemlike base. Sterile base pronounced. Gleba dark olive. Spores pedicellate. This interesting species was added to the British fungus flora in August, I908, when Mr. T. Gibbs gathered it on the moors, Cleveland Hills, Yorkshire. Hitherto known only from Malesherbes, France, where it was gathered in 1845 . It occurs on sphagnum moss in bogs.

\section{BOVISTA}

(Bofist, a fairy-ball, the German popular name*)

B. plumbea $=L y c o p e r d o n$ plumberm (plumbers, leaden-from the colour of the endoperidium). Plate XXI. I.

Per. globose, about 2 in. high and broad, outer layer thin and whitish, breaking away above, and exposing the thin, tough, persistent, lead-coloured inner one. Spore mass umber-brown. Frequent in sum. and aut. in dry pastures and healthy places.

B. nigrescens $=L y c o p e r d o n$ nigrescens (nigrescens, turning black-from the blackish endoperidium), "Black Puff-ball." Plate XXI. 3.

Per. globose, about 2 in. high and broad, outer layer whitish, soon breaking away and exposing the tough, persistent, shining blackish-umber inner one. Spore mass

* Dr. Plowright says that the term "puff-ball" is not used in Norfolk: the Lycoperda are there popularly known as "bulvers," " bullfists, " or "fuzzy-balls." 
umber, with a decided purple tinge. Frequent in dry pastures and heathy places.

B. pusilla $=L y c o p e r d o n$ pusillum (pusillus, small-from its small size).

Per. less than I in. high and broad, subglobose, pale yellowish-brown, breaking up into minute scurfy squamules and becoming smooth. Spore mass olivaceous ochre. In pastures and hedge-banks. Our smallest puff-ball.

\section{GEASTER}

(Gr. ge, the earth; aster, a star-from the star-like appearance of the mature plant)

G. coliformis = Myriostoma coliformis (colum, a colanderfrom the appearance of the endoperidium), "Colander Earth-star." Plate XXII. I.

Outer per. 7-Io segmented, 3-5 in. diam. when expanded. Inner pev. subglobose, supported on several more or less confluent short stalks, which sometimes extend upwards to form columellæ. Orifices many. Spore mass umber. In aut. in sandy places; rare in Britain; said to be abundant on the plains of Hungary. Lloyd remarks that the inner peridium, with its several mouths, can be, not inaptly, compared to a "pepper-box." $\mathrm{He}$ is wrong in supposing that the word "colander" is "almost obsolete" in this country; a colander finds a place in every kitchen!

G. Bryantii (after Charles Bryant), "Bryant's Earthstar." Plate XXII. 2 and 3.

Outer per. 8-I2 segmented, becoming recurved; pale

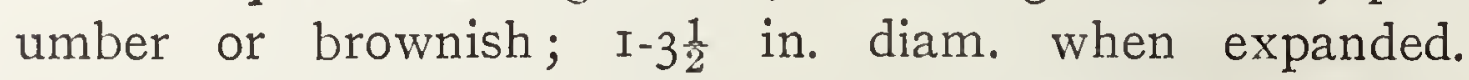
Inner per. subglobose, with a distinct groove around it at the base, where it joins the slender pedicel; dark purplishslate colour. Orifice long and conical. Spore mass dark brown. Amongst leaves and in sandy hedge-banks, appear. ing in sum. and lasting till spr. Rare. 


\section{DESCRIPTION OF PLATE XXII}

\section{SOME RARE EARTH-STARS}

FIG. I. - Myriostoma coliformis (=Geaster coliformis): mature plant, showing the lobed exoperidium, the inner peridium supported on more or less confluent stalks, and two of the round, slightly elevated mouths from which the spores escape.

FIG. 2.-Geaster Bryantii, showing the circular groove at the junction of the inner peridium with its slender pedicle.

FIG. 3.- Ditto, showing the sulcate, beaked mouth.

FIG. 4.--Geaster rufescens, an unexpanded plant, resembling a puff-ball.

FIG. 5.-Ditto: mature plant, showing the cracked surface of the fleshy layer.

FIG. 6.-Geaster limbatus: mature plant, showing the constricted inner peridium. This species is black; $G$. vufescens is reddish-brown. (All natural size, after Lloyd.) 
G. limbatus (limbatus, bordered as with another colour-from the fringed peristome), "Black Earth-star." Plate XXII. 6.

Outer per. cut into many segments, blackish-brown, 3-4 in. diam. when expanded. Inner per. subglobose, usually constricted in a peculiar manner. Columella almost or quite obsolete. Orifice conical, surrounded by a pale silky zone. Spore mass purple-brown. In fir woods and hedge-banks in aut. Rare.

G. fornicatus (fornicatus, arched over from the arched inner layer of the exoperidium), "Arched Earth-star." Plate XXIII. 9.

Outer per. divided into 4 (rarely 5) segments, $1 \frac{1}{2}-2 \frac{3}{4}$ in. diam. when expanded. The fibrillose layer becomes torn away and arches itself above the cup-like mycelial layer, to which it remains attached by the tips of the segments. Inner per. shortly stalked, urn-shaped. Orifice conical. Spore mass dark brown, with a purple tinge. In fields and amongst firs on heaths, March to Nov. Rare.

An allied species, G. coronatus, common in pine woods in Europe, especially Sweden, should be looked for in this country. It differs from $G$. formicatus in the broadly rounded shoulder of the arched segments, the imperfect cups formed by the mycelial layer, and in having the inner peridium covered with minute granular particles.

G. mammosus (mamnosus, full-breasted-from the breastlike endoperidium). Plate XXIII. 5-7.

Outer per. 7-Io segmented, I-2 in. diam. when expanded, brownish or umber. Inner pev. globose, whitish-brown. Orifice conical, even, surrounded by a pale silky depressed zone. Spore mass dark brown, with a purple tinge. A markedly hygroscopic species, easily known from others exhibiting this peculiarity by the even conical mouth. Rare.

G. rufescens (from the rufescent colour at maturity), "Red Earth-star." Plate XXII. 4 and 5.

Outer per. 6-9 segmented, thick, becoming deeply cracked, 
and resembling rough, reddish leather; $2-4$ in. diam. when expanded. Inner per. globose, pale to dark umber. Orifice slightly mammiform, often torn. Spore mass blackishbrown. Differs from $G$. limbatus in the prominent, persistent columella and the red-brown colour. Woods and pastures, aut. and early win. Rare.

G. fimbriatus (from the sometimes fimbriated mouth of the peristome). Plate XXIII. 8.

Outer pev. usually 6-8 segmented (sometimes I5), the segments extending about halfway, slightly recurved when expanded, with a tendency to split into two layers; $I \frac{1}{2}-2 \frac{1}{2}$ in. diam.; buff or umber-white, with whitish cracks. Inner pcr. sessile, subglobose, pale umber. Orifice indeterminate, fibrillose. "The idea that fimbriatus can be known by its 'fimbriate' mouth is an error. The mouth does not differ from several other species with indeterminate mouths" (Lloyd). Spore mass blackish-umber. In pine woods in late aut. and early win.

G. hygrometricus (Gr. hugros, moisture; metron, a measurefrom its absorption of moisture from the air), "Hygroscopic Earth-star." Plate XXIII. I-4.

Outer per. 7-20 segmented, $I \frac{1}{2}-2 \frac{1}{2}$ in. diam. when expanded, horny, yellowish-brown, often cracked all over. Inner per. sessile, ovato-globose in section, floccose, crimson-brown or purple-lavender. Orifice narrow, irregularly torn. Columella obsolete. Spore mass dark brown. It develops under the ground, and is of very slow growth. Care must be taken not to mistake an unexpanded specimen for an undeveloped puff-ball. Various genera have been based on unexpanded earth-stars. Lloyd remarks: "The plant ripens in late sum. or fall of the year, and the thick outer peridium splits into segments, sometimes as few as four, sometimes as many as twenty. They are strongly hygroscopic, and in moist weather recurve, and, standing on their tips, lift up the inner ball. In dry weather they closely curve in, clasping 


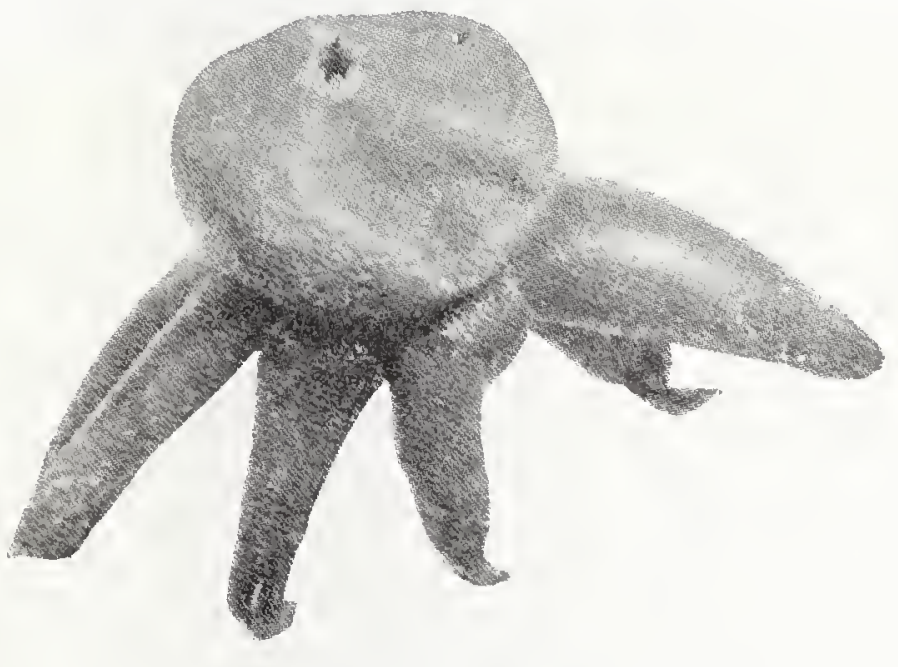

3

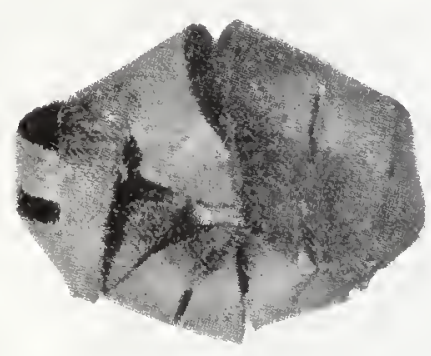

5

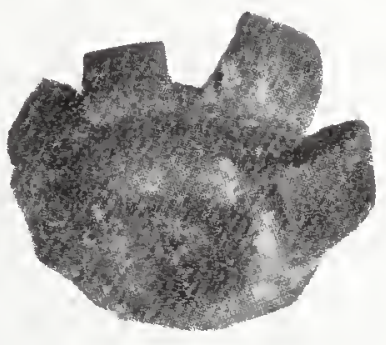

6

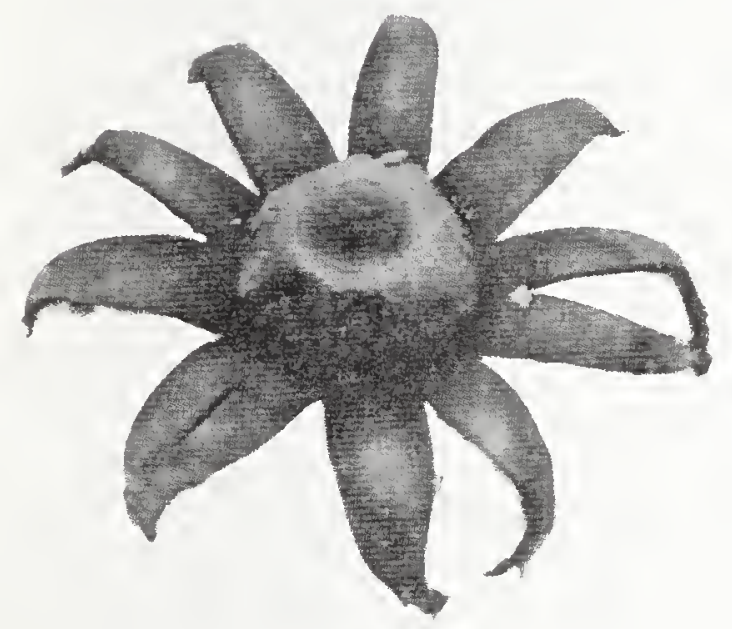

7

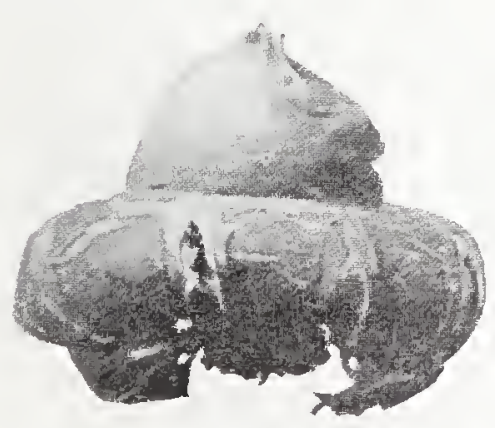

8

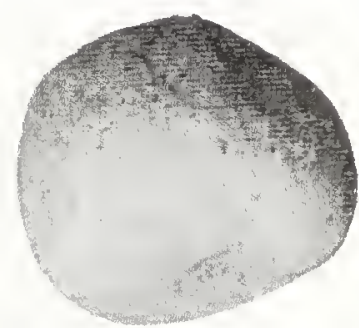

1

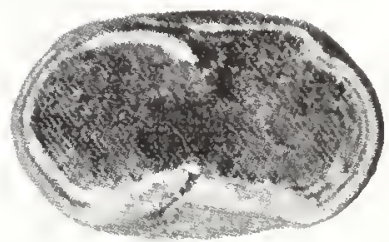

2
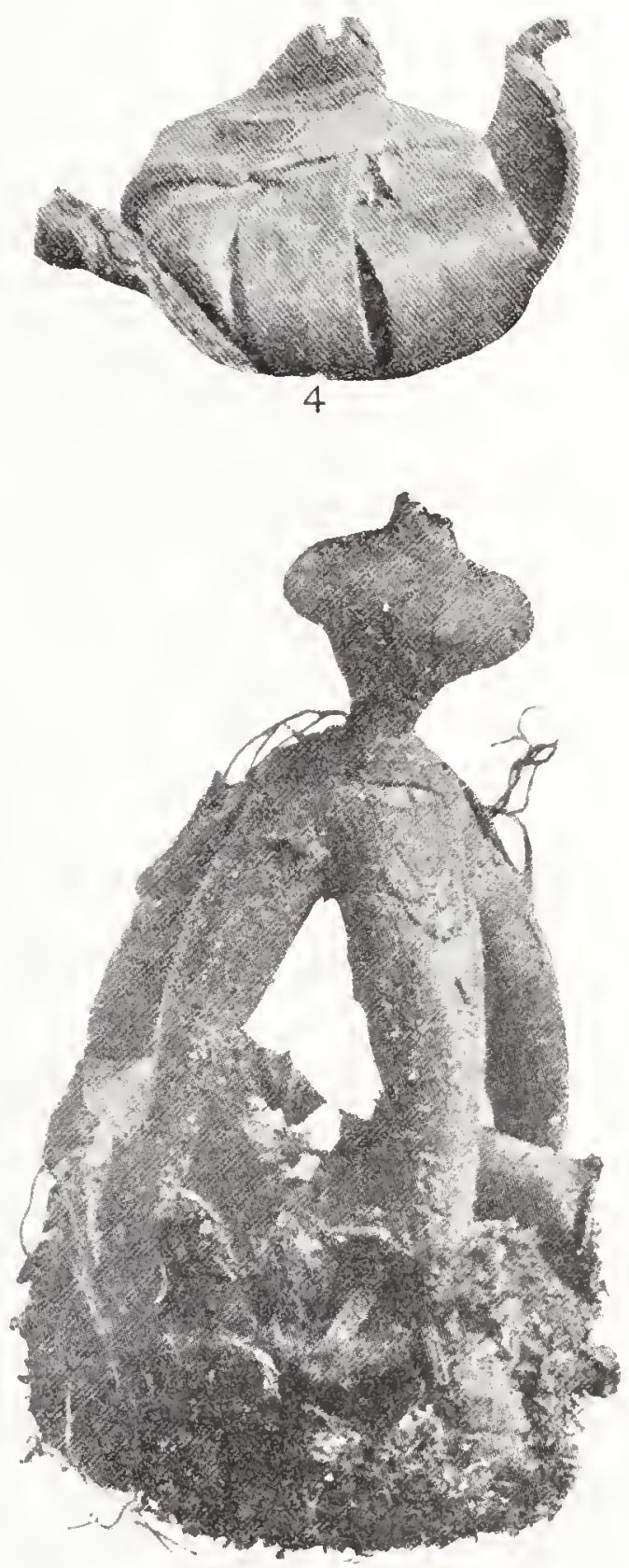

EARTHSTARS (GEASTRAE) 


\section{DESCRIPTION OF PLATE XXIII}

\section{EARTH-STARS (GEASTR无)}

FIG. I.-Geaster hygrometricus : globose unexpanded plant, resembling a young puff-ball.

FIG. 2.- Section of the same.

FIG. 3.-G. hygrometricus: mature expanded plant, showing the segments of the outer peridium, and the thin, stalkless, globose, inner peridium, with a torn aperture at its summit for the escape of the spores.

FIG. 4.-G. hygrometricus: a dry specimen, showing the strongly incurved segments.

FIG. 5.-G. mammosus, unexpanded, showing the upper surface.

FIG. 6.-Ditto, showing the umbilicate base.

FIG. 7.-G. mammosus: mature expanded plant. The exoperidium is divided almost to the base into many segments. The globose, sessile endoperidium has a protruding mouth seated on a definite area.

FIG. 8. - G. fimbriatus: mature plant, showing the recurved segments of the exoperidium, the segmentation extending about halfway.

Fig. 9. - G. formicatus, showing the fornicate exoperidium arched over the separated mycelial layer, which remains as a cup on the ground, and attached to it. by the tips of the segments. (All natural size, after Lloyd.) 
the ball, and they will repeat this as often as the conditions become moist or dry; hence they are called 'hygrometricus,' and frequently by children 'poor man's weatherglass.' Miss Marshall states that in the closed condition they are carried along by the wind, and applies to them the name of 'fair-weather travellers.' Plants persist often during win., and one observing them in the spr. expanding under the influence of moisture may take them for growing plants. They become 'weather-worn,' the inner surface of the exoperidium cracked in numerous area, the surface of the inner peridium frayed and fibrillose."* A cosmopolitan species frequenting sandy pine woods, not so common in England as on the continent of Europe.

\section{TULOSTOMA}

(Gr. tulos, cartilage; stoma, mouth-from the structure of the mouth of the peridium)

T. mammosum (mamma, a breast-from the breast-like peridium), "Little Wall-loving Puff-ball." Plate II. 2.

$P e v \cdot \frac{1}{2} \cdot \frac{2}{3}$ in. diam., globose, minutely umbonate at first, at maturity rupturing at the umbo to allow of the escape of

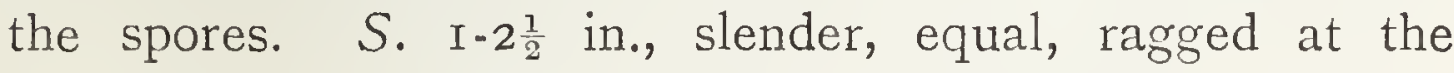
base with the remains of the rolva, generally clad with minute scales. W. G. Smith says there are two well-marked forms-brown with a stout stem, and yellowish-white with a slender stem-but intermediate ones occur. Amongst moss on old dry walls and banks in aut. and wim., chiefly in the eastern counties.

\section{QUELETIA}

\section{(After Dr. Lucien Quélet)}

Q. mirabilis (mirabilis, wonderful-from its peculiar shape). Per. $2 \frac{1}{4}$ in., thin, even, fragile, flaking away when adult, whitish at first, then greyish. S. about 5 in. long, nearly $2 \mathrm{in.}$ * "The Geastræ," by C. G. Lloyd, Igor, pp. 9, ro. 
in maximum thickness, somewhat swollen and brownish below, whitish above, densely scaly. Gregarious, at first wholly subterranean. Very rare.

\section{BATARREA \\ (After Antonio Battarra)}

B. phalloides (from its resemblance to Phallus):

Pev. I-I $\frac{1}{2}$ in., concavo-convex, with the convex side above, orange-brown. S. IO-I4 in., slender, slightly tapering downwards, hollow; externally broken up into coarse fibres, which point downwards, with a loose volva at the base, the colour of the peridium. $V$. ovate, consisting of two white membranes, enclosing a gelatinous olive-yellow layer. In and near decaying ash-trees on sand-hills, aut. and win. At first enveloped in the volva and buried deep in the ground. Very rare, occurring in the eastern counties of England.

\section{Family PHALLOIDACE}

(The Stinkhorn Fungi)

IEY TO THE GENERA

Phallus. Pileus free; joined only at its apex to the stem-like receptacle.

Mutinus. Pileus adnate and continuous with the stem-like receptacle. Lysurus. Pileus divided into vertical lobes at the apex of the stemlilie receptacle.

Clathrus. Receptacle forming a hollow globose net.

\section{PHALLUS}

(From its phallic resemblance)

P. impudicus (impudicus, shameless), "Common Stinkhorn." Plate XXV.

$P$. reticulated externally, at first covered with an olivebrown mucus. Receptacle (=the "stem") elongated, spindle-shaped. About the size of a hen's egg before the rupture of the volva, from 5 to ro in. high when fully de. 

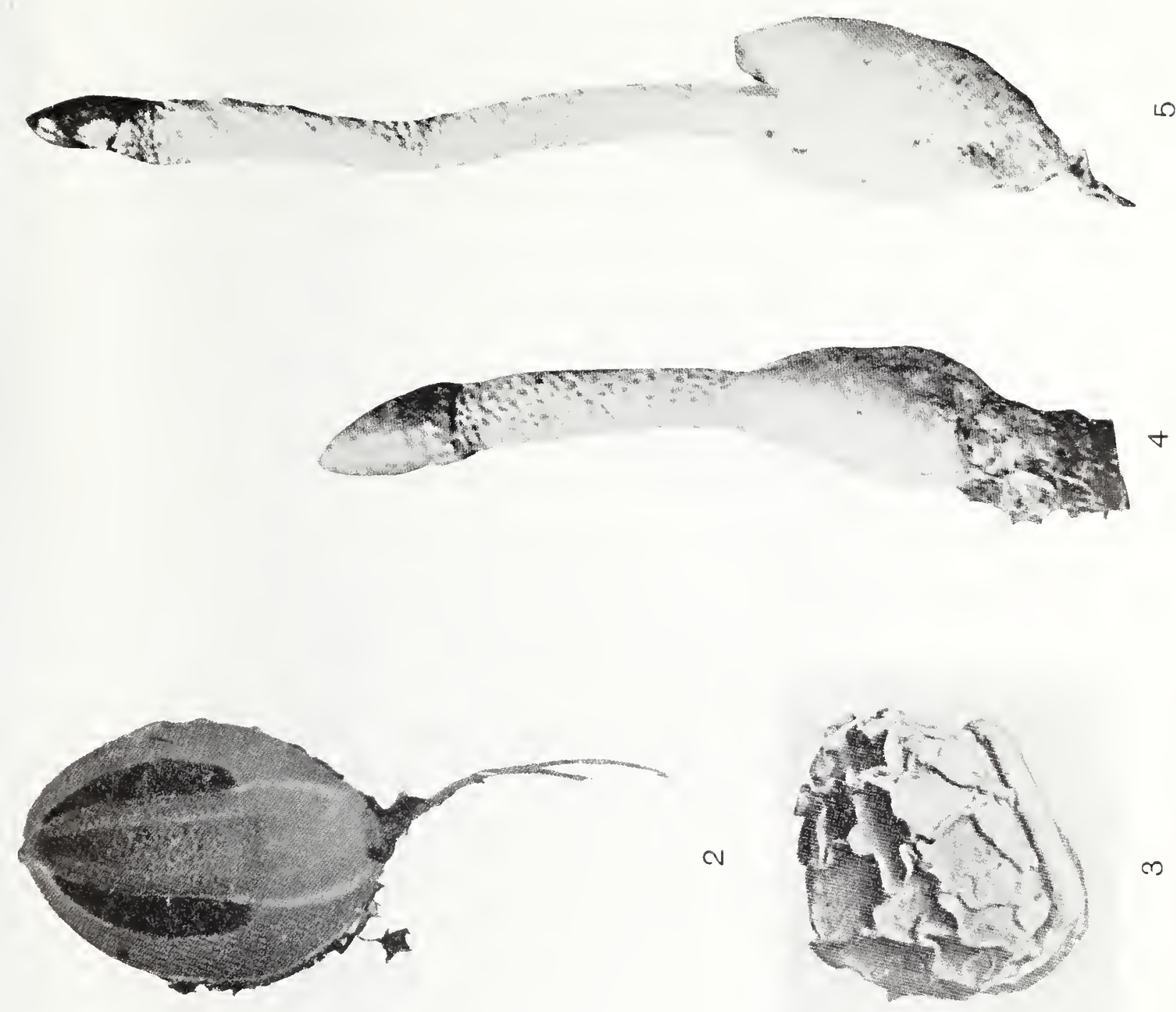

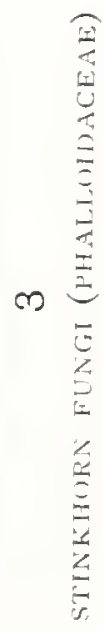

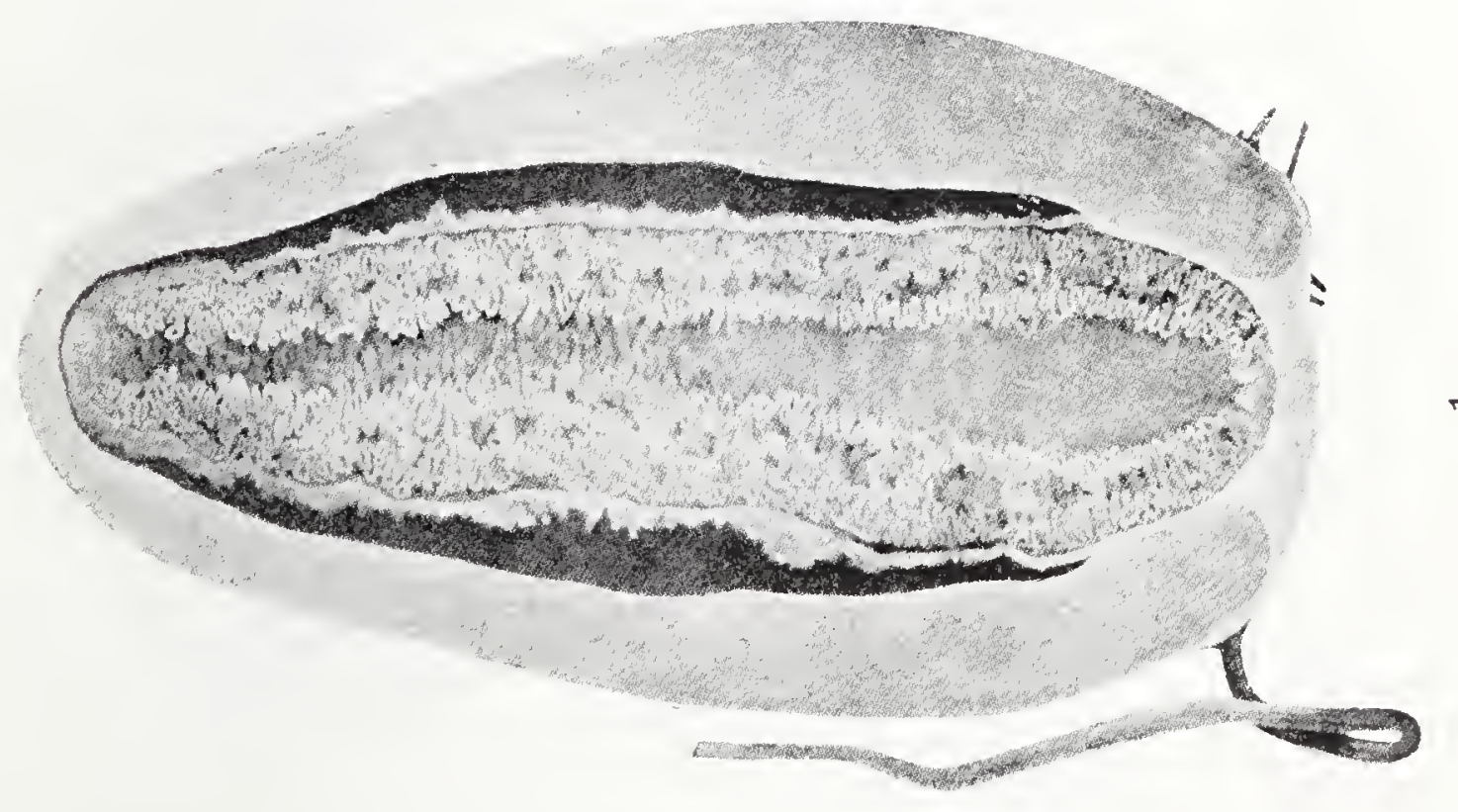




\section{DESCRIPTION OF PLATEXXIV STINKHORN FUNGI (PHALLOIDACEE)}

FIG. I.-Enlarged section (three diameters) of an "egg" of Phallus aurantiacus, showing the compressed cells, which very rapidly elongate as the plant develops. The mechanism may be compared with that of a "Jack in-the-box." (See also Plate III.)

Fig. 2.-Section of a Mutinus "egg" just prior to the bursting of the volva.

FIG. 3.-A dried phalloid "egg," showing the pronounced polygonal ridiges.

FIG. 4.-Mutinus caninus approaching maturity.

Fig. 5. - Mature plant of Mutmus canimus, showing the pileus adnate to the slender stem. (All after Lloyd, 2-5, natural size.) 


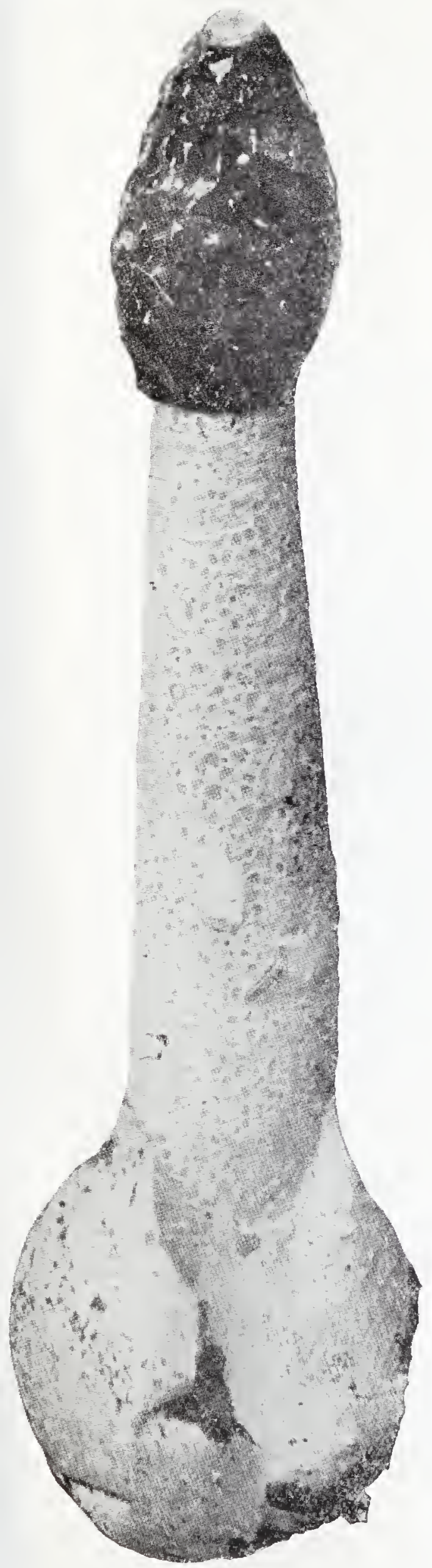

3
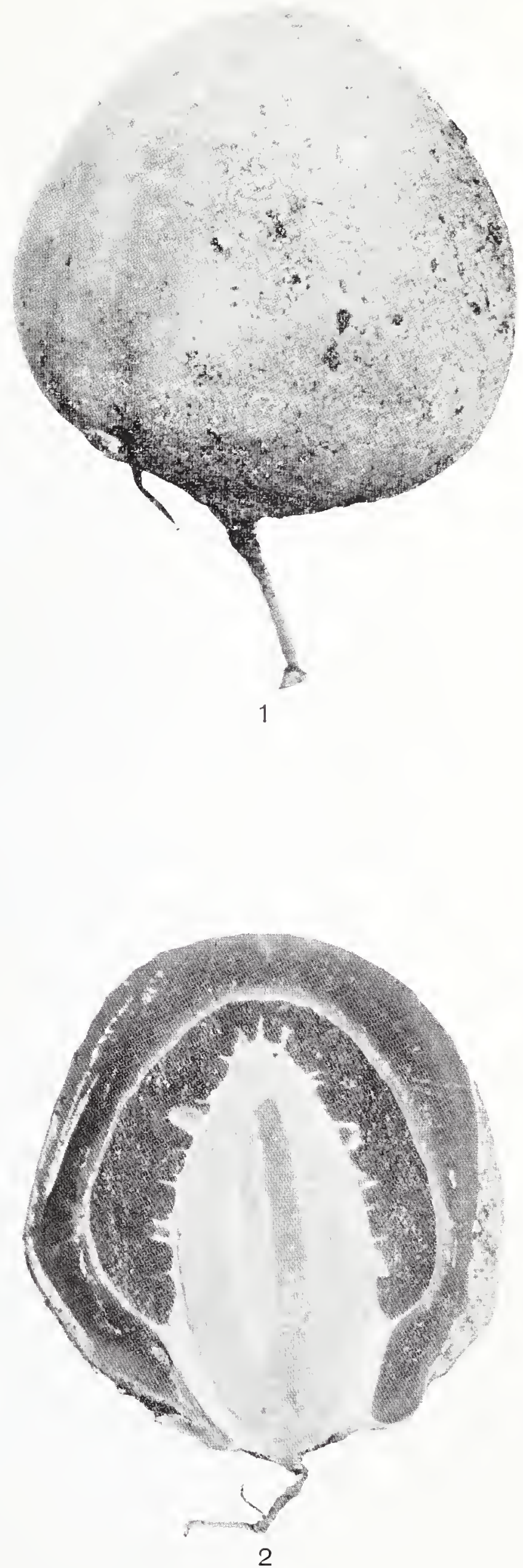

COMMON STINKHORN (PHALLUS IMIUDICUS) 


\section{DESCRIPTION OF PLATE XXV \\ COMMON STINKHORN (PHALLUS IMPUDICUS)}

IIIG. I. - An "egg" with the cord-like mycelium.

Fig. 2.-Section of an "egg," showing the three layers of the volva. The outside and the innermost are thin and skin-like, and surround the middle gelatinous layer. The pileus and stem may be seen in the centre of the section.

Fig. 3.-A mature plant. The pileus is joined to the stem only at its apex; its reticulated hollows hold the evil-smelling gluten in which the spores are immersed. (All after Lloyd; slightly less than natural size.) 
veloped. Common in woods, gardens, etc., especially under fir-trees, in sum and aut. Gregarious, springing from a thick white cord-like mycelium. Easily detected by the penetrating smell. In old fungus floras there is reference to a var. iosmos, said to differ in the serrate borders of the reticulations of the pileus, and in its smell of violets. It is supposed to have been described by a mycologist with defective olfactory organs. The unequal contraction of a phalloid "egg" when drying has been frequently observed in specimens exhibited in the Vivarium at the Haslemere Educational Museum. In the course of a month they shrunk to about a quarter of the original size, much resembling that depicted in Plate XXIV. 3 .

\section{MUTINUS}

\section{(An appellation of Priapus)}

M. caninus (canis, dog), "Dog Stinkhorn." Plate XXIV. 4,5 .

$P$. short, rugulose, red. Receptacle elongato-fusiform, white or rosy, cellular. The "egg" is about an inch high, the fully-developed plant from 3 to 5 in. Gregarious in woods and bushy places from June to Dec. Frequent. Never so strong smelling as P. impudicus; late in the year it is almost scentless.

\section{LYSURUS}

(Gr. luo, to loosen; ouva, a tail-from the free tail-like lobes of the mature pileus)

L. australiensis (from its native country, Australia).

$P . \frac{3}{4}$ in. diam., usually 5-lobed, lobes attenuated upwards, each with a longitudinal depression in the middle and transversely rugose, tawny. Receptacle cylindrical, hollow, cellular, whitish, 5-7 in. high. $V$. globose, lobed, white. A 
casual alien, introduced in refuse of Australian wheat. Recorded from Worcestershire by Mr. Carleton Rea, in Nov., I902.

\section{CLATHRUS}

(Clathnus, a lattice-from the latticed receptacle)

C. cancellatus (cancellatus, latticed-from the lattice-like receptacle), "Cage Fungus."

At maturity resembling a hollow latticed sphere $\left(4 \times 3 \frac{1}{2}\right.$ in. $)$, vermilion or like dingy red coral. Beautiful, but abominably fœetid. In sheltered woods and gardens in late aut., chiefly in the West of England. Rare. Probably occurs only as an alien introduced with plants.

\section{Sub-order HYMENOMYCETES}

Hymenium naked; basidia and spores exposed in the mature plant.

\section{KEY TO THE FAMILIES}

I. TREMELLINACE正 (Gelatinous Fungi).-Hymenium spread over a gelatinous surface. Sporophore gelatinous when moist, horny when dry.

II. CLAVARIACE无 (Club-bearing Fungi).-Hymenium spread over erect, simple, or branched clubs; in one genus (Sparassis) over large, leafy, coalescing branches. Sporophore everywhere covered by the hymenium.

III. THELEPHORACEæ (Leathery Fungi).-Hymenium on one side of the sporophore, which may be either resupinate, dimidiate, or provided with a central stem.

IV. HYDNACE正 (Teeth-bearing Fungi). - Hymenium spread over teeth, spines, or granular projections. Sporophore resupinate, dimidiate, or with a central stem.

V. POLYPORACE⿸ (Pore-bearing Fungi).-Hymenium lining the interior of small pores, tubes, or shallow depressions. Sporophore resupinate, dimidiate, or with a central stem.

VI. AGARICACE⿸ (Gill-bearing Fungi).-Hymenium spread over the surface of flat radiating plates (= gills or lamellæ). Sporophore resupinate, dimidiate, or with a central stem. 


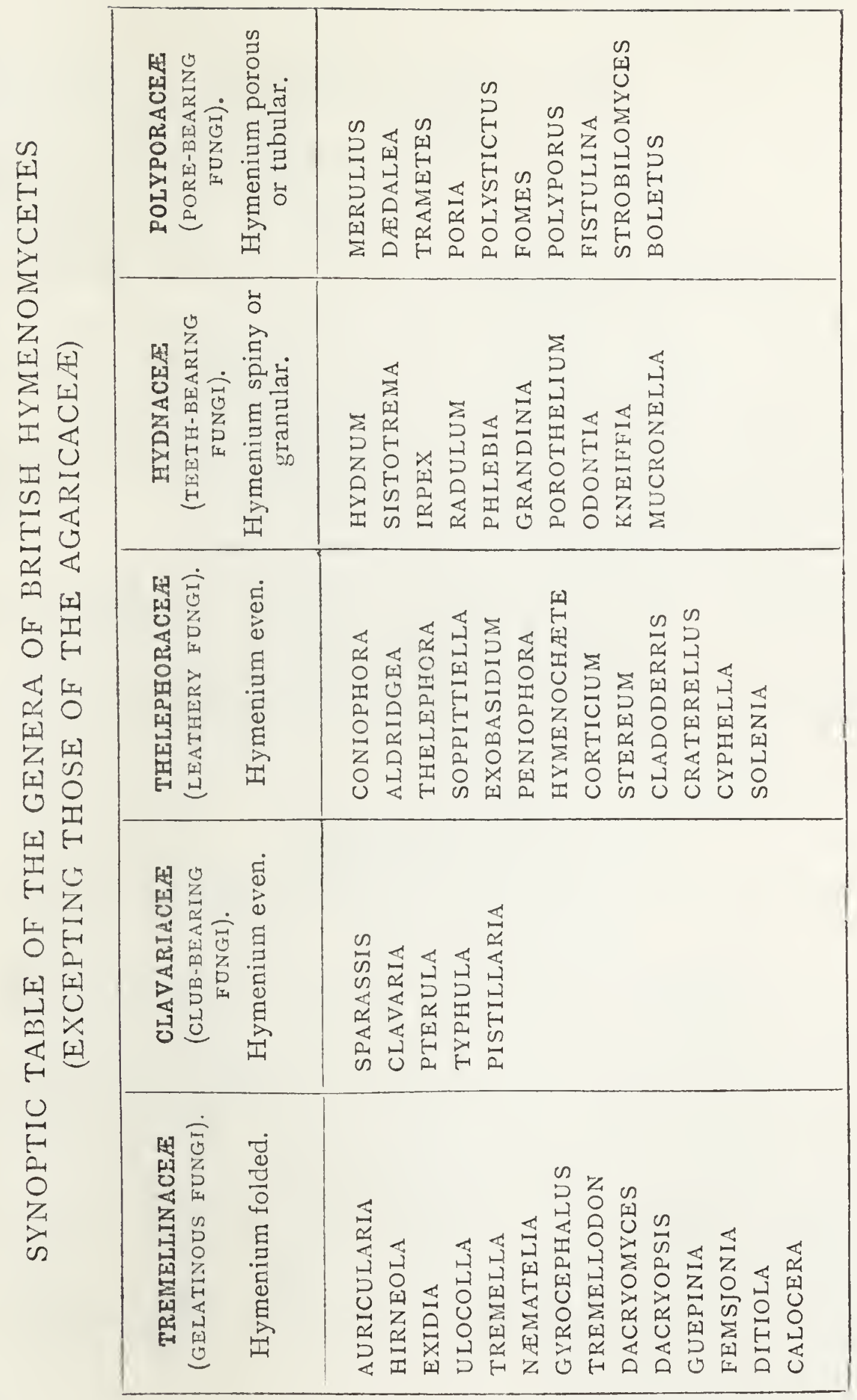




\title{
Family TREMELLINACE王
}

(Gelatinous Fungi)

\author{
KEY TO THE GENERA
}

Auricularia. Sporophore broadly attached to the matrix; the margin free and reflexed.

Hirneola. Cartilaginous, ear-shaped, attached by a point.

Exidia.

Ulocolla.

Tremella.

Næmatelia.

Gyrocephalus.

Sporophore cup-shaped, truncate, or irregularly lobed.

Sporophore large, pulvinate, and gyrose.

Sporophore brain-like or lobed.

Tremellodon. Hymenium with spines like a Hydnum.

Dacryomyces. Sporophore small, pulvinate, and gyrose.

Dacryopsis. Sporophore resembling a stalked Peziza.

Guepinia. Sporophore irregularly cup-shaped, with the hymenium on one surface only; substipitate.

Femsjonia. Irregularly cup-shaped, sessile, erumpent.

Ditiola. Stem distinct; hymenium on expanded apex.

\section{AURICULARIA}

(From the supposed resemblance of some species to an ear, auvicula)

A. mesenterica (from the supposed resemblance of the hymenium to the mesenteric membrane). XXVI. 6.

$P$. resupinate at first, then more or less reflexed, greyishbrown, zoned and velvety. $H$. brownish-violet, smooth or wrinkled, powdered with a beautiful bloom, inflated and gelatinous when moist, horny when dry. Frequent on old trunks and stumps of various trees, including yew and walnut, from April to Nov.

A. lobata, the remaining British species, differs chiefly in the lobed margin of the pileus. 

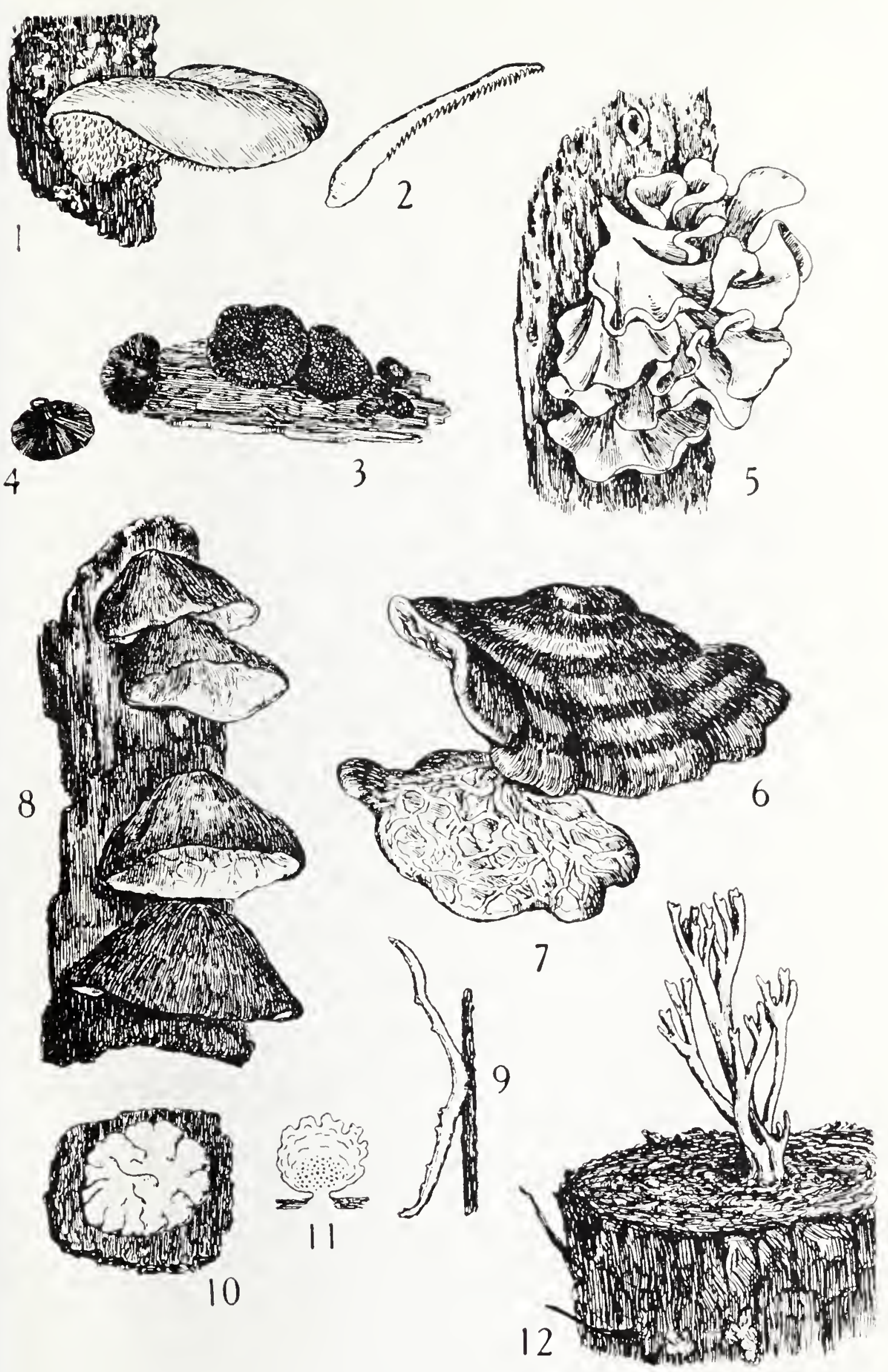


\section{DESCRIPTION OF PLATE XXVI}

\section{TYPES OF GELATINOUS FUNGI (TREMELLINACEÆ)}

FIG. I. - Tremellodon gelatinosum.

FIG. 2.-Ditto: section showing the stout fleshy teeth and stem-like base.

FIG. 3.-Exidia glandulosa, showing the papillate disc.

FIG. 4.-Ditto, showing the plicated lower surface.

FIG. 5.-Uloculla foliacea.

FIG. 6.-Auricularia mesenterica, showing the zoned reflexed pileus.

FIG. 7.-Ditto: the plicate hymenium.

FIG. 8.-Hirneola auricula-juda: pendulous sporophores.

Fig. 9.-Ditto: section showing the folds on the hymenium.

FIG. Io.-Niematelia encephala, showing the plicato-rugose sporophore.

FIG. II.-Ditto: section showing the firm central nucleus.

FIG. I2.-Calocera viscosa: sporophore growing from a decaying fir. stump. 


\section{HIRNEOLA}

(Hirmus, a jug-from the shape when young)

H. auricula-judæ, "Jew's-ear." Plate XXVI. 8.

Sph. cup-shaped or ear-shaped, dark brown, much like Peziza vesciculosa when young, thin and elastic, somewhat gelatinous at first, rigid when dry. "I-3 in. or more broad; upper substance corrugated, the plaits branching from the middle part, where they are strongest and somewhat convoluted, so as to give an idea of a human ear; when the plant grows on a perpendicular stump or tree it turns upwards" (Berkeley.) On living and dead elder and elm, frequent throughout the year.

\section{EXIDIA}

(Gr. exidio, to exude-from the exuding receptacle)

E. glandulosa (from the glandular hymenium), "Witches' Butter." Plate XXVI. 3.

Cup-shaped at first, resembling a Peziza, then flattened above and more or less folded below and somewhat hairy, varying in colour from grey to nearly black. About I in. diam. Common in aut. and win., on dead branches of oak and other trees. Easily recognised by the glandular hymenium and gelatinous substance. Bulgaria polymorpha differs in the tough rubbery substance, and is an Ascomycete.

E. recisa (vecido, to cut short-from its lopped appearance) is umber, brown, with plane hymenium; common on willow and poplar in aut. and early win. E. albida (albus, dead white-from the whitish bue) is frequent throughout aut. and win., on dead branches of various trees, forming whitish folds that become brownish or lavender at maturity. 


\section{ULOCOLLA}

(Gr. oulos, shaggy; kolla, glue-from its consistency and appearance)

U. foliacea (folium, a leaf-from the appearance). Plate XXVI. 5.

$S p h$. lobed and waved, segments thin, diaphanous, pinkishcinnamon or deep brown, sometimes violet. Forms soft gelatinous tufts, from I to 4 in. diam., on dying branches and stumps (especially beech), in ant. and win. Uncommon. Bulgaria polymorpha is said to be the conidial state of this species.

\section{TREMELLA}

\section{(From the jelly-like substance)}

T. mesenterica (from a supposed resemblance to the mesenteric membrane), "Yellow Jelly-sprout." Plate I. Io.

Forms somewhat tough, gelatinous, lobed tufts of a bright orange colour on dead branches, chiefly oak, gorse and broom, throughout the year, very abundant in win. At maturity pruinose with the white spores.

\section{N ÆMATELIA}

(Gr. naima, gelatine; eilo, to wrap round-from the gelatinous substance surrounding the hard nucleus)

N. encephala (Gr. en, within; kephale, the head-from the contained nucleus.) Plate XXVI. Io.

Sessile, pulvinate, more or less plicate, about I in: diam., flesh colour or salmon. Sometimes confluent and forming a patch 3-4 in. diam. Frequent in aut. and win. on branches, pine-rails, etc. Easily known by the solid kernel within. $N$. virescens, a greenish species, is common on gorse. 


\section{GYROCEPHALUS}

(Gr. guvos, round; kephale, the head-from the globular shape)

G. rufus (nufus, red). Sph. erect, 3 in. high, somewhat spoon-shaped or variously contorted and irregular, between horny and gelatinous in consistency, orange or dull scarlet. On the ground and on rotten trunks in pine woods. Rare.

\section{TREMELLODON}

(Gr. odous, a tooth, and from its resembling Tremella in substance)

T. gelatinosum (gelatina, jelly-from the gelatinous substance), "Jelly Hedgehog." Plate XXVI. I.

Sph. I-3 in., tremelloid, more or less fan-shaped, thick, with a lateral stem-like base, bluish-grey, sprinkled with minute white granules. $H$. watery-grey, covered with stout, acute, gelatinous spines. Gregarious or solitary, sometimes tufted, forming a contorted mass 6 in. diam. or more. Said to be rare, but is not infrequent in shady pine woods on the Neocomian sands in the South of England.

\section{DACRYOMYCES}

(Gr. $d a k n u$, a tear; mukes, a fungus-from the tear-like habit)

D. deliquescens (deliquesco, to dissolve-from its appearance). Forms minute, gelatinous, wavy, roundish masses on pine wood, throughout the year, but most abundantly in win. Frequently appearing as long yellow lines out of cracks in the wood. "It often resembles very much a cæspitose, waved yellow Peziza, growing in clusters, sometimes an inch or more in length" (Cooke). 


\section{DACRYOPSIS}

(From its relation to Dacryomyces)

D. nuda (midus, naked-from the absence of a veil). Forms a reddish-orange hemispherical head ( $\frac{1}{4}$ in. diam.), surmounting a stout yellowish-white, minutely tomentose stem. Gregarious on fir-stumps, etc., in ant.

\section{GUEPINIA}

\section{(After Jean Pierre Guepin)}

G. peziza (shaped like a Peziza).

Forms a minute yellow or orange irregular cup, not exceeding $\frac{2}{3}$ in. diam., obliquely attached by a slender stem ( $\frac{1}{4}$ in. long) to dead wood in aut.

\section{FEMSJONIA}

(From Femsjo, the name of a place)

F. luteo-alba (luteus, yellow; albus, white-from the yellow disc and white exterior).

Sph. shaped like a Peziza at first, about $\frac{3}{4}$ in. diam.; plane at maturity, the disc bright yellow, with a narrow whitish margin, under surface whitish. Rooting, bursting through the bark of fallen birch and oak branches in aut. Uncommon.

\section{DITIOLA}

(Gr. dittos, double; ioulos, down-from the down-like veil)

D. ulicis (the gorse, Ulex europaus-its habitat). Sph. globose, then flattened and wrinkled, lemon-yellow, $\frac{1}{2}$ in. high. Common in win. on dead gorse stems. 


\section{DESCRIPTION OF PLATE XXVII}

TYPES OF FAIRY-CLUB FUNGI (CLAVARIACEÆ)

FIG. I.-Pistillaria quisquillaris. (Natural size.)

FIG. 2.-Pistillaria temiipes. (Natural size.)

FIG. 3. - Typhula erythropus. (Natural size.)

Fig. 4.-Ptevila subulata.

FIG. 5.-Clavaria juncea.

Fig. 6.--Clavaria pistillaris. (One-quarter natural size.)

FIG. 7.-Clavaria fusiformis. (One-quarier natural size.)

FIG. 8.-Clavaria fistulosa.

FIG. 9.-Clavaria stricta. 

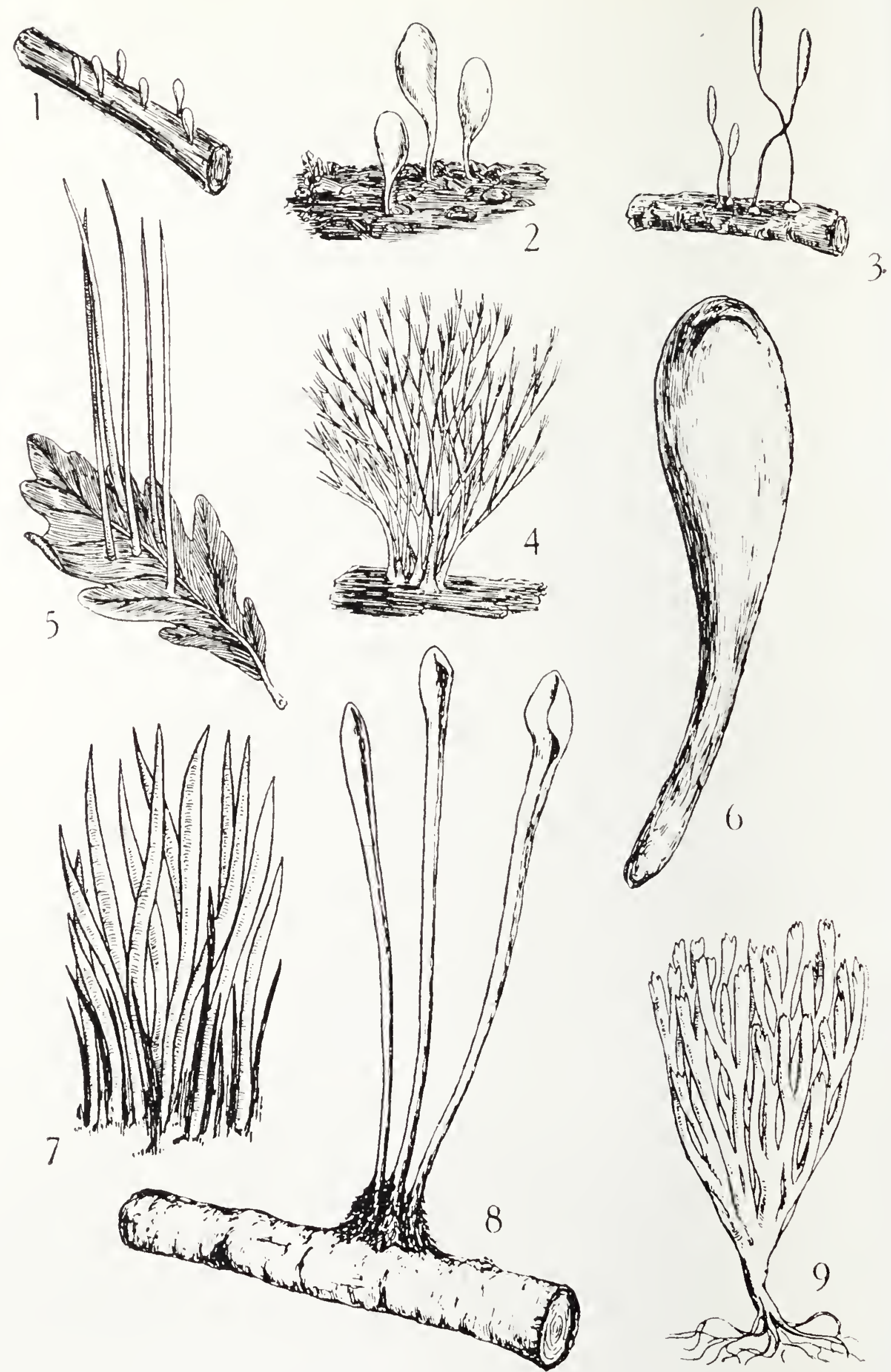


\section{CALOCERA}

(Gr. kalos, beautiful; kevas, a horn-from its shape and colour)

C. viscosa (from its viscidity). Plate XXVI. I2.

$S p h$. branched, straight, repeatedly forking, orange-yellow, I-3 in. high, exactly resembling a Clavaria. Very common on rotten fir-stumps throughout the year, especially late ant. The long pale root penetrates deep into the wood. Easily known by its stickiness, beautiful orange colour, and habitat.

\section{CLAVARIACE $ઋ$ \\ (Club-bearing Fungi)}

KEY TO THE GENERA

Sparassis. Sporophore consisting of many compressed crisped branches, forming a large tuft resembling the heart of a cauliflower.

Clavaria. Sporophore a fleshy, sinsple, or more or less branched club, without a distinct stem.

Pterula. Sporophore consisting of small, very slender hair-like branches, forming a brush-like tuft.

Typhula. Sporophore a simple club, with a distinct stem, usually springing from a sclerotium.

Pistillaria. Sporophore a minute simple club, with a distinct stem, usually not springing from a sclerotium; rigid when dry.

\section{SPARASSIS}

(Gr. sparasso, to tear to pieces-from the appearance of the sporophore)

S. crispa (crispa, a curl-from its crisped or curled appearance). Plate XXVIII.

Forms large globose tufts, resembling the heart of a cauliflower (or "like a sponge"), at the base of Scotch pines in aut. in shady woods. Whitish or pale yellow, branches laciniate, crisped, and brittle. Stem-like base, usually deeply rooted. It is not uncommon in pine woods on the Green. 
sand in the South of England, often attaining great size. Worthington Smith records an enormous Kentish specimen, $3 \frac{1}{2} \mathrm{ft}$. in circumference, Io in. high, with a solid base of mycelium 6 in. below the ground. One brought to the Haslemere Museum in Oct., I906, measured $3 \mathrm{ft} .8$ in. in circumference, and weighed nearly 6 pounds. It had been cut off level, with the ground.

S. laminosa (lamina, a thin leaf-from the leaf-like plates). Plate XXVIII.

Closely allied to S. crispa, and occurring in similar situations. The branches are more lax and leaf-like, not so compact and crisped. First recorded for Britain during the visit of the British Mycological Society to Woolmer Forest, Sept. 26, I905. The plate depicts the specimen found on that occasion.

\section{CLAVARIA}

(Clava, a club-from the club-like shape of typical species) Section I.-Branched, the Branches attenuated UPWARDS

\section{(a) Spove Mass white or dingy white}

C. fastigiata (fastigium, a slope-from the arrangement of the branches). Plate XXIX. 2.

Rather tough, usually tufted, very much branched, the branches sometimes decreasing in height outwardly, giving the plant a sloping appearance. Amongst grass in pastures, aut. and win. Slightly fragrant. Easily recognised by the clear egg-yellow colour. The tips are sometimes brown.

C. muscoides (muscus, moss; Gr. eidos, appearance).

Differs from $C$. fastigiata in the more slender stems (hairy at the base) not being so branched, nor so repeatedly. It occurs in similar situations. Solitary. Common in aut.

C. cinerea (cinis, ashes-from its ashy colour). Plate XXIX. 7.

Branches numerous and irregular. Sometimes with a few 


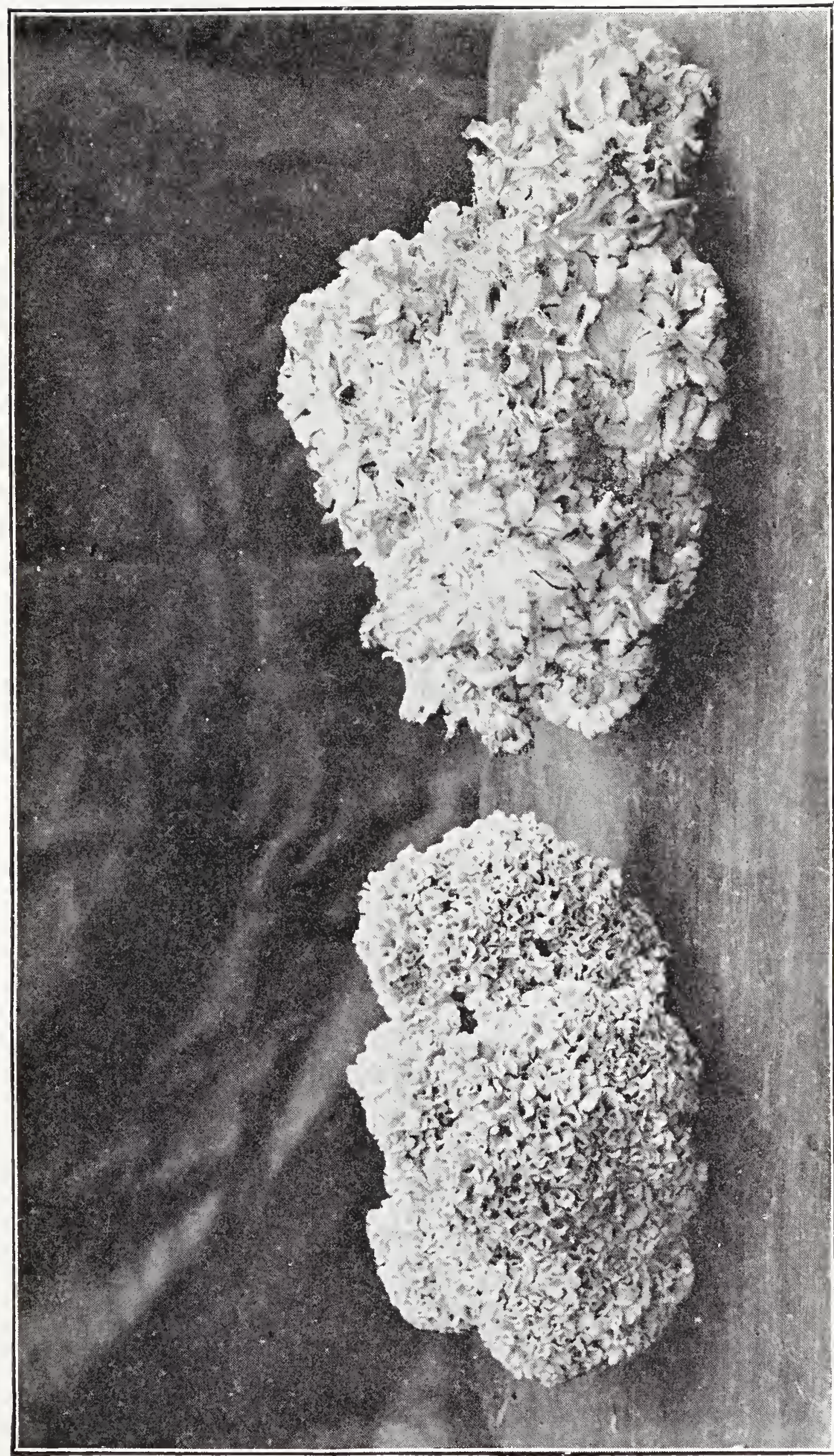




\section{DESCRIPTION OF PLATE XXVIII}

Sparassis crispa and Sparassis laminosa (about one-quarter natura! size). From a photograph by Mr. Roger Hutchinson, Haslemere. The block for this illustration was kindly lent by the British Mycological Society. 
short branchlets, or compressed with many pointed branchlets at the tip. Stem short. Usually gregarious or in crowded tufts, measuring 5 by 4 in. Frequent in shady woods in aut.

C. rugosa (nuga, a wrinkle), "Wrinkled Fairy-club." Plate XXIX. 7 .

Solitary or gregarious, 3-5 in. high, about $\frac{1}{4}$ in. thick. Whitish. Sometimes a simple club, sometimes branched, but always blunt at the tip. Very common in hedges and woods, especially under chestnut and fir, in aut. Easily recognised by the distinct longitudinal wrinkles.

\section{(b) Spore Mass ochraceous or cimnamon}

C. abietina (abies, a fir), "Little Besom." Plate XXVIII. 4. From I to 3 in. high, in fir woods, chiefly spruce, in ant. Much branched from a stout base. There is great variability in the thickness and in the division of the branches. Often resembling a besom in miniature. Deep ochre, stem whitish and downy. Known at once by turning greenish when bruised.

C. stricta (stringo, to draw tight-from the tense habit). Plate XXVII. 9.

Densely branched, erect, the branches repeatedly forking, tips acute, about 4 in. high. Stem short, rather slender, but distinct. Pale dull yellow, becoming brown when bruised. On trunks in woods in aut., often springing from a cord-like mycelium. Uncommon.

Section II.-Clubs almost simple, usually tufted AT THE BASE

C. fusiformis (fusus, a spindle; forma, shape-spindleshaped), "Golden Spindle." Plate XXVII. 7.

Branches elongated, primrose-yellow, rarely unequally branched, about 3 in. high. Top contracted into a brownish $6-2$ 
spine-like point. Common in aut. in woods and pastures. Many individuals appear together, and form a little tuft.

C. inæqualis (incqualis, unequal). Plate XXIX. 5 .

Very common in woods, and in pastures bordering them. Fragile, yellow, I-3 in. high. Scattered or in loose tufts. Very variable in size and form, simple or forked and often compressed.

C. argillacea (argilla, clay). Plate XXIX. I.

Club-shaped or cylindrical, simple or loosely tufted, pale clay colour or greenish-white; stem yellowish, very distinct. Frequent amongst moss and grass on heathy moors in aut.

C. vermicularis (vermis, a worm-from a fancied worm-like shape). Plate XXIX. 6.

Densely or loosely tufted, white, very brittle, tips more or less pointed, sometimes forked. "Looks like a little bundle of candles." Very common amongst grass in aut. (C. fragilis is this species.)

C. Iuteo-alba (hutens, yellow; albus, white), "White-tipped Fairy Club." Plate XXIX. 3.

Long confused with $C$. incequalis, but easily known by the white tip. First noted and described by Mr. Carleton Rea in I903. Frequent amongst grass and in hedges, especially under holly.

\section{Section III.-Clubs almost simple, distinct at the}

\section{BASE}

C. pistillaris (pistillum, a club), "Dryad's Club." Plate XXVII. 6.

In woods, particularly beech, in ant. Variable in size, 4-I 2 in. high, usually club-shaped, always simple and smooth. Whitish at first, dingy-brown at maturity. Uncommon.

C. fistulosa (fistula, a pipe). Plate XXVII. 8.

A simple club, 4-7 in. high, hollow, thickened and compressed above, yellowish, then rufescent. Sometimes two or three spring together from a tuberous hairy base (the 

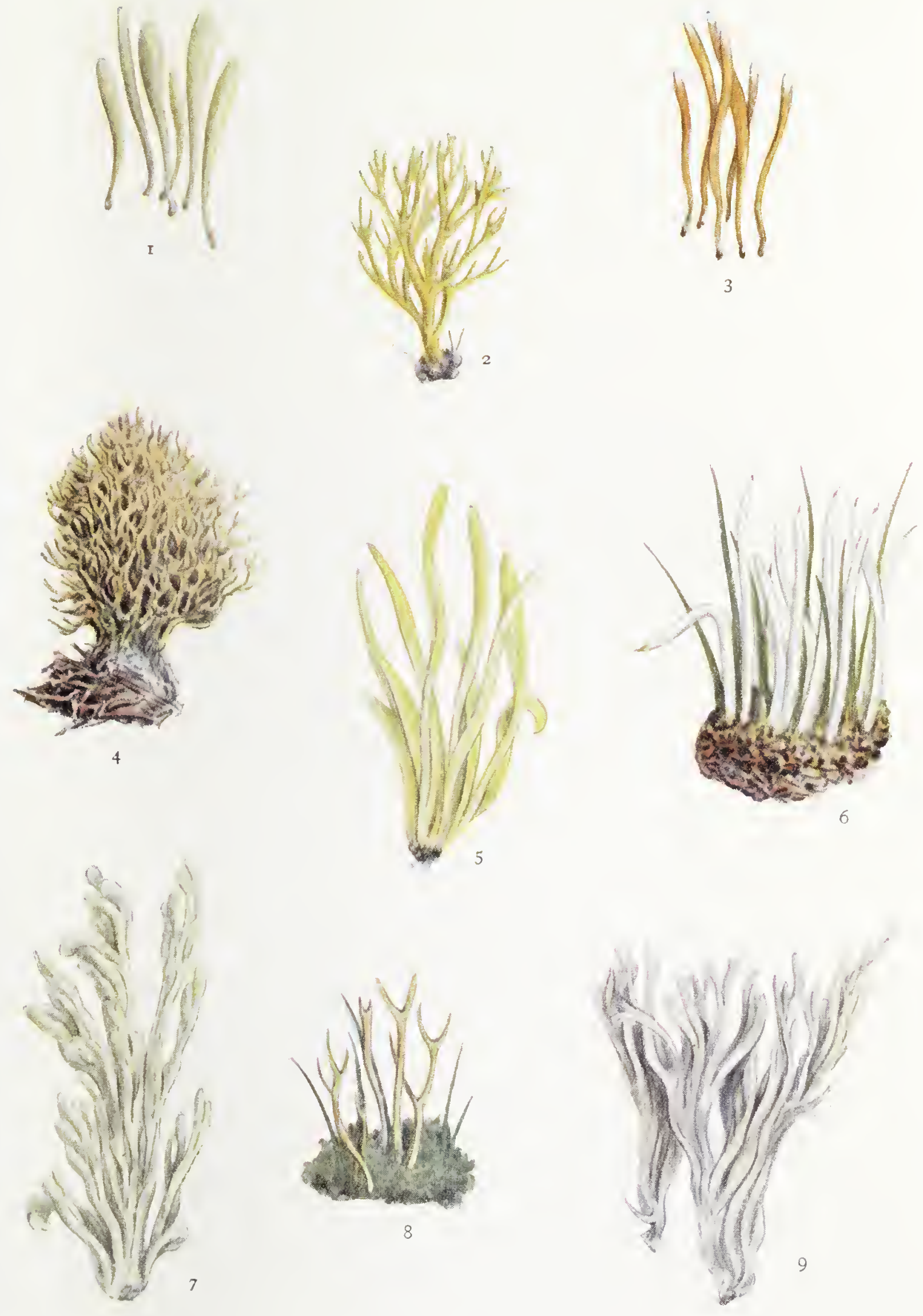

SOME FAIRY CLUBS (CLAVARIAE) 


\section{DESCRIPTION OF PLATE XXIX}

\section{SOME WEIL-KNOWN FAIRY-CLUBS (CLAVARIE)}

$\begin{array}{ll}\text { FIG. I.- Clivaria argillacea: } & \text { FIG. 5.-C. incequalis. } \\ \text { young plants. } & \text { FIG. 6.-C. vermicuiaris. } \\ \text { FIG. 2.-C. fastigiata. } & \text { FIG. 7.-C. cinerea. } \\ \text { FIG. 3-C. luteo-alba. } & \text { FIG. 3.-C. muscoides. } \\ \text { FIg. 4.-C. abictina. } & \text { FIG. 9.-C. rugosa. }\end{array}$


condition known under the name of C. tuberosa), usually scattered. On decaying birch twigs in late ant. Rare.

C. juncea (juncea, a rush). Plate XXVII. 5 .

Very slender, not exceeding two lines in thickness, hollow, sometimes hair-like, and must then be carefully distinguished from Typhula. Pale dingy yellow, then reddish. Gregarious on decaying leaves and twigs in woods in aut. Uncommon.

\section{PTERULA}

(Gr. pteron, a wing--from a fancied resemblance to a little wing)

P. subulata (subula, an awl-from the awl-shaped branches). Plate XXVII. 4.

Forms densely crowded, sparingly divided, greyish or yellowish smooth branches ( 2 in. high), of thread-like thinness. The branchlets are much divided at the apex. In aut. and win. on branches, leaves, fern-stems, etc.

\section{TYPHULA}

(From the fancied resemblance of some species to the Typha or Reed Mace)

T. erythropus (Gr. enthros, red; pous, a foot). Plate XXVII. 3 .

The club is white, stem dark red or blackish. Slender, not exceeding I in. in height. Common in aut. on dead leaves, sticks, and herbaceous stems. Often springing from a wrinkled black sclerotium.

\section{PISTILLARIA \\ (Pistillum, a pestle-from the form)}

P. tenuipes (temis, thin; pes, a foot). Plate XXVII. 2.

Pale drab, about I in. high, and up to $\frac{1}{2}$ in. diam. in the head. Solitary or gregarious on bare heathy soil and charcoal heaps in Oct. and Nov 
P. quisquillaris (quisquilia, sweepings, rubbish-from its habitat). Plate XXVII. I.

Forms minute whitish clubs, $\frac{1}{8}$ in. high, on dead leaves and fern-stem (especially bracken) in aut. Gregarious. Common.

\section{Family THELEPHORACE屟}

\section{(Leathery Fungi)}

\section{KEY TO THE GENERA}

Coniophora. Resupinate, dry. Hymenium pulverulent.

Aldridgea. Resupinate; soft and gelatinous.

Thelephora. Resupinate to erect, dry. Hymenium rugulose.

Soppittiella. Encrusting or effused. Subgelatinous. Hymenium even.

Exobasidium. Parasitic on living leaves and stems.

Peniophora. Hymenium with colourless cystidia. Rough at the tip with particles of lime; hence appearing minutely velvety under a pocket lens.

Hymenochæte. Hymenium with brown smooth cystidia. Minutely velvety when viewed with a pocket lens.

Corticium. Resupinate. Hymenium smooth and even, cracking when dry.

Stereum. Effuso-reflexed. Pileus silky or strigose. Hymenium even, glabrous.

Cladoderris. Horizontal; attached by a small point behind. Hymenium radiato-rugulose.

Craterellus. Large, erect, funnel-shaped. Hymenium glabrous.

Cyphella. Minute, cup-shaped, usually single, mouth open.

Solenia. Minute, cylindrical, gregarious or crowded. Tubular, with the mouth contracted.

\section{CONIOPHORA}

(Gr. konis, dust; phoveo, to carry-from the hymenium being powdered with the spores)

C. olivacea (from its colour). Plate XXX. 5 .

Forms dull olive patches, up to 5 in. across on pine wood 

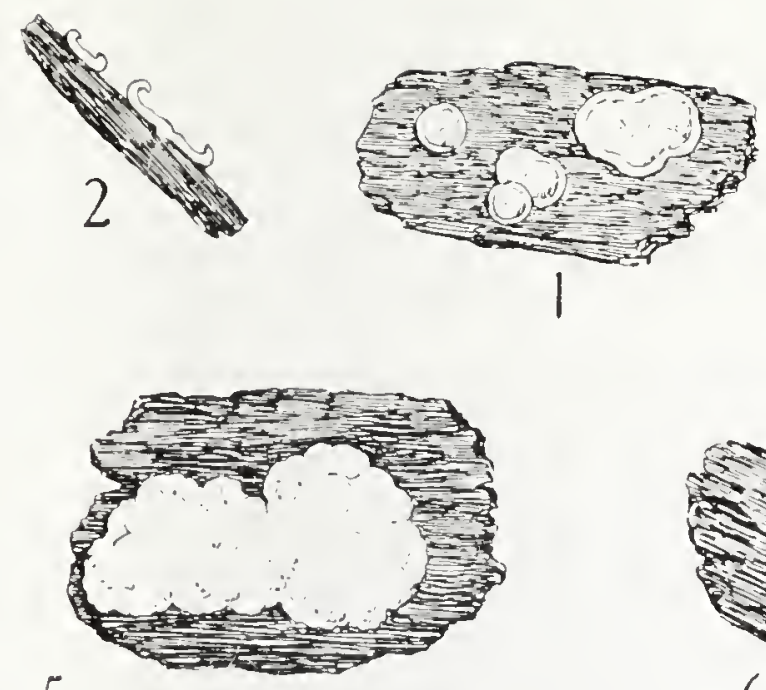

5
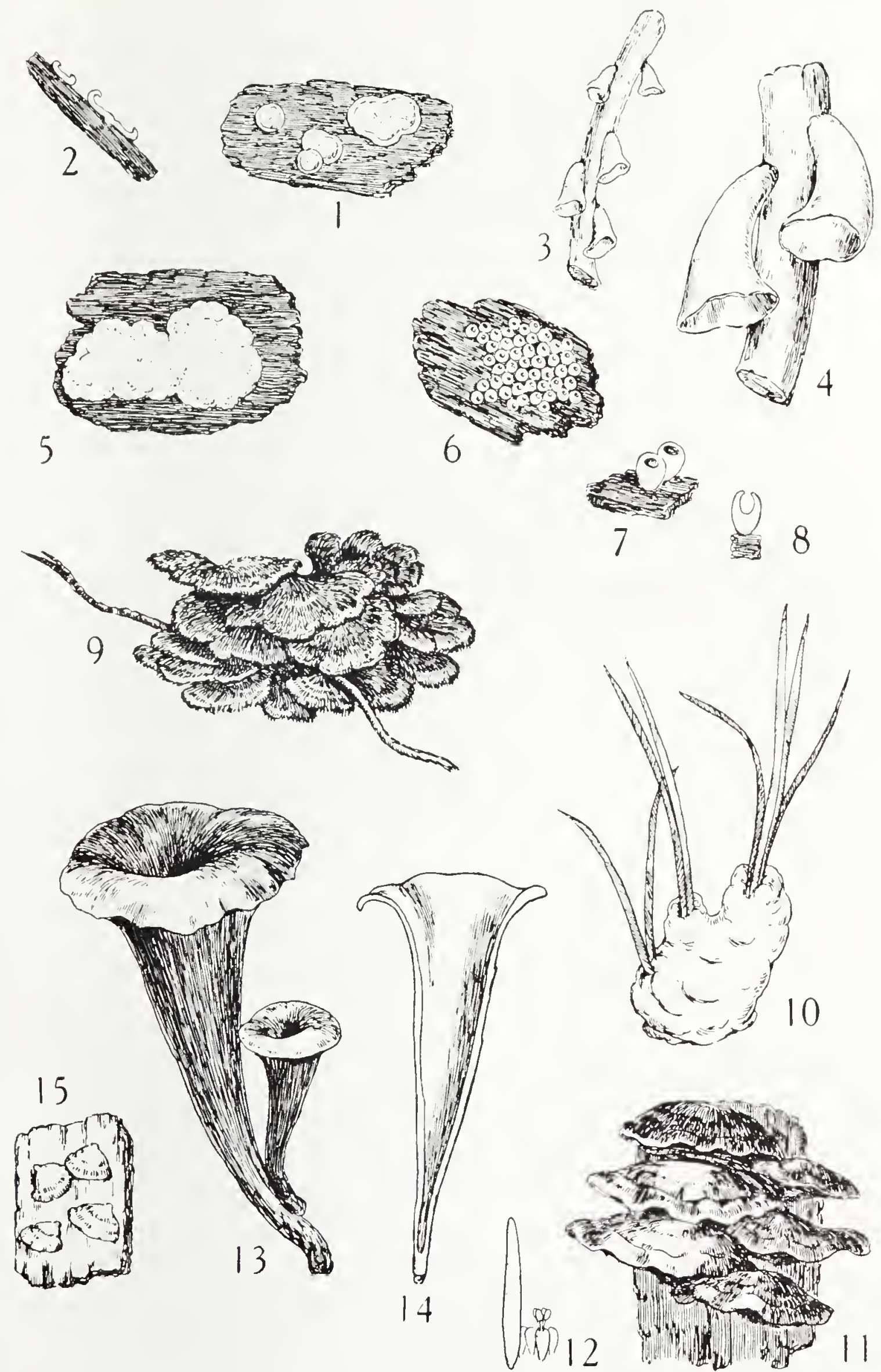

6
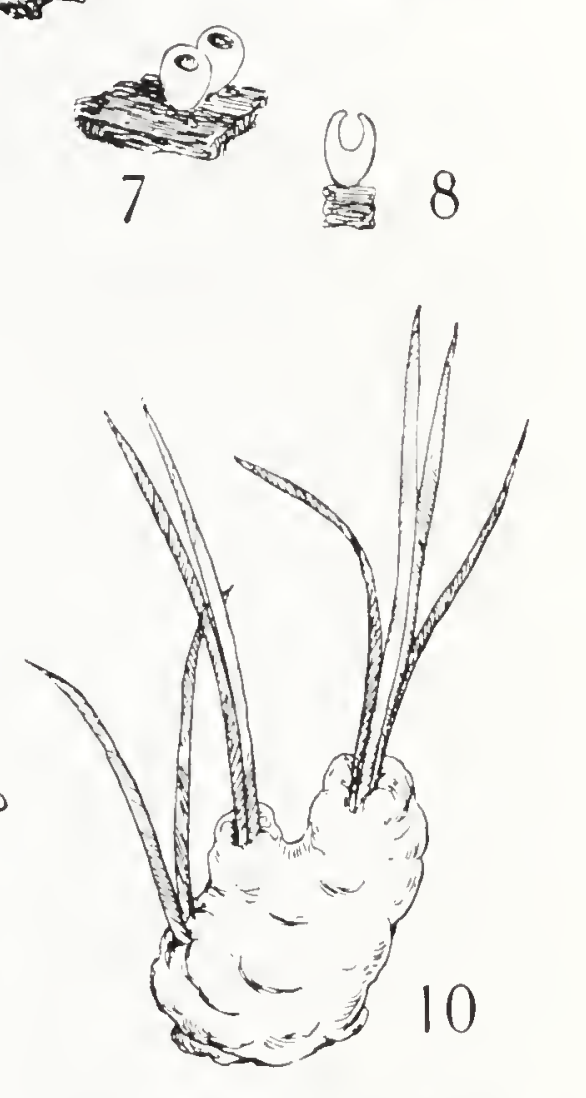


\section{DESCRIPTION OF PLATE XXX}

\section{TYFES OF LEATHERY FUNGI (THELEPHORACE巴)}

FIG. I.-Corticium salicinum.

FIG. $z_{0}-$ Ditto, showing the Peziza-like form.

FIG. 2.-Cythella capuld. (Natural size.)

FIG. 4.-Ditto, magnifis.]

FIG. 5.-Coniophora olivacca.

Fig. 6.- Solenia anomela. (About twice natural size.)

FIG. 7 -Ditto, magnified.

FIG. S. - Section (magnified) showing the incurved margin.

Iirs. 9.- Thelephora laciniata.

FIG. IO.-Soppitticlliv cristata, incrusting grass.

FIG. II.-Hymenochate mubiginos. : a group of imbricated pilei.

FIG. I2.-From the hymenium of Hymonochate rubiginosa, showing a cystidium projecting far above the basidia and spores. (Highly mag. nified.)

FIG. I3.-Craterellus cornucopioid s.

FIG. I . - Ditto: section showing the desply infundibuliform pileus.

Fig. I5. -Cladoderiris minima, (Natural size.) 
in Nov. It sparkles when fresh with crystals of oxalate of lime. Uncommon.

C. sulphurea (from its colour).

Forms brownish-yellow patches, with a bright sulphurcoloured margin on bark, leaves, etc. Often fibrillose, the radiating strands cord.like. Frequent in early win.

\section{ALDRIDGEA}

(After Miss Emily Aldridge, a Sussex mycologist)

A. glutinosa (from its gelatinous consistency), the only British species, forms broadly effused pallid or purplishbrown patches on sawdust, extending for several inches.

\section{THELEPHORA}

(Gr. thele, a teat; phero, to bear-from the sometimes papillose hymenium)

T. laciniata (lacinia, a flap-from the fringed margin of the pileus). Plate XXX. 9.

Sph. brown, fibrous, with a shaggy margin, roundish, the lobes overlapping, thin and soft. In fir woods, terrestrial and running up twigs, heather, etc. Common in woods and on beathy Greensand moors. Perennial. Aut. and early win.

T. anthocephala (Gr. anthos, a flower; kephale, the head) is rusty brown, with whitish fringed tips. Frequent on the ground in woods, with the habit of a Clavaria.

\section{SOPPITTIELLA}

(After T. H. Soppitt, a Yorkshire mycologist)

S. cristata (crista, a crest). Plate XXX. Io.

Forms thin, pallid, paint-like patches ( 5 in. diam.) on the ground, or encrusting leaves, moss, grass, etc, in aut. Sometimes forming cristate branches ( $\mathrm{I}$ in. high), with beautifully fringed apices. Never silky. 
S. sebacea (seba, tallow-from its tallow-like appearance).

Forms the familiar crust-like patches on rotten stumps, particularly fir. Often encrusting fir-needles, twigs, grass, etc. Tinged brown or cinnamon when dry.

\section{EXOBASIDIUM}

(Ex, out of-from the habit, growing spores on basidia without any true sporophore)

E. vaccinii (from its host, Vaccinium). Plate XIV. I.

Forms globular swellings on living leaves of the Whortleberry (Vaccinium myrtillus), rarely on the leaf-stalks and stems. The flesh-coloured hymenium protrudes from the under surface of the leaf; the opposite upper surface is red or purple. An allied species, E. vhododendvi, causes large galls, varying in size from a pea to a marble, on leaves and twigs of rhododendrons, especially Rhododendron ferrngineum. Uncommon.

\section{PENIOPHORA}

(Gr. penion, a shuttle; phero, to bear-from the shuttle-like setæ (modified cystidia) borne on the hymenium)

P. incarnata (incarnatus, flesh-coloured). Plate I. 3.

Forms broadly effused reddish or orange patches on wood and bark; very common on dead gorse and broom. The colour is maintained in a dried specimen, which feature distinguishes it from $P$. rosea. In both species the margin is whitish and fringed. Common, except in sum.

\section{HYMENOCHÆTE}

(Gr. humen, a membrane; chaite, a bristle-from the bristly hymenium)

H. rubiginosa (vubigo, rust-from the colour of the hymenium). Plate XXX. II.

Ferruginous brown, often with a purple tinge, foxy rust colour within. Variable, quite resupinate, slightly reflexed, 
or broadly reflexed and densely imbricated. Margin brighter. Sometimes little pilei appear to spring from the adnate portion between the reflexed edges. Perennial, on gateposts, etc. Throughout the year. Common.

\section{CORTICIUM}

(Cortex, bark-from the usual habitat)

C. salicinum (salix, willow-from the usual habitat). Plate XXX. I.

$S p h . \frac{1}{4}$-I in., leathery at first, rigid when dry, fixed by the centre with a raised margin all round. $H$. blood-red, whitish and somewhat hairy below. Gregarious on willow (rarely poplar) in aut. Resembles a Peziza.

C. calceum (calx, lime-from the chalk-white colour), common in sum. and aut. on dead wood and branches, margin determinate. C. lacteum (lac, milk-from the milkwhite colour) is a winter species, with radiating fringed margin, frequent on dead trunks. C. sambuci (from the habitat; elder, sambucus) forms the familiar pure white patches effused on dead elder. C. cavuleum (caruleum, azure-blue), a winter species, is easily recognised by its beautiful dark satiny-blue colour.

\section{STEREUM}

(Gr. steveos, hard-from its hard substance)

S. hirsutum (hirsutus, hairy-from the strigose hymenium). Plate I. 9.

One of the commonest, most conspicuous and most variable of species, usually appearing as bright yellow patches on trunk and branches. Quite resupinate when growing beneath a log, resupinate with a free margin when growing from a vertical matrix, and often with a central stem-like base when growing on the top of a prostrate log. $P$. coarsely strigose, dingy yellow, more or less zoned, 
corky. Sometimes many imbricated pilei are present. Throughout the year, especially on oak, and at its best in win.

S. purpureum (purpuveus, purple) is the pretty pale purple species, with whitish pileus, so commonly seen on dead fir.

S. rugosum (nuga, a wrinkle-from the usually wrinkled hymenium) forms large pale greyish-yellow patches (which become slightly red when bruised) on dead hazel-stumps, etc.

\section{CLADODERRIS}

(Gr. klados, a young branch; dervis, a leathern coat-from the branched and leathery structure)

C. minima. Plate XXX. I5.

A minute gregarious species, resembling dwarfed specimens of Steveum hirsutum, but distinguished by the radiating ridges of the hymenium. White at first, yellowish-tan when dry. Resupinate on birch bark in Dec.

\section{CRATERELLUS}

(From the resemblance of the sporophore to a small crater or bowl)

C. cornucopioides (cormu, horn; copia, plenty-shaped like a cornucopia), "Horn of Plenty." Plate XXX. I3.

Trumpet-shaped, smoky-black within, grey without, and indistinctly wrinkled. Gregarious, and often tufted. Size variable, 2-3 in. high. In woods, chiefly on clay soil, beneath hazel undergrowth. Said not to be attacked by insects. The "Trombetta di morte" of the Italians. At one time sold in Covent Garden Market.

\section{CYPHELLA}

(Gr. kuphos, a small goblet-from the usual shape)

C. capula (from its resemblance to a small bowl, capula). Plate XXX. 3. 


\section{DESCRIPTION OF PLATE XXXI}

TYPES OF TEETH-BEARING FUNGI (HYDNACEA)

FIG. I.-Hydnum repandum.

FIG. 2.--Ditto, section.

FIG. 3.-Hydnum auriscalpium : group of plants of various ages.

FIG. 4.-Ditto: section showing the lateral stem.

FIG. 5.-Sistotrema confluens.

FIG. 6. -Ditto, section.

FIG. 7.-Ditto: teeth, slightly magnified.

Fig. 8. -Odontia fimbriata: a small patch. (One-quarter actual size.)

FIG. 9. -Ditto: section (enlarged) showing the teeth.

Fig. Io.--Hydnum ochraceum. (Natural size.)

FIG. II. - Hydnum imbricatum.

FIG. 12.-Ditto, section. 

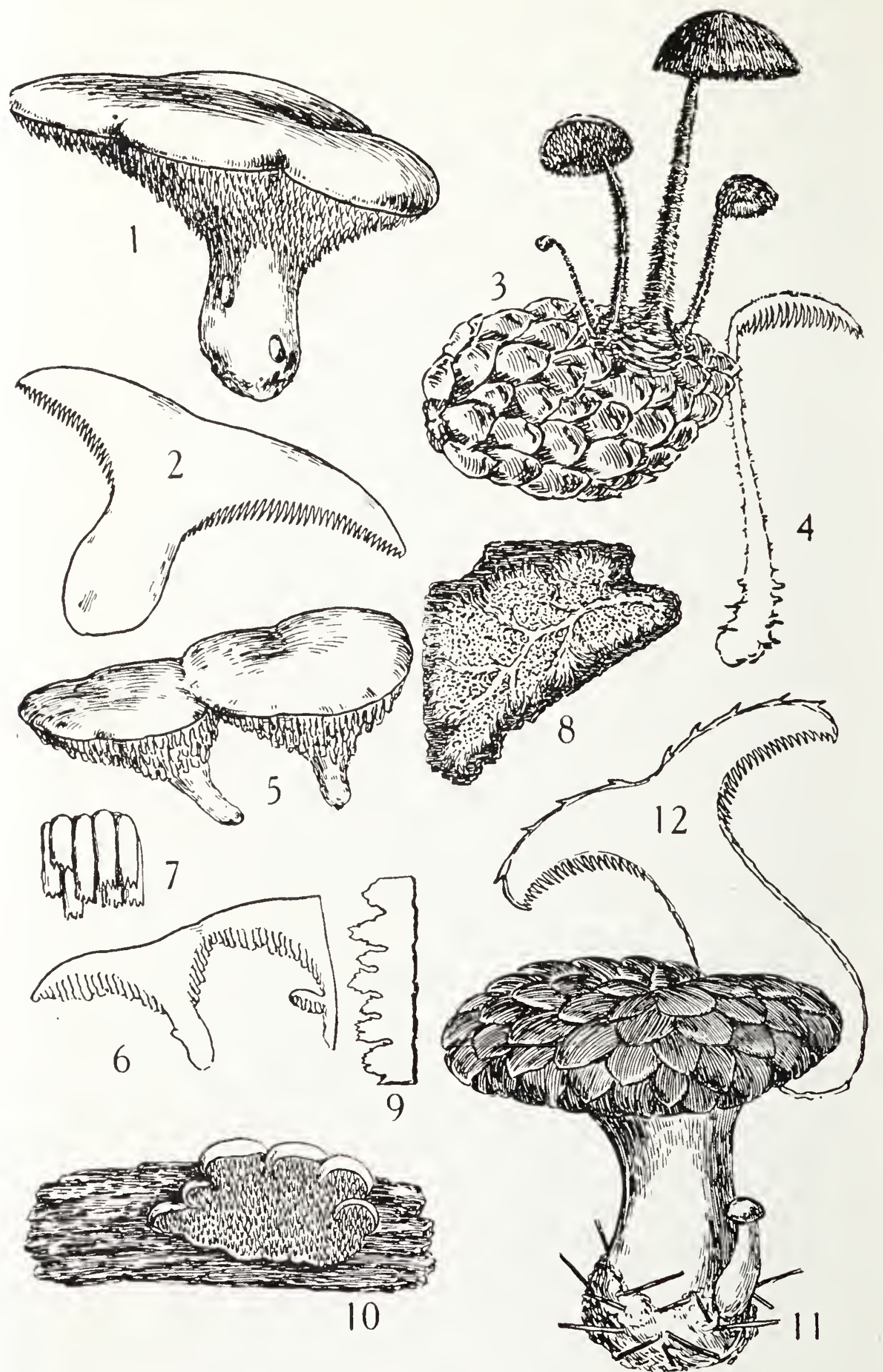
Cup-shaped, $\frac{1}{4}$ in. high, membranaceous, erect or drooping, smooth, margin sinuate, irregular. $H$. even whitish or yellowish, rarely brownish. Gregarious on dead herbaceous stems in damp situations in aut. Frequent.

\section{SOLENIA}

(Gr. solen, a pipe-from the short pipe-like shape)

S. anomala (from its anomalous character). Plate XXX. 6.

Forms effused patches on rotten wood and bark, $\frac{1}{2}$ in. or more across. It might easily be mistaken for a Poria, the tubes being very minute, and more or less incurved at the mouth. Externally pilose, varying in colour from dingy ochreous to ferruginous.

\section{HYDNACE无 \\ (Teeth-bearing Fungi) \\ KEY TO THE GENERA}

Hydnum. Sporophore fleshy, with a central stem, or resupinate. Hymenium covered with teeth, which are acute and distinct at the base.

Sistotrema. Sporophore fleshy, with a central stem. Hymenium covered with flattened and irregular teeth.

Irpex. Resupinate. Hymenium covered with teeth that are rather acute, and spring from folds or ridges.

Radulum. Resupinate. Hymenium covered with coarse, deformed, subcylindrical and obtuse tubercles.

Phlebia. Resupinate. Hymenium covered with folds or wrinkles.

Grandinia. Resupinate. Hymenium covered with minute, persistent, hemispherical granules.

Porothelium. Resupinate. Hymenium covered with wart-like granules, which are excavated at the apices.

Odontia. Resupinate. Hymenium covered with granules that are divided at the apices in a pencil-shaped manner.

Kneiffia. Resupinate. Hymenium covered with very minute, barren, acute spinules.

Mucronella. Resupinate. Hymenium covered with long, slender, acute spines, destitute of any sporophore or subiculum. 


\section{HYDNUM}

(From the Gr. hydnon, a truffle-curiously used by Linnæus for this genus)

H. imbricatum (imbrex, a tile-from the scaly pileus), "Scaly Urchin." Plate XXXI. I I.

P. 2-5 in., mouse-brown or reddish, with imbricated scales. $F$. reddish-brown above, remainder white. Spines long, crowded, greyish, decurrent on the thick whitish central stem. Singly or in twos and threes in pine woods in aut. Uncommon, Esculent.

H. repandum (repandus, repand), "Urchin of the Woods." Plate XXXI. I.

Altogether pale yellow or reddish, or stem and spines of a lighter colour. P. 2-6 in., spines short, crowded, brittle. S. 2-4 in., usually central, thick, fleshy, sometimes covered with white down. Subgregarious in woods in aut., especially under beeches. Common. Esculent.

H. auriscalpium (auriscalpinm, an ear-pick-from the shape). Plate XXXI. 3.

$P . \frac{1}{2}$-I in., dark brown, hairy, sub-rotund. Spines crowded, dark. S. lateral, 2-3 in., dark, base shaggy, often buried to some depth in fir leaves. Common to pine woods, attached to cones of Scotch pine. Often overlooked.

H. ochraceum (ochracens, ochrey-yellow). Plate XXXI. Io.

Effuso-reflexed or entirely resupinate on dead branches, yellowish. P. I-5 in., thin, tough, zoned. Spines very minute. Whole plant easily separable from the matrix. Common in aut. and win. on trunks and branches, bramble stems, etc.

\section{SISTOTREMA}

(Gr. seistos, shaken; trema, a pore-from the irregular arrangement of the spines and their interstices)

S. confluens (from the confluent habit). Plate XXXI. 5 . $P$. I in., somewhat depressed, fleshy, white at first, then 
yellowish-brown; several pilei often confluent. Gill-like plates entire or toothed (jagged). S. about I in., attenuated below, often somewhat excentric. A scentless brittle species, usually terrestrial (sometimes investing sticks, moss, etc.), appearing in aut. Uncommon.

\section{IRPEX}

(Irpex, a harrow-from the supposed resemblance of the hymenial surface to that implement)

\section{I. obliquus (obliquns, oblique).}

Forms white or pallid patches on stumps and dead branches in win. Margin byssoid. Superficially like Poria vaporaria, but the teeth grow from folds arranged in a reticular manner; those in the centre of the patch are the larger, lying upon one another in an imbricated manner.

\section{RADULUM}

(Radix, a root-from the appearance of the hymenial processes)

R. orbiculare (ovbiculus, a small disc).

Forms resupinate white or yellowish patches, I-4 in. diam., on dead bark of various trees, chiefly birch, in aut. Often dingy flesh-colour in the second season. The tubercles are either scattered or in bundles, oblique or erect, tooth-like or obtuse.

\section{PHLEBIA}

(Gr. phleps, a vein-from the appearance of the hymenium)

P. merismoides (from the resemblance of the wrinkled hymenium to the Merismatæ section (non-British) of the genus Stereum).

Broadly effused, flesh-colour, orange or red, then dingy purple. $H$. tuberculated or folded, wrinkles crowded, white or downy beneath. Margin always delicate and very bright. Running over moss on trunks in aut. and win. Uncommon. 


\section{GRANDINIA}

(Grando, hail-from the appearance of the hymenium)

G. granulosa (gramum, a small seed-from the minutely granular hymenium).

Forms tan-coloured, broadly effused, thin adnate patches, 4-5 in. in diam., following the inequalities of the matrix. $H$. crowded with equal, rather sharp, minute granules; margin determinate. On dead branches of pine and other trees in aut. and win. Uncommon.

\section{POROTHELIUM}

(Gr.poros, a pore; thele, a teat-from the teat-like teeth of the hymenium)

P. confusum (from its having been confounded with other members of the genus).

Broadly and irregularly effused on fir-sticks, thin, whitish, dingy buff when dry. Papillæ very minute, not more than $\frac{1}{4}$ line long. Sum. and aut. in woods. Uncommon.

\section{ODONTIA}

(Gr. odons, odontes, a tooth-from the appearance of the hymenium)

O. fimbriata (fimbria, a fringe). Plate XXXI. 8.

Forms broadly effused patches of a cinnamon or beautiful fawn colour on fallen branches and moss in aut. and win. $H$. densely covered with minute granules (at length elongated), which are fringed at the tips, and traversed in perfect specimens by prominent branching veins. Uncommon.

KNEIFFIA

(After F. G. Kneiff, a mycologist).

K. setigera (seta, a bristle; gevo, to carry-from the bristles on the hymenium). 


\section{DESCRIPTION OF PLATE XXXII}

TYPES OF PORE-BEARING FUNGI (POLYPORACEÆ)

FIG. I.-Polyponus elegans, showing the abruptly black base of the excentric stem and the decurrent pores.

FIG. 2.-Polystictus perennis: young and confluent specimens.

FIG. 3.-Ditto: adult, showing the almost plane, zoned pileus.

Fig. 4.-Polvporus umbellatus, showing the numerous pileoli. (Onequarter natural size.)

FIG. 5.-Ditto: section showing the decurrent pores.

FIG. 6. -Merulius lacrymans on worked wood.

FIG. 7.-Strobilomy'ces strobiluceus.

FIG. 8. -Ditto: section showing the transverse dissepiments of the tubes, and the remains of the veil on the margin of the pileus.

Fig. 9.-Trametes gibbosa: group of imbricated plants.

FIG. IO.-Ditto: section showing the unequal tubes running at varying depths into the flesh cf the pileus.

FIG. Ir.-Dedalea quercina, showing the sinuous gill-like pore openings.

FIG. 12.-Ditto: section showing the long tubes. 


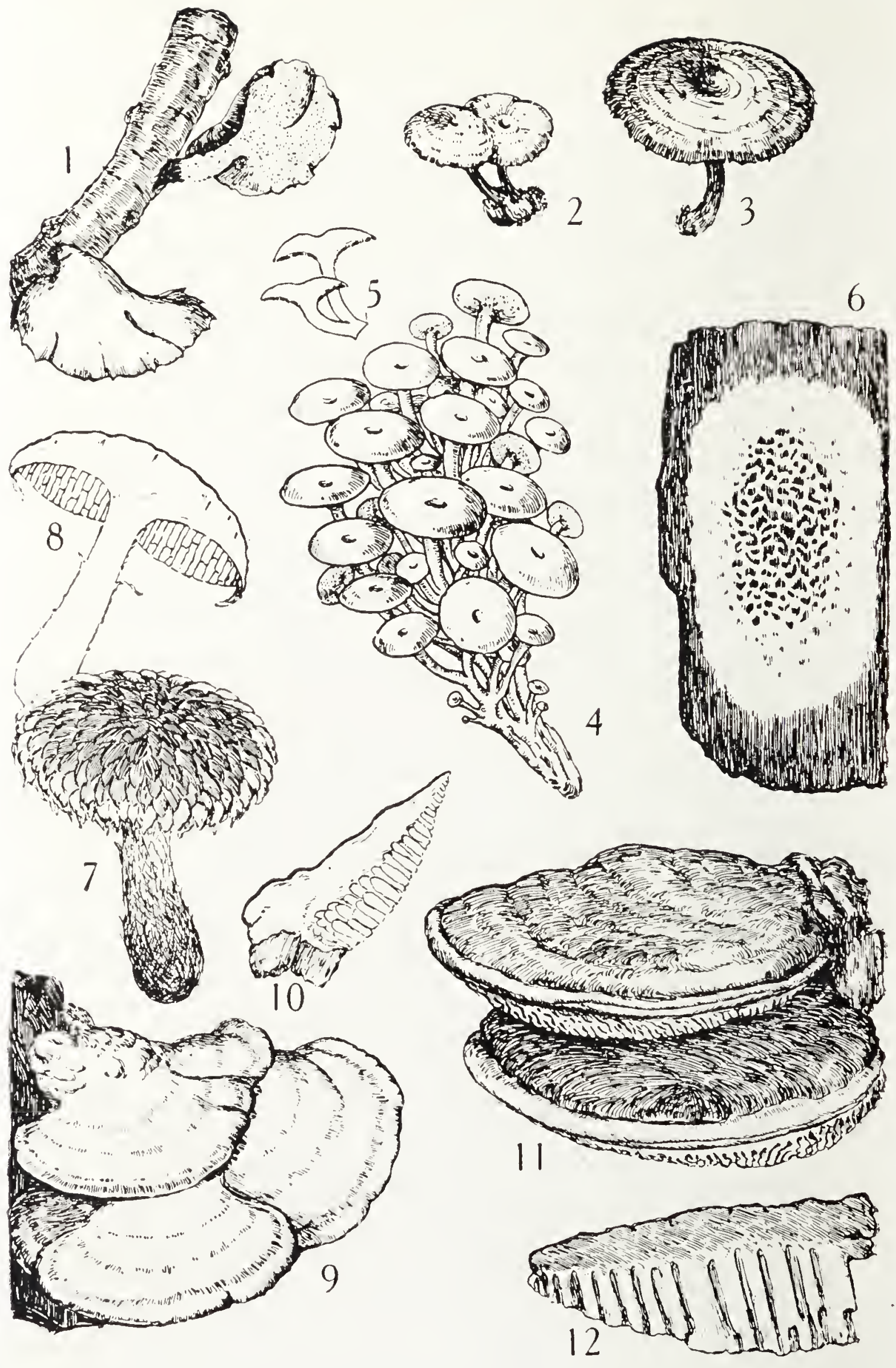


Forming patches (2-4 in. diam.) on dead wood; white at first, and then ochreous-ivory. Bristles minute, hyaline. Occurring throughout the year. Uncommon. Sometimes bearing a superficial resemblance to Grandinia gramulosa.

\section{MUCRONELLA}

(Diminutive of mucro, a sharp point-from its appearance)

M. calva (calva, the bald scalp-from the habit, a few scattered hairs).

A curious fungus consisting of very slender whitish or grey smooth spines, $\frac{1}{2}$-I in. long, growing in a downward direction on rotten pine wood. There is no resupinate portion; the thin film which is present at first soon becomes obsolete.

\section{POLYPORACER}

\section{(Pore-bearing Fungi)}

\section{KEY TO THE GENERA}

Merulius. Sporophore subgelatinous. Tubes very shallow, resembling anastomosing wrinkles.

Dædalea. Sporophore corky. Tubes very sinuous and labyrinthiform. Pores sinuous.

Trametes. Sporophore coriaceous. Tubes appearing as if immersed in the flesh of the pileus. Pores oval or elongate.

Poria.

Sporophore entirely resupinate, disclosing only tubes.

Polystictus.

Sporophore coriaceous or membranaceous, sessile. Tubes shallow and punctiform. Pores round.

Fomes.

Sporophore coriaceous or woody, sessile. Tubes formed in successive strata.

Polyporus. Sporophore fleshy or tough, with or without a stem Tubes not formed in successive strata.

Fistulina.

Sporophore fleshy, juicy, with lateral stem. Tubes quite separate from each other.

Strobilomyces. Sporophore fleshy, with a central stem. Pileus covered with large scales.

Boletus.

Sporophore fleshy, mushroom-like in shape. Tubes easily separable from the hymenophore. 


\section{MERULIUS}

(So called from the yellow, orange or partially black colour of the hymenium - the colours of the beali and plumage of the blackbird, memla)

M. lacrymans (lachryma, a tear-from the watery drops on the hymenium), "Dry Rot." Plate XXXII. 6.

Somewhat gelatinous. H. irregularly wrinkled, yellowishbrown or dark brown. F. stains paper red. Margin sterile, white or yellow. Forming effused patches, varying from 2 to $3 \mathrm{in}$. to a foot or more in diam., $\frac{1}{2}$ in. thick or more. Very variable. "Whole plant generally resupinate, soft, tender; at first very light, cottony, and white. When the veins appear, they are of a fine yellow-orange or reddish-brown, forming irregular folds, most frequently so arranged as to have the appearance of pores, but never anything like tubes, and distilling, when perfect, drops of water. Sometimes the pileus or substance of the plant, from its situation, produces pendent processes like inverted cones" (Greville). On worked wood, carpets, etc., in Britain always confined to houses and sheds. In a badly infected building the copious spores cover every object with a thin film of bright rustcoloured dust.

\section{DEDALEA}

(From the labyrinth made by Dadalos-in reference to the labyrinthine, intricate pores)

D. quercina (quevcus, oak-its habitat). Plate XXXII. I I.

Every part of a woody appearance and corky texture. P. 3-6 in., sessile, usually on a broad base. Por. at first rounded, becoming much contorted, elongated, deep and sinuous, the thick flexible dissepiments resembling gills. "Sometimes the whole plant is resupinate or decurrent, in which case the partitions are often elongated into tooth-like processes" (Berkeley). Occurring throughout the year on 
dead oak stumps and trunks, particularly the cut surface of stumps remaining where trees have been felled two or three years previously, occasionally appearing on squared timber. Has been found in peat beds and lake-side pile-dwellings. Very common.

\section{TRAMETES}

(From the generic distinction depending on the trama)

T. gibbosa (gibbus, gibbous-from its thiclness and convexity). Plate XXXII. 9.

P. I-6 in., concentrically zoned, minutely velvety, white, greyish with age; sometimes green, owing to the presence of a minute alga in the velvet. $F$. white and corky. Por. about $\frac{1}{4}$ in. deep, radially elongated, straight except at the base, where they are usually roundish or irregular, pale tan. Stumps, posts, etc., throughout the year. Not common.

T. Bulliardi (after Pierre Bulliard) is frequent on decaying alder.

$P$. and Por. whitish at first, becoming brown at maturity. If touched with ammonia, the pores instantly assume a beautiful but evanescent pink colour.

\section{PORIA}

(From the porous hymenium)

P. vaporaria (vapovavium, a stove-perhaps first observed in a hot-house). Plate XVI. 3.

Por. large, angular, whitish at first, then cream-colour. Forming broadly effused, thin, inseparable patches (up to 4 in. diam.) on dead trunks and branches, and on wounded surfaces of living branches, the white mycelium penetrating the bark. Said, by Hartig, to be very destructive in Germany to living spruce and pine, and having as bad a reputation as the "Dry-Rot" fungus. Common throughout the year. 


\section{POLYSTICTUS}

(Gr. polus, many; stiktos, punctured-from the punctures on the hymenium)

P. perennis (perennis, perennial). Plate XXXII. 2.

$P$. funnel-shaped at first, nearly plane at maturity, zoned, coriaceous, velvety, marked with little radiating lines, dull cinnamon, often bleached white when old. $S$. central up to $I_{2} \frac{1}{2}$ in., tough, velvety, thickened below, rusty brown. Pov. very small and very short, angular or roundish, at first with a white bloom, slightly decurrent. Aut. and win., lasting over until the following sum. Frequent on bare sandy spots, and especially where charcoal has been made in open places in woods, also on heaths. Often confluent; sometimes half a dozen plants may become united.

P. versicolor (from its variable colours), "Common Stump-flap." Plate I. 4-8.

P. I-3 in., horizontal, thin ( $\frac{1}{6}$ in.), flat, densely velvety, shining, concentrically zoned with various colours. Por. shining white at first; colour of ivory when old and becoming torn; often obsolete at the margin; bright orange or vermilion when attacked by the mould Hypomyces auvantius. Exceedingly common throughout the year on trunks, stumps, branches, etc. Very variable (see notes on p. I2). A new hymenium appears on the downward pileus of plants on a log which has been rolled over.

P. abietinus (abies, fir-from its habitat), "Purple Fir Polypore." Plate XXXIII. 2.

$P$. I-2 in., greyish-white, indistinctly zoned; margin often violet when young. $H$. at first a beautiful violet, becoming brownish in the centre. Por. much torn, toothed, and sinuous, except at the margin. Common on decaying fir trunks in aut. and win. Resupinate individuals often become confluent, and form a broad patch, with lobed margin. Differs from Poria violacea in the deeper and torn pores, and the reflexed margin. 


\section{FOMES}

(Fomes, touchwood or tinder-from the use of many species in kindling fire in olden times)

F. fomentarius (fomentum, tinder-for which it was formerly used), "Soft Tinder Fungus." Plate XXXIII. 7.

P. 3-8 in.; 3-5 in. thick at the base; distinctly sulcate concentrically, glabrous, thick, hard, and persistent. Dingybrown; margin white at first. $F$. rather soft, foxy rustcolour. T. very long, $\frac{1}{2}-2$ in., stratose, ferruginous. Por. sub-angular, minute; at first powdered with white; ferruginous at maturity. It tapers from the thick base to the centre, hence is always triangular in section. Occurring throughout the year on the trunks of various trees. It has been found in peat beds and lake-side pile-dwellings.

F. igniarius (ignis, fire-from its former use as tinder), "Hard Tinder Fungus."

$P$. globose and tubercular at first, with a thin hoary covering; then thin hoof-shaped, reddish-brown or blackishbrown, with a very hard cuticle ; margin rounded. F. zoned, ferruginous, very hard, "not fit for converting into amadou." T. I-2 in. long, very small, stratose, cinnamon; when senile filled with white mycelium. Por. very minute, rounded; hoary at first ; cinnamon at maturity. On trunks of various trees throughout the year; commonly seen on old fruit trees. It has been found in peat beds and lake-side piledwellings.

F. annosus (ammus, a year-growing in yearly strata), "Fir-root Polypore." Plate XII.

$P$. convex, then plane, I-I 2 in., brown with whitish margin in the first year, afterwards glabrous blackish-brown. F. rather thick, white. Por. about $\frac{1}{4}$ in. long, pure white at first, then pallid. Very variable; sometimes encrusting twigs and leaves; entirely resupinate when growing beneath a log or on the exposed surface of a root. Extremely common 
about the roots of decaying trees, stumps, etc., especially pine. A dangerous parasite, see notes on p. 28.

F. ferruginosus (fermm, iron-from its rusty colour). Plate XXXIII. 4.

Broadly effused and closely adnate, $\frac{1}{4}-\frac{1}{2}$ in. thick, sometimes with reflexed margin, bright ferruginous-brown at first, darker when old. Por. subrotund, sometimes torn, long. $F$. almost obsolete. Common on trunks, especially the under surface of dying oak branches not detached from the tree; sometimes forming patches $2 \mathrm{ft}$. in length.

F. ribis (vibis, currant) forms the well-known sporophores on old currant and gooseberry bushes, F. ulmarius (ulmus, elm), the effused whitish strata on old elms, and $F$. fraxinens (fraxims, ash), the large, strong-smelling, reddish-brown sporophores on old ash trunks.

\section{POLYPORUS}

(Gr. polus, many; poros, a tube-from the many pores of the hymenium)

P. Schweinitzii (after Ludwig David von Schweinitz). Plate XIII. 6.

$P .4$-I 2 in., hairy, dark brown; margin at first yellowishgreen; when old and dry, reddish-brown. $F$. thick and spongy at first, becoming dry and bright brown. $T \cdot \frac{1}{4}-\frac{1}{2}$ in. long. Por. large and very angular, often elongate and sinuous, yellow with a tinge of green, becoming brownish when bruised, reddish-brown when dry. $S$. usually central and distinct. Spore mass pure white. Not uncommon in the South of England at the base of living larch trees. A deadly parasite. The stem is not invariably central, and sometimes is quite obsolete. When growing within a hollow trunk, it is often attached by a broad lateral base, and the pilei growing into one another form a huge tuft. I have seen specimens 15 in. diam., and as many in depth at the base. 
P. squamosus (squama, a scale-from the scaly pileus), "Dryad's Saddle." Plate XXXIII. 6.

$P$. fan-shaped, developing from a subglobose, blackish knob, 6-12 in. or more across, pale yellow, with large adpressed dark scales. $F$. thick, white, firm. Por. minute at first, becoming angular, torn and decurrent, yellowish white. S. excentric or lateral, short, thick, corky, black at the base. "This species sometimes attains to an enormous size. My esteemed friend, Dr. Hooker, relates an instance, given him by Mr. Hopkirk, of one which measured $7 \mathrm{ft}$. 5 in. in circumference, and weighed, after having been cut four days, 34 lbs. avoirdupois. It was only four weeks in attaining the above size, gaining thus an acquisition of weight of above I 1b. $3 \mathrm{oz}$. in the day" (Greville). Common on stumps and trunks, especially elm and ash. Smell disagreeable, not appearing in win.

P. elegans (from its elegant shape). Plate XXXII. x.

P. 2-4 in., often angular, pliant at first, soon hard, smooth, shining, pale yellow, or dull orange. $T$. minute, yellowish white, often decurrent to the black part of the stem. S. $\frac{1}{2}-1 \frac{1}{2}$ in., slender, excentric or lateral, smooth, pallid above, abruptly black below, rooting. Frequent in sum. and aut. on stumps and trunks, especially birch. The var. mummularius is smaller $(P$. less than $I$ in.), with a regular even margin. $P$. varius, occurring chiefly on ash, and $P$. picipes (disc chestnut colour) for the most part on willow, are closely allied species, difficult at times to separate from the above.

P. umbellatus (the many stems and pileoli form an umbel), "Umbellate Polypore." Plate XXXII. 4.

A rare species, which is delineated as an example of the complexity of the sporophore in some members of the family. Numerous umbrella-shaped dingy pilei $\left(\frac{1}{2}-2\right.$ in. diam.), with elongated whitish stems (upon which the minute white pores are decurrent), spring from a common, thick, root-like base, forming a dense tuft 4-9 in. across, which might easily at 
first sight be mistaken for a tuft of agarics. In woods, in early aut.; terrestrial, or on stumps.

P. sulphureus (from the sulphur colour), "Cheesy-yellow Polypore." Plate XXXIII. 5.

$P$. undulate, tufted and imbricated, 6-I 2 in. diam. or more, yellowish-orange or reddish. $F$. thick, yellow becoming white, of a cheesy consistency, never leathery. $T$. up to $\frac{1}{2}$ in. long. Por. minute, plane, always a beautiful sulphur-yellow. The pileus is covered with crystals of oxalate of lime. A large showy species; frequent on living trunks in aut. and early wim.; one of the few fungi that attack the yew. Brittle. Smell disagreeable, becoming very powerful when drying.

P. betulinus (betula, birch - its habitat), "Birch-tree Polypore." Plate XIII. 7.

$P$. corky, hoof-shaped, whitish at first, then pale reddishbrown, zoneless, glabrous, margin incurved, 3-8 in. diam. or more. F. white, very thick. Pov. up to $\frac{1}{4}$ in. deep, unequal, whitish. Very common on living and dead birch. Sometimes the hymenium is attacked by parasitic moulds, Hypomyces rosellius and Hypocrea ochracea.

P. fumosus (fumosis, smoky-from its colour). Plate XXXIII. I.

P. 2-5 in., horizontal, often imbricated, effused behind, smoky grey. F. whitish, fibrous, rather corky, up to $\frac{1}{4}$ in. thick. Pov. shallow, small, rounded, greyish-white, darker when bruised, not becoming black in drying. Common in late aut. and early win. on old trunks and stumps.

P. adustus (aduvo, to burn-from the scorched appearance) differs from the above in the thinner substance and very minute pores which become blackish when dry.

The bay-brown species which frequently forms enormous imbricated flaps at the base of living beeches in aut. is $P$. gigantens. 


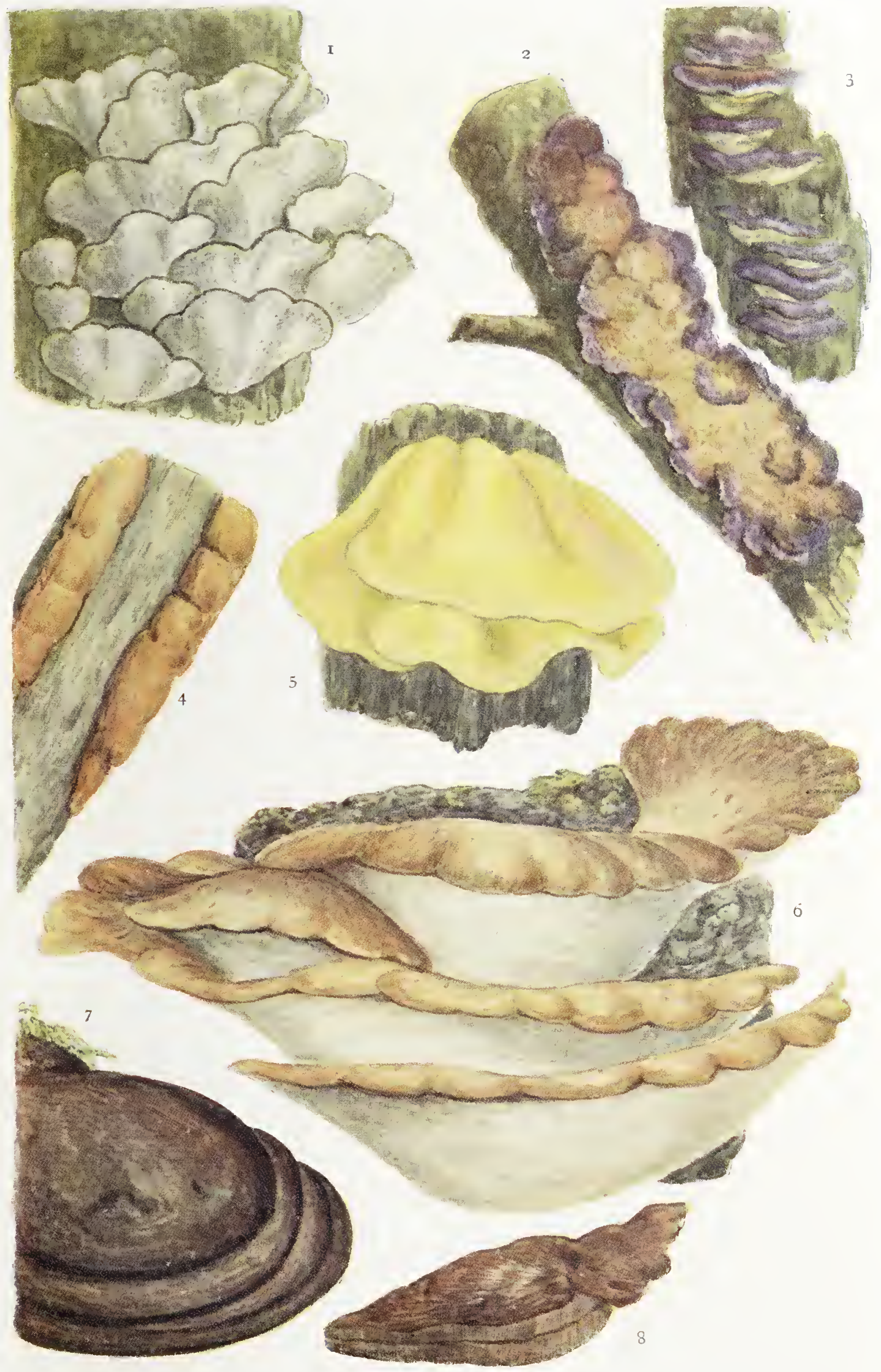




\section{DESCRIPTION OF PLATE XXXIII}

\section{COMMON POLYPORES}

FIG. I.--Polyporus fumosus: imbricated sporophores growing from the side of a log; tilted to show the greyish hymenial surface.

FIG. 2.-Polystictus abietinus: confluent and resupinate plants forming a large patch on the lower surface of a fallen branch.

FIG. 3.-Ditto: an imbricated form growing on a dead but erect trunk of Scotch pine.

FIG. 4.--Fomes fermuinosus forming resupinate patches on the inner surface of a dead oak branch.

FIG. 5.-Polyporus sulphureus. (One-quarter natural size.)

FIG. 6.-Polyporus squamosus: group of imbricated plants. (Oneeighth natural size.)

FIG. 7.--Fomes fomentarius. (One-quarter natural size.)

FIG. 8.-Ditto: section showing the stratose tubes. (One-quarter natural size.) 


\section{FISTULINA}

(Fistula, a pipe-from the pipe-like character of the tubes)

F. hepatica (Gr. hepatikos, of the liver-from the liver-like appearance), "Liver" or "Beef-steak" Fungus. Plate XV.9.

$P$. usually tongue-shaped, attached by a broad base, or having somewhat of a stem, 3-20 in., 2-3 in. thick, blood-red. $F$. thick, soft, marbled red and whitish like beetroot. Por. at first pale, then red. Spore mass salmon colour. On living trunks of various trees, chiefly oak, in ant. The mycelium persists for a long time, and sporophores emerge from the same spot on a tree for many consecutive years. Often of great size; Berkeley alludes to one of nearly 30 lbs. weight. This species is remarkable amongst the Polyporaceæ in its perishable nature, becoming putrid in less than a month after its first appearance. Frequent. A well-known esculent.

\section{STROBILOMYCES}

(Gr. strobilos, a fir cone ; mukes, a fungus - from the supposed resemblance of the pileus to a fir cone)

S. strobilaceus (from the top of the pileus being covered with scales like a pine cone, strobilos), "Fir-cone Bolet." Plate XXXII. 7.

$P$. fleshy, 2-5 in., densely covered with large umber-brown scales, margin fringed with fragments of the white veil. $F$. blackish or brown when broken. T. white, deep, angular, adnate, sometimes shorter round the stem. Pov. white. S. 3-6 in., $\frac{1}{2}-\frac{2}{3}$ in. thick below, solid, white above brown at the base. A rare species frequenting pine woods, etc., and open grassy places. 


\section{BOLETUS}

(Gr. bolos, a clod-from the clod-like pileus)

B. luteus (hters, yellow-the colour of the tubes). Plate VII. Iо.

$P$. 3-4 in., at first covered with a thick purplish gluten, which soon vanishes, leaving it paler. $F$. thick, whitish. $T$. about $\frac{1}{4}$ in. long, adnate, openings roundish, yellow, tinged with cinnamon when old. S. 3-4 in., stout, yellow and glandular above the ring, whitish below. $R$. large, membranaceous, persistent, whitish, sometimes tinged pink. Very common in pine woods in sum. and aut.; at once recognised by the very glutinous brown pileus and the ample ring.

B. elegans (from its elegant shape). Plate XXXIV. 8.

P. 2-4 in., tawny-golden or clear yellow. $F$. thick, pale yellow. $T$. slightly decurrent, $\frac{1}{4} \mathrm{in}$. long; openings uniformly minute, deep sulphur-yellow. S. 3-4 in., stout, golden-yellow ; dotted above the ring; streaked or stained with red below it. $R$. whitish, imperfect, fugacious. Common in sum. and aut. in fir woods, especially under larches.

B. flavus (flavus, light yellow) is chiefly distinguished from the preceding by the abruptly adnate tubes, large angular pores, and the reticulations on the stem above the membranaceous ring.

B. chrysenteron (Gr. chvisos, gold; enteva, inward partsfrom the golden-yellow colour of the flesh), "Red-crack Bolet." Plate XXXIV. 4 .

$P$. 2-4 in., almost plane at maturity, at first covered with a dense brownish-olive tomentum, which eventually cracks into polygons; cracks red. $F$. rather thin, pale yellow, red just beneath the tomentum, changing slightly to blue. $T$. up to $\frac{1}{2}$ in. long, subadnate, dull yellow, blue when bruised; openings angular, largest near the stem. S. 2-3 in., stout, rigid, very firm, fibroso-striate, yellow, more or less tinged 


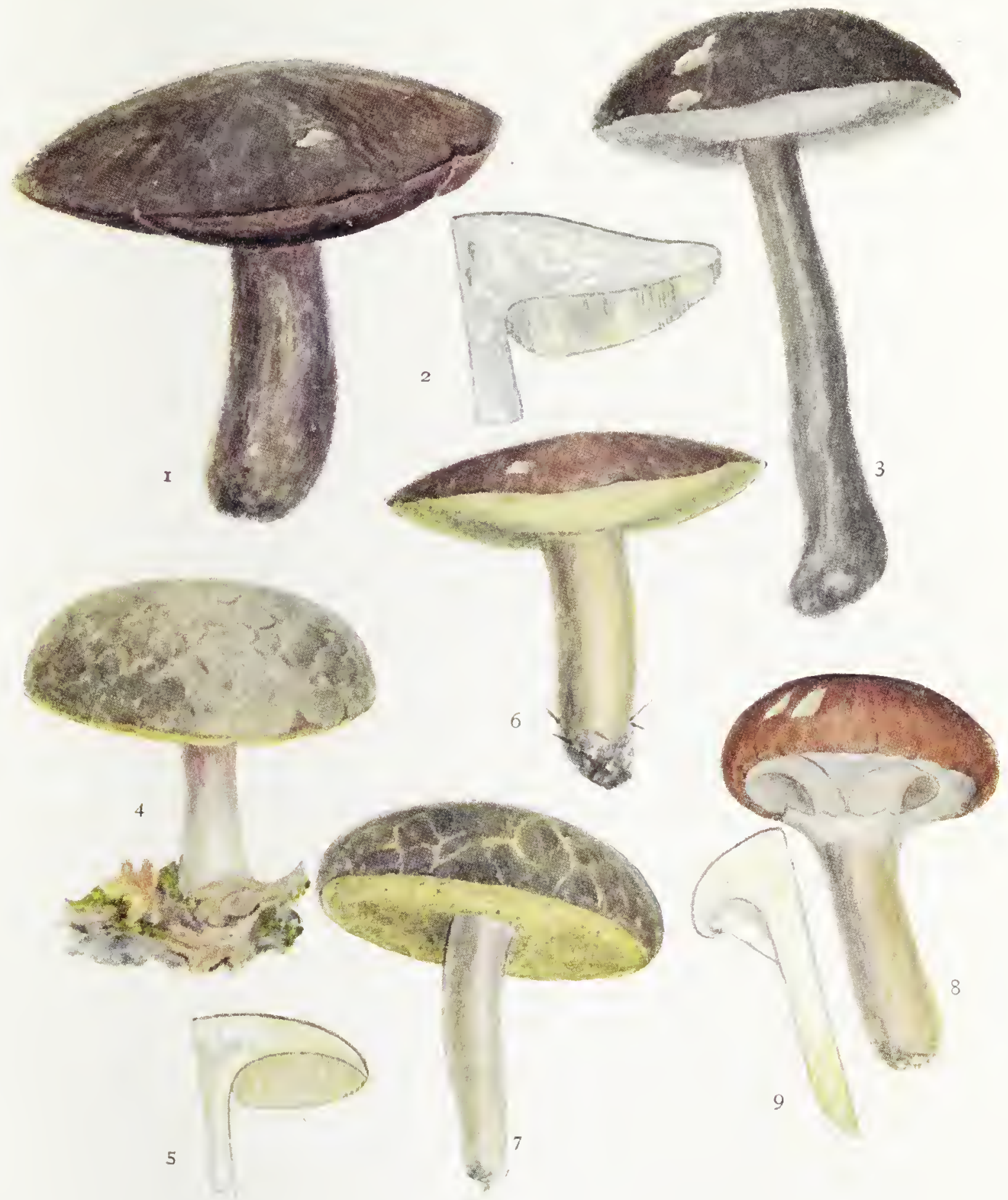




\section{DESCRIPTION OF PLATE XXXIV \\ COMMON BOLETS}

FIG. I.-Boletus luvidus.

FIG. 2.-Ditto: section showing the bluing of the flesh.

FIG. 3.-B. scaber.

FIG. 4.-B. chrysenteron.

FIG. 5.-Ditto: section showing the red flesh below the cuticle.

FIG. 6.-B. badius.

FIG. 7.-B. subtomentosus.

FIG. 8.-B. elegans: young plant, showing the veil breaking away and forming a ring round the stem.

FIG. Q.-Ditto: section showing the slightly decurrent tubes. 
with red. Common in ant. in woods and pastures. The var. namus ( $P$. I in.) differs in the flesh, becoming red when cut, and in the elongated sinuous openings of the tubes. The var. versicolor ( $P$. I $\frac{1}{2}$ in.) may be at once recognised by the beautiful rose-pink pileus.

B. radicans (vadix, root) differs from chrysenteron chiefly in the permanently incurved margin of the pileus, flesh not reddening, smaller pores, and stouter stem tapering downwards into a rooting base.

B. subtomentosus (from the somewhat tomentose pileus), "Yellow-crack Bolet." Plate XXXIV. 7.

Somewhat resembling $B$. chrysenteron, but known by the absence of red under the tomentum; hence the cracks are yellowish, never red. Common in woods in aut.; sometimes growing from the interior of beech-nuts. In the var. vadicans the pileus is bright yellowish-green; stem whitish below, yellow and strongly grooved above.

B. parasiticus (from its parasitic habit). Plate XI. 5 .

$P$. 2-2 $\frac{1}{2}$ in., dry silky, yellowish tan. $F$. reddish. $T$. yellow, then reddish-orange, openings minute. $S . \frac{1}{2}-2$ in., incurved, hollow; colour of the pileus, flesh yellow. Parasitic on the earth-balls (Sclevoderma vulgare and vervucosum). At once known by the peculiar habitat. Said to be uncommon, but is probably often overlooked, the colour of the pileus exactly resembling that of the peridium of its host. Autumnal.

B. badius (badius, bay-brown). Plate XXXIV. 6.

$P$. 3-5 in., rather viscid in wet, soon becoming dry and shining, bay-brown. $F$. thick ( $I-2$ in.), white, slightly tinged blue near the tubes, and faintly red above when cut. $T$, about $\frac{2}{3}$ in. long, depressed around the stem, yellow, becoming green when bruised; openings yellowish, at once becoming deep bluish-green when bruised. S. 2-3 in., mottled and streaked with brown, never reticulated. In woods, chiefly pine, in aut. Common. 
B. luridus (from the lurid colours), "Lurid Bolet." Plate XXXIV. I.

$P .3-6$ in., olivaceous, brick-red, dingy-brown, etc., minutely tomentose. $F$. very thick, firm, yellow, instantly changing to indigo-blue when cut. T. up to $\frac{1}{2}$ in. long, almost free, greenish olive, openings minute, roundish, vermillion, orange, or brown. S. 2-5 in., very stout, usually bulbous below, reddish or yellow with red blotches, sometimes vaguely reticulated with crimson-red. In woods, under trees in pastures, and in hedgerows in aut. Very common and very poisonous.

Concerning the curious bluing of the flesh in this and other species, Massee writes: "The peculiar property possessed by the flesh of some species in becoming a more or less intense blue when cut or broken depends on the presence of two distinct substances in the flesh-one, a resinous substance that becomes blue when brought in contact with ozone; the other, a substance soluble in water, which ozonises the oxygen of the air, and then effects a combination with the resin, to which it gives up its oxygen in the form of ozone, the result being a more or less intense blue coloration." The resinous substance is guaiacum; the oxidising ferment is known as tyrosinase. The phenomenon is not confined to the Boleti, but is possessed by other fungi in the various groups.

B. scaber (scaber, rough - in allusion to the stem), "Porcinello." Plate XXXIV. 3.

$P .3-6$ in., viscid when moist, white, cinereous, olive-brown, etc. $F$. thick in the centre, white, unchangeable. $T \cdot \frac{1}{2} \cdot \frac{3}{4}$ in., long, almost free, openings irregular, subangular, white at first, then dingy-brown. S. 5-7 in., conical upwards, pale, rough, with black or orange scales; sometimes coarsely lined. Common in woods in late sum. and aut. Often gregarious. Esculent; the Porcinello or Albavello of Italian markets.

B. versipellis (verto, to turn; pellis, the skin-from the changeable colours of the pellicle) somewhat resembles the 


\section{DESCRIPTION OF PLATE XXXV}

\section{DIAGRIMS SHOWING THE RELATION OF THE GILLS TO THE STEM}

FIG. I.-Clandopus variabilis: pileus resupinate at first, the gills radiating from the point of attachment; stem absent.

Fig. 2.-Agaricus campestris: gills crowded, broad and free.

FIG. 3.-Collybia butyracea: gills slightly adnexed or almost free.

FIG. 4.-Clitocybe iaccata: gills broadly adnate.

Fig. 5.-Mycena pura : gills adnexed and broadly sinuate.

FIG. 6. - Omphalia umbellifera: gills decurrent and distant.

Fig. 7.-Clitocybe pithyophila: gills very decurrent and narrow.

FIG. 8.-Marasmius rotula: gills very distant; connected behind by a collar, which is quite free from the stem.

FIG. 9.-Lepiota froceva: gills remote.

FIG. I o.-Tricholoma terveum: gills sinuate or emarginate. 


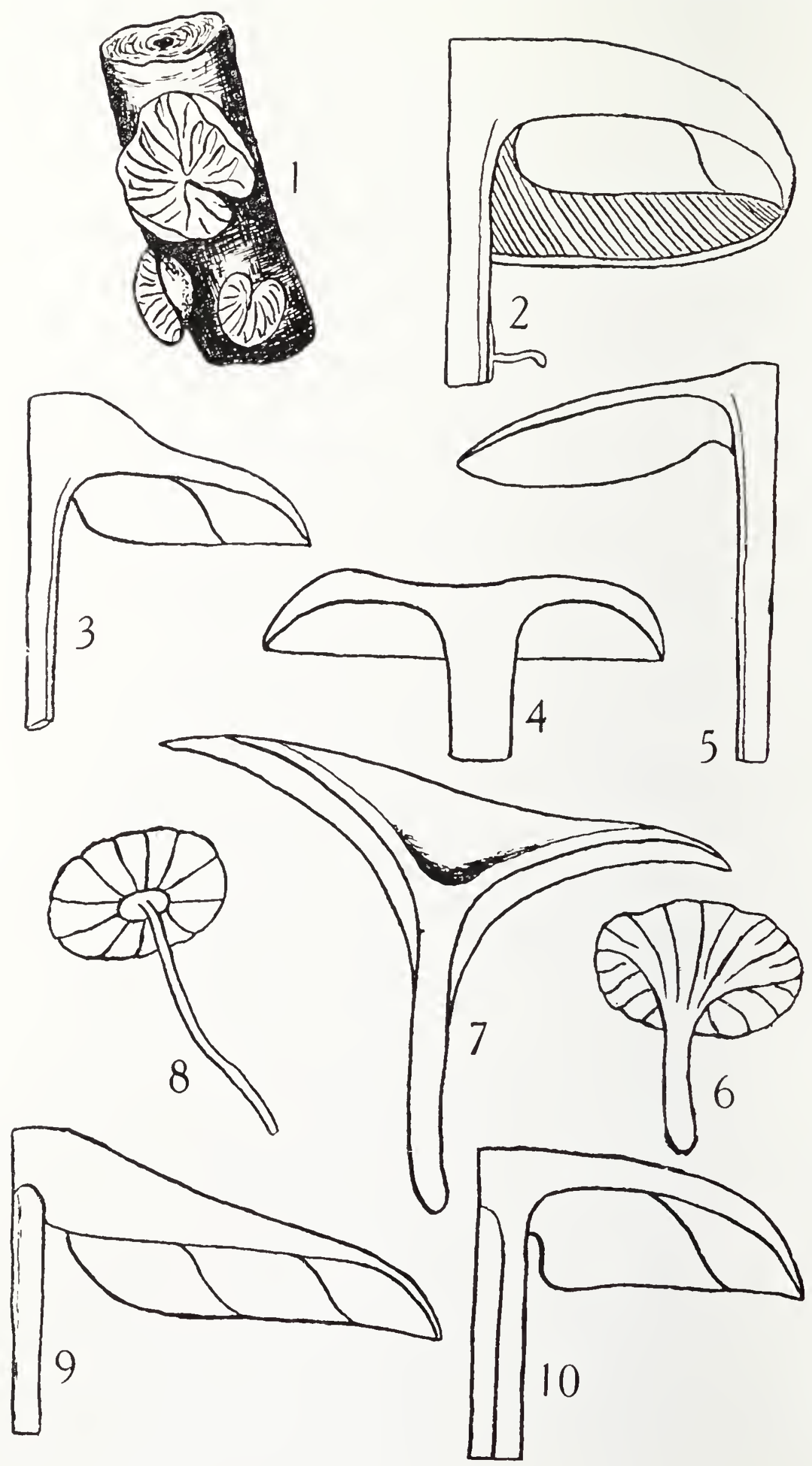

DIAGRAMS SHEWINC MODHS OF GILI, ATMACHMENT 


\section{DESCRIPTION OF PLATE XXXVI}

\section{TYPES OF GILL-BEARING FUNGI (AGARICACE $Æ$ )}

FIG. I.-Lepiota procercl : young and mature plants.

FIG. 2.-Ditto: section showing the remote gills.

FIG. 3.-Amanitopsis vaginata.

FIG. 4.-Ditto: section showing the free gills and volva.

FIG. 5.--Amanita mappa, young.

FIG. 6.-Ditto, mature, showing the deflexed ring and large bulbous volva.

FIG. 7.-Russula ochroleuca.

FIG. 8.-Ditto: section showing the broad adnexed gills.

Fig. 9.--Pleurotus septicus, an apparently resupinate species, but is connected with the matrix only by a very minute stem.

FIG. Io.-Pleurotus ulmarius: stem excentric. 


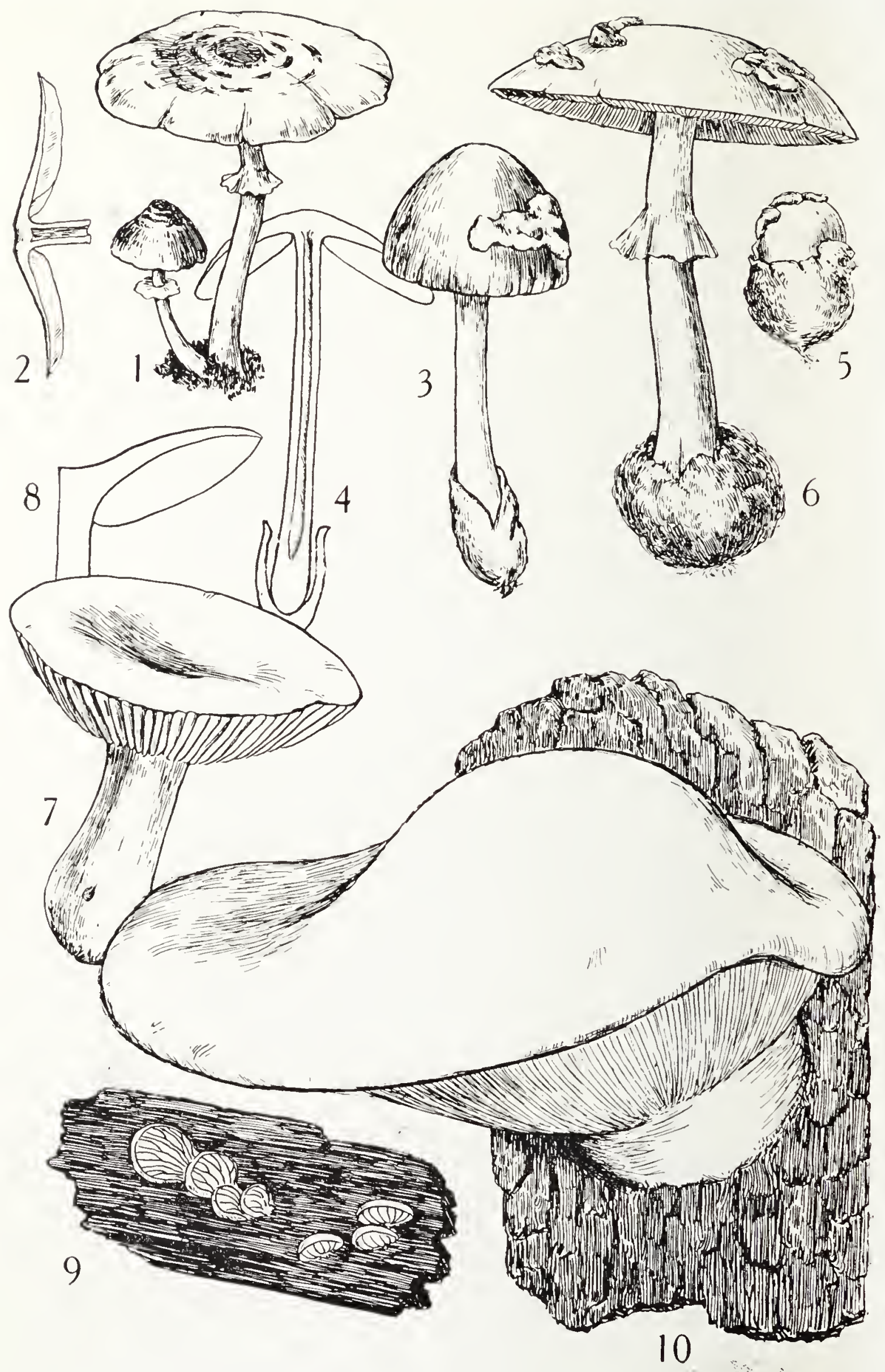


preceding, but is usually larger, stouter, and more brightly coloured. $P$. reddish-orange or reddish-brown. S. whitish, prominently sprinkled with almost black squamules.

B. piperatus (pipev, pepper-from the taste) may be known by the cinnamon-brown, large and irregularly angular pores, and the acrid pungent taste. In woods in aut.; sometimes tufted. Mycelium yellow.

B. bovinus (bos, an ox-from the buffish red pileus), a clustered or gregarious species frequent in heathy pine woods, has a thin reddish-yellow pileus and long slender stem (2-4 in.). The involute margin of the pileus overlaps the tubes.

B. edulis. Plate XV. 8.

P. 4-6 in., brownish. F. very thick, white. S. 2-4 in., up to $2 \mathrm{in}$. diam., pale brown, with white reticulations above. The Cèpe of French markets. Common in woods in aut. Sometimes attacked by the yellow mould Hypomyces chrysospermus.

\section{Family AGARICACEÆ}

(Gill-bearing Fungi)

\section{KEY TO THE GENERA}

A. Plant fleshy, more or less firm, rotting at maturity. Gills free. Stem central, its substance distinct from that of the pilens.

\begin{tabular}{|c|c|c|}
\hline Amanita. & Stem with ring and volva ... & Leucosporæ. \\
\hline Acetabularia. & 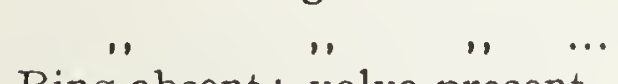 & ... Ochrosporæ. \\
\hline Amanitopsis. & Ring absent; volva present & ... Leucosporæ. \\
\hline Volvaria. & ,. & ... Rhodosporæ. \\
\hline Chitonia. & $n$ & ... Porphyrosporæ \\
\hline Lepiota. & Ring present ; volva absent & ... Leucosporæ. \\
\hline Annularia. & ", & ... Rhodosporæ. \\
\hline Agaricus. & 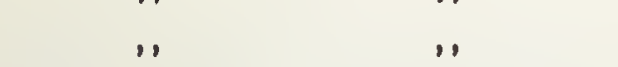 & ... Porphyrosporæ \\
\hline Chlorospora. & Ring absent; volva absent & ... Chlorosporæ. \\
\hline Pluteus. & ", & ... Rhodosporæ. \\
\hline Pluteolus. & ,. & ... Ochrosporæ. \\
\hline Pilosace. & " & ... Porphyrosporæ \\
\hline Schulzeria. & 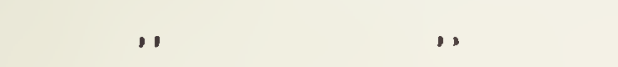 & Leucosporæ. \\
\hline
\end{tabular}


B. Plant fleshy, more or less firm, rotting at maturity. Stem central, its substance confluent with, and similar to, that of the pileus.

Armillaria.

Pholiota.

Stropharia.

Anellaria.

Cortinarius.

Tricholoma.

Entoloma.

Hebeloma.

Inocybe.

Hypholoma.

Panæolus.

Clitocybe.

Clitopilus.

Flammula.

Gomphidius.

Paxillus.

Cantharellus.

Nyctalis.

Lactarius.

Russula.

Hygrophorus.

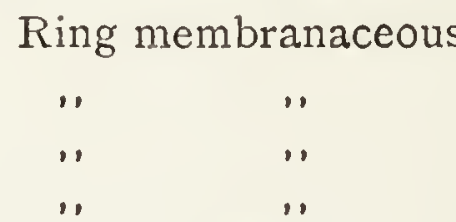
... ... Leucosporæ.
... ... Ochrosporæ.
... ... Porphyrosporæ.
... ... Melanosporæ.

Ring cobwebby, thread-like, or vanishing ...

... Ochrosporæ

(rust colour).

Ring absent. Gills sinuate

... Leucosporæ.

... Rhodosporæ.

.. Ochrosporæ.

Ring absent. Gills sinuate. Surface of pileus somewhat fibrillose ... Ochrosporæ.

Ring absent. Gills sinuate _.. Porphyrosporæ.

Ring absent. Gills sinuate. Margin of pileus exceeding the gills

Gills decurrent, edge acute. Stem with a fibrous outer coat

Gills decurrent, edge acute. Stem with a fibrous outer coat

Gills decurrent, edge acute. Stem with a fibrous outer coat

Gills decurrent, edge acute. Stem with a fibrous outer coat

Melanosporæ.

Leucosporæ.

Rhodosporæ.

Ochrosporæ.

Melanosporæ

(fuscous).

Stem with a fibrous outer coat.

The decurrent gills separating readily from the pileus ... ... Ochrosporæ.

Gills decurrent with blunt edge ... Leucosporæ.

Gills adnate. Plants parasitic on other agarics

Flesh and gills containing milk $\ldots$

Without milk; gills very rigid and brittle

C. Plant fleshy, more or less firm, rotting at maturity. Stem central, gristly, its substance confluent with, but dissimilar from, that of the pileus.

Omphalia.

Eccilia.

Tubaria.
Gills decurrent

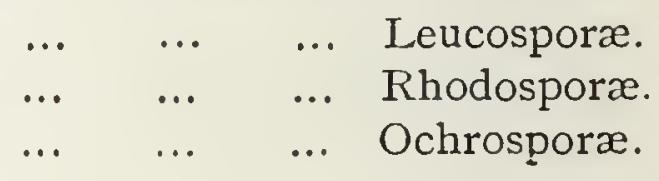


Collybia. Gills not decurrent. Margin of the pileus at first involute ... ...

Leptonia. Gills not decurrent. Margin of the pileus at first involute ... ... Rhodosporæ.

Naucoria. Gills not decurrent. Margin of the pileus at first involute ... ... Ochrosporæ.

Psilocybe. Gills not decurrent. Margin of the pileus at first involute ... ... Porphyrosporæ.

Mycena. Gills not decurrent. Margin of the pileus pressed to the stem at first

Nolanea. Gills not decurrent. Margin of the pileus pressed to the stem at first Rhodosporæ.

Galera. Gills not decurrent. Margin of the pileus pressed to the stem at first

Psathyra. Gills not decurrent. Margin of the pileus pressed to the stem at first Porphyrosporæ.

Psathyrella. Gills not decurrent. Margin of the pileus pressed to the stem at first Melanosporæ.

Bolbitius. Gills moist, dissolving at maturity . Ochrosporæ (some pink).

Coprinus. Gills dripping away at maturity ... Melanosporæ.

D. Plant fleshy, move or less firm, rotting at maturity. Stem not central absent from some species.

$\begin{array}{lllllllll}\text { Pleurotus } & \ldots & \ldots & \ldots & \ldots & \ldots & \ldots & \ldots & \text { Leucosporæ. }\end{array}$

$\begin{array}{llllllll}\text { Claudopus } & \ldots & \ldots & \ldots & \ldots & \ldots & \ldots & \text { Rhodosporæ. }\end{array}$

$\begin{array}{llllllll}\text { Crepidotus } & \ldots & \ldots & \ldots & \ldots & \ldots & \ldots & \text { Ochrosporæ. }\end{array}$

E. Plant tough, leathery, or corky, not rotting at maturity.

I. Stem central.

$\begin{array}{lllllll}\text { Marasmius. } & \text { Gills simple } & \ldots & \ldots & \ldots & \text {... } & \text { Leucosporæ. }\end{array}$

Xerotus. Gills branched $\quad \ldots \quad \ldots \quad \ldots \quad$,.

2. Stem not central; absent from some specres.

\begin{tabular}{|c|c|c|}
\hline \multirow{3}{*}{$\begin{array}{l}\text { Lentinus. } \\
\text { Panus. } \\
\text { Trogia. }\end{array}$} & Gills toothed ... & Leucosporæ. \\
\hline & Gills not toothed & " \\
\hline & $\begin{array}{ccccc}\text { Gills crisped } & \text { or channelled longi- } \\
\text { tudinally } & \ldots & \ldots & \ldots & \ldots\end{array}$ & \\
\hline \multirow{3}{*}{$\begin{array}{l}\text { Schizophyllum. } \\
\text { Lenzites. }\end{array}$} & Gills splitting longitudinally & " \\
\hline & Gills woody, sometimes forming & \\
\hline & irregular pores & " \\
\hline
\end{tabular}




\begin{tabular}{|c|c|}
\hline 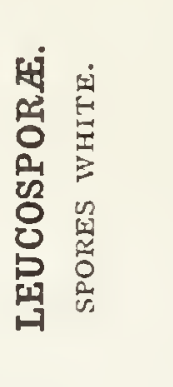 & 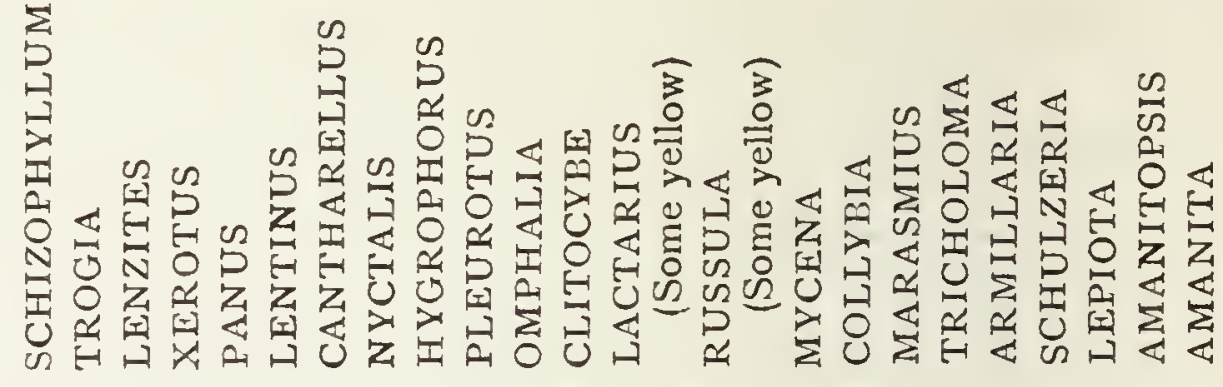 \\
\hline 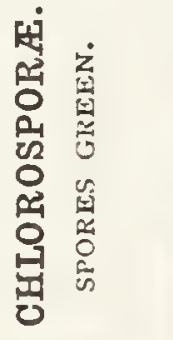 & 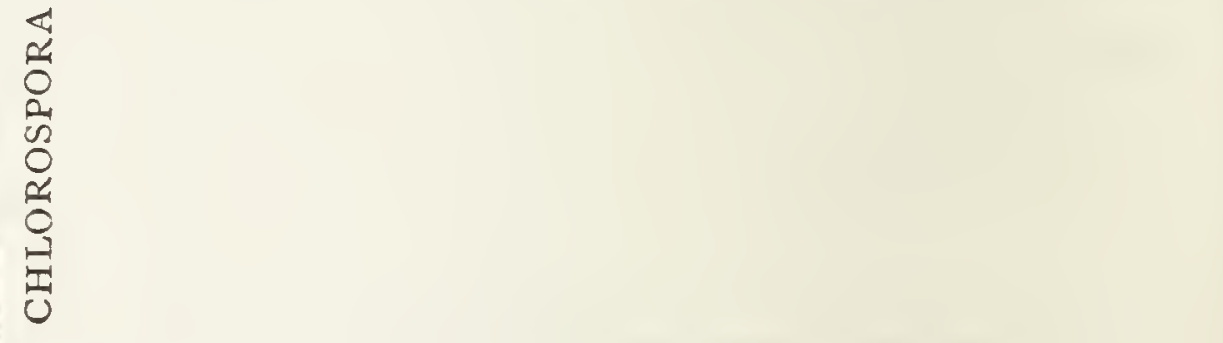 \\
\hline 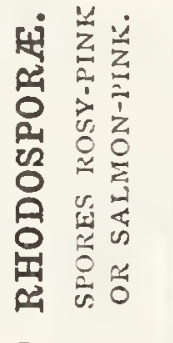 & 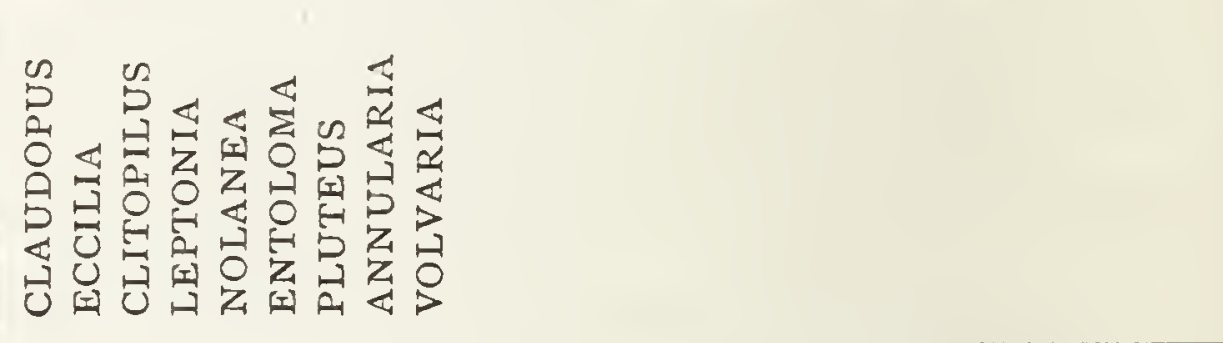 \\
\hline 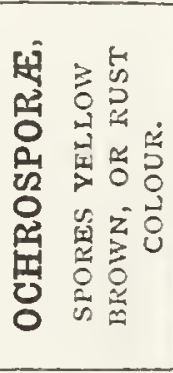 & 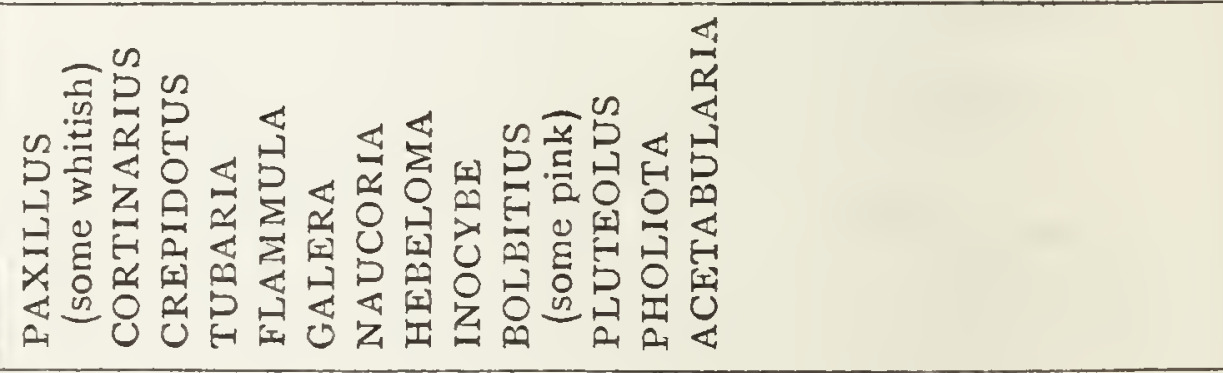 \\
\hline 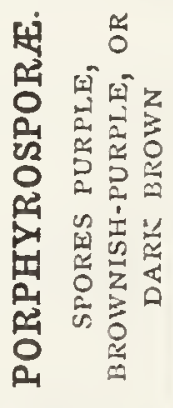 & 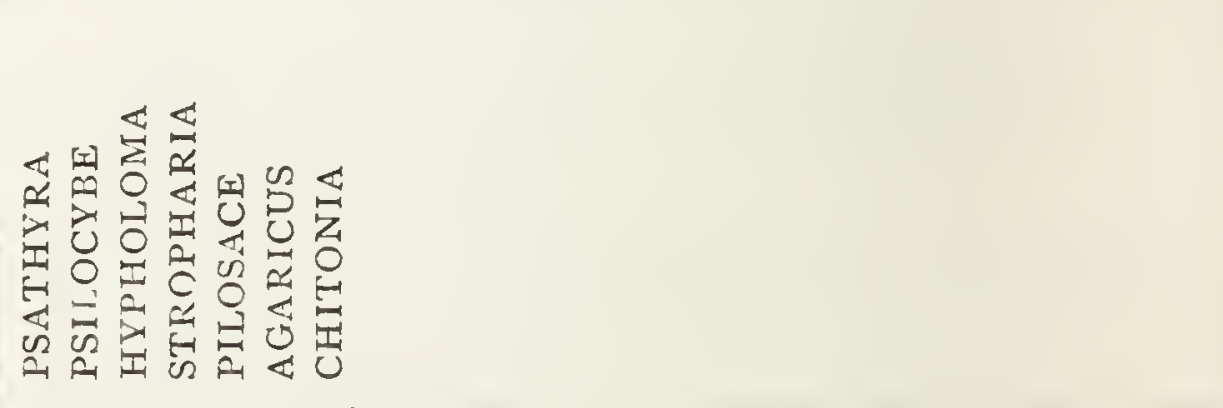 \\
\hline 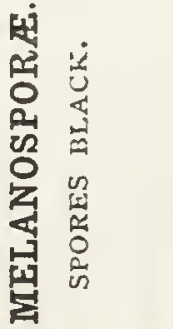 & 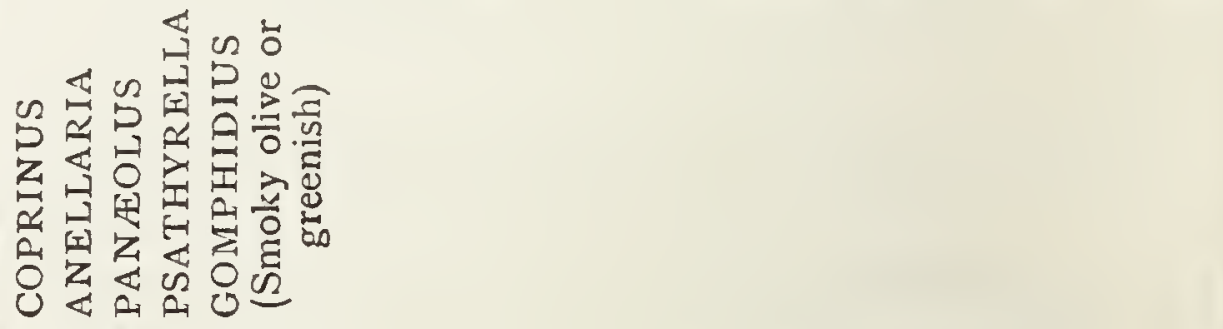 \\
\hline
\end{tabular}




\section{MELANOSPOR王}

Spores black. Gills black or dark grey, speckled with the spores; never tinged purple at maturity.

\section{COPRINUS}

(Gr. kopros, dung-from the habitat.)

C. comatus (coma, a hair-from the shaggy pileus), "Maned Inkcap." Plate XV. II.

P. 3-4 in. high, cylindrical; at length conical, or bellshaped; at first even, whitish; during growth the cuticle becomes torn into large shaggy scales, and assumes a reddish-brown tint. $G$. almost free, $\frac{1}{2}$ in. broad, crowded, white, then pinkish, becoming black, and melting away with the pileus into an inky black fluid. $S$. 4-6 in., slender, white, erect, hollow; somewhat bulbous below; bulb solid. $R$. movable. Gregarious, not tufted; often near houses; not appearing in win. I have on several occasions seen it in large numbers in asparagus beds. It is sold in American markets at Boston as the "English mushroom."

C. atramentarius (atramentum, ink-from the inky fluid into which the gills dissolve), "Common Inkcap." Plate XXXVII. 7-IO.

$P$. up to $3 \frac{1}{2} \mathrm{in}$. high, plicate, greyish, mealy and brownish at the apex. $G$. crowded, quite free, broad, white at first, finally black, with a suggestion of purple. S.3-6 in., shiningwhite, hollow. $R$. basal, evanescent. Gregarious, tufted, about old stumps and on rich soil in spr. and aut. Edible.

C. micaceus (mica, a glistening grain), "Glistening Inkcap." Plate XXXVII. 5.

P. $1 \frac{1}{2}-2 \frac{1}{2}$ in., coarsely striate, ochraceous-tan, disc darker; when young, glistening with particles of oxalate of lime, which in dry weather are permanent, and resemble mica in appearance. $G$. adnexed, lanceolate, whitish, then brown, 
finally black. S. 2-3 in., whitish, brittle, hollow. Densely tufted about old stumps; not appearing in win. Sometimes producing three crops in one year.

\section{ANELLARIA}

(Anellus, a little ring-from the ring on the stem)

A. separata (separatus, distinct-from its distinct characteristics). Plate XXXVII. I.

P. I-I $\frac{1}{2}$ in., ovate, then bell-shaped, never expanding, sticky, yellowish-white, shining, "wrinkled when old like washleather." G. thin, crowded, broad, greyish-black, margin paler. S. 3-5 in., straight, attenuated upwards. $R$. distant, persistent. Common; not appearing in win.

A. fimiputris (fimus, dung; putris, rotten-its habitat) is more slender and fragile than the above, and the ring is very imperfect. Common on dung in pastures.

\section{PANEOLUS}

(Gr. panaiolos, all variegated-from the variegated gills)

P. campanulatus (campamila, a little bell-bell-shaped). Plate XXXVII. 3.

P. $I \frac{1}{2}$ in. high and broad, bell-shaped, more or less umbonate, neither expanding nor splitting, glabrous brown, becoming reddish. $G$. adnate, crowded, ascending, grey, variegated with black. S. 3-5 in., straight, entirely reddish; often beaded with moisture in rainy weather; hollow. Veil exceedingly fugacious. Common on well-manured ground in sum. and aut.

P. papilionaceus (papilio; a butterfly-variegated), which affects similar situations, may be distinguished from the above by the hemispherical and much paler pileus, usually cracked into scales when dry, the paler stem, and the broader, broadly adnate gills. 


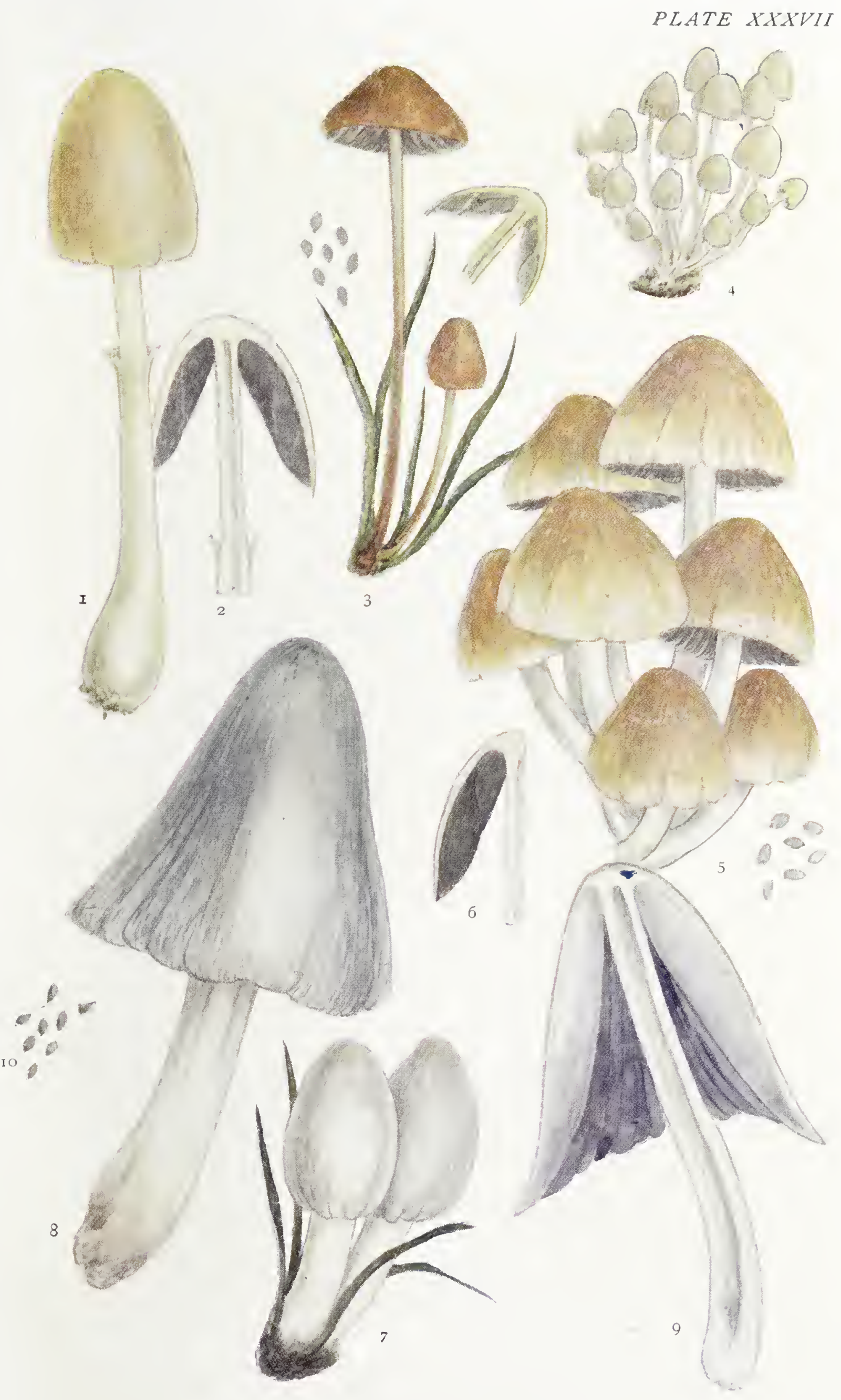

BLACK-SPORED AGARICS (MELANOSHORAE) 


\section{DESCRIPTION OF PLATE XXXVII}

\section{BLACK-SPORED AGARICS (MELANOSPORÆ)}

Fig. I.-Anellaria separata.

FIG. 2.-Ditto, section.

FIG. 3.-Pancoolus campanulatus, young and mature, with section and magnified spores.

FIG. 4.-Psathyrella disseminata, showing the cæspitose habit.

FIG. 5.-Coprimus micacens: group of plants and magnified spores.

FIG. 6.-.Ditto, section.

FIGs. 7-IO.-Coprinus atramentarius, young and mature, with section and magnified spores. 


\section{PSATHYRELLA}

(Diminutive of Psathyra, a genus of the Porphyrosporæ)

P. disseminata (dissemino, to scatter-widely spread). Plate XXXVII. 4.

$P$. $\frac{1}{2}$ in., ovate, bell-shaped, scurfy, striate, plicate, membranaceous; reddish-brown at first, then grey. G. adnate, distant, white, then blackish. S. I-2 in., somewhat curved, greyish, brittle, hollow. Forms dense tufts, sometimes more than a foot across, on old stumps, about posts, on walls, etc.; sometimes terrestrial. Very common, not appearing in win.

P. gracilis (gracilis, slender).

P. $\frac{2}{3}$-I in., submembranaceous; conical, then expanded; striate and brownish when moist; pale yellow or rose colour without striæ when dry. G. broadly adnate, rather distant, greyish-black; margin somewhat rosy. S. 3 in., straight, naked, pale, hollow. Common in hedges, etc., in late sum. and aut.

\section{GOMPHIDIUS}

(Gr. gomphos, a large nail or bolt-from the shape of the sporophore)

A very remarkable genus not closely allied to any other. It might with equal propriety be placed in any of the groups with coloured spores. The spores are fuscous or greenish, very large, elongated spindle-shape, resembling those of the Boleti. The entire fungus is tough and elastic. Fries considered Gomphidius, judging from its habit, to be intermediate between Cortinarius and Hygrophorus.

G. glutinosus (from the glutinous pileus), "Peg-top." Plate XLIII. I.

P. 2-5 in., margin long, incurved, purplish-brown or fulvous. $F$. thick except at the margin, white. $G$. more or less decurrent; whitish, then grey; greenish-olive at maturity. 
S. 2-4 in., stout, whitish, solid. F. white, yellowish at the base. $R$. indistinct. Common in aut. in pine woods. G.viscidus ("Rhubarb-stem") differs in the umbonate pileus and pale yellowish-brown flesh; the stem is rhubarb colour within and without. $G$. vosens may be known by the bright rose-red or dark crimson-red pileus.

\section{PORPHYROSPOR里}

Spores purple-black. Gills black or brown, with a purple tinge at maturity.

\section{PSATHYRA}

(Gr. psathuros, friable-from the friable substance)

P. corrugis ( $n u g a$, a wrinkle). Plate XXXVIII. 4.

$P$. I-2 in., submembranaceous, bell-shaped, umbonate, corrugated when dry, very pale ochre, often tinged with pink. G. sinuate, adnexed, broad, violet-black. S. 2-3 in., slender, equal, smooth, white, hollow. Frequent in pastures, appearing in April.

P. mastiger (Gr. mastos, the breast; gevo, I bear-from the breast-like shape), a common species amongst grass by roadsides, is easily distinguished by the mammiform umbo, and the rich brown colour when moist.

\section{PSILOCYBE}

(Gr. psilos, naked; kıbe, a head-from the naked pileus)

P. spadicea (spadicens, date-brown-the colour of the pileus). Plate XXXVIII. I.

P. I-3 in., plane at maturity, hygrophanous, bay-brown when moist, pallid when dry. $G$. adnexed, rounded behind, dry, crowded, pale at first, rosy-brown at maturity. Spores brown. S. 2-4 in., slender, equal, whitish, smooth, hollow. 

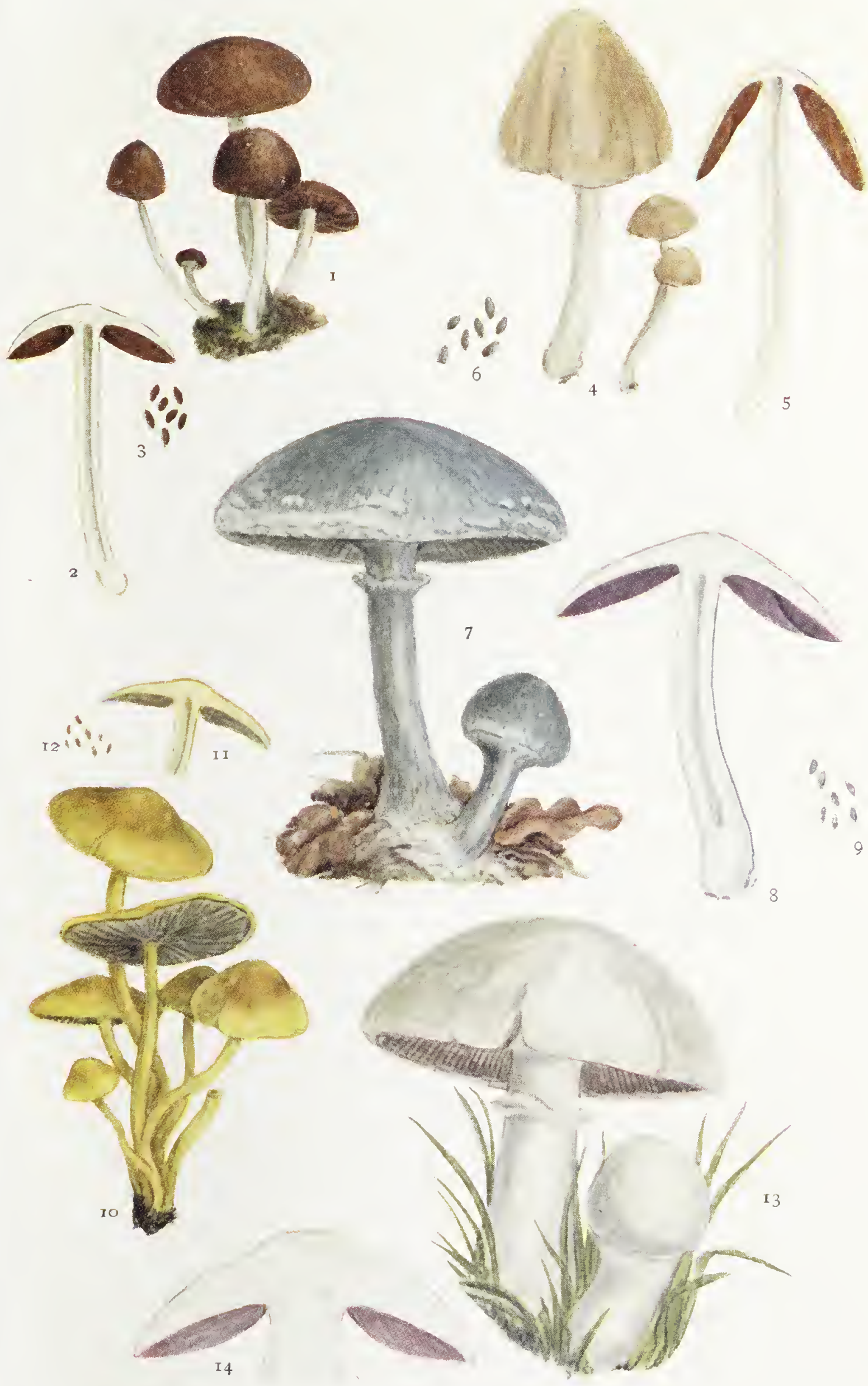

PURPLE-ISIACK SPORED AGARICS (PORHHYROSPORAE) 


\section{DESCRIPTION OF PLATE XXXVIII}

PURPLE BLACK-SPORED AGARICS (PORPHYROSPORÆ)

FIG. I.-Psilocybe spadecea, of various age.

Fig. 2.-Ditto: section showing the adnexed gills and hollow stem.

FIG. 3.-Ditto: spores highly magnified.

FIG. 4.-Psathyra corrugis, of various ages.

FIG. 5-Ditto: section showing the adnexed gills and hollow stem.

FIG. 6.-Ditto: spores, highly magnified.

Fig. 7.-Stropharia cemginosa, young and mature.

FIg. S.--Ditto, section.

FIG. 9.-Ditto: spores highlv marnified.

Fig. IO.- Hypholoma fascicularis.

FIG. II.-Ditto, section.

FIG. I2.-Ditto: spores highly magnified.

FIG. I3.-Agaricus arvensis: very young and smail mature plants.

FIG. I4.-Ditio: section showing the thick flesh of the pileus and the frice gills. 
In tufts amongst leaves, at the foot of stumps, etc., in sum. and aut. Very common. "Very distinct from Hypholoma appendiculatum, which it approaches in colour, in the more rigid pileus and stem, and in the complete absence of a veil. Known from every other species of the present genus in the gills being white, then flesh colour, and finally brown. In size and other points, very variable. Typically large, terrestrial, forming large loose clusters" (Fries).

P. fonisecii (fonisicia, hay harvest-occurring amongst grass in recently mown pastures). Plate IX. I.

$P . \frac{1}{2}-\mathrm{I}$ in., bell-shaped at first, then expanded; dingy brown, becoming pale; drying from the apex downwards. $G$. adnate, ventricose (hence appearing broadly emarginate), rather distant, umber-brown. S. 2-3 in., slender, rigid, fragile; reddish-brown, then paler; hollow. "Stem straight, or often a little flexuous; somewhat resembling, superficially, Pancoolus papilionacens, but much smaller, and differing in the umber gills and spores" (Massee). Common in fields and on lawns; not appearing in win.

P. semilanceata (semi, half; lancea, a spear-the pileus nearly spear-shaped in vertical section), "Little Spear," appears in aut. in troops in fields, etc. $P . \frac{1}{2}-\frac{3}{4}$ in., acutely conical, margin more or less persistently incurved, sticky when moist, very pale yellow or bluish-green when dry. $G$. broadly adnate, brown, then blackish-purple, margin paler. $S .2-3$ in. slender, tough, shining, pale, wavy. Easily recognised by the spear-shaped pileus.

\section{HYPHOLOMA}

(Gr. huphe, a web; loma, a fringe-from the fringe-like veil)

H. fasciculare (fasciculus, a small bundle), "Sulphur-tuft." Plate XXXVIII. Io.

$P$. I-2 in., conic, then expanded, thin, glabrous, tawny, margin yellow. $G$. adnate, very crowded, yellow, then 
greenish. S. 3-4 in., slender, fibrillose, yellow within and without, curved, more or less wavy, hollow. Taste intensely bitter. Poisonous. It has been recorded from Glyncorrwg collieries with stems $4 \mathrm{ft}$. long. "One of the common agarics, abounding at the base of young trees and gateposts in a state of decay, and similar situations. The dense clusters it forms are frequently composed of several hundred plants, and the stems, which accommodate themselves in length and direction to their situation, are so crowded and compressed at their base as to appear more or less united in bundles, whence the origin of the specific name" (Greville).

H. sublateritius (later, a brick-somewhat brick-coloured) is closely allied to the above, but is a larger ( $P$. 2-4 in.) and more showy plant, seldom so densely tufted, pileus brickred, stem stuffed

H. appendiculatus (appendicula, a small appendage), a very common species, forming dense tufts on stumps in sum. and ant.; somewhat resembles Psilocybe spadicea, but is more robust and rigid, and the veil is totally absent.

\section{S'TROPHARIA}

(Gr. strophos, a sword-belt-from a fancied resemblance in the ring)

S. æruginosa (arugo, verdigris), "Verdigris Agaric." Plate XXXVIII. 7.

$P$. 2-3 in., convex, then almost plane; somewhat umbonate; at first covered with a bluish-green gluten, which disappears, leaving it a pale straw colour. When growing in woods, the pileus is often ornamented with scattered white squamules. G. adnate, broad, not crowded, whitish, then brown, with a purple shade at maturity. $S$. about 3 in., squamulose and sticky below the distant ring, smooth above, greenish, hollow. Common throughout sum. and aut. on the ground, and on rotting wood in hedges, woods, and pastures. 
S. semi-globata (semi, half; globus, a ball-hemispherical). Plate IX. 9.

$P$. about I in., hemispherical, glutinous, pale yellow. $G$. adnate, very broad, greyish, clouded with black. S. 3-5 in., slender, viscid, hollow, yellowish. $R$. imperfect, soon stained with the purple-brown spores. Common in pastures, except in win., on dung of horses and oxen, solitary or gregarious.

S. stercoraria (stercus, dung) much resembles the above and affects similar situations, but is "usually larger, and distinguished more especially by the distinct pith in the stem, by the portion of the stem below the ring being at first flocculose, and by the much larger spores" (Massee).

\section{PILOSACE}

(Gr. pilos, felt; sakos, a garment-from the pelliculose pileus)

P. Algeriensis (first observed in Algeria).

$P .3 .4$ in., fleshy, snow-white. $G$. distant, free, very narrow, dark purple. S. 2-3 in., stout, solid, white. There is only one British record. It is probable that a form of Agaricus campestris was mistaken for it.

\section{AGARICUS}

(Psalliota of some authors)

(The origin of the term Agaricus is peculiar. It is said to be derived from Agaria, a region of Sarmatia, Poland. Psalliota from Gr. psalion, a ring-in reference to the very evident ring.)

A. campestris (campus, a plain or field), "The Common Mushroom." Plate IV. I.

P. 3-6 in., globose, then convex, dry, silky, whitish, the floccose epidermis projecting beyond the gills. $F$. thick, white, more or less stained with reddish-brown. $G$. free, 
very broad, pink, then flesh colour, blackish-brown at maturity. S. 3-4 in., stont, stuffed (elongated, bulbous, and hollow in the var. silvicola). $R$. median, thick, persistent. In rich pastures, particularly where salt has been strewn. Very variable. Var. pratensis, $P$. adorned with small rufous scales. Var. nufescens, $G$. at first quite white, very distinct in the bright-red flesh when bruised.

A. arvensis (arvum, a cultivated field), "Horse Mushroom." Plate XXXVIII. I3.

$P$. 4-I 8 in., white, stained yellow, flesh yellowish. G. free, broadest in front, whitish, then dark purplish-brown. $S .2 \cdot 5$ in., very stout, firm, soft in the centre, which is loose and thread-like. $R$. pendulous, double. Common in pastures (particularly where horses have been fed) in spr. and aut., often growing in large circles. Smell strong. Edible. The mushrooms cultivated by gardeners are said by W. G. Smith to be a variety of this species, not of $A$. campestris, as is usually supposed.

\section{CHITONIA}

(Gr. chiton, a tunic-from the veil enveloping the plant in infancy)

C. rubriceps (nuber, red; caput, the head-from the red pileus).

$P . \frac{2}{3}$-I in., umbonate, reddish-brown. $G$. free, narrow, crowded, purplish-brown. S. 3 in., slender, hollow, paler than the pileus. $V$. large, free, margin irregularly torn, whitish. An exotic species found on soil in the Aroid House, Kew Gardens. 


\section{OCHROSPOR\&}

Spores ochraceous, bright brown or bright rust colour. Gills dingy and ochraceous; brownish or reddish-brown at maturity; never with a purple tinge.

\section{PAXILLUS}

(Paxillus, a small stake or peg-from the form of the sporophore)

P. involutus (from the involute pileus). Plate XL. 7 .

P. 2-5 in., depressed in the centre, smooth when dry, yellowish-brown; the margin involute and hairy. $G$. more or less decurrent, yellow, darker when bruised; sometimes forming elongated pores at the base; occasionally wholly porous. S. I-2 $\frac{1}{2}$ in., thick, solid, firm, dull; yellow above, purplish below. In late sum. and aut. very common in woods and on old stumps. Sometimes attacked by a yellow mould, Hypomyces chrysospermus.

\section{CORTINARIUS}

(From the cortina, or veil)

A well-marked genus, containing a large number of autumnal, and with one exception, terrestrial species, possessing in common the following features: (I) A cobweblike veil ; (2) persistent dry gills, often violet or purplish, at first becoming ferruginous or bright cinnamon at maturity ; (3) bright rust-coloured spores. For the most part, frequenting woods and amongst grass under trees in fields. 
There are six well-defined sub-genera:

\begin{tabular}{|c|c|c|c|c|}
\hline Sub.genus. & Pileus. & Flesh. & Veil. & Stem. \\
\hline I. Phlegmacium & Glutinous & Thick, equal & Partial, cob- & Firm and dry \\
\hline 2. Myxacium & Glutinous & Rather thin & Universal, glu- & Glutinous \\
\hline 3. Inoloma & Dry, usually & Thick, equal & Simple & Fleshy, some- \\
\hline 4. Dermocybe & $\begin{array}{l}\text { Dry, silky, gla- } \\
\text { brous when } \\
\text { adult }\end{array}$ & $\begin{array}{l}\text { Thin, equal, } \\
\text { watery when } \\
\text { moist }\end{array}$ & $\begin{array}{l}\text { Simple, fibril. } \\
\text { lose }\end{array}$ & $\begin{array}{l}\text { Equal or at- } \\
\text { tenuated }\end{array}$ \\
\hline 5. Telamonia & $\begin{array}{l}\text { Hygrophanous, } \\
\text { moist }\end{array}$ & $\begin{array}{l}\text { Equally thin, or } \\
\text { abruptly thin } \\
\text { towards the }\end{array}$ & $\begin{array}{l}\text { Universal } \\
\text { double }\end{array}$ & $\begin{array}{c}\text { Annulate, or } \\
\text { peron ately } \\
\text { scaly below }\end{array}$ \\
\hline 6. Hydrocybe & $\begin{array}{l}\text { Moist, not glu- } \\
\text { tinous, pale } \\
\text { when dry }\end{array}$ & Very thin & Thin, fibrillose & $\begin{array}{l}\text { Rather rigid, } \\
\text { not peronate }\end{array}$ \\
\hline
\end{tabular}

\section{SUB-GENUS I.-PHLEGMACIUM}

(Gr. phlegma, shining moisture-from the clammy pileus)

Cortinarius (Phlegmacium) calachrous (Gr. kalos, beautiful ; chros, colour-from its beautiful colours). Plate XXXIX. 9.

P. 2-3 in., convex, then plane, obtuse, viscid, tawny, yellowish towards the margin, which is involute at first. $G$. emarginate, crowded, dark purple with serrate margin. S. $I_{\frac{1}{2}}-2$ in., thick, with a very distinct emarginate bulb, yellowish (never a trace of blue). Veil yellow, fugacious. In woods (especially beech) and pastures. Frequent.

Cortinarius (Phlegmacium) purpurasceus (from the gills becoming purple when bruised).

P. 4-5 in., wavy, covered at first with thick gluten, then dry; reddish-bay or tawny-orchraceous, spotted; margin incurved at first, marked with a raised brown line. $F$. clear blue. $G$. broadly emarginate, crowded, bluish tan at first, cinnamon at maturity. S. 3 in., very stout, solid, bulbous, clear blue. Both stem and gills become spotted violet purple when touched. Common in pine and mixed woods.

Cortinarius cærulesceus (ccomlens, azure-from the azure- 


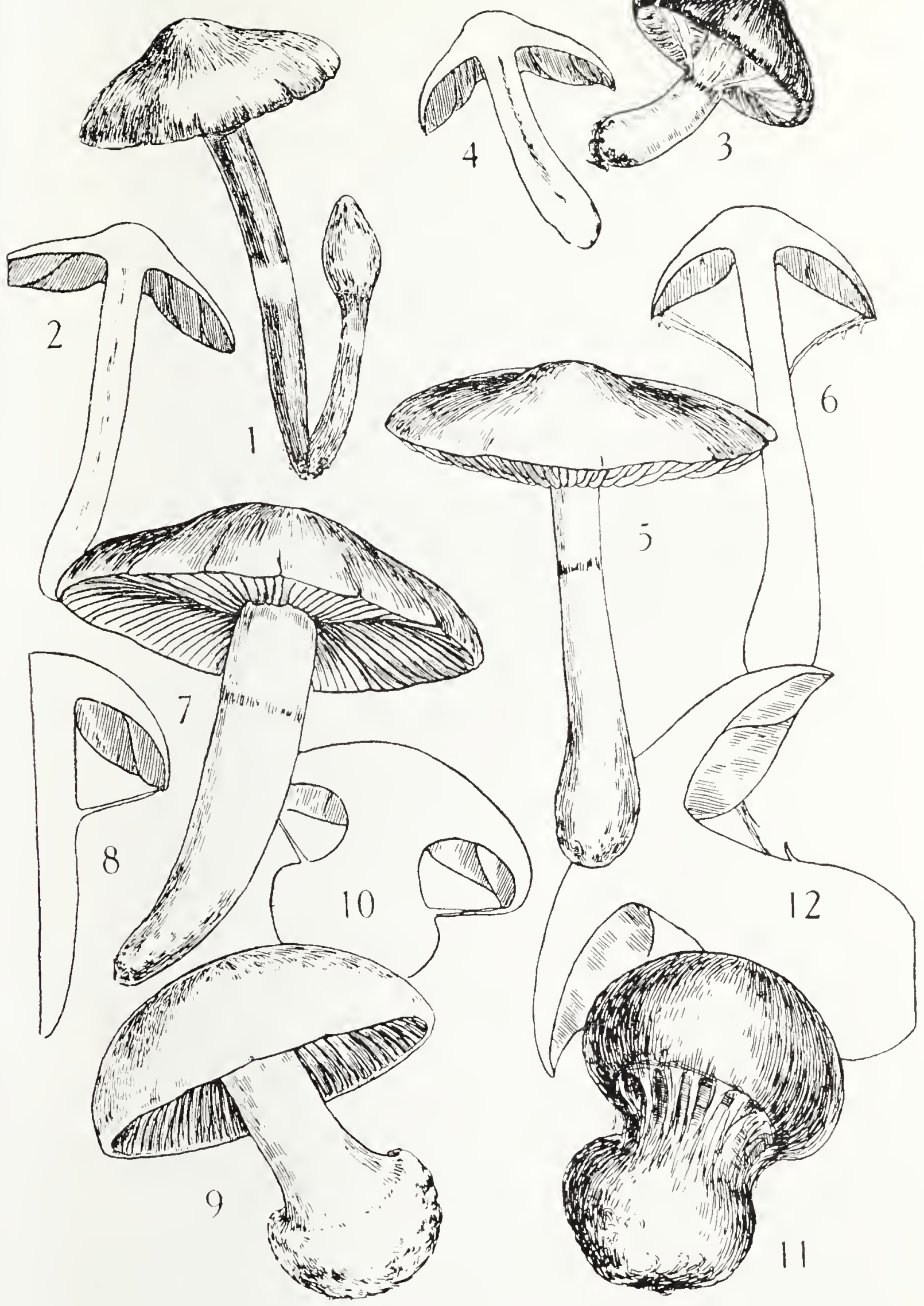




\section{DESCRIPTION OF PLA'TE XXXIX}

AGARICS WITH RUST-COLOURED SPORES (GENUS CORTINARIUS)

FIG. I. - C. (Telamonia) himmlens, young and mature.

FIG. 2.-Ditto: section showing the broad emargınate gills.

Fig. 3. - C. (Hydrocybe) casluneus.

FIG. 4.-Ditto: section showing the broad, slightly emarginate gills.

Fig. 5.-C. (Dermocybi) caninus, mature.

FIG. 6.-Ditto: section of young plant.

FIG. 7.-C. (Myracium) elutior, mature.

FIG. 8.-Ditto: section of young plant.

FIG. 9.-C. (Phlegmacium) culochrous, mature.

FIG. IO.--Ditto: section of young plant showing the invol te margin, and stem with abruptly marginate bulb.

FIG. II.-C. (Inoloma) violaceus, young, showing the wool veil

FIG. I2.--Ditto: section of mature plant showing the ver; ,road gills 
clouded pileus) differs from the above in not changing colour when broken; entirely blue when young.

\section{SUB-GENUS 2.-MYXACIUM}

(Gr. muxa, mucus-from the glutinous pileus and stem)

Cortinarius (Myxacium) elatior (elatus, tall). Plate XXXIX. 7 .

P. 3-4 in., wrinkled, yellowish- or brownish - black. $G$. adnate, veined, brown-cinnamon. S. 6 in., greyish or purplish, attenuated downwards, sometimes bearing a fugitive viscid veil. Common in mixed woods, pine and beech.

Cortinarius (Myxacium) collinitus (collino, to besmear-the pileus smeared with gluten), "Glue-cap."

$P .3-5$ in., convex, with incurved margin; then expanded, obtuse, shining, glutinous, tawny-orange. $G$. adnate, tan colour, then cinnamon. S. 3-5 in., firm, equal, transversely scaly from the breaking-up of the glutinous veil; bluish or white. The var. mucosus is a firmer plant, with an even silky stem (in pine woods). Common in late sum. and aut. in woods and amongst heather.

Cortinarius (Myxacium) mucifluus (flowing with mucus) differs from the preceding in the white stem, attenuated downwards, and the reflexed, yellowish, wavy pileus, with striate margin, covered at first with a thin colourless gluten. There is no trace of violet anywhere. Abundant in heathy pine woods on sandy soils.

\section{SUb-GENUS 3.-INOLOMA}

(Gr. is, inos, a fibre; loma, a fringe-from the fringed veil)

Cortinarius (Inoloma) violaceus (from the violet colour), "Imperial." Plate XXXIX. I I.

P. 3-6 in., covered with persistent down, margin at first incurved, dark-violet within and without. G. adnate, dis- 
tant; dark violet at first, cinnamon when the spores are formed, again violet when they have fallen. S. 3-4 in., stout, very bulbous, soft, dark violet (greyish-violet within). Veil woolly, blue, becoming rusty from the falling spores. Frequent in open places in woods and on their borders. A very handsome agaric, abundantly distinct from other violet species (Tricholoma mudum, etc.) in the white cobwebby veil and rusty spores. A good esculent, resembling Agaricus campestris in flavour. Inoloma Bulliardi has a vermillion bulb. I. bolavis (bolave, to mark) has the light yellowish-red pileus marked with sienna-red scales. Both occur in beech woods. I. pholideus (Gr. pholis, a scale), an inhabitant of mixed woods, may be recognised by the fawn-coloured pileus and stem, clad with erect, dark, umber scales.

\section{SUb-Genus 4.-DERMOCYBE}

(Gr. derma, skin; kube, a head-from the thinly, fleshy pileus)

Cortinarius (Dermocybe) caninus (canis, a dog-from its frequency), "Brown Dog." Plate XXXIX. 5.

P. 3-4 in., convex, thin, flattened, bricl-red or brown. $G$. emarginate, grey or purplish, cinnamon at maturity. S. 3-4 in., somewhat bulbous, whitish, apex violet, stuffed, then hollow. Allied to $C$. tabularis, which differs in size; also to $C$. anomalus, the latter, however, differs in the peronate and somewhat ringed stem, and the fuscous or rufescent pileus. Very common in mixed woods.

Cortinarius (Dermocybe) tabularis (tabula, a flat boardfrom the flat pileus).

$P \cdot 3-4$ in., convexo-plane, remarkably flattened at maturity, tan colour, becoming paler. $G$. slightly emarginate, crowded, thin, white, then tan colour. S. 2-3 in., slender, tough, pallid, becoming hollow. Veil white, fugacious. Common in woods. Larger, paler, and more glabrous than C. ano- 
malous, in which the gibbous or subumbonate pileus seldom exceeds 2 in. diam.

Cortinarius (Dermocybe) cinnamomeus (from the cinnamon colour), "Cinnamon-cap." Plate XI. I.

P. I - $2 \frac{1}{2}$ in., convexo-campanulate becoming nearly plane, obtusely umbonate, silky with yellowish down, usually bright cinnamon. $G$. adnate, broad, crowded, thin, always shining, margin often notched, yellowish, then tawny-yellow. S. 2-4 in., slender, equal, hollow, yellow within and without, common in mixed woods and fir plantations in aut. and early win.

In the var. semi-sanguineus, the gills are narrow with a beautiful blood-red tint, or orange-brown with a red tinge.

Cortinarius (Dermocybe) sanguineus, "Blood-red agaric," a small species ( $P$. I-2 in.) frequent in woods, chiefly pine, in aut. is entirely blood-red within and without, and the stem ( $1 \frac{1}{2}-2$ in.) gives out a blood-red juice when squeezed.

\section{SUb-GENUS 5.-TELAMONIA}

(Gr. telamon, lint-from the lint-like fibres of the veil)

Cortinarius (Telamonia) hinnuleus (from its fawn colour). Plate XXXIX. I.

P. I-3 in., conico-campanulate, expanded at maturity, glabrous, tawny cinnamon, pallid when dry. $G$. slightly emarginate, distant, tawny cinnamon. S. 3-4 in., attenuated below, tawny, stuffed; veil whitish, silky, forming a ringlike zone. Common in mixed woods in aut.

Cortinarius (Telamonia) armillatus (armilla, a ring-from the zones on the stem).

P. 3-4 in., brick-red, pale when dry. G. adnate, distant, pale, then dark cinnamon. S. 4-5 in., somewhat bulbous, solid, pale, girt with several oblique red rings. Frequent in mixed woods under hazel. 
Cortinarius (Telamonia) hæmatochelis (Gr. haima, blood; chelus, the chest-from the blood-red ring on the stem) differs from the preceding in the single red zone on the stem. In beech woods. In both the vermillion zone (or zones) is permanent after drying:

\section{SUb.GENUS 6.-HYDROCYBE}

(Gr. Iudov, water; kube, head-from the moist or hygrophanous pileus)

Cortinarius (Hydrocybe) castaneus (castanea, a chestnutfrom its colour), "Chestnut-cap." Plate XXXIX. 3.

$P$. up to 2 in., campanulate, then expanded, with a more or less obtuse umbo, glabrous, brownish-chestnut, the umbo becoming blackish. $G$. adnate, at first purplish umber, then ferruginous. S. I-I $\frac{1}{2}$ in., slender, almost equal, pale red or tinged violet, imperfectly hollow. Veil scanty, white, fibrillose. Gregarious in woods, pastures, and gardens. Common in late sum. and aut. Sometimes growing on wood; in this feature it is unique amongst species of Cortinarius.

Cortinarius (Hydrocybe) obtusus (from the obtuse and disappearing umbo).

P. $\frac{1}{2}$-I $\frac{1}{2}$ in., conical, then campanulate, obtusely umbonate, glabrous, margin striate, rusty-bay at first, then cinnamon, whitish-tan when dry. $G$. adnate, somewhat distant, very broad, connected by veins, ferruginous, then tawny-cinnamon. S. 2-4 in., slender, curved, attenuated below, fragile, yellowish-tan, white when dry. A strong-smelling species occurring in troops in pine woods in aut. and aut.

Cortinarius (Hydrocybe) acutus, a scattered or gregarious species ( $P . \frac{1}{2}-\frac{2}{3}$ in., S. 3-4 in.), frequent in mixed woods, yellowish - honey colour, is remarkable in the acute umbo. 


\section{DESCRIPTION OF PLATE XL \\ BROWN-SPORED AGARICS (OCHROSPORA)-I}

FIG. I.-Cortinarius (Dermocybe) cimnamomens: plants of various ages, with section and magnified spores.

FIG. 2.-Bolbitius fragilis: plants of various ages, with section and magnified spores.

FIG. 3.-Pholiota squarrosa: plants of various ages, showing the scaly pileus and stem and the large ring.

FIG. 4.-Ditto: section showing the thick yellowish flesh.

FIG. 5.-Hebeloma crustiliniformis and magnified spores.

FIG. 6.-Ditto: section showing the thick flesh discoloured below the disc.

FIG. 7.-Paxillus involutus.

FIG. 8.-Ditto: section showing the incurved margin.

FIG. 9.-Inocybe rimosa, with section and spores.

FIG. Io.-Crepidotus mollis: imbricated pilei on rotting wood.

FIG. I I.-Ditto, showing the gills radiating from the short stem.

FIG. I2. - Section showing the decurrent gills. 


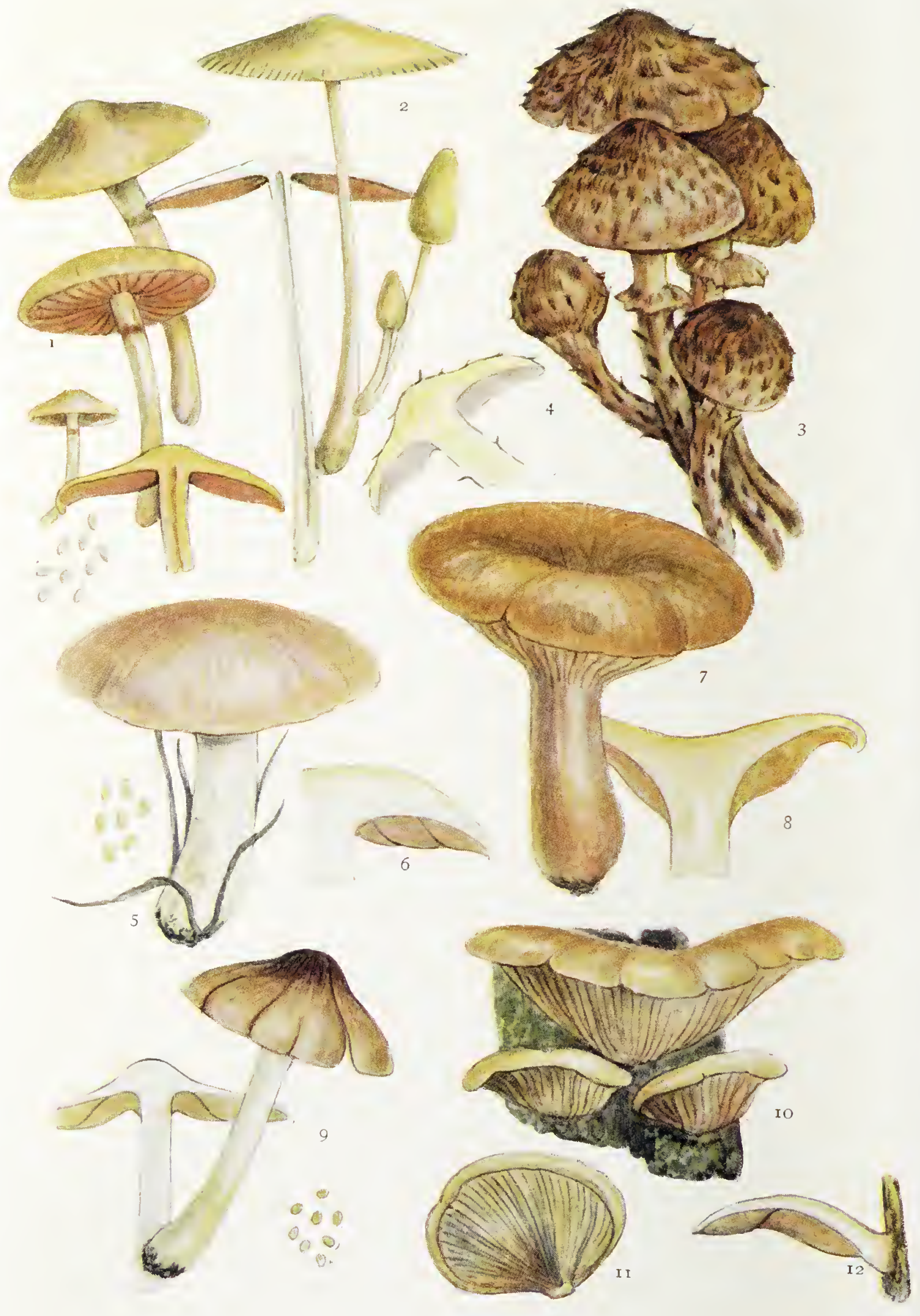

BROWN-SPORED AGARICS ( 


\section{CREPIDOTUS}

(Gr. krepis, a slipper-from the shape of some species)

C. mollis (mollis, soft), "Soft Slipper." Plate XL. Io.

P. I-3 in., soft, somewhat gelatinous, subsessile, pale dingy tan or greyish, often stained with the rusty spores when growing in an imbricated manner. $G$ : crowded, radiating from the point of attachment, whitish at first, then watery cinnamon. Common on old stumps, especially ash; not appearing in win.

C. rubi (nubus, bramble) is gregarious on bramble-stems. Uncommon:

C. epibryus (Gr. epi, upon; brnon, moss) grows on mosses, etc. White, diam. $P \cdot \frac{3}{10}$ in.

\section{TUBARIA}

( $T u b a$, a trumpet-from the shape of typical species)

T. furfuracea (furfur, bran-from the scurfy pileus). Plate XLI. I.

$P . \frac{1}{3}-2$ in., convex, then plane, at length depressed, hygrophanous, yellowish-cinnamon, minutely furfuraceous. $G$. adnato-decurrent, rather distant, cinnamon. $S$. I-2 in., slender, hollow, paler than the pileus, with white down at the base. On twigs, branches, chips, etc.; common throughout the year.

\section{FLAMMULA}

(Flamma, a flame-from the flame-like colours of many species)

F. carbonaria (carbo, charcoal-from its habitat), "Carbon Agaric." Plate XLI. Io.

P. I-3 in., convex, then plane, viscid, margin inflexed tawny-yellow. $F$. yellow. $G$. adnate, crowded, brownish 
clay colour. S. I $\frac{1}{2}-3$ in., slender, minutely scaly, imperfectly hollow, pale, darker below. Spore mass ferruginous brown. Gregarious on burnt earth, charcoal, etc., in and about woods, frequent in aut. The uncommon $F$. spumosa (spuma, froth-from the frothy, viscid pileus) much resembles the preceding, but is at once known by the yellow-brown (never ferruginous) spore mass.

\section{GALERA}

(Galevis, a cup-from the shape of the pileus)

G. tenera (tener, tender), "Tender-cup." Plate XLI. 8.

$P . \frac{1}{2}-\frac{3}{4}$ in., conico-campanulate, entirely pale ferruginous when moist, pale when dry. G. adnate, crowded, rather broad, cinnamon. S. 3-4 in., thin, equal, striate above, the colour of the pileus. A variable species, common amongst grass in pastures, woods, and gardens, sum. and aut.

G. hypnorum (hypnum, a genus of moss), "Moss-cup." Plate XLI. 5 .

P. $\frac{1}{4}-\frac{3}{4}$ in., membranaceous, bell-shaped, often with a papillate umbo, finely striated up to the disc, yellowishochre when moist, tan colour when dry. G. adnate, broad, distant, usually connected by veins, tawny-cinnamon. $S$. about 2 in., flexuous, slender, hollow, tawny or ochraceous. A little slender species with a very strong alkaline smell, common in sum. and ant. amongst moss. The variety sphagnonum, which may be found amongst sphagnum moss in bogs, is about three times the size of the type, with longer and firmer stem (Plate XLI. 7).

\section{NAUCORIA}

(Naucum, a trifle-from the almost obsolete veil)

N. melinoides (Gr. mel, honey ; eidos, appearance). Plate XLI. 3 . 


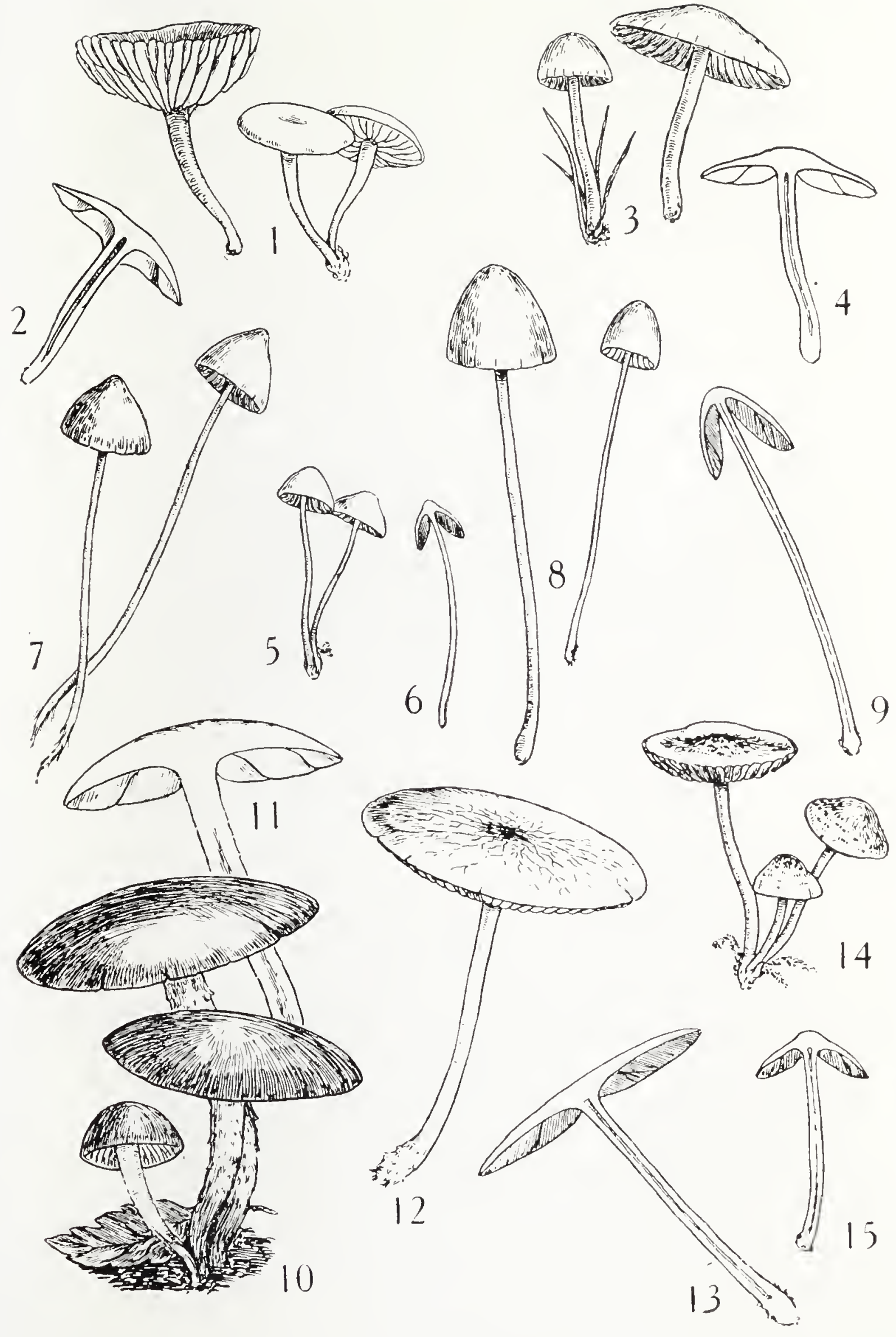




\section{DESCRIPTION OF PLATE XLI \\ BROWN-SPORED AGARICS (OCHROSPORÆ)-II}

FIG. I.-Tubaria furfuracea: plants of various ages.

Fig. 2.-Ditto: section of mature plant showing the adnatodecurrent gills.

FIG. 3.-Nancoria melinoides, young and mature.

FIG. 4.-Ditto, section.

FIG. 5.-Galera hypnonum.

FIG. 6.-Ditto, section.

FIG. 7.-Ditto, var. sphagnormm, two plants.

Fig. 8.-Galera teneva, young and mature.

FIG. 9.-Ditto, section.

FIG. Io.-Flammula carbonaria: plants of various ages.

FIG. II.-Ditto, section.

Fig. I2.-Fluteolus veticulatus.

FIG. I3.-Ditto: section.

Fig. I4.-Nancoria escharoides: plants of various ages.

Fir. 15.-Ditto, section.

(All two-thirds natural size.) 
P. $\frac{1}{2}-$ I in., convex, then plane, glabrous, tawny, then ochraceous, striate at the margin when old. $G$. adnate, crowded, minutely toothed, honey colour. S. I-2 in., hollow, colour of the pileus, paler at the base, and sprinkled with white meal at the apex. A little variable species commonly seen on lawns in sum. and aut.

N. cucumis (from its odour of cucumber). $P .2 \frac{1}{4}$ in., chestnut-umber; frequent in woods and grassy places, and also on wood; is remarkable in the strong penetrating smell of cucumber, or of rotten fish.

$N$. escharoides ( $\mathrm{Gr}$. eschava, a scar; eidos, appearance). Plate XLI. I4.

P. $\frac{1}{2}-\frac{2}{3}$ in., conico-convex, then expanded, scurfy, tan colour, disc becoming brownish. $G$. adnexed with a decurrent tooth, at length emarginate, broad, pallid tan, then approaching cinnamon. S. I- $2 \frac{1}{2}$ in., slender, fragile, hollow, pallid, then fuscous. Gregarious, frequent on naked ground under alders. Dingy brown and insignificant, but easily known by its habitat.

\section{HEBELOMA}

(Gr. hebe, youth ; loma, fringe-in allusion to the fringe-like veil of some species)

H. crustuliniforme (crustulum, a small pie-the shape of the pileus), "Poison-pie." Plate XL. 5.

P. $2 \frac{1}{2}-3 \frac{1}{2}$ in., convex, then plane, obtuse or slightly umbonate, slightly viscid at first, zoneless, pallid tan colour, disc yellowish or brick-red. $G$. adnexed, rounded behind, crowded, narrow, thin, bay, exuding drops of water in wet weather. S. 2 in., stout, hollow, somewhat bulbous, white. Common in meadow and woods in aut., sometimes forming large rings. Said to be often mistaken for the "Horse Mushroom." Poisonous. Smell strong, like radishes or laurel flowers. H. fastibile differs in the more distant gills 
and the evident veil which sometimes forms a ring round the stem. It is also mistaken, not infrequently, for the "Horse Mushroom."

\section{INOCYBE}

(Gr. is, inos, a fibre; kube, a head-from the fibrous pileus)

I. rimosa (vima, a crack-from the cracked pileus). Plate XL. 9 .

$P$. I-2 in., bell-shaped, very slightly umbonate, cuticle splitting longitudinally, yellowish-brown. G. almost free, rather crowded, pale dingy tan colour. S. 2-3 in., slender, solid, firm, smooth, whitish, mealy above. Subgregarious in woods; sum. and aut. common. I. asterospora (aster, a star) differs chiefly in the coarsely-warted spores; I. entheles (Gr. eu, well; thele, a teat), in the distinct umbo, adnate gills, and in growing under firs. I. pyriodora (pyrus, a pear) is somewhat stouter, and has a strong pear-like smell.

I. geophylla (Gr. ge, the earth; phullon, a leaf-from the earthy colour of the gills).

$P . \frac{1}{2}$-I in., conical, then expanded, umbonate, dry, silky, cuticle, breaking up into silky fibrils, white, lilac, or violet; white or yellowish when old. G. almost free, crowded, white at first, then brown. S. 2-3 in., stuffed, glabrous, white or coloured like the pileus, apex with white meal. Gregarious, late sum. and aut. common amongst grass in woods.

\section{BOLBITIUS}

(Gr. bolbitow, cow-dung-a frequent habitat)

B. fragilis (from its fragility). Plate XL. 2.

$P$. about I in., viscid, almost membranaceous, pellucid, margin striate, rather umbonate, yellowish. $G$. adnexed, rather distant, yellowish, pale cinnamon at maturity. 
S. 2-3 in., slender, attenuated upwards, straight, hollow, yellow. Solitary, or in twos and threes. On dung and amongst grass in sum. and aut. Common.

B. titubans (titubans, shaking-from its tottering habit), "The Shaker."

$P$. up to I in., membranaceous, plicate, pale yellow, deeper in the centre. $G$. slightly adnexed, distant, pale, then salmon colour. S. $2-4$ in., slender, shining, straight, hollow, yellowish. An elegant, fragile little species, common amongst grass, near rotten stumps, etc., in sum. and aut.

\section{PLUTEOLUS}

(Diminutive of Pluteus, a genus of the Rhodosporæ)

P. reticulatus (from the network of veins on the pileus). Plate XLI. I2.

$P$. I-I $\frac{1}{2}$ in., bell-shaped, then plane, viscid, surface vaguely veined, margin striate, greyish-lilac. $G$. free, crowded, rusty saffron. S. I $\frac{1}{2}-2$ in., slender, fragile, hollow, white. Spore mass ferruginous. On dead wood. Rare.

\section{PHOLIOTA}

(Gr. pholis, a scale-from the scaly pileus)

P. squarrosa (squarrosus, rough-from the scaly pileus). Plate XL. 3.

P. 2-4 in., fleshy, dry, reddish-yellow, covered with darker, erect, revolute hairs, collected in the form of scales. $G$. slightly decurrent, crowded, pale olive, then ferruginous. $S$. 3-6 in., stout, attenuated below, ascending, pale tawnybrown, covered with darker recurved scales, stuffed. $R$. brown, ragged; the stem is smooth above it. Usually strong smelling, like rank cheese. Common on trunks of various trees and on stumps, except in win., in large dense tufts. 
P. subsquarrosa resembles the above, but the gills are almost free.

P. spectabilis (spectabilis, notable).

$P$. 3-5 in., dry, bright tawny-orange, torn into innate similarly-coloured scales. $F$. firm, sulphur-yellow. $G$.adnato-decurrent, crowded, narrow ; pure yellow at first, then ferruginous. $S: 3-4$ in., thick, ventricose below the middle, and ending in a fusiform rooting base; sulphur colour, squamulose, even and mealy above the ample, spreading, persistent $R$. Tufted, on stumps. Frequent.

$P$. adiposa (from the pileus, as if covered with fat). Plate XIII. 4.

P. 2-4 in., fleshy, convex, glutinous; yellow, with concentric, squarrose, darker scales. F. whitish. $G$. adnate, yellow, then ferruginous. S. 3-6 in., thick, subequal, somewhat bulbous; coloured and marked like the pileus up to the floccose, radiating yellow $R$. Frequent on trunks of various trees in aut. A very showy species, at once distinguished by the glutinous pileus and stem. The rustcoloured scales which adorn them apparently dissolve away in the gluten.

P. mutabilis (mntabilis, changeable). Also forms dense tufts on trunks (chiefly lime and ash). Pileus not scaly, obtusely umbonate, deep cinnamon, pale when dry. Tastes like gingerbread.

\section{ACETABULARIA}

(Acetabulum, a vinegar cup-from the cup-like volva)

\section{A. acetabulosa.}

$P$. just over I in., white, plicate, tan colour. G.adnexed, subdistant, pale brown. S. 2 in., slender, hollow, white. $V$. small, whitish. An obscure plant found a little above high-water mark near Millbank, Westminster, in May, I795. Since then it has not been noted. "This is very 


\section{DESCRIPTION OF PLATE XLII}

\section{PINK-SPORED AGARICS (RHODOSPORÆ)}

FIG. I.-Eccilia rhodocylix. (Natural size.)

FIG. 2.-Ditto: section showing the broad decurrent gills.

FIGS. 3 and 4.-Leptonia lampropoda, young and mature.

FIG. 5.-Ditto: section showing the seceded gills.

Figs. 6 and 7.-Volvaria farvula, young and mature. (Natural size.)

FIG. 8.-Entoloma costatum.

FIG. 9.-Ditto: section showing the veined gills.

Fig. Io.-Nolanea pascua.

FIG. II.-Ditto: section showing the almost free gills.

FIG. I2.-Ditto: the nodulose spores. (Highly magnified.)

Figs. 13 and I4-Clitopilus prumulus, young and mature.

FIG. I5-Ditto: section showing the decurrent gills.

FIG. I6.-Ditto: the elliptical smooth spores. (Highly magnified.)

FIG. I7.-Entoloma nidnrosum, young and adult.

FIG. I 8.-Ditto: section showing the emarginate and almost free gills.

FIG. I9.-Plutelis cervinus.

EIG. 20.--Ditto: section showing the free broad gills. 


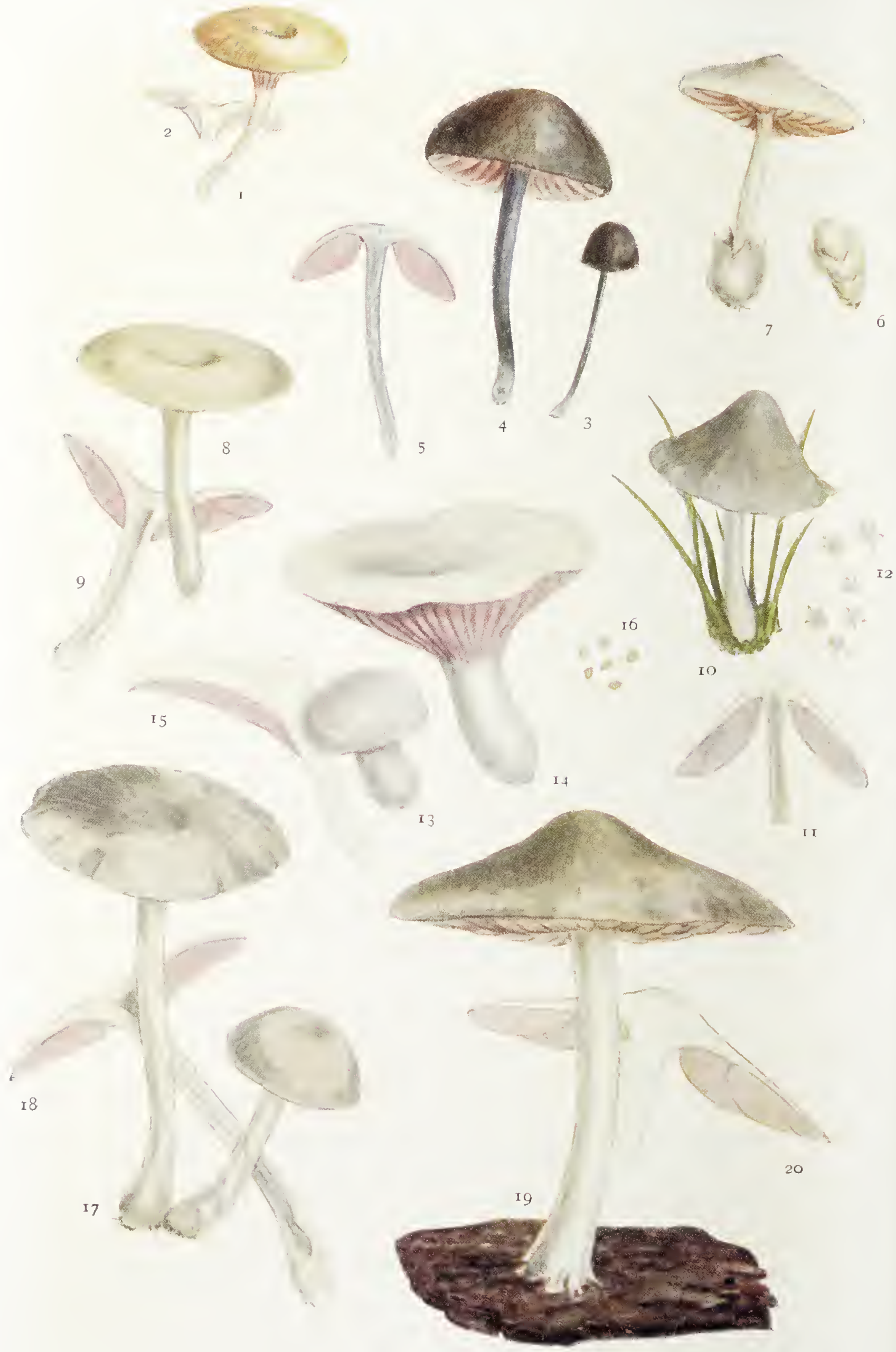

PINK-SPORED AGARICS (RHODOSPORAE) 
like a poor specimen of Agaricus congregatus (Coprinus micacens), but the pileus is not plicate. The lamellæ are remarkably glandular on their sides, and instead of a bare base, or foot, it stands in a little socket-like volva" (Sowerby). Boudier, the eminent French mycologist, associates it with Pluteus semibulbosus.

\section{RHODOSPORÆ}

Spores salmon colour or pink. Gills salmon colour or rosy at maturity. In some species the colour of the gills is very pale. These might easily be mistaken for certain members of the Leucosporæ, if the colour of the spore mass is not carefully noted.

\section{CLAUDOPUS}

(Clandus, lame, Gr. pous, a foot-from the dwarfed stem)

C. variabilis (from its variability). Plate XXXV. I.

$P$. up to I in. At first resupinate, attached by a more or less stem-like base, margin incurved and very thin, almost fleshless. Pure white, downy and delicate. G. narrow, radiating from the point of attachment; rather distant. White at first, becoming pale salmon colour. They remain white for some time, and the plant might then be mistaken for a Pleurotus. Common in ant. on dead wood, branches, moss, etc.

\section{ECCILIA}

(Gr. ekkoiloo, to hollow out-from the depressed pileus)

E. rhodocylix (Gr. vhodon, a rose; kulix, a cup-the pileus resembling a rose-coloured cup), "Rose-cup." Plate XLII. I.

$P$. about $\frac{1}{2}$ in., very thin, deeply umbilicate, margin reflexed; hygrophanous, brownish, grey when dry. G. broad, distant, deeply decurrent; whitish, then flesh colour. 9-2 
S. x in., very slender, cartilaginous, stuffed, glabrous, grey. On rotten trunlss, old walls, etc., in Sept. Corresponds in form and size with Omphalia umbellifera, and might be mistaken for it in the young state, when the gills are white.

\section{CLITOPILUS}

(Gr. klitos, a declivity; pilos, a cap-from the decurrent hymenophore)

C. prunulus (from the pruinose appearance of the pileus). Plate XLII. I3.

P. 2-4 in., wavy, very fleshy ; "white, shining, or opaque, with a slight tendency to cinereous; smooth, but under a lens minutely, though densely, tomentose, so that the impression of a finger is left upon it; margin involute" (Berkeley). G. very decurrent, slightly crowded, white; then flesh colour. S. I-I $\frac{1}{2}$ in., thick, often striate, white, base downy. Smell resembling new meal. A common species in woods and open pastures in sum. and aut. Edible.

C. orcella (ovgella, like an ear), allied to the preceding species, is smaller, less fleshy; stem more excentric, shorter, and grows in more open places. Worthington Smith observes that these species are not eaten by insects.

\section{LEPTONIA}

(Gr. lepos, slender-from the slender growth)

L. lampropoda (Gr. lampros, shining; pous, a foot), "Bluefoot." Plate XLII. 3 .

P. I-I $\frac{1}{2}$ in., mouse colour or bluish-grey, never striate. $G$. adnate, seceding, and becoming almost free, whitish, then rosy. $S$. I-I $\frac{1}{2}$ in., rather thick, glabrous, cartilaginous, hollow, bluish-violet. Common amongst grass in late sum. and aut. 
L. chalybea (Gr. chalups, steel - from its steel-blue colour).

$P$. brownish-slate or dark violet. G. bluish-grey, salmon or purplish. $S$. stuffed, colour of pileus. Gregarious in grass in pastures in late sum. and aut.

L. incana (incamus, hoary). P. striate, bronzy-green. $G$. adnexed. Gregarious in open fields and woods sum. and aut. Has a strong mouse-like odour. Frequent.

\section{NOLANEA}

(Nola, a little bell-from the supposed resemblance of the pileus to a little bell)

N. pascua (from its habitat, pastures), "Pasture Bell." Plate XLII. Iо.

$P$. conical, $\frac{2}{3}-\mathrm{I}$ in. high, then expanded, and $\mathrm{I}$ in. diam.; brown, becoming ochreous-brown; silky and shining when dry. G. somewhat crowded, almost free, salmon colour, margin eroded. S. I-2 in., fragile, distinctly fibrous, shining, slender, and pale. Sum. and aut. Common in pastures and open woods.

N. pisciodora (piscis, a fish; odor, a smell). P. dark brown. G. adnexed. Frequent amongst decaying leaves and sticks in woods; smell strong, like rotten fish.

\section{ENTOLOMA}

(Gr. ontos, within; loma, a fringe-from the potential veil)

E. costatum (costa, a rib-from the veined gills). Plate XLII. 8.

P. 2-3 in., convex, then almost plane, wavy, hygrophanous, livid-brownish, shining when dry. $G$. almost free, very broad, with raised veins or ribs extending from the base to the margin, pallid, then flesh colour. S. $2-2 \frac{1}{2}$ in., 
thick, somewhat striate, white, hollow. Usually in large tufts in damp meadows in ant.

E. sericeum (seviceus, silky) differs in the strong smell of new meal and the absence of veins on the gills.

E. clypeatum (clypers, a shield-from the shape of the pileus), "The Shield."

P. 2-3 in., bell-shaped, then expanded and umbonate, glabrous, lurid-grey. $C$. slightly adnexed, becoming free, rather distant, dingy, powdered red with the spores at maturity; margin serratulate, markedly so behind. $S$. 3-4 in., entirely fibrous, stuffed, then hollow, fragile, grey, powdery at the apex. Spv. and aut., frequent in woods and pastures.

E. nidorosum (nidov, reeking-from its strong smell). Plate XLII. I7.

P. 2-3 in., flesh thin, very fragile, glabrous but silky, shining when dry, greyish-fawn, then livid. G. emarginate, almost free, pallid, then pale flesh colour. S. 2-3 in., thick, almost solid, equal, whitish. In woods and on lawns; common in aut. A fragile species, with a strong allaline smell.

\section{PLUTEUS}

(Pluteus, a turret, or sentry-box-from a supposed resem. blance of the pileus to the roof of a turret)

P. cervinus (cevvus, deer-from the fawn-brown pileus), The Deer." Plate XLII. I 9.

P. 2-4 in., somewhat wrinkled, bell-shaped, then plane; umber, dark brown at maturity. $G$. free, crowded, white at first, then salmon colour. S. $2-4$ in., pale, covered with blackish strealss. Common on trunks, stumps, chips, etc., spv. and aut. Solitary. Sometimes much exceeding the above measurements. 


\section{ANNULARIA}

(From the annulate stem)

A. lævis (lavis, smooth-the usual state of the pileus).

$P .3$ in., subumbonate, glabrous, white. G. free, somewhat crowded; white at first, then salmon colour. S. 5-6 in., slender, attenuated upwards, smooth, white. $R$. somewhat distant, large. A rare species. In aut., amongst grass in bushy places.

\section{VOLVARIA}

\section{(From the volva)}

V. Loveiana* (after the Rev. R. T. Lowe). Plate XI. 7. P. 2-3 in., silky, white. $G$. free, white, then pale salmon colour. S. $1 \frac{1}{2}-2$ in., attenuated upwards, bulbous, closely fibrillose, solid, white. $V$. with a free margin, irregularly lobed, white. A rare species of remarkable habitat, living as a parasite, on half-decayed and more or less distorted specimens of Clitocybe nebularis. Worthington G. Smith remarks that it also occurs on other species of Clitocybe, and that a mycelium similar to that which gives rise to this species occurs also on the pileus of Tricholoma grammopodium.

V. parvula (parvulus, small). Plate XLII. 6.

$P$. up to I in., campanulate, then plane and umbonate, dry, silky, white, the umbo darker. G. free, crowded, white, becoming pale flesh colour. S. I-I $\frac{1}{2}$ in., stuffed, then hollow, white. $V$. large, lax, usually divided into three or four equal segments. In the var. biloba the stem is stuffed, never fistulose, and the volva is bi-lobed. In greenhouses, gardens, and fields. Frequent. A very neat little species.

* Thus named by Berkeley, but it was originally and very appropriately described by Knapp as Agaricus survectus, who figured it in his delightful "Journal of a Naturalist." 


\section{CHLOROSPOR Æ}

Spores clear green or bluish-green.

\section{CHLOROSPORA}

(Gr. chlovos, greenish-yellow; sporos, a seed-from the greenish spores)

C. Eyrei (after the Rev. W. L. W. Eyre, who first observed it). Plate XLIII. 2.

P. I $\frac{1}{2}$ in., broadly umbonate, smooth, brownish, margin incurved, apex minutely granular. $G$. free, narrowed behind, crowded, then distant, pale green at first, deep bluish-green at maturity. Spore mass deep bluish-green. Under spruces and beeches in aut., gregarious. Rare. Easily recognised by the bluish-green gills. The only known European representative of the genus.

\section{LEUCOSPOR $\mathbb{E}$}

Spores white. In the majority of the species the gills are white at maturity; the genera Russula and Lactarius contain some species witb cream-colour, or ochraceous, gills and spores.

\section{SCHIZOPHYLLUM}

(Gr. schizo, to split; phullon, a leaf-from the split edge of the gills)

S. commune (communis, common-it being common in certain countries). Plate XLV. 6.

P. $\frac{1}{2}$-I $\frac{1}{2}$ in., fan-shaped, thin, dry, horizontally attached to the matrix, often growing in an imbricate manner, margin entire or lobed, cottony, whitish, indistinctly zoned. $G$. narrow, radiating, grey, then purplish brown, more or 

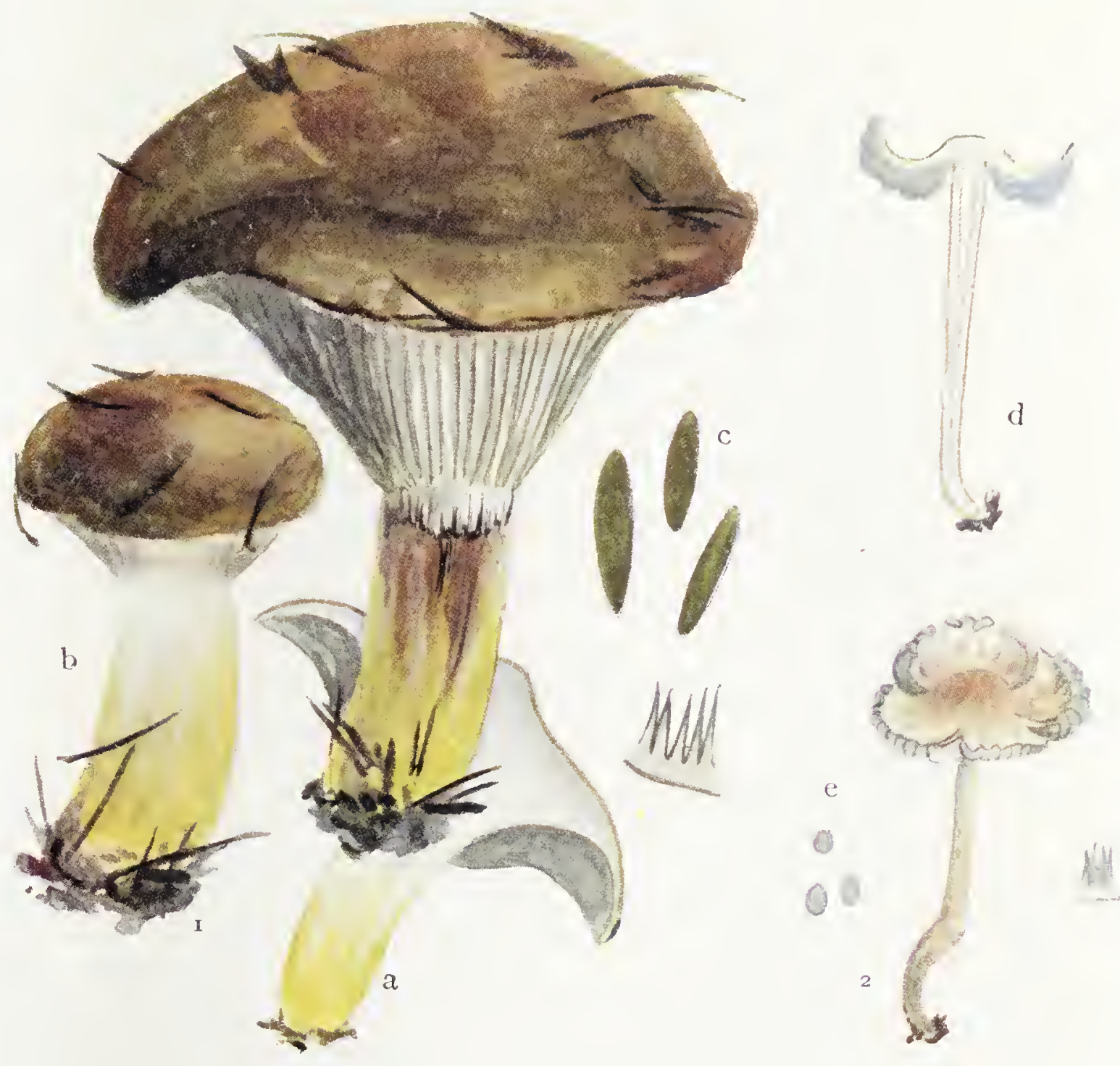

I, Gomphidius glutinosus: (a) section showing the bright yellow flesh at the base of the stem; (b) young plant; (c) the large, elongated, and fusiform spores (highly magnified). Below is a tangential section of the pileus and gills.

2, Chlorospora Eyrei: (d) section: (e) the elliptical green spores (highly magnified); to the right a tangential section of the pileus. (Erom drawings by Mrs. Carleton Rea.) 



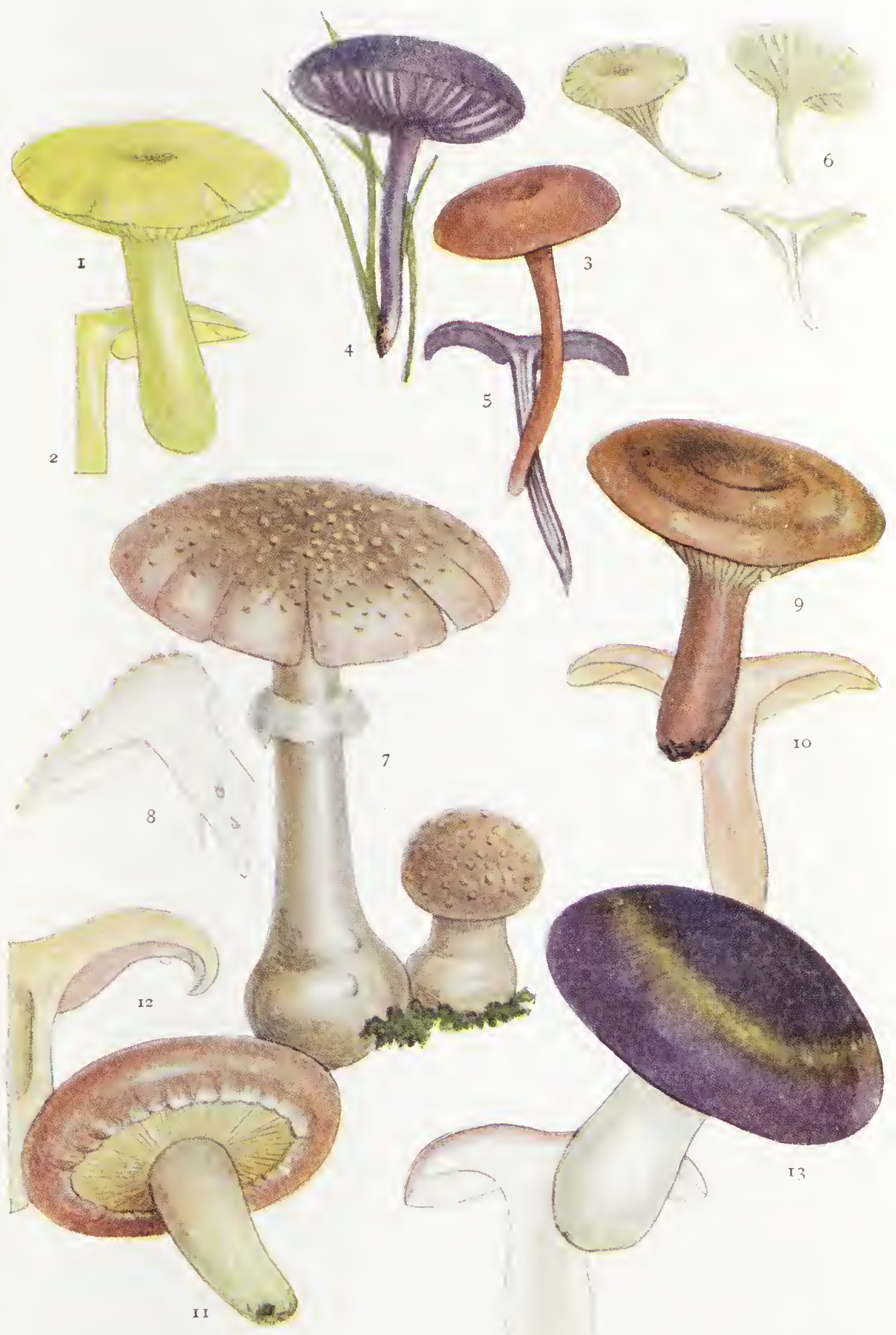




\section{DESCRIPTION OF PLATE XLIV}

WHITE-SPORED AGARICS (LEUCOSPORÆ)-I

FIG. I.-Tricholoma sulphureum.

FIG, 2.-Ditto, section.

FIG. 3.-Clitocybe laccata, typical form.

FIG. 4.-Ditto, var, amethystina.

FIG. 5.-Ditto, section.

FIG. 6. - Omphalia umbellifera, the pale form: two plants and section showing the distant decurrent gills.

FIG. 7.- Amanita rubescens, young and mature.

FIG. 8.-Ditto: section showing the thick reddish flesh and free gills.

FIG. 9.-Lactarius quietus.

FIG. I0.-Ditto: section showing the reddish flesh.

FIG. II.-Lactarus torminosus: young plant showing the incurved and shaggy whitish margin.

FIG. I2.-Ditto, section.

FIG. I 3.-Russula cyanoxantha.

FIG. I4.-Ditto: section showing the broad white gills and thick flesh. 
less deeply split at the margin, the lobes becoming involute and appearing tubular in transverse section. On rotten trunks, foreign logs, beer-casks, alder, beech, etc.; also on dry hay in silos. Rare in Britain.

\section{TROGIA}

\section{(After Jacob Gabriel Trog, a Swedish botanist)}

T. crispa (from the crisped gills). Plate XLV. 3 .

$P . \frac{1}{2}$-I in., cup-shaped at first, resembling a Peziza, then reflexed and irregularly lobed, almost flat, a little downy, yellowish-brown, margin whitish. G. vein-like, resembling those of Cantharellus, in which genus it was formerly placed, edge obtuse, crisped, greyish - white. S. absent. Gregarious on dead branches in late aut. Rare in Britain. Sometimes nearly white.

\section{LENZITES}

\section{(After Harold Othmar Lenz)}

L. betulina (betula, birch-its usual habitat). Plate XLV. I3.

P. 3-4 in., attached by a broad, expanded base, superficially resembling Auricularia mesenterica, pale brown, tomentose, usually slightly zoned, firm and corky. G. broad, thin, straight, simple, or branched (occasionally anastomosing), dingy-white. Perennial on trunks and stumps, especially birch and oak; often imbricated. Common in England, rare in Scotland.

L. flaccida differs in the very thin pileus, which is narrowed behind, not attached by a broad base, frequent on beech.

L. sæpiaria (sapis, a hedge-from its habitat) grows on firwood only. 


\section{XEROTUS}

(Gr. xeros, dry; ous, an ear-from the ear-like shape and dry substance)

$\mathrm{X}$. degener (degener, degenerate-not so highly developed as other members of the genus). Plate XLV. 9.

$P$. about I in., very tough, thin, membranaceous, corky, plane, then infundibuliform, greyish-bay and striate at first, grey and more or less zoned when dry. G. very few, very distant, decurrent, simple or dichotomous, greyish-white, first appearing as ribs or ridges. $S$. I in. (often much less), very tough, thin, brown, with a white downy coating. In peat-mosses and on naked soil in winter. Rare in Britain.

\section{PANUS}

(A name given by Pliny to an arboreal fungus)

P. stypticus (stypticus, astringent-from its taste). Plate XLV. I6.

P. $\frac{1}{2}-\mathrm{I} \frac{1}{2}$ in., dry, thin, not membranaceous, cinnamon, becoming yellowish-buff, scurfy. G. thin, narrow, crowded, connected by veins or thin ridges, cinnamon. $S$. $\frac{1}{2}$ in., lateral, solid, compressed, paler than the pileus. Gregarious aut. and win., usually imbricated on decaying stumps, especially cut surface of oak and chestnut-stumps. Common. Taste remarkably hot and pungent.

\section{LENTINUS}

(Lentus, tough or pliant-from the tough substance)

I. cochleatus (cochlea, a snail-shell-from the somewhat shell-like pileus), "Snail-shell." Plate XLV. I.

P. I-2 in., tough, flexible, irregularly lobed and twisted, depressed, sometimes infundibuliform, reddish-cinnamon. $G$. somewhat decurrent, crowded, margin serrate, pinkish- 

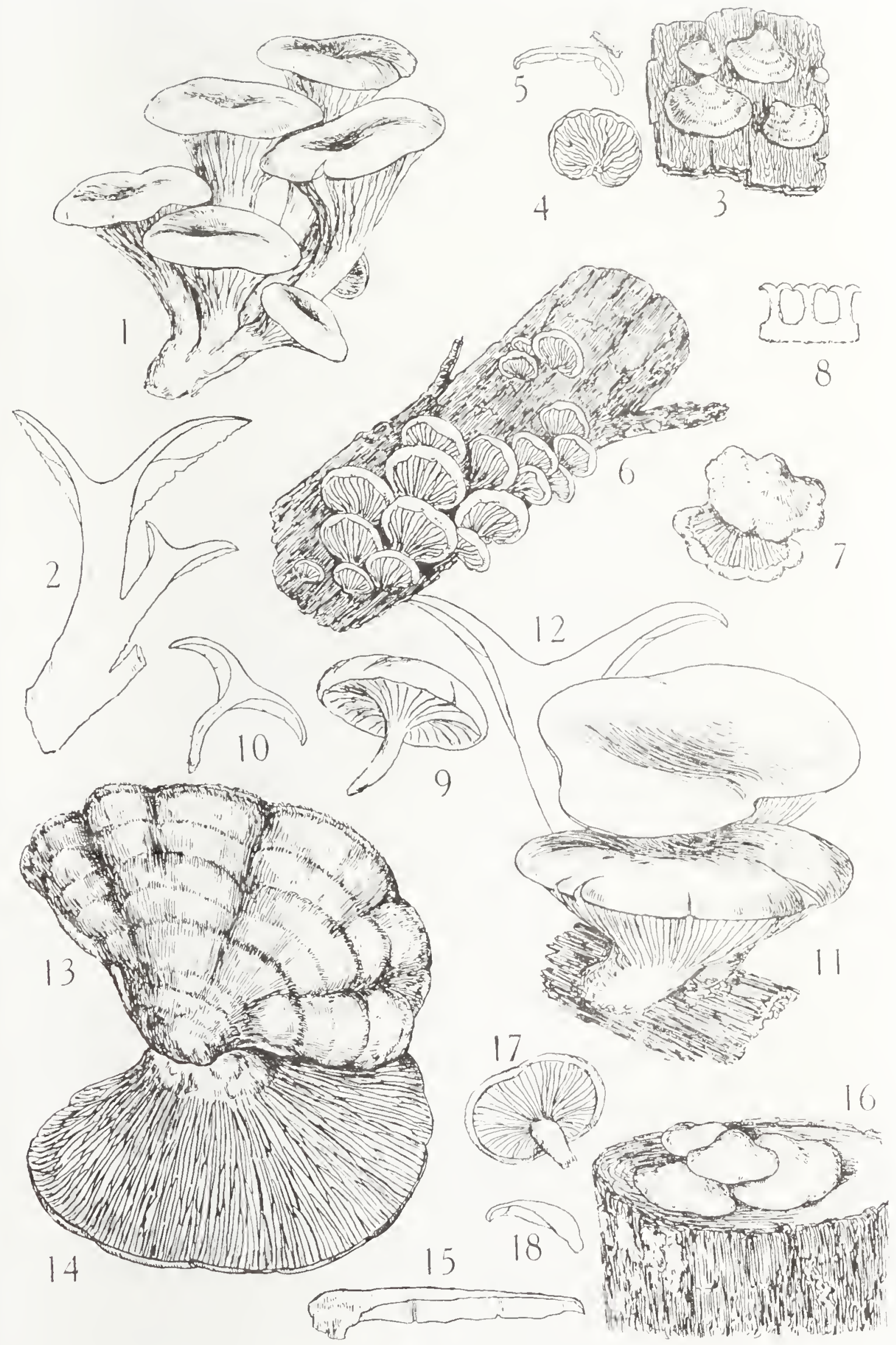


\section{DESCRIPTION OF PLATE XLV}

\section{SOME LEATHERY AND CORKY AGARICS}

FIG, I.-Lentimus cochleatus.

FIG. 2.-Ditto: section showing the confluen: stems.

FIG. 3.-Trogiar crispa.

FIG. 4.--Ditto, showing the fold-like and crisped gills.

FIG. 5.-Ditto, section.

FIG. 6.-Schizophyllum commune: group of imbricated plants.

FIG. 7.-Ditto, showing the indistinctly zoned pileus.

FIG. 8.-Ditto: section showing the split margin of the gills.

Fig. 9.-Xerotus degener.

FIG. IO.-Ditto, section.

Fig. II. - Panus torulosus.

F1G. I2.-Ditto: section of mature plant showing the infundibuliform pileus and narrow decurrent gills.

FIG. I3.-Lenzites betulina, showing the zoned pileus.

FIG. I4 - Ditto: the radiating corky gills.

FIG. I5.--Ditto, section.

FIG. I6.--Pamus stypticus: imbricated pilei on wood.

FIG. I7.-Ditto, showing tlie lateral stem.

FIG. I8.-Ditto, section. 
white. S. very variable, solid, smooth, a little paler than the pileus. "Very much tufted. Several stems are confluent in such a way as to make it doubtful whether the several pilei are really distinct, or are only lobes of one large one, the circle of the gills being always incomplete on the side of the common centre, the whole forming a lobed funnel with deflected edges" (Berkeley). Frequent at the base of old beeches, etc., in aut. Smell strong, agreeable, spicy, penetrating a considerable distance. Said to be edible.

\section{CANTHARELLUS}

(Gr. kantharos, a cup-from the cup-shaped pileus of some species)

C. cibarius (cibaria-from its use as food), "Chantarelle." Plate XV. 3.

P. I-4 in., glabrous, lobed, and wavy. $F$, thick, whitish. $G$. decurrent, distant; thick,' like swollen veins or folds; sinuate. S. I-2 in., stout, thicker above than below. Entire plant the colour of egg-yolk or opaque yellowish-buff; scentless when first gathered, developing an odour resembling that of fresh apricots in a few hours. Common in late sum. and aut. in woods, especially under beech. Subgregarious or in rings. Edible.

C. aurantiacus (aurantiacus, orange-yellow), "False Chantarelle." Plate VII. I.

P. I-2 in., depressed, irregular, and wavy; pale orange. $F$. thin. $G$. decurrent, crowded, rather thin, striated; usually bright orange, sometimes the colour of the pileus. $S$. about I in. thick, stuffed or imperfectly hollow, coloured like the pileus. Gregarious. Common on sandy heaths and in fir woods in ant. Supposed to be poisonous. The mould commonly seen on the gills is Dactylium dendroides, the conidial condition of Hypomyces mellens. 


\section{NYCTALIS}

(Gr. mx, night-from the habit, growing in dark places)

N. parasitica (from its parasitic habit). Plate XI. 3.

$P . \frac{3}{4}$ in., grey, conical, then expanded. G. adnate, distant, thick, brownish. S. I-3 in., slender, wavy, equal, whitish. Gregarious or cæspitose on rotting Russula nigvicans, $R$. adusta, R. fatens, and $R$. delica. Common in aut.

$N$. asterophora (aster, a star ; fero, to bear-from the minute stellate conidia on the pileus). Plate XI. I.

$P$. $\frac{1}{2}$ in., conical, then hemispherical; mealy, whitish. $G$. adnate, distant, narrow, dingy. S. $\frac{1}{2}$ in., slender, twisted, rather mealy; white at first, then brownish. Autumnal. Gregarious or slightly cæspitose on old blackened specimens of $R$. nigvicans, R. adusta, Collybia fusipes, and a few other agarics. "The stellate conidia on the pileus have been named Hypomyces asterophorus" (W. G. Smith).

\section{HYGROPHORUS}

(Gr. hugros, moist; phero, to bear-from the water-bearing character)

This genus is divided into three sub-genera as follows:

Sub-genus 1.-Hygrocybe.

Veil absent. Pileus viscid when moist, shining when dry. Stem not ornamented with scales or wart-like projections. Gills soft.

Sub-genus 2.-Camarophyllus.

Veil absent. Pileus not viscid when moist, firm and opaque when dry. Gills distant, arcuate.

\section{Sub-genus 3.-Limacium.}

Universal veil viscid; partial veil floccose, often forming a trace of a ring, or attached to the margin of the pileus. Stem ornamented with scales or wart-like projections. Gills adnato-decurrent.

All are terrestrial and gregarious, usually appearing in meadows soon after the first frosts of autumn. 
SUB-GENUS I.-HYGROCYBE

(Gr. hugros, moist ; kube, head-from the moist pileus)

Hygrophorus coccineus (coccinens-from its scarlet colour), "Scarlet-hood." Plate IX. 4.

P. I-2 $\frac{1}{2}$ in., viscid when moist; bright scarlet, becoming pale; often irregular. $G$. broadly adnate, with a decurrent tooth; distant, connected by veins, wrinkled; purplish at the base, pale yellow towards the middle, edge glaucous at maturity. S. $\mathrm{I} \frac{1}{2}-2$ in. thick, not shining, more or less hollow; tough, but splitting easily; crimson above, always pale yellow at the base. Very common amongst grass and moss in fields and open places.

H. miniatus (minium, vermillion) is another blood-red species, appearing in fields in July. P. I in., squamulose, umbilicate and bleached at maturity, flesh scarlet, base of stem never yellow.

H. puniceus (punicens, blood-red) is one of the largest representatives of the genus. $P \cdot 2-4$ in. The larger size, adnexed gills, and striated stem, with white base, easily separate it from $H$. coccineus.

H. ceraceus (ceva, wax) differs from all other members of the sub-genus in the unchangeable wax-yellow hue of every part, P. I in., fragile.

H. conicus (from the conical pileus).

$P$. I-2 in., broad and high, margin lobed, viscid when moist; yellow, orange, scarlet, etc. $G$. narrowed behind and almost free, yellowish, rather crowded. S. 3-4 in., stout, variously coloured, often splitting. Remarkable in usually turning black with age and when bruised. Very common in meadows in late sum. and aut.

H. chlorophanus (Gr. chlovos, greenish-yellow; pharo, to appear) does not become black when bruised, and the pileus is obtuse, never conical. It differs from $H$. ceracens in 
the bright sulphury-yellow colour (sometimes crimson though), watery substance, and emarginate gills.

$H$. calyptræformis (calyptra, a hood-from the pointed hood-shaped pileus), an uncommon species, with the habit of $H$. conicus. May be at once known by the beautiful clear rose-coloured pileus and long white stem. Probably of triennial appearance. The var. miveus is wholly white.

H. psittacinus (psittacus, the ringed green parrot-from the yellow or red and green colours), "Parroquet." Plate IX. 7 .

$P$. I in., campanulate, then expanded, more or less umbonate; yellow or orange; covered at first with a green gluten. G. adnate, distant, thick, yellow, more or less shaded with green. S. I-3 in., slender, equal, hollow; yellow below, green above. Common in pastures; easily known by the peculiar colour.

\section{SUB-GENUS 2.-CAMAROPHYLLUS}

(Gr. kameva, a vault; phullon, a leaf-from the arcuate gills)

Hygrophorous pratensis (pratum, a meadow). Plate IX. I I.

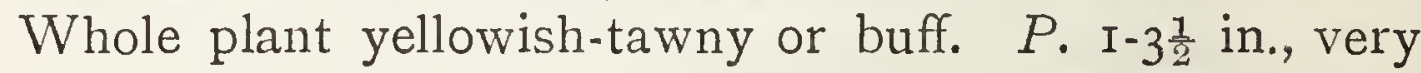
fleshy at the disc, shape variable, moist in wet weather, but never viscid. $F$. white and firm. $G$. very decurrent, very distant, very broad (in the middle), veined. $S$. I- $2 \frac{1}{2}$ in., stout, stuffed, polished. Common. Sometimes wholly white, in which condition it might be mistaken for $H$. virgineus.

H. virgineus (from the pure white colour), "Virgin." Plate XLVI. I2.

Whole plant white. $P \cdot I_{\frac{1}{2}}^{\frac{1}{3}} 3$ in., convex, soon plane, moist, downy when dry, fleshy in the centre. $G$. decurrent, distant, thick. S. $I_{2}-2$ in., attenuated below, firm, smooth, solid. Common in fields. Edible. Said to be delicious boiled.

H. niveus (nivens, snow-white) is equally common. It 
appears later than $H$. virginells; is a more slender and tougher plant, with membranaceous pileus. It superficially resembles Clitocybe evicetormm, which is shining when dry. The mould which sometimes clouds the gills of the two preceding species is Verticillium Marquandi.

\section{Sub-GENUS 3.-LIMACIUM}

(Limax, a slug-from the glutinous pileus and stem)

Hygrophorus cossus (from its odour of the goat-moth, Cossus ligniperda), "Goat-moth."

$P$. I-2 in., fleshy, glabrous; glutinous at first, shining yellowish-white when dry. $F$. white. $G$. adnato-decurrent, connected by veins, white. S. 2-3 in., slender, equal, white, or yellowish-white. Frequent amongst grass in woods and pastures. Known by its unpleasant smell, which exactly resembles that of the larva of the goat-moth.

H. eburneus (ebur, ivory) is pure shining white, never yellowish and never strong-smelling; superficially resembling Tricholoma lascivum.

H. chrysodon (Gr. chrusos, gold; odous, a tooth-from the golden tooth-like scales) is pure white, with the margin of the pileus and the apex of the stem tinged yellow. Smells like the larva of a goat-moth. A rare species.

\section{PLEUROTUS}

(Gr. plewron, a side; ous, an ear-from the supposed resemblance of many species to an ear)

P. ulmarius (ulmus, elm-its usual habitat), "Elm-sprout." Plate XXXVI. Iо.

P. 3-9 in., smooth, horizontal, more or less eccentric, livid, then pale; usually marbled with roundish spots. $F$. thick, white, tough. G. slightly adnexed, emarginate 
and rounded behind, broad, somewhat crowded, whitish. S. eccentric, 2-3 in:; about I in. thick, white. Singly or in tufts on trunks of various trees, chiefly elm, in aut. and win. Not common:

P. ostreatus (ostrea, an oyster-from the colour of the pileus), "The Oyster."

P. 3-6 in., imbricated, convex, with involute margin at first, then expanded and ascending, glabrous, moist, even (sometimes squamulose), dark when young, then brownish or bluish-grey. Often tinged with violet or lavender, usually becoming yellowish at maturity, shining and satiny when dry. $G$. decurrent, rather distant, broad, white; sometimes yellowish, never tinged pink. S. very short or absent, firm, swollen above, white and downy below. "Cæspitose. Smell strong. The stem is sometimes almost central. Distinguished from all species, except $P$. corticatus (which is rare), by the gills anastomosing behind, and often forming an open network on the stem-like base. Known from $P$. corticatus by the absence of a ring on the stem " (Massee). Frequent on trunks of various trees in aut., win., and spv. Dr. Plowright observed it growing on the dried brain of a stranded whale. The var. enosmos is easily recognised by the lilac or purple tinge of the spore mass and the strong smell of tarragon.

P. septicus (septicus, putrifying-from its habitat, rotten wood). Plate XXXVI. 9.

Entirely white. $P \cdot \frac{1}{2}$ in., downy, at first resupinate, with a minute downy stem, which disappears as the pileus becomes reflexed. $G$. radiating from the point of attachment of the stem, broad, rather distant. "Small, but very variable in form. Superficially resembling Claudopus variabilis, but the gills are persistently white, as are also the spores. Distinguished from the other small white species of Pleurotus by the thicker flesh of the pileus and more evident stem, and by the gills being at first uppermost, and 
then turned over" (Massee). Frequent in sum. and aut. on decaying branches, twigs, wood, etc.

P. hypnophilus (Hypmum, a moss genus; philos, lovingfrom its usual habitat), "Moss Pleurotus." Plate X. 2.

$P$. up to $\frac{1}{2}$ in., flat, very thin, resupinate, almost smooth. $G$. radiating from the point of attachment of the pileus, narrow, distant. "Resembling Claudopus variabilis closely in size and general appearance, but the spores are white, and the gills do not change colour. Distinguished among the small white species of Pleurotus by the glabrous pileus" (Massee). On moss and fallen leaves in aut. Frequent.

\section{OMPHALIA}

(Gr. omphalos-from the umbilicus)

o. umbellifera (umbella, an umbel; fero, to bear-from the umbrella-lilie pileus), "Little Umbrella." Plate XLIV. 6.

$P . \frac{2}{3}$ in., convex, then almost flat; sometimes wavy or upturned; margin at first incurved and crenate; somewhat striate when moist, even and more or less silky when dry; greyish-yellow, brownish, etc. G. decurrent, very distant, broad behind, almost triangular, whitish, or coloured like the pileus. S. $\frac{1}{2}$ in., slender, base downy, imperfectly hollow, colour of pileus. Common in damp places, open fields, rotten wood, etc., except in win. The entire plant is pale yellow in the var. abiegna, which grows on decaying firwood. The var. vividis is entirely pale green.

o. fibula (fibula, a pin-from its shape).

$P$. $\frac{1}{2}$ in., membranaceous, margin drooping, then expanded, usually umbilicate, finally quite infundibuliform; obscurely striated when moist, hygrophanous, glabrous, orange-yellow or brownish, or entirely white. G. deeply decurrent, distant, distinct, broad, whitish. S. I-I $\frac{1}{2}$ in., very slender, the colour of the pileus; stuffed at first, then hollow. Common in damp, mossy places and on burnt 
ground. The var. swartzii is a firmer plant, differing in the almost plane, whitish pileus, with dark disc and whitish stem, with the apex tinged with violet.

\section{CLITOCYBE}

(Gr. klitos, a declivity ; kube, a head-from the decurrent gills)

GROUP I.-PILEUS FLESHY, PALE AND MINUTELY SILKY

WHEN DRY. FLESH FIRM; NOT HYGROPHANOUS

C. nebularis (nebula, a cloud; the greyish pileus being frequently clouded with white mycelium), "Cheese-cap."

P. 2-5 in., convex, then plane, often gibbous when young. Smoky-brown, becoming livid or grey; sometimes pruinose. F. white, thick at the disc, thinner at the margin. $G$. slightly decurrent, arcuate, crowded; greyish-white. S. 2-3 in., stout, a little attenuated upwards, fibrillosely striate, firm, stuffed; dingy-white. Smells like curd cheese. Common in aut. amongst dead leaves in woods. The white mycelium on the pileus gives rise (rarely) to Volvavia Loveiana (see Plate XI. 7).

C. clavipes (clava, a club-from the shape of the stem) is the colour of the preceding, but only half the size. $G$. deeply decurrent. S. dark, solid, markedly attenuated upwards. Common in pine-woods.

C. phyllophila (Gr. phullon, a leaf; philos, loving) is wholly whitish tan.

P. I-3 in. S. 2-3 in. A somewhat cæspitose, tough species common amongst leaves (especially beech) in aut.

C. pithyophila (Gr. pitus, pine; philos, loving) is a wholly white species, frequent in pine-woods. "Gregarious or slightly cæspitose. Allied to C.phyllophila, but distinguished by the persistently white gills and white pileus. Smell pleasant. C. tuba closely resembles the present species, but differs in the deeply decurrent gills" (Massee). 
C. dealbata (dealbatus, whitewashed) and C. gallinacea (gallina, a hen-from its colour, like a hen's egg) are two small white autumnal species agreeing in stature ( $P$. I- I $\frac{1}{2}$ in.) and in the slightly decurrent gills. C. dealbata is inodorous. $P$. plane, then upturned and wavy, ivory-like. S. I in., hollow. C. gallinacea is strong-smelling and acrid. S. I I $\frac{1}{2}$ in., solid. Both occur amongst grass and moss in sunny places. One form of dealbata frequently occurs in old mushroombeds.

C. ericetorum (ericetum, a heath-from its habitat) is a more or less infundibuliform species, differing from the above in the distant, truly decurrent gills. It much resembles Hygrophorus nivens.

There are two species included in this group-viz., C. odova and C. Trogii-remarkable for their fragrant smell. C. odora (odovus, fragrant).

P. 2 in., soon plane and wavy, even, pale bluish-green, silky when dry. $G$. adnate, broad, pallid or greenish. $S$. I-I $\frac{1}{2}$ in., slender, swollen below, stuffed. Common in woods in aut. Its presence is at once indicated by the pleasant smell of aniseed.

C. Trogii (after Trog, a Swedish botanist) is a stouter species, with dingy pale-grey pileus, whitish gills, and solid stem. Amongst leaves in woods in aut.

C. fragans (fragans, sweet-scented), a hygrophanous species, differs from the two preceding also in its smaller size $(P$. I in.) and uniformly whitish colour. Common amongst moss and leaves in woods and pastures bordering them from July to Jan. "Very remarliable for its power of standing cold. On Dec. 30, I882, I gathered it after very severe frost (Ther. o) for three nights in succession, and a week of complete thaw, in a perfectly fresh condition, and with the smell unchanged" (Stevenson). The mould which occurs upon it is Sporodinia aspergillus.

A very natural section of the non-hygrophanous group IO-2 
comprises plants that at maturity are either deeply infundibuliform, or with the centre of the pileus deeply umbilicately depressed. The following are well known :

C. maxima (maximus, the greatest).

P. 6-I2 in., broadly infundibuliform and somewhat umbonate, pale tan or whitish, margin involute, even, slightly silky or downy at maturity. $G$. deeply decurrent, rather crowded, whitish. S. 3-4 in., stout, attenuated upwards. Frequent in sum. and ant. in woods and pastures, banks and hedges.

C. gigantea is closely allied to the preceding.

$P$. 6-Io in. G. broad, slightly decurrent. $S$. seldom exceeding 2 in., very thick. Autumnal, in woods. Uncommon.

C. geotropa (Gr. ge, the earth; tvepo, to turn-from the often strongly deflected margin of the pileus).

P. 2-5 in., differs from C. maxima in its firmer substance, and glabrous pinkish-tan or buff pileus, which is obtusely umbonate, the umbo always remaining after the pileus has become depressed.

C. infundibuliformis (infundibulum, a funnel; forma, form)

$P .3$ in., margin involute, umbo gibbous; convex, then depressed. At maturity entirely infundibuliform; more or less reddish, yellowish, flesh colour, or buff, becoming pallid. $G$. truly decurrent, much narrowed at both ends, rather crowded, white. S. 2-3 in., slender, firm, stuffed, attenuated upwards. Common amongst moss in fields and woods in sum. and aut. Fries observes that $C$. catina (catimus, a bowl-from its bowl-shaped pileus) is "allied to C. infundibuliformis, having the same pleasant smell, but differs in being white at first; pileus never gibbous, glabrous, but when quite young with superficial down, which soon disappears. Clitocybe phyllophila differs in the pileus never being infundibuliform, slender stem, adnate gills, and absence of smell." 
C. flaccidus (faccidns, limp-from the limp pileus). Plate XLVI. Io.

$P .2-3$ in., umbilicate, always without an umbo; margin spreading, arched, persistently shining, tawny, ferruginous. $G$. deeply decurrent, crowded, narrow; white at first, then yellowish. S. I-2 in., somewhat hollow, tough, polished; reddish rust colour; base thickened, downy. Frequent in aut. amongst leaves, etc., in woods. Usually gregarious. Superficially resembling Lactarius subdulcis. The var. lobatus is cæspitose, pileus darker, with lobed or contorted margin.

GROUP II.-PILEUS HYGROPHANOUS, THIN AND WATERY

C. cyathiformis (cyathus, a cup; forma, form).

$P$. I $\frac{1}{2}-3$ in., plano-depressed, then infundibuliform, slimy; dark-brown when moist, becoming pale when dry, the margin remaining involute for a long time. $G$. adnate, becoming decurrent with the alteration in the shape of the pileus; greyish-brown. S. 2-4 in., slender, attenuated upwards, the colour of the pileus, with brownish fibrils; apex naked; base hairy. Common in aut. in woods and pastures; rarely on rotten wood. Gregarious.

C. brumalis (bruma, winter-from the time of its appearance).

P. I-I $\frac{1}{2}$ in., umbilicate, then infundibuliform; often with wavy and lobed margin, glabrous, livid, then whitish or yellowish; disc often darker. G. decurrent, crowded, narrow, pallid. $S .2$ in., slender, nearly equal, slightly curved, glabrous, whitish. A truly autumnal species, not appearing before Oct.; most abundant in Nov., and lasting into Jan. Common in pine woods and amongst heather.

C. metachroa (Gr. metachroos, changing colour).

$P$. I-2 in., convex, then plane or depressed, never infundr- 
buliform; brownish-grey, whitish when dry. $G$. adnate scarcely decurrent, crowded, greyish-white. S. $1 \frac{1}{2}$ in., very slender, tough, soon hollow, fibrous outside, easily compressed, grey, apex with white meal. Common in dry pine woods in aut. A variable species; easily known, however, by the absence of smell, the mealy apex of the stem, greyish-white gills, and the subumbonate, then plane and depressed, pileus.

C. laccata (from the red colour of the pileus resembling gum-lac). Plate XLIV. 3-5.

P. I- $2 \frac{1}{2}$ in., convex, umbilicate, often more or less wavy and irregular; flesh thin. There are two very distinct colour forms-one a rich, deep reddish-brown, the other a bright amethyst (var. amethystina); in both the pileus becomes pallid or dingy-white, and minutely squamulose when old and dry. G. broadly adnate, distant, always the colour of the pileus, powdered white with the spores at maturity. S. 2-3 in., slender, tough, stuffed, the colour of the pileus. Woods and hedges. Usually gregarious, June to Dec. Very common.

\section{LACTARIUS}

\section{(Lac, milk-from the milky juice)}

Closely allied to Russula, differing in the abundant granular milk (latex) which flows or drops from the pileus and gills when broken. The milk is usually white; in a few species it changes colour on exposure to the air ; and in one it is coloured from the first. Taste very variable-from mild to intensely acrid. The peculiarities of the milk are of importance in specific diagnosis. The numerous species are arranged in four sections as follows :

\section{Section I.-Piperites}

Stem central. Gills not becoming discoloured. Milk white at first, and usually acrid. 


\section{Section II. -Dapetes}

Stem central. Gills naked. Milk coloured from the first.

\section{Section III.-Russularia}

Stem central. Gills pallid, then discoloured, becoming powdered with the white spores. Milk white at first, mild, or mild becoming acrid.

Section IV.-Pleuropus

Stem excentric or lateral.

\section{SECTION I.-PIPERITES}

L. torminosus (tormina, gripes-from its extreme acridity). Plate XLIV. II.

P. 2-5 in., viscid when moist, slightly zoned, a beautiful ochre or pale flesh colour; margin strongly incurved for some time, shaggy, whitish. F. pallid. Milk white, very acrid, not changeable. $G$. slightly decurrent, very narrow and crowded, yellower and paler than the pileus. S. I $\frac{1}{2}-3$ in., thick, slightly hairy or almost glabrous, attenuated below, dry, stuffed, soon hollow, colour of pileus or paler. Common in aut. amongst heather. In spite of its acridity, this species is preserved in salt for winter use in Russia, and eaten with oil and vinegar. The white mould, changing to yellow and dark brown, frequently seen on the gills, is Hypomyces torminosus.

I. cilicioides (Gr.kilikion, goat's-hair cloth ; eidos, appearance-from the tomentose pileus), frequent in similar situations; differs from the preceding chiefly in the dingy or darker stem, absence of zones on the pileus, and the yellowish milk. It is the connecting link with $L$. turpis (turpis, base-from its ugliness), which may be easily recognised by the dark zoneless pileus covered with a tenacious olive gluten, the yellowish-olive and strongly incurved downy margin, and the solid, hard stem. It is a gregarious species, very common in aut. in woods and by roadsides, especially on sandy soils. 
L. blennius! (Gr. blemos, mucus), another species with glutinous pileus, bears much superficial resemblance to L. turpis, but the pileus is not so dark (dingy greenish-grey), is concentrically pitted or zoned, and does not long remain involute. The stem quickly becomes hollow.

I. piperatus (piper, pepper-from its taste).

P. 4-8 in., umbilicate at first, then infundibuliform, with erect margin, zoneless, glabrous, dry, white. $F$. white, milk white, very copious and very acrid. $G$. decurrent, crowded, "like the teeth of an ivory comb," very narrow, white or cream colour. S. I $\frac{1}{2}-2 \frac{1}{2}$ in., stout, smooth, solid, mealy-white. Common in woods in aut., probably triennial. Easily known by the absence of colour and the very acrid taste. $L$. controversus ( $P$. at first convex, then infundibuliform), found chiefly under poplars, is of similar habit, but may be at once identified by the reddish zones, blotches, or spots on the pileus, and the flesh-coloured gills at maturity. This species is eaten at Lucca, under the name of "Lucchese Goat." L. velleveus (vellus, fleece), the great white Woolly Lactar, may be known from $L$. piperatus by its broader distant gills, tomentose pileus, and scanty milk. Sometimes the milk is absent; it is then separated from Russula delica by the floccose or downy pileus and very acrid taste.

\section{Section II.-DAPETES}

I. deliciosus (from its flavour when cooked). Plate XV. 6.

$P$. 3-5 in.,. viscid, margin incurved at first, orange-red, greenish when old, zoned. Milk saffron-red, sweet-scented, very copious. $G$. decurrent, narrow, colour of pileus or paler. S. I-3 in., stout, more or less pitted, smooth, usually paler than the pileus, stuffed, then more or less hollow. Gregarious. Late sum. and aut. Common in some localities in fir plantations. Abundantly distinct from all other members of the genus in the saffron-red milk, and in 
becoming dingy when bruised and with age. The gills are often attacked by a reddish mould, Hypomyces lateritins. Edible. The "vegetable sheep's kidneys" of French cooks. L. sanguifuns (sanguis, blood; fluo, to flow) differs only in the blood-red milk.

\section{SEction III.-RUSSULARIA}

L. quietus (quietus, mild-from its taste). Plate XLIV. 9. P. 2-3 in., obtuse, then depressed; of ten wavy and irregular viscid, cinnamon flesh colour at first; disc usually darker, becoming paler and dry. F. white, then tinged red. Milk persistently white and mild. $G$. slightly decurrent, white, then pale brick-red. $S .2-3$ in., thick, reddish-cinnamon; usually darker below, stuffed; "flesh firm, bearing a strong pressure without breaking; when old less firm, but not hollow, mild; odour oily, and sometimes that of bugs" (Berkeley). One of the commonest representatives of the genus, occurring, usually gregariously, in woods and thickets, by roadsides, etc., throughout the autumn. A somewhat showy species, never truly robust, always more or less soft.

L. theiogalus (Gr. theion, brimstone; gala, milk-from the sulphur-coloured milk).

P. I-3 in., convex, then depressed and infundibuliform, and sometimes papillate, glabrous, viscid, shining when dry, not zoned, tawny-rufous. G. adnato-decurrent, pallid, then rufescent. $S$. r-2 in., slender, stuffed, then hollow, tawny-rufous. Milk white at first and mild, slowly becoming sulphur colour and acrid. Frequent in aut. in mixed woods, pine, etc., and amongst heather.

L. rufus (from the reddish colour). Plate VII. 3.

P. 3-4 in., margin incurved at first, umbonate, then infundibuliform, the umbo always persisting, zoneless, dry, polished, rufous-bay or reddish-cinnamon when old. Milk 
persistently white and extremely acrid from the first. $G$. adnato-decurrent, crowded, yellowish at first, then palered. $S .2-3$ in., a little paler than the pileus, clothed with white down at the base, stuffed, fragile. Very common throughout sum. and aut. in dry pine woods. Gregarious. Abundantly distinctive, always bright reddish-cinnamon, always with an umbo and usually under firs.

L. subdulcis (dulcis, sweet-taste somewhat sweet), a reddish species ( $P$. I $\frac{1}{2}-2 \frac{1}{2}$ in.), common in pine and mixed woods; may be known from $L$. nufus by its sweet taste at first (becoming acrid if kept in the mouth a little time) and hollow stem at maturity.

I. serifluus (sevmm, whey; flu, to flow-from the watery milk) is allied to L. subdulcis, but is much smaller; the margin of the pileus is incurved, the stem is solid, and the scanty milk is the colour of whey. It is frequent in mixed woods and damp places. L. mitissimus (mitissimus, very mild-from its taste), a common woodland species also closely allied to L. subdulcis, is distinguished by the persistently mild milk, and the bright shining tawny-orange pileus and stem.

\section{Section IV.-PLEUROPUS}

I. obliquus (from the oblique stem).

$P$. about 3 in. (rarely 6 in.), lobate, whitish, zoned with grey. G. crowded white. S. about I in., rather excentric, curved, stuffed or hollow. Mill white. Occurring in Oct.in tufts on beech trunks, burnt stumps, etc. Uncommon. At once known by the habitat and excentric stem.

\section{RUSSULA}

(Russulus, reddish-from the frequently reddish colour of the pileus)

Rigid, brittle, and fleshy fungi; usually gregarious ; occurring in late sum. and ant. All are terrestrial. 
This genus is closely allied to Lactarius. Laticiferous cells are present in the flesh and gills, but the milk is very dense, and does not make itself evident when the plant is bruised or broken. As in Lactarius, the flesh, through the peculiarities of the millk, may be either very acrid or mild. This feature is used by some systematists as a basis for the grouping of species, and it has been followed in the subjoined descriptions of some well-known species. In the "mild" section, the milk in some species becomes slowly acrid if kept in the mouth for some time. Great discretion should be used in experimental tasting : a very small piece is quite sufficient for the diagnosis. Many species are so intensely acrid that serious inconvenience would result if a large piece were put into the mouth. It is scarcely necessary to add that it should not be swallowed.

\section{Section I. - Taste Mild}

I. Gills ochreous.

2. Gills pale or bright yellow; never tinged ochreous.

3. Gills white or creany-white, sometimes becoming blackish when old ; never yellow nor ochreous.

(a) Pileus white or cream colour at first, becoming blackish with age.

(b) Pileus clear yellow.

(c) Pileus green or olive.

(d) Pileus various shades of red and purple, or brownishorange, sometimes with a greenish tingue.

\section{Section II.-Taste Acrid}

I. Gills yellow or ochreous.

(a) Pileus yellow or ochreous.

(b) Pileus red or purplish.

2. Gills white or creamy-white; never distinctly tinged with yellow or ochreous.

(a) Pileus ochreous or umber.

(b) Pileus red or purplish. 


\section{SECTION I.-TASTE MILD}

\section{GILLS OCHREOUS}

R. alutacea (alut $\bar{a}$, tanned leather-from the colour of the gills).

P. 2-5 in., expanded and somewhat umbilicate at maturity, even, with a distinct viscid pellicle, deep blood-red, sometimes blackish-purple, usually paler at the disc. $F$. thin, snow-white. G. free thick, broad distant, all equal, connected by veins, yellow at first, then deep ochreous, never looking as if powdered. S. 2 in., stout, solid, equal, white, often variegated with red (sometimes purple). A large showy species, common in beech and mixed woods in ant.

$R$. integra (integer, entire-often of perfect form) is closely allied to the above, and is equally common. Differs in the pale-yellow gills, becoming dusted with the pale ochreous spores at maturity.

\section{GILLS YELLOW WITHOUT AN OCHREOUS TINGE}

R. puellaris (puellaris, girlish-from its small size and grace).

P. I-I $\frac{3}{4}$ in., almost membranaceous, except at the disc; tuberculosely striate at the margin, scarcely viscid; colour variable and peculiar-shades of purple, rose, and orange; disc always darker, brownish, sometimes nearly black, not shining. $G$. adnate or adnexed, thin, crowded, white, paleyellow at maturity, not powdered with the pale-yellow spores. S. I-2 in., equal, white becoming yellowish, soon hollow. A denizen of birch and pine woods, occurring in troops. Some of the colour forms have received varietal names, but all occur together and are difficult to separate. 
3. GILlS WHite OR CREAMY-WHite, NEVER YELLOW OR OCHREOUS, BUT SOMETIMES BECOMING BLACKISH WITH AGE-(A) PILEUS WHITE OR CREAM COLOUR AT FIRST, BECOMING BLACKISH AT MATURITY

R. nigricans (nigricans, becoming black-from its colour in decay).

P. 3-5 in., depressed, whitish at first, then sooty-olive, squamulose, black at maturity. F. firm, white, becoming reddish-black when old. $G$. adnexed, rounded behind, very thick, distant, broad, pale yellowish, becoming reddish when bruised. S. $1 \frac{1}{2}-2 \frac{1}{2}$ in., very thick, solid, pallid at first, then black. Common in mixed woods. Often infested by species of Nyctalis.

R. adusta (adustus, scorched-from its appearance) might be mistaken at first sight for small specimens of the preceding species, but the flesh does not turn red, and the gills are thinner, decurrent, and crowded.

R. densifolia (densus, thick; folium, a leaf-from the crowded gills as compared with those of $R$. nigvicans) resembles $R$. adusta, but the flesh turns red when broken.

\section{(B) PILEUS CLEAR YELLOW}

R. citrina (from the citron-coloured pileus), an uncommon inhabitant of mixed woods, is distinctive in the clear sulphur-yellow pileus (sometimes greenish), with brassyyellow disc, and the persistently white gills and stem.

\section{(c) PILEUS GREEN OR OLIVE}

R. heterophylla (Gr. heteros, one of two; phullon, a leaffrom the unequal length of the gills).

P. 2-4 in., depressed at maturity; colour variable, usually apple-green, clouded with brown, with never a trace of red 
or purple: $G$. almost free, very narrow, and very crowded (many shorter ones), forked, white. $S$. I $\frac{1}{2}-2 \frac{1}{4}$ in., equal, solid, white. Common in woods, etc. Easily known by the even polished pileus and the closely-crowded white gills.

R. furcata (furcatus, forked-from the forked gills).

$P$. 3-5 in., smooth, even, dark lurid green, umber-greenish or olive-tan; pellicle separable. $G$. adnato-decurrent, rather thick, more or less distant (sometimes crowded), broad, attenuated at both ends, forked, white. S. 2-2 $\frac{3}{4}$ in., stout, equal, white. Common in woods, and under trees in meadows, from May to Oct. The even pileus, with silky bloom and separable skin, and the frequently forked, thickish, and slightly decurrent gills are the chief points of distinction.

(D) PILEUS VARIOUS SHADES OF RED, PURPLE, OR BROWNISHORANGE; SOMETIMES WITH A GREENISH TINGE

R. cyanoxantha (Gr. kuanos, blue; xanthos, yellow--from the colours of the pileus). Plate XLIV. I3.

P. 2-3 $3 \frac{3}{4}$ in., viscid; colour very variable-shades of purple, red, and green-disc usually becoming pale or yellowish. $G$. rounded behind, almost free, broad, somewhat crowded, shining white. S. $2-2 \frac{1}{2}$ in., stout, equal, smooth, shining white, hollow when old. Common in moist spots in mixed woods. $R$. heterophylla and $R$. furcata sometimes resemble this species in colour. The former differs in the narrow, closely-crowded gills, the latter in the adnato-decurrent, thickish gills, and in becoming slightly acrid in the mouth.

$R$. vesca (vescus, eatable-from its edible qualities) differs from $R$. cyanoxantha in the constant flesh-red pileus and reticulately-wrinkled stem. 


\section{SECIION II.-TASTE ACRID}

I. GILLS YELLOW OR OCHREOUS-(A) PILEUS YELLOW OR OCHREOUS

R. fellea (felleus, full of gall-from the very bitter and acrid taste). Plate VIII. 6.

P. I-4 in., polished, smooth, straw colour, ochre or buff, disc usually brownish. $G$. adnate, more or less crowded, thin, narrow, sometimes exuding drops of water in damp weather, straw colour. $S$. about 2 in., white and stuffed at first, yellowish and hollow at maturity. A common inhabitant of beech-woods; easily recognised by the intensely acrid taste and pale-straw colour of every part, including the flesh. It is often mistaken for $R$. ochracea, which differs in the mild taste.

\section{(B) PILEUS RED OR PURPLE}

R. drimeia (Gr. drimus, pungent_from its taste). Plate VII. 5 .

P. 2.4 in., somewhat viscid when moist, bright deep purple or dark-rose colour. G. adnexed, narrowed behind; pale sulphur colour at first, pale yellow at maturity. $S$. $2-3 \frac{1}{2}$ in., stout, solid, beautifully tinged with purple. Gregarious in fir woods, especially under larches, in ant. Intensely acrid. Cooke remarks: "So intensely peppery that, after tasting a small fragment, the tongue tingled for more than half an hour."

R. rubra (nibev, red-from the colour of the pileus) has an absolutely dry, even deep blood-red pileus, with mild flesh and broad, adnate gills, with very acrid taste.

2. GILLS WHITE OR CREAMY-WHITE-(A) PILEUS OCHREOUS OR UMBER

R. ochroleuca (Gr. ochros, pale yellow; lenkos, whitefrom the usual colour of the pileus). Plate XXXVI. 7 . 
$P \cdot$ 3-4 in., polished, dingy-yellow, pale at maturity, never reddish. $G$. adnexed, rounded, and connected behind, white or pale yellowish. S.2-3 in., stuffed, slightly wrinkled in a reticulated manner; white or lemon yellow at first, becoming pale steel-grey at maturity. Frequent in fir woods in aut.

R. granulosa (from the minutely granular pileus and stem at maturity) differs chiefly in the granular and persistently white stem.

R. fœteus (from the fetid smell).

P. 3-6 in., viscid in damp weather; subglobose at first, becoming expanded and depressed; margin incurved at first, membranaceous, striately ribbed, at length tubercular. $G$. adnexed, crowded, whitish, exuding drops of water when young. S. 2-3 in., very thick, whitish ; stuffed at first, then hollow; frequently eaten out by slugs. Very common in woods, bursting from the ground like a yellowish ball, and then expanding. The var. sub-fatens differs in the more slender stem and thick, distant gills.

\section{(B) PILEUS RED OR PURPLISH}

R. emetica (from its acting as an emetic), "The Sickener." Plate VIII. 5 .

P. 3-4 in., flesh reddish under the separable cuticle, polished; rosy at first, then blood-red, sometimes yellowish, and bleaching with age to almost white or purplish. $G$. almost free, broad, rather distant, clear white. S. 2-3 in., white or tinged red; solid, but spongy within. A showy, gregarious species, common in woods and open places from July to Dec. Abundant in beech-woods in Oct. Some forms are small and fragile, and require to be carefully distinguished from $R$. fragilis, which appears in August in the same localities. In the latter the gills are much more crowded, the pileus thinner and softer, the margin tubercular; and the flesh is always white, never red under the cuticle. 
R. Queletii (after Dr. Lucien Quelet) is much like R. drimeia in stature and colour of pileus, but may be at once known by the persistently white gills.

R. sanguinea, sometimes met with in fir woods, differs from all other species of Russula in the truly decurrent gills. It bears some superficial resemblance to $R$. vibra.

$R$. rosacea, a frequent autumnal species in woods and grassy places, may be distinguished from other species with red or rosy pileus and rosy stem, by the thick, cheesywhite flesh, and persistently white, adnate, broad, crowded gills. The flesh is mild at first, slowly becoming acrid; the gills are usually acrid from the first.

\section{MYCENA}

\section{(Gr. mukes, a fungus)}

A large genus of mostly small species, with long, slender, hollow stems. The margin of the pileus is always straight (a feature which separates it from Collybia), and is more or less stria.te. The gills are adnate or adnexed, never truly decurrent (a feature which separates it from Omphalia and Clitocybe). The majority grow on wood, appearing after storms in summer and autumn. A few common species continue under favourable conditions till Dec. Some contain a coloured milk. They are classified in nine sections, based upon the peculiarities of the stem.

\section{Section I.-Insititiæ}

Stem very slender, dry, neither rooting nor downy, issuing abruptly from the matrix.

\section{Section II.-Basipedes}

Stem dry, not rooting, with a bulbous or swollen hairy base. Usually solitary.

$$
\text { Section III.-Glutinipedes }
$$

Stem distinctly glutinous.

\section{Section IV.-Lactipedes}

Stem dry. Whole plant giving out milk or juice when broken. 


\section{Section V.-Filipedes}

Stem very slender, straight, long, rooting, juiceless, rather tough, not glutinous. Pileus not hygrophanous.

\section{Section VI.-Fragilipedes}

Stem slender, fragile, juiceless; base hairy, not truly swollen; scarcely rooting, not issuing abruptly from the matrix.

\section{Section VII.-Rigidipedes}

Stem firm, rigid, tough, juiceless; base more or less hairy and rooting.

\section{Section VIII.-Adonideæ}

Stem juiceless, not swollen at the base. Brightly coloured, not brownish species. Gills of one colour.

\section{Section IX.-Calodontes}

Stem juiceless, not swollen at the base. Gills always with the edge distinctly darker than the rest, and minutely saw-edged.

\section{SECTION I.-INSITITIÆ}

M. capillaris (capillus, a hair-from the hair-like stem). Plate X. 4 .

$P \cdot \frac{1}{16}$ in., very thin, slightly striate when moist, white. $G$. adnate, few, all of equal length. S. usually I in. (sometimes 2 or 3 in. when growing amongst leaves), weak, and hair-like. Frequent in very wet weather in aut. amongst heaps of dead beech-leaves.

M. corticola (cortex, bark; colo, to inhabit), a common species ( $A u g$. to $D e c$.) occurring in troops amongst moss, etc., on bark of living trees; differs from the preceding in the larger, coloured pileus (shades of black, brown, blue, or grey), and the short stem not exceeding $\mathrm{I}$ in.

\section{Section II.-BASIPEDES}

M. tenerrima (tenervimus, very slender).

$P \cdot \frac{1}{15}$ in., convex, powdered with minute granules. $G$. free, ventricose. $S$. up to I in., minutely hairy, and fixed by 
a minute downy disc. A very delicate, minute, white, gregarious species, occurring on fir-cones, dead branches, twigs, etc., $A$ ug. to Dec. Uncommon.

\section{Section III.-GLUTINIPEDES}

M. vulgaris (vulgaris, common). Plate X. I2.

P. $\frac{1}{4} \frac{1}{2}$ in., almost membranaceous, depressed at maturity, with a minute papillate umbo, viscid, pale brown or greyish, marked with dark lines. G. slightly decurrent, rather broad, white. S. $\frac{3}{4}-\mathrm{I} \frac{1}{2}$ in., slender, viscid, tough, pale. Common amongst pine-leaves and twigs.

M. pelliculosa (from the thin, separable pellicle of the pileus), frequent amongst heather and in heathy fir woods; is larger than the above ( $P$. up to I in.); also differs in the viscid, separable cuticle.

M. epipterygia (from its frequent occurrence on bracken stalks-Ptevis aquilina) -P. $\frac{1}{2}-\frac{3}{4}$ in., S. 2-4 in. - - is a yellowishgreen species, common on branches and twigs in damp places. The pileus and stem are covered with a viscid, easily separable pellicle.

\section{Section IV.-LACTIPEDES}

M. galopoda (Gr. gala, milk; pous, a foot).

$P . \frac{1}{2}$-I in., more or less umbonate, striate; usually blackish at first, then grey; occasionally whitish, with a brown umbo. $G$. adnexed, white or faintly green. S. 2-3 in., slender, rather fragile, greyish-black, base downy and rooting, giving out a copious white milk when broken. Amongst moss on tree-trunks, dead leaves, etc. Common.

M. hæmatopa (Gr. haima, blood; pous, a foot-from the blood-red juice of the stem), appearing in tufts on trunks and stumps in aut., may be easily known by the minutely toothed margin of the pileus ( $\frac{1}{2}-\mathrm{I}$ in.) and the entire white gills. It gives out a dark-red juice when broken. 


\section{SECTION V.-FILIPEDES}

M. vitilis (vitilis, plaited-from the deeply striated pileus).

$P$. $\frac{1}{2}$ in., membranaceous, papillate, deeply striate when moist, brownish, becoming pale. $G$. adnate, rather distant, greyish-white. $S .3^{-6}$ in., long, very slender, equal, shining, juiceless, rooting. A frequent autumnal species amongst leaves in damp places. The deeply striated pileus and the very long weak stem are the chief points of distinction.

The beautiful little M. iris (Gr. ivis, the rainbow-from its tints) belongs to this section. $P \cdot \frac{1}{2}-\frac{2}{3}$ in., bluish, then brownish. G. almost free, tinged grey. S. $1 \frac{1}{2}-3$ in., slender; brownish above, blue below. Tufted or scattered on rotting fir-stumps. Uncommon.

\section{SECIION VI.-FRAGILIPEDES}

M. alcalina (from its alkaline smell).

$P \cdot \frac{1}{2}-1 \frac{1}{2}$ in., deeply striate when moist, shining when dry; colour variable, pallid, yellowish, green, etc. Disc darker. $G$. adnate, rather distant, white, then greyish. S. 2-3 in., slender, equal, pale or yellow, shining, slightly viscid; base downy. Common throughout sum. and aut. in tufts on trunks and stumps or heaps of dead leaves. Smell strong, nitrous.

MI. ammoniaca (from its ammoniacal stem) has exactly the same smell, but is terrestrial; occurring amongst grass. The pileus is slightly striate and umbonate; the stem is never tinged yellow.

\section{SECTION VII.-RIGIDIPEDES}

M. galericulata (galeviculum, a little cap-from the shape of the pileus). Plate XLVI. I.

P. $\frac{2}{3}-2$ in., umbonate, dry, striate up to the umbo; colour variable; brownish, greyish, or pallid. $G$. adnate, whitish at first, then tinged with pink. S. 2-4 in., equal, rigid, pale, tapering to the rooting downy base. Common on trunks 
and stumps (sometimes on leaves), often in densely crowded tufts.

IM. rugosa ( $(n g a$, a wrinkle-from the wrinkled pileus), an equally common species, differs in its solitary habit, tougher substance; short, thicker stem (seldom more than 2 in.), grey gills, and wrinkled, not striated, pileus.

M. polygramma (Gr. polus, many; gramme, a stroke-from the longitudinally striate stem). Plate XLVI. 5.

P. I-I $\frac{1}{2}$ in., conico-campanulate; often becoming expanded; livid brown, paler when dry; margin coarsely striate. $G$. thick, distant, pale grey (often tinged with pink), then whitish. S. 3-4 in., equal, tough, shining; regularly striate throughout its length; pale grey, with rooting strigose base. Common on trunks and stumps in aut. and early win.

\section{SECTION VIII.-ADONIDEA}

M. pura (from its pure colour). Plate VIII. 3.

P. $I \frac{1}{2}-2 \frac{1}{2}$ in., obtusely umbonate, glabrous ; margin striate; colour usually pale rose, also lilac, greyish, or pallid. $G$. adnexed, broadly sinuate behind, connected by veins, very broad; pale, then reddish. S.2-3 in., rigid, whitish, or the colour of the pileus; base downy. A very common species in woods, hedges, and fields. At once known by the strong radishy smell and taste, and the broad gills connected by veins. Gregarious. Sometimes attacked by the mould Mucor macrocarpus.

M. lactea (lac, mill--from the colour) is a small white species of scattered habit. $P$. not exceeding $\frac{1}{2}$ in., and usually with a yellow tinge at the disc. Commonly seen in fir woods in early aut.

\section{SECTION IX.-CALODONTES}

M. elegans (elegans, neat) is, perhaps, the most frequent representative of this section. $P \cdot \frac{1}{2}-\frac{3}{4}$ in., brown or yellowish. $G$. greyish, with darker saffron-colour margin. S. 2 in., 
slender, livid, with downy base. A gregarious species, frequent in pine woods. Very distinct in the saffroncoloured margin of the gills.

\section{COLLYBIA}

(Gr. kolmbos, a small coin-from the frequently small and regularly formed pileus)

C. radicata (vadix, a root-from the rooting stem), "Longrooted Agaric." Plate XLVI. 3.

P. I $\frac{1}{2}-4$ in., glutinous, radiately wrinkled; colour variable, olivaceous, ochreous - brown, etc.; rarely quite white. $G$. adnexed, often with a decurrent tooth, rather thick, distant, white. S. 4-8 in., very slender, twisted, paler than the pileus, striately grooved (more or less), polished, somewhat hollow, ending in a deeply penetrating (sometimes 6-8 in.) fusiform root. Common during sum. and aut. in woods, and under trees in fields and hedges.

C. longipes (longus, long; pes, a foot-from the long stem), a somewhat smaller species than the above, may be easily distinguished by the dry velvety pileus and stem.

C. fusipes (fusus, a spindle; pes, a foot-from the spindleshaped stem), "Spindle-shank." Plate XLVI. 7.

P. I $\frac{1}{2}-2 \frac{1}{2}$ in., hemispherical, then expanded; glabrous, dry, reddish-bay, becoming tan colour and more or less cracked when old. $G$. adnexed at first, soon becoming free, broad, distant, connected by veins, crisped; whitish, then pale umber. "They have a rather watery appearance, though dry, like that of a piece of half-dry parchment." $S .3 .6$ in., up to $I$ in. thick, swollen in the centre and tapering to both ends (spindle-shaped). Often twisted, grooved longitudinally, reddish-brown; base rooting ; stuffed at first, then hollow. Outer coat remarkably cartilaginous. Growing in dense tufts on or near old stumps in woods, etc. Common throughout sum. and aut. 


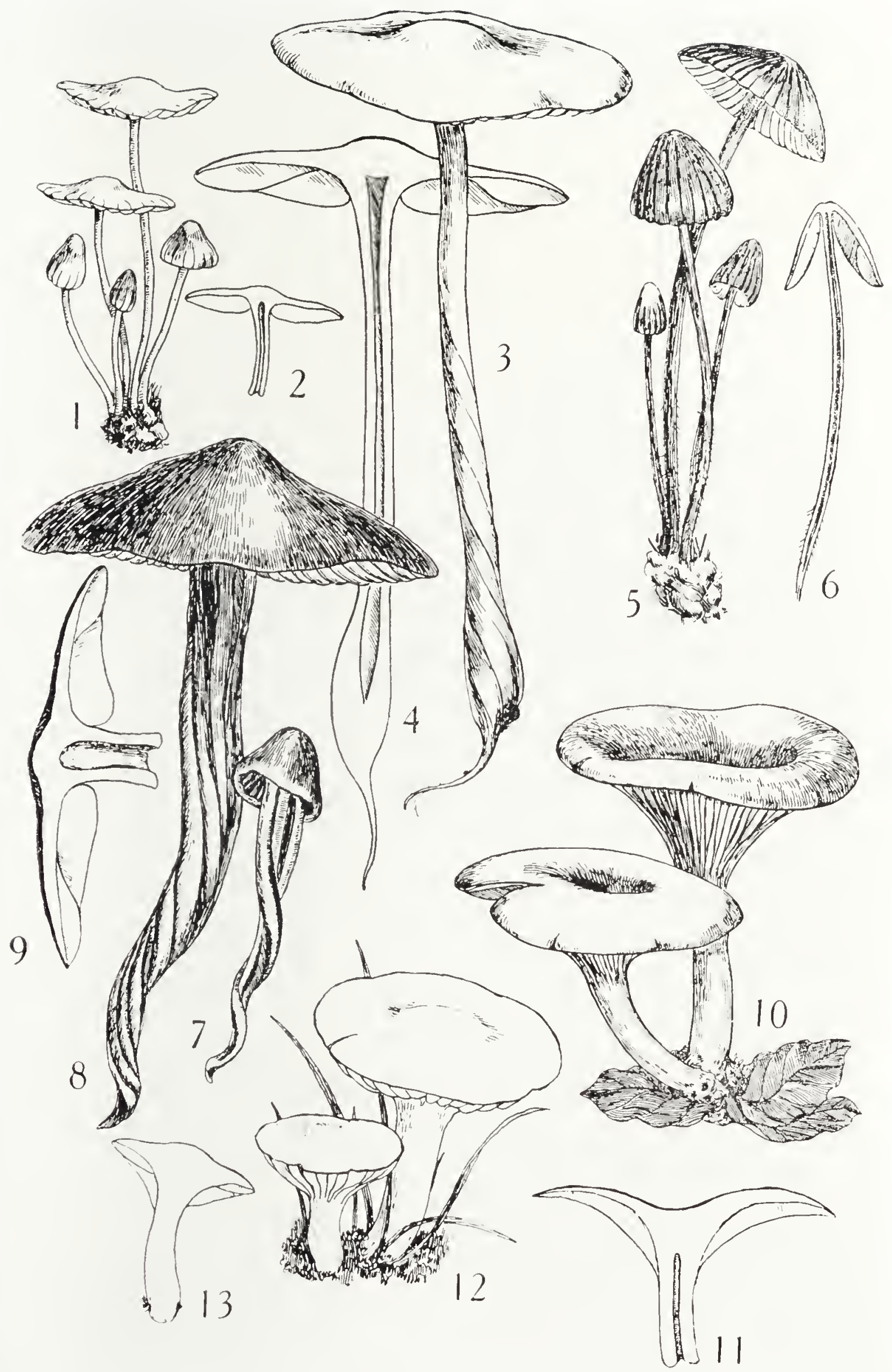




\section{DESCRIPTION OF PLATE XLVI}

WHITE-SIORED AGARICS (LEUCOSPORAE)-II

FIG. I.-My'ena galericulata.

FIG. 2.-Ditto: section showing the adnate gills and hollow stem.

Fig. 3.-Collybia vadicatu.

FIG. 4--Ditto: section showing the adnexed gills and hollow rooting stem.

FIG. 5.- Mycena polysramma.

FIG. 6.-Ditto: section of an unexpanded plant.

FIG. 7.-Collybia fusites, young.

Fig. 8.-Ditto, mature.

FIG. 9.-Ditto, showing the hollow stem and broad gills.

Fig. Io.-Clitocybe flaccida.

FIG. Ir.-Ditto: section showing the decurrent narrow gills.

FIG. I2.-Hygrophorils iriginens, young and mature plants.

FIG. I3.-Ditto: section showing the decurrent gills. 
C. lancipes (lancea, a spear; pes, a foot-from the supposed resemblance of a longitudinal section of the stem to a spear blade) differs in its rigidity, solitary habit, and the radiately wrinkled pileus.

C. maculata (macula, a spot-from the foxy stains).

P. 2-5 in., margin thin, incurved at first, firm, fleshy, white, then more or less blotched reddish-brown. $G$. emarginate, almost free, closely crowded, narrow, white, then pallid. S. 3-4 in., up to $\frac{3}{4}$ in., thick, striated or channelled, attenuated downwards and rooting, fibrous externally, stuffed or hollow. The var. immaculatus has broader and serrated gills, and does not become spotted. Common in sum. and ant. in and about woods (chiefly pine) on sandy soils.

C. butyracea (butymu, butter-the pileus being buttery to the touch). Plate VII. 9 .

P. I $\frac{1}{2}-3$ in., somewhat hygrophanous, convex, then expanded; umbonate, shining as if oiled; colour variable. "Of a livid ochre or dull green; when quite young lividbrown; the margin subrufescent, but a portion below the umbo soon grows pale, so that the pileus appears of four colours. The umbo is always dark, but sometimes the rest of the pileus is pale rufescent or ochreous; margin occasionally striate, flesh white, mottled with rufous" (Berkeley). $G$. slightly adnexed, free; white, never spotted nor stained. S. $2 \cdot 3$ in., attenuated upwards, more than $\frac{1}{2}$ in., thick and downy below; striated, reddish, stuffed or hollow; cartilaginous outside. Very common in fir woods, usually in troops thronghout the year in sheltered situations, also occurring in mixed woods, by roadsides, etc.

C. velutipes (vellus, fleece; pes, a foot-from the velvety stem), "Velvet Stem." Plate I. I.

P. I-3 in., smooth, slimy, bright yellow with darker disc, often altogether fulvous. $G$. adnexed, broad, ochreous. S. 2-4 in., usually incurved, velvety, rich dark brown, pale 
above. Tufted, on trunks, logs, etc., in aut. and win. Very frequent on dead gorse stems. Abundantly distinctive in the viscid reddish-yellow pileus and beautiful velvety stem. Remarkable in enduring extremes of temperature, being one of the few agarics that flourish in win. It sometimes springs from a golden byssoid mycelium.

C. conigena (coms, a cone; giguo, to bear-from its habitat). Plate X. I4.

$P \cdot \frac{1}{2}$-I in., glabrous, umbonate; often unequal and angular ; yellowish brick-red, pale when dry. G. slightly adnexed, then free, very crowded, pallid. S. I-3 in., very slender, tough, hollow; covered at first with a white powder, then the colour of the pileus, ending in a very long, hairy, rooting base. Common in pine woods, Sept. to Dec., amongst leaves; often on cones; usually gregarious.

C. cirrhata (cirnus, a curl-from the twisted base of the stem) differs chiefly in the adnate gills. It is usually smaller, and occurs generally on blackened decaying agarics.

C. tuberosa (from the tuberous base of the stem). Plate IV.7.

$P$. up to I in., umbonate, almost glabrous, white. $G$. adnate, crowded, unequal, white. $S$. $\frac{1}{2}-1 \frac{1}{2}$ in., white, rarely tinged with red. A tough, firm, gregarious species, which may be found in similar situations as the preceding, which it superficially resembles, but is easily known by the glabrous base of the stem, and in springing from a smooth, solid, yellowish-red sclerotium.

C. esculenta (from its edible qualities). Plate VII. I2.

$P \cdot \frac{1}{2}-\frac{3}{4}$ in., convex, then plane, glabrous, even, sometimes slightly striate when old, ochreous tan or brownish. $F$. reddish. $G$. adnexed, seceding from the stem, very broad lax, rather distant, whitish, or tinged tan colour. S. I-2 in., very slender, tough, straight, somewhat hollow, even, glabrous, yellowish-tan, ending in a long rooting base (up to 6 in.), which is usually glabrous, but downy when growing 
amongst leaves. Gregarious in woods and pastures in spv. Common. Often growing on fir-cones. The Nagelschwamme of the Austrian markets.

C. tenacella (tcnax, tough-from its tough substance). Plate X. Io.

P. $\frac{1}{2}-\frac{2}{3}$ in., orbicular, slightly umbonate, glabrous; brown at first, then pale. $F$. thin, white. $G$. adnexed, emarginate, broad, rather distant, usually pure white. S. 2-4 in., very slender, equal, straight, glabrous, white, ending in a long downy, rooting base. Common in woods, especially pine, in spr. and aut. A tough little species, usually solitary, but sometimes in troops.

C. macilenta (macies, leanness) may be at once recognised by the yellow colour of the entire plant.

C. dryophila (Gr. drus, oak ; philos, loving). Plate VIII. I.

P. I-3 in., convex, then plane; margin incurved at first, then expanded; centre usually depressed; colour variable, reddish-bay to pale tan. G. almost free, but sometimes appearing as if adnexed, crowded, narrow; white or very pale flesh colour. S. I-3 in., $\frac{1}{4}-\frac{1}{3}$ in. thick, yellowish or reddish, cartilaginous, hollow. A fragile species, common in spr. and aut. on the ground and on rotten stumps in woods. Solitary or more or less gregarious. Poisonous.

\section{MARASMIUS}

(Gr. maraino, to shrivel or wither-from the habit, drying up, not becoming putrid)

M. peronatus (pero, a lind of boot-the stem being more or less covered with strigose down). Plate VIII. 7.

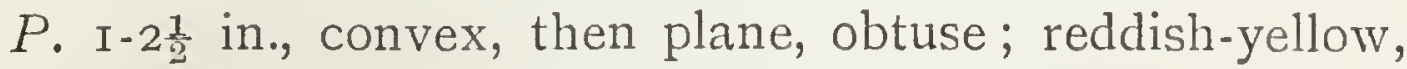
then tan-colour. $F$. pliant and thin. $G$. adnexed, then free, colour of the pileus; margin yellowish. S. 2-3 in., slender, fibrous, whitish, densely covered, except at the apex, with 
coarse yellow down. Taste very acrid. Very common amongst leaves in woods in sum. and ant. Gregarious.

M. urens (uvo, to burn-from its taste), a closely allied species. Differs chiefly in the white down at the base of the stem only. It bears a superficial resemblance to Marasmins oreades.

M. oreades (Gr. oveias, a mountain nymph-from its growing in fairy rings), "Fairy Ring Champignon." Plate IX. 3.

$P$. I-2 in., hemispherical, then plano-convex, somewhat umbonate; watery brown at first, then dry and tan colour. $G$. free, distant, yellowish-white. $S$. $I_{\frac{2}{2}}-2$ in., slender, solid, whitish, tough, fibrous, usually completely covered with down, especially at the base. Very common in pastures in sum. and ant. Edible.

M. ramealis (vamus, a branch - from its habitat). Plate X. I.

$P$. less than $\frac{1}{2}$ in., obtuse, wrinkled, not striate; white, disc reddish. $G$. adnate, distant, white or reddish. S. not exceeding $\frac{1}{2}$ in., very slender, white, base reddish. $M$. anadelphus (Gr. an, together; adelphos, a brother-from its close relationship to the preceding) differs in the reddish-yellow pileus with striate margin. $M$. candidus (candidus, shining white) is thinner and entirely white. These are three little species occurring gregariously on decaying twigs, especially bramble and hazel, in ant. $M$. ramealis is by far the commonest.

M. androsaceus (the derivation of this worc is uncertain). Plate X. 9.

$P$. up to $\frac{1}{2}$ in., dry, membranaceous, striate, pale rufous. $G$. adnate, distinct, distant, pallid. $S$. I- $2 \frac{1}{2}$ in., entirely black, shining, very thin, almost thread-like, tough, horny, twisted and striate when dry. Common on leaves and twigs throughout the year. Gregarious. Especially abundant in fir plantations. 
M. rotula (vota, a wheel-from the resemblance of the pileus to a little wheel when viewed from below), "Little Wheel." Plate XXXV. 8.

It is a small species ${ }^{\circ}$ with shining black stem, common on fallen twigs, and is abundantly distinct in having the broad distant gills joined behind to a collar which is quite free from the stem. It is entirely whitish, with plicate pileus. There is usually a cord-like mycelium present.

M. graminum (gramen, grass-from the habitat) is also provided with a collar, but may be distinguished by the pale-red sulcate pileus, and in growing on grass. Uncommon.

M. Hudsoni (after William Hudson, author of "Flora Anglica"). Plate X. 7 .

$P$. very minute, only $\mathrm{I}-2$ lines across, very thin, brownish, covered with long spreading purplish hairs. G. adnexed, white. S. $\frac{1}{y}$-I in., slender, colour of the pileus, and, like it, adorned with long purplish hairs. On fallen holly leaves sum. and aut. Frequent in England, rare in Scotland.

M. epiphyllus (Gr. epi, upon; phullon, a leaf-from the habitat). Plate X.6.

$P$. up to $\frac{1}{2}$ in., plane, then umbilicate, wrinkled, very thin, milk-white. G. adnate, few, veined, white. S. I-2 in., very slender, horny, brown or blackish, apex pale, minutely velvety. A common autumnal species. Gregarious on fallen leaves, twigs, etc.

\section{TRICHOLOMA}

(Gr. thix, a hair; loma, a fringe-from the hairy or silky covering of the pileus, well seen in young specimens)

The chief characteristics of this genus are the sinuate gills and the symmetrical, never truly umbilicate, pileus. Collybia differs in the externally cartilaginous, not fibrous, stem. In Clitocybe the gills are never sinuate, but gradually 
narrow behind. Certain species of Pleurotus somewhat resemble it, but differ in growing on wood. All the species are fleshy and robust, terrestrial, and for the most part autumnal. They are usually classified in two series, comprising seven sections, as follows :

\section{Series A.--Pileus viscid, SCaly, or Downy}

\section{Section I.--Limacina}

Pileus viscid in wet weather; downy or somewhat scaly (not torn into scales); not hygrophanous.

\section{Section II.-Genuina}

Pileus not viscid; torn into scales or fibrillose.

\section{Section III.-Rigida}

Pellicle of the pileus rigid, granular, or broken up into glabrous fragments when dry.

\section{Section IV.-Sericella}

Pileus silky at first, soon becoming glabrous; quite dry.

Series B.-Pileus even, glabrous, neither downy, scaly, NOR VISCID

\section{Section V.-Guttata}

Pileus fleshy, soft, fragile, with drop-like spots; stem solid.

\section{Section VI.--Spongiosa}

Pileus compact, then spongy, obtuse, even, glabrous; not hygrophanous.

\section{Section VII.-Hygrophana}

Pileus thin, subumbonate, hygrophanous.

\section{SECTION I.-LIMACINA}

T. resplendens (from its bright shining appearance).

P. 2-4 in., silvery, shining white, sometimes with yellowish, silky disc. $G$. almost free at first, then very emarginate. S. 2-3 in., stout, equal or bulbous, dry. Frequent in beech and other woods in aut. Gregarious, clear white, resembling Hygrophorus ebumens in habit. 
T. flavobrunneum (Aavus, light yellow; brumens, brown). P. 3-6 in., with thick, clear yellow flesh, reddish-brown, usually with darker disc, innately minutely silky. G. crowded, pale yellow, becoming brown with age and when touched. S. 3-5 in., stout, reddish-brown, generally narrowed at each end, hollow. Frequent in deciduous woods, gregarious, often tufted. Smell strong, resembling that of new meal.

T. albobrunneum (albus, white; bvamncus, brown), of frequent occurrence in fir woods. Differs from the preceding in the absence of smell, and persistently white flesh.

\section{SECTION II.-GENUINA}

T. rutilans (vutilo, to be reddish). Plate VII. 7.

P. 3-6 in., with thick, deep-yellow flesh, margin at first incurved, covered with purplish or reddish-brown down at first; often umbonate. At maturity the cuticle is broken up into small scales, yellow, variegated with purple. G. yellow, broadly adnexed, edge deep yellow. S. 2-3 in., stout, imperfectly hollow, yellow, more or less variegated with purplish scales. A very showy and common inhabitant of pine woods.

T. terreum (tevra, the earth-from its earthy colour). Plate VIII. 9.

P. 2-3 in., dark bluish-grey, sometimes brownish, with innate, downy scales. $G$. cut out behind and adnexed; margin crenulate. S. I-3 in., stout, whitish. Common in fir and beech woods. Solitary or tufted. The var. ovinubens has the edge of the gills, also the stem, reddish or rose colour, and smells like new meal.

\section{SECTION III.-RIGIDA}

T. saponaceum (from its soapy odour).

P. 2-4 in., dry, glabrous, livid brown or tinged olive, cracked into scales at maturity. $F$. reddish when broken. G. distant, white, then tinged greenish. S.2-4 in., whitish, 
solid. Common in woods. A firm, compact species, with a peculiar strong soapy smell.

T. virgatum (virga, a stripe-from the streaked pileus).

$P$. 2-3 in., somewhat umbonate, greyish, streaked with minute black lines; always very dry. $F$. greyish-white. $G$. broadly emarginate, greyish. S. $2-3 \frac{1}{2}$ in., stout, whitish inside and outside. Usually solitary. Common in pine and other woods.

\section{Section IV.-SERICELLA}

T. sulphureum (from its sulphur colour). Plate XLIV. I.

P. I-3 in. G. distant. S. 2-4 in. Gregarious. Common in woods and hedgebanks in late sum. and aut. Abundantly distinctive in the sulphur-yellow colour of every part and the strong smell of gas-tar. Very young plants have a somewhat mealy smell.

T. inamænum (inamamus, unpleasant) smells even stronger than the preceding. Frequent in pine woods. Our only white Tricholoma with a strong smell.

T. lascivum (lascivus, playful, wanton-from its many affinities), a frequent inhabitant of mixed woods; is allied to both the preceding, but differs in the crowded gills and the tan-colour pileus, which becomes pale at maturity.

\section{SECTION V.-GUTTATA}

T. gambosum (gamba, a hoof-from the hoof-like pileus), "St. George Mushroom." Plate IX. I3.

$P$. 3-5 in., margin, incurved and downy at first, pallid tan, becoming cracked. $F$. thick, soft, white. $G$. enarginate, sinuate, and decurrent when old; crowded, white. S. $2-2 \frac{1}{2}$ in., up to I in. thick, equal, white, solid. In pastures in spr. and sum., often growing in large circles. Smell pleasant, like new meal. Frequent. Edible. Much esteemed in France. Worthington Smith says it is fit for any saint in the calendar. 


\section{SECTION VI.-SPONGIOSA}

T. album (albus, white).

Whole plant ivory white, with weak smell and bitter taste.

P. 3-4 in., fleshy, very dry, disc sometimes yellowish. G. emarginate, crowded, persistently, white. S. 3 in., stout, attenuated upwards, elastic, solid. Frequent in woods in aut. Sometimes very slender.

T. personatum (persona, a mask-from its mask, the downy margin of the pileus and the scaly stem, as contrasted with its ally, T. mudum).

P. 2-4 in., margin at first incurved and downy, slightly projecting beyond the gills; yellowish tan colour or greyishlilac. $G$. rounded behind, almost free, crowded, violet at first, then dingy. S. 2-3 in., $\frac{3}{4}$ in. thick, rather bulbous, downy, solid, colour of the pileus or tinged violet. In pastures and woods in sum. and aut., often in large rings. Smell pleasant, recalling that of Marasmius oveades. At one time sold in the market at Covent Garden under the name of "Blewitts."

T. nudum (from the naked edge of the pileus and the smooth stem) is more slender than the preceding. $F$. very thin, except at the disc. Whole plant beautiful violet colour at first, becoming rufescent, the gills darker. Margin persistently incurved and not downy. Smell, acid.

\section{SECTION VII. - HYGROPHANA}

T. grammopodium (Gr. gramme, a line ; pous, a foot-from the striate stem).

$P$. 3-6 in., margin thin, brownish at first, whitish when dry, soft, fragile, obtusely umbonate. $G$. closely crowded, white, adnate upon the expansion of the pileus. S. 3-4 in., $\frac{1}{2}$ inch thick, distinctly grooved longitudinally, whitish, solid, elastic. Often growing in rings in pastures and 
grassy woods in sum. and aut. A large, lax, umbonate species, abundantly distinctive in the grooved stem and crowded gills.

\section{ARMILLARIA \\ (Avmilla, a ring-from the ringed stem)}

A. mellea (mel, honey-from the honey-coloured pileus), "Honey Agaric." Plate XIII. I.

P. 2-5 in., often dark or covered with olive down when young, becoming paler, usually honey colour, sprinkled with small blackish-brown scales; margin striate. G. adnate, then more or less decurrent, rather distant, white at first, then brownish; powdered at maturity with the copious white spores. S. 3-5 in., robust, more or less grooved, dingy ochreous; base often covered with yellowish down, stuffed, then hollow. $R$. large, tumid. One of the commonest of our autumnal fungi, growing in dense tufts at the base of stumps and living trees. Sometimes solitary. Smell strong, unpleasant. A remarliably variable species. Greville wrote of it: "There is scarcely a plant more apt to assume different aspects under different conditions than the present one, and yet, to an experienced eye, there is always a peculiarity about it, not easily expressed in words, which is sufficient to distinguish it."

A. mucida (from the slimy pileus), "Slimy Beech Agaric." Plate XIII. 3 .

$P . \quad I \frac{1}{2}-3$ in., obtuse, often wrinkled, very glutinous, usually shining white, but sometimes olive-brown or even sooty. $F$. very thin, almost diaphanous. $G$. broadly adnexed, distant, white. $S$. $I \frac{1}{2}-4$ in., slender, ascending, glabrous, white, often with blackish scales at the base. $R$. near the apex of the stem, large, white. Solitary or cæspitose. Frequent on beech. Typical specimens are easily distinguished by the shining white of every part, the glutinous pileus, and ample ring. 


\section{LEPIOTA}

(Gr. lepis, a scale-from the scaly pileus and stem)

L. procera (proceva, tall), "Parasol." Plate XV. I.

P. 4-9 in., cylindrically ovate at first, expanded at maturity, with a broad and prominent umbo ; cuticle brown, broken up into broad flat scales, their interstices whitish. $F$. rather thick, tough, always white. G. quite free from the stem, crowded, whitish. S. 5-8 in., $\frac{1}{2}$ in. thick, hollow, swollen below, firm, somewhat cartilaginous, blotched with brown scales, inserted into the flesh of the pileus as into a socket, from which it may be detached and replaced. $R$. large, persistent, at maturity becoming free and slipping down the stem. Common in sum. and aut. in open pastures, etc.; usually in troops or in rings. Smell, pleasant. It makes good ketchup.

L. rachodes (Gr.vakos, a ragged garment-from the ragged pileus) differs from the above in the perfectly even, not at all scaly, stem, and the thicker white flesh of the pileus, which becomes tinged red when broken. Chiefly under firs.

L. Friesii (after Elias Fries) differs from L. proceva in the fixed ring and smaller tomentose scales of the pileus.

L. prominens (from the prominent umbo) is very distinct in the remarkably prominent umbo and abruptly bulbous stem.

I. Badhami (after C. D. Badham) occurs usually under yews and in hedges; distinctive in the saffron-red flesh when bruised. $P$. minutely scaly.

L. emplastrum (from the plaster-like scales) also becomes red when bruised, but differs from L. Badhami in the glabrous pileus becoming broken up into large irregular persistent patches.

L. cristata (from the scaly-crested pileus). Plate XXXVI. I. 
P. $\frac{3}{4}$-I $\frac{1}{2}$ in., cuticle continuous at first, becoming broken up into reddish-brown scales, usually arranged in a concentric manner; ground colour, whitish, and minutely silky. $G$. free, then remote, pallid. S. $2-2 \frac{1}{2}$ in., smooth, whitish, or tinged brown. $R$. distant, soon falling away. A common autumnal species in fields, lawns, and gardens; of scattered habit, with strong smell and taste.

L. clypeolaria (clypeus, a shield-from the shape of the pileus) may be known from the above by the scaly stem, gills very close to the stem, and the very weak smell. Uncommon.

L. gramulosa (from the granular pileus).

P. $\frac{2}{3}$ - I in., obtusely umbonate, scurfy, brownish or nearly white; margin often fringed with the remains of the veil. $F$. reddish. $G$. slightly adnexed, crowded, broad, white. S. I-2 $\frac{1}{2}$ in., equal, smooth, pale, stuffed, then hollow. A somewhat gregarious species; very common in sum. and aut. in woods and on heaths.

L. carcharias (Gr. kavchavias - from a fancied resemblance in the granules of the pileus to the teeth of a dog-fish), of frequent occurrence under firs, may be known from the preceding by the strong smell and bitter taste.

L. amianthina (Gr. amiantos, undefiled-from its pure colour) differs from L. gramulosa in the adnate gills and yellow flesh, especially of the stem. An uncommon species.

\section{AMANITOPSIS}

(From its relationship to Amanita)

A. vaginata (vagina, a sheath-from the volva). Plate XXXVI. 3 .

P. 2-5 in., rarely with fragments of the volva attached, shining when dry, margin membranaceous and coarsely striate, colour variable. G. free, not much crowded, white 
or pallid. S. 4-5 in., slender, attenuated upwards, soft, fragile, more or less hollow; the surface broken up into squamules; white. $V$. free from the stem, except at the base, sheathing, fragile, almost completely buried in the ground, brownish. Very common amongst grass in woods and by roadsides, etc., from June to Nov. Usually solitary. Persoon divided vaginata into two distinct species: the grey form (livida), and the brown one (spadicea). One appears earlier in the season than the other. Dr. Plowright remarks (Brit. Mycol. Soc. Trans., vol. i., p. 40) that, in addition to the above differences, "in the reddish-brown form (spadicea) there is a second volva inside the outer; in the grey form (livida) there are folds or wrinkles of considerable size in the inner surface of the volva." There is also a pure white form, Greville's Agaricus nivalis.

\section{AMANITA}

(Galen's name for certain fungi)

A. mappa (mappa, a napkin-from the appearance of the volva). Plate XXXVI. 5.

P. 2-3 in., dry, usually white or yellowish, with broad irregular scales. G. adnexed, crowded, narrow, clear white. $S .2-3$ in., white. R. superior, lax, usually torn. $V$. splitting regularly; base globosely bulbous; margin acute and distinct. A strong-smelling, very poisonous species frequent in woods in ant.

A. phalloides (from the volva, as in the Phalloidaceæ), "Death-cup " or "Destroying Angel." Plate XVI. 8.

P. 3-4 in., viscid when moist, but not truly glutinous; sometimes with fragment of the volva adhering to the shining greenish-yellow or olive surface. $F$. thick, white. $G$. free, numerous, unequal, pure white. $S \cdot 3-5$ in., up to $\frac{2}{3}$ in. thick, almost glabrous, white, bulbous, solid at the 
base, slightly attenuated upwards and hollow. $R$. large, reflexed, slightly striate, entire, white. $V$. more or less buried in the ground, bulbous, nearly free, with torn, lax margin. A very common species in woods, appearing in early spv., and continuing till the arrival of the frosts of late ant. The smell is unpleasant, but not strong until the plant has attained maturity. This is the species so frequently mistalken for the edible mushroom, always with fatal results. The two species are not at all alike at maturity, but in the young state Amanita phalloides might be mistaken for a "button" mushroom. It usually occurs in woods, but I have frequently seen it near trees and hedges in fields, growing in close proximity to A gavicus campestris. One of the most deadly of fungi contains the poison known as phalline (see note on p. 36).

A: muscaria (musca, a fly-from its former use as a fly poison), "Fly Agaric."

P. 4-8 in., margin striate, usually deep scarlet (sometimes orange, lemon-yellow, or brownish), adorned with white or yellowish warts, the remains of the volva. The warts are frequently washed off in wet weather. $G$. approaching the stem, and forming decurrent lines down it, numerous, white or tinged yellow. S. 4-7 in., up to I in thick, ovately bulbous below, stuffed, then hollow, whitish. $R$. lax, ample, white. $V$. adnate, broken up into concentric scales. Common in woods of birch and fir from July to Nov. Gregarious. Very poisonous; contains amanitine. Very handsome, probably receiving more admiration than any other species of our native agarics.

A. rubescens (from the flesh becoming reddish when broken), "The Blusher." Plate XLIV. 7.

P. 3-5 in., reddish-brown or tan colour, sprinkled with small adnate warts, which are often washed off in very wet weather. $F$. thick, white, becoming reddish when broken. $G$. narrowed behind and touching the stem, passing down 
it in decurrent lines. S. 3 in., up to I in. thick at the base, attenuated upwards, stuffed, more or less scaly, whitish, then stained red, flesh red with age or when bruised. $R$. large entire, striate, drooping. $V$. almost absent; the bulbous base of the stem is more or less concentrically grooved. A common woodland species in sum. and aut. Variable, but very distinctive in the red colour of the flesh when bruised.

A. spissa (spissus, crowded-from the small, crowded warts) comes near to the above, but the flesh is persistently white; the pileus umber, grey or sooty.

A. nitida (nitidus, shining-from the shining pileus) may be easily recognised by the shining, whitish pileus, carrying large, thick, brownish, angular warts.

\section{Order ASCOMYCETES}

It is quite impossible to consider in detail the numerous families and genera comprised in this Order. The majority of species are small, and cannot be accurately determined without the aid of the microscope. Some of the most conspicuous and (chiefly) common species are delineated on Plates XLVII. and XLVIII. The following notes for the most part concern these.

\section{Sub-order DISCOMYCETES}

(See p. I4)

Peziza (Lachnea) hemispherica, "Hairy Blue Elf-cup." Plate XVI. 2.

Asc. $\frac{1}{4-\frac{3}{4}}$ in., stalkless; globose at first; at maturity plane, or almost so; the margin slightly raised or turned back, sometimes wavy. Exterior dingy brown, covered with long spreading brown hairs, arranged in small clusters. Disc bluish-white. Frequent in hedges and shady places in aut., scattered or gregarious, superficial or more or less buried in the soil. Easily recognised by the bluish-white disc. 
Peziza (Geopyxis) coccinea, "Scarlet Elf-cup." Plate XVIII. 4 .

Asc. $\frac{3}{4}-\mathrm{I} \frac{1}{2}$ in., stalked; closed at first, forming a very shallow cup at maturity. Exterior whitish or reddish, delicately hairy. $S$. whitish, tomentose, of variable length. Disc a beautiful deep carmine or rose-red. On rotten trunks in win. and early spr., frequent. Sold in Somerset and Yorkshire with moss for decorative purposes. There is a var. albida with cream-coloured disc.

Peziza vesiculosa, "Bladder Elf-cup." Plate XLVII. 9. Asc. $\frac{1}{2}-3 \frac{1}{2}$ in., usually sessile; sometimes narrowed into an elongated stem-like base; margin more or less incurved and notched. Exterior brownish and coarsely granular. Disc pale brown. Substance brittle. Common on rich soil, rotten leaves, etc., in sum. and aut.; clustered, often distorted from mutual pressure.

Peziza bufonia, "Toad-like Elf-cup" $\left(\frac{3}{4}-I_{\frac{1}{2}}\right.$ in.), which frequents rubbish-heaps and damp places, differs from the preceding in the dark-brown disc and warted exterior.

Peziza venosa, "Scented Elf-cup." Plate XLVIII. 5.

Asc. I-2 in., sessile, or with a short, stout, stem-like base; margin incurved at first, more or less split, lobed and waved at maturity. Exterior whitish and minutely granular. Disc umber-brown, marked with anastomosing ribs radiating from the base. Terrestrial, appearing in spr. Easily known by the strong nitrous smell.

Peziza badia, "Common Brown Elf-cup." Plate XLVII. 5 .

Asc. I-2 in., sessile or narrowed into a very short, stout, stem-like base; often more or less lacunose; globose, then cup-shaped, with even margin; cup often wavy. Exterior pale brown, often with a purplish tinge, minutely granular. Disc dark brown. Common on the ground amongst grass by roadsides, and on moors and heaths, sum. and aut. Gregarious or tufted. 

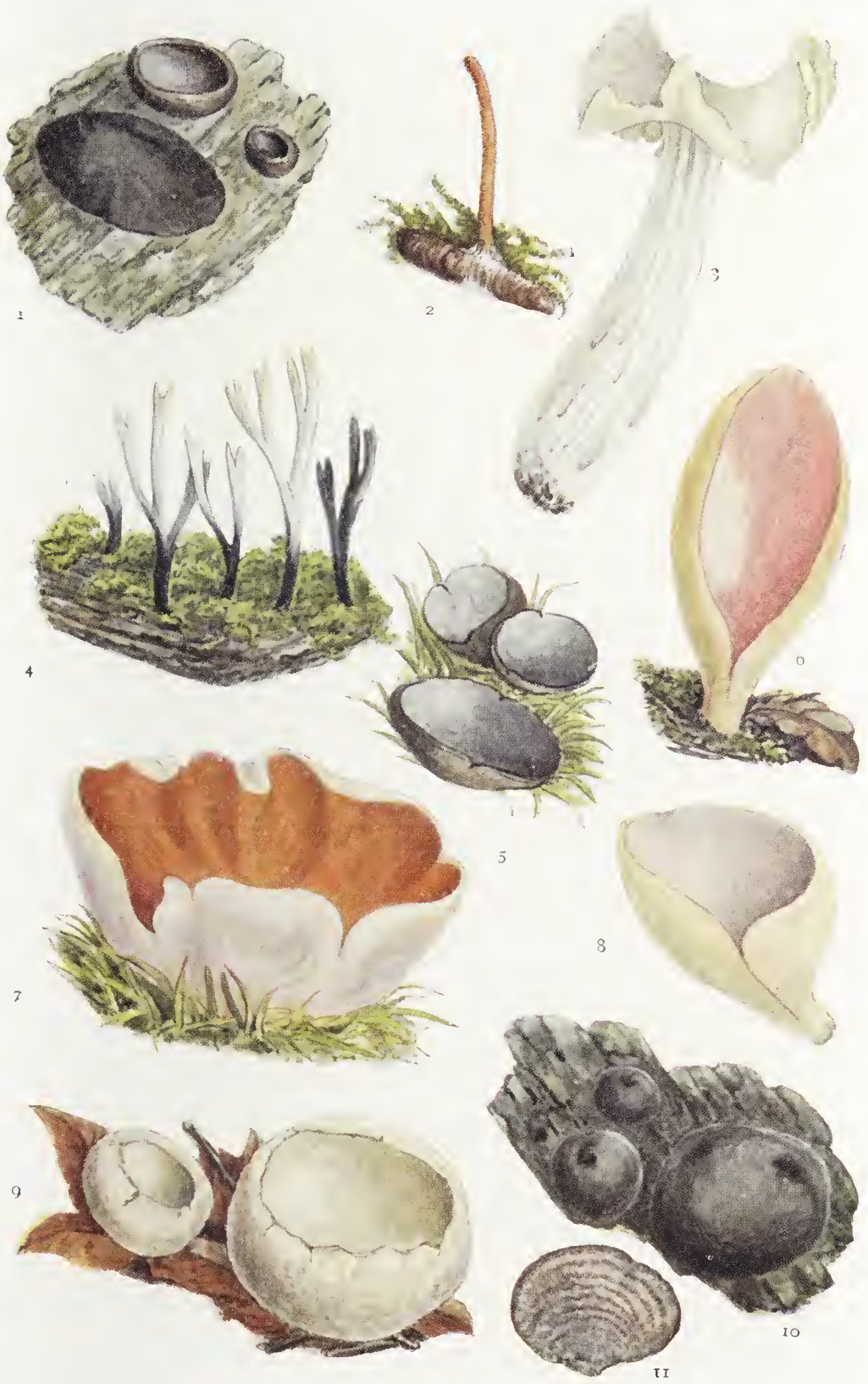

SOME FAMILIAR ASCOMYCETES 


\section{DESCRIPTION OF PLATE XLVII}

\section{SOME FAMILIAR ASCOMYCETES}

FIG. I.-Bulgaria polymorpha: plants in various stages of growth.

FIG. 2.-Cordyceps milltaris growing on the pupa of a moth.

FIG. 3.-Helvella crispa.

FIG. 4.-Xylaria hypoxylon.

Fig. 5.-Peziza badia. (One-quarter natural size.)

FIG. 6.-Peziza (Otidea) onotica.

FIg. 7.-Peziza (Otidea) aurantia.

FIG. 8.-Peziza (Otidea) leporina.

FIg. 9.-Peziza vesiculosa, young and mature.

FIG. IO.-Daldinia concentrica: plants of various ages.

FIG. II.-Ditto: section showing the concentrically zoned interior. 
Peziza (Otidea) leporina, "Bat's-ear Elf-cup." Plate XLVII. 8.

Asc. $\frac{3}{4} \cdot 3$ in., high and broad; divided to the base on one side, with a short stem-like base; margin usually involute. Exterior pale ochre, disc darker ; " throughout of a sober tan colour, resembling common wash-leather used for cleaning plate." Gregarious in aut.amongst leaves and moss in woods.

Peziza (Otidea) onotica, "Hare's-ear Elf-cup." Plate XLVII. 6.

Asc. I- $3 \frac{1}{4}$ in. high, up to 2 in. diam.; usually elongated ear-shaped, but sometimes almost equal and entire; narrowed into a wrinkled stem-like base. Exterior pale tawny orange. Disc pale orange, with a rosy tinge. Amongst leaves in woods in sum. and aut. Uncommon.

Peziza (Otidea) aurantia, "Orange-peel Elf-cup." Plate XLVII. 7.

Asc.. I-3 in.; usually tufted and irregular, with split and raised margin; solitary specimens circular and even. Exterior pale orange, downy. Disc bright orange or orangered, sometimes much paler. Thin and brittle, usually spread flat on the ground at maturity. Frequent in aut. It is common around Haslemere on newly-made roads of local sandstone, appearing the aut. after the road is made, persistíng for two, three, or rarely four years, and then completely disappearing. I have never observed it in any of the numerous sandstone quarries in the district.

Peziza (Acetabula) vulgaris, "The Chalice." Plate XVI. 4. Asc. I-2 in., with a distinct, stout, imperfectly hollow stem, covered with raised ribs. Mouth somewhat contracted. Exterior pale umber; minutely scurfy, with branching veins. Disc dark umber-brown. A tough, solitary species, appearing in spr. in shady places. Easily recognised by the fluted stem and veined outside. A mould, Hypomyces cervimus, sometimes attacks the disc, causing it to appear as if dusted with brown powder. 
Helvella crispa, "Common Helvel." Plate XLVII. 3. Asc. $I \frac{1}{2}-2 \frac{1}{2}$ in. in diam.; margin wavy, adhering to the sides of the stem at first, but soon becoming quite free; fragile; glabrous, with a semi-transparent appearance; colour variable-entirely whitish, flesh colour, yellowish or tawny. S. $2 \frac{1}{2}-4$ in., stout, narrowed upwards, with many ribs enclosing elongated pits, hollow; pure white at first, then yellowish. Gregarious, autumnal, in hedges and under trees.

Helvella lacunosa, "Mitred Helvel." Plate XLVIII. 9.

Asc. $\frac{3}{4}-2 \frac{1}{2}$ in. high, consisting of irregular, drooping, darkgrey or blackish-grey lobes, attached to the stem by the under surface. S. $\frac{3}{4}-3$ in., thick, variously ribbed and pitted, pallid. Solitary or gregarious, frequent in woods in spv. and aut. Variable, but easily known by the dark-grey, irregularly inflated pileus.

Verpa digitaliformis, "Thimble-finger." Plate XLVIII. 2.

Asc. about $\frac{3}{4}$ in. high, olivaceous umber, dark at the apex, thimble-shaped; closely pressed to the stem like a thimble on a finger, but always free from it. $S .3$ in., $\frac{1}{2}$ in. thick or more, slightly attenuated downwards, and ornamented with minute scales. On banks in shrubberies and hedges in spr. Uncommon.

Leotia lubrica, "Lizard-tuft." Plate V. 3 .

Asc. about $\frac{3}{4}$ in., irregularly hemispherical, somewhat gelatinous, wavy, with obtuse margin, yellowish olive-green. S. $I \frac{1}{4}-2 \frac{1}{2}$ in., nearly equal or inflated below, hollow at maturity; yellowish, covered with minute white granules. Terrestrial, in woods in sum. and aut. Gregarious or in small clusters.

Leotia chlorocephala may be easily known by the long, often twisted, green stem.

Mitrophora semilebra, "Tall Morel." Plate V. 3 .

Asc. conical, $\frac{3}{4}-\mathrm{I}$ in. high, and almost as much in diam. at the base. Free from the stem about half-way up, and covered with pronounced, more or less longitudinal ribs, 


\section{DESCRIPTION OF PLATE XLVIII}

SOME SPRING ASCOMYCETES

FIG. I.-Mitrula phalloides.

FIG. 2.-Verpa digitaliformis.

Fig. 3.-Ditto, section.

FIG. 4.-Peziza (Geopyxis) coccinca.

FIG. 5.-Peziza venosa.

Fig. 6.-Mitrophora semilebra.

FIG. 7--Ditto, section.

Fig. 8.-Morchella esculenta.

FIG. 9.-Morchella lacunosa.

FIG. IO.-Ditto. section.

FIG. II.-Gyromitra esculenta.

FIG. I2.-Ditto, section. 


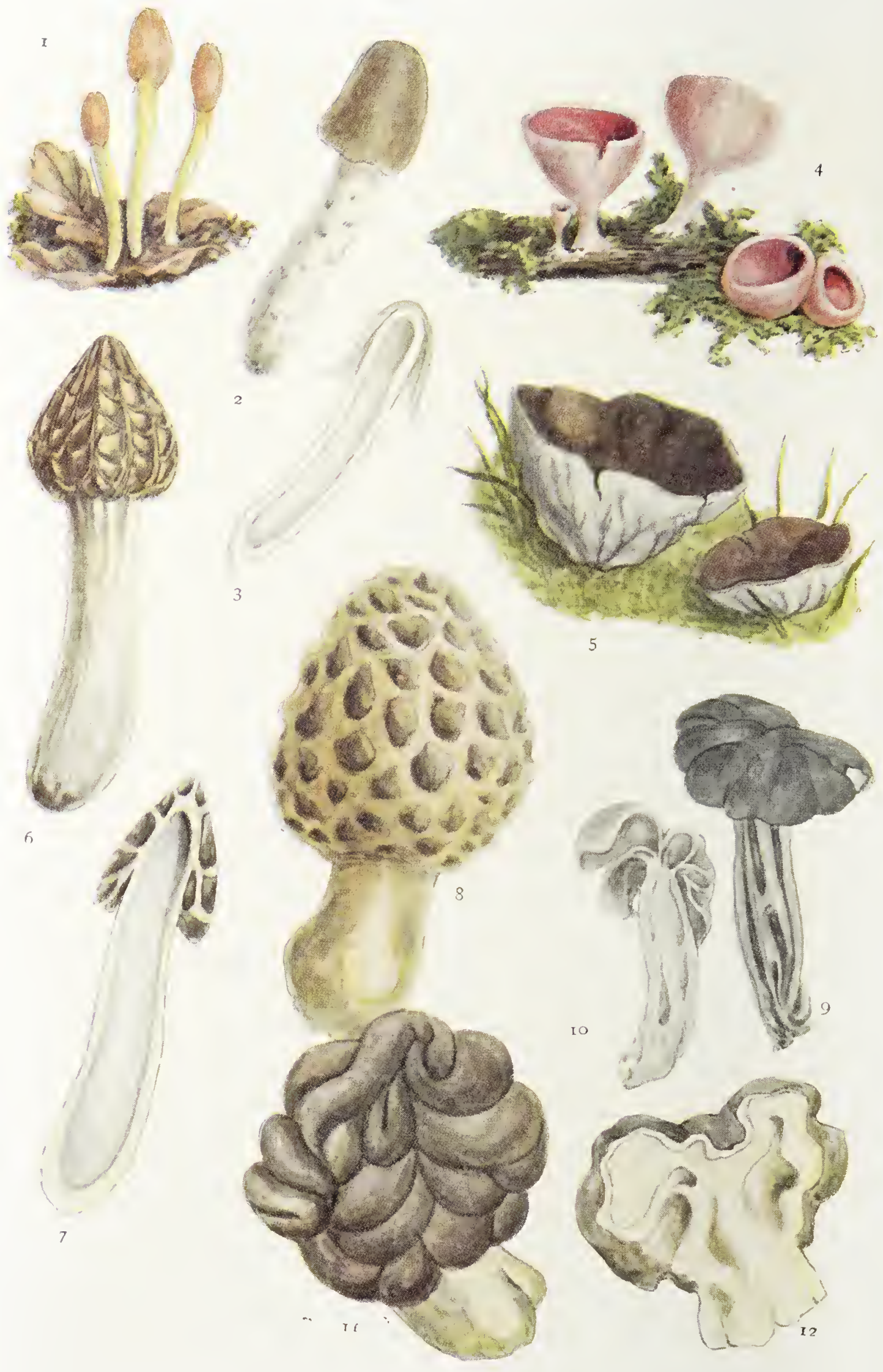


which form elongated pits by forking; yellowish or dingytawny olive, edges of ribs often darker. $S$. $I \frac{1}{2}-3 \frac{1}{2}$ in., stout, whitish or pallid, hollow. In woods in spv. Uncommon.

Mitrophora gigas differs from the above in being about twice the size, with a very stout stem more or less grooved, and sprinkled with minute rusty scales. A rare vernal species, growing in sandy places.

Morchella esculenta, "Common Morel." Plate XLVIII. 8.

Asc. globose, $1 \frac{1}{4}-2 \frac{1}{2} \mathrm{in}$. high and broad, adnate to the stem at the base, hollow; covered with stout, irregular ribs, forming polygonal pits; colour variable-dingy yellow, buff, or tawny. S. $1_{4}^{1}-2 \frac{1}{4}$ in., stout, hollow, almost even, whitish. Gregarious. Frequent under elms on calcareous soils in spr. and early sum. Edible. The mould, Hypomyces cervinus, sometimes attacks the pileus, causing it to appear as if dusted with snuff.

M. crassipes is much larger (sometimes a foot high and 7 in. diam.), the stem always much longer than the pileus.

M. elata, a fir-wood species, has deep, thin ribs, which run in a parallel manner from the base to the apex of the pileus: stem always furfuraceous. M. conica is closely allied to it, but the stem is never scaly.

Gyromitra esculenta, "Lorchel." Plate XLVIII. II.

Asc. subglobose, somewhat depressed, I $1 \frac{1}{2}-2 \frac{3}{4} \mathrm{in}$. diam., from I-2 in. high, irregularly hollow, wavy, wrinkled, joined here and there to the stem, brown. S. $1 \frac{1}{4}-2 \frac{3}{4}$ in., stout, more or less lacunose; stuffed, then hollow; whitish. Terrestrial in spr., in sandy fir woods. Rare.

G. gigas is of larger size and paler colour. G. Phillipsii, found by Phillips in a field at Sherborne, in $\mathrm{Ox}$ fordshire, is worthy of note here on account of its size. The pilei varied from 3 in. to $3 \mathrm{ft}$. in circumference, and somewhat resembled Sparassis crispa. Gyromita includes some of the largest of the Discomycetes. It differs from 
Helvella in the pileus not being free from the stem at the base. Edible. All the species are very rare.

\section{Mitrula phalloides. Plate XLVI]I. I.}

Asc. $\frac{1}{4}-\frac{1}{2}$ in. broad, often $\frac{1}{2} \mathrm{in}$. high, soft, fragile, becoming hollow, more or less globose or club-shaped ; large specimens are often compressed; yellowish orange, adnate to the stem. S. $\frac{3}{4}-1 \frac{1}{2}$ in., slender, white or tinged with pink or yellow, becoming hollow. The lower margin of the head is sharp and distinct, usually with two notches. Gregarious or clustered on decaying, half-submerged leaves in ditches and on sphagnum in bogs. Vernal. Uncommon.

Geoglossum glutinosum, "Adder's tongue." Plate V. 5. Asc. I $1 \frac{1}{4}-2 \frac{1}{2} \mathrm{in}$. high, oblong-lanceolate, the hymenial part about one-third of the entire length, slightly viscid, more or less compressed, passing imperceptibly into the sticky, brownish-black stem. G. hirsutum differs in the minutely hairy asc. and stem. All the British species are black. Gregarious, amongst grass in fields and lawns in aut.

Bulgaria polymorpha (=inquinans). Plate XLVII. I.

Rusty brown, scurfy, globose at first, becoming plane; black and shining at maturity. The familiar black, tough, rubber-like bodies, $\frac{1}{2}-I \frac{1}{2}$ in. diam., frequent on dead trunks. Ulocolla foliacea (Plate XXVI. 5) is said to be the conidial form of this species.

Cordyceps militaris, "Caterpillar Fungus." Plate XLVII. 2.

Club-shaped, tuberculated, about I in. high, bright scarlet, appearing above the ground, and superficially resembling a Clavaria. Careful examination of the soil always reveals the pupa or larva on which it grows. Sometimes two or three sporophores spring from one insect. Frequent in aut.

C. entomorrhiza, with a brown head, is an uncommon species.

C. ophioglossoides (Plate XVI. 7)-head brownish-black, flesh yellow-is parasitic on Elaphomyces variegatus in pinewoods; uncommon. Corayceps capitata-ovate head and yellow 
stem-is a rare species, parasitic on Elaphomyces gramulatus. A New Zealand species, Cordyccps Robertsii, popularly known as the "Vegetable Caterpillar," is a familiar museum object. The club varies from 4 to 8 inches in length. $C$. sinensis is sold in bundles as an article of food in the markets of China.

\section{Sub-order PYRENOMYCETES}

(See p. I4)

Xylaria hypoxylon, "Candle-snuft Fungus." Plate XLVII. 4 .

Black and white at first, entirely black when old. Shaped like a Clavaria, I-2 in. high, simple or branched, compressed, corky. Very common on old stumps, appearing for many successive years. $X$. polymorpha is a large, thick, simple, club-shaped species, not uncommon on old beech stumps. Gregarious. Whitish at first, then black.

Hypoxylon concentricum. Plate XLVII. Io.

Asc. subglobose, I-I $\frac{1}{2}$ in. diam., brownish at first, then black. Easily recognised by the concentrically-zoned flesh. Common on old ash-trunks. H. coccincum is equally common on beech. Asc. shape and size of a pea. Gregarious. Often confluent, brownish-red outside, black within.

\section{THE TRUE TRUFFLES (TUBERACE}

These comprise a very distinctive family of the Pyrenomycetes.

There are purposely depicted together on Plate XVII. some truffles and false truffles, representatives of the Ascomycetes and Gasteromycetes, to show the remarliable superficial resemblances which are sometimes seen in families belonging to different Orders when living under similar conditions.

All are more or less globose, more or less subterranean, 
and strong-smelling at maturity, and many species in both families exhibit a remarliable predilection for the vicinity of certain trees.

According to present knowledge, truffles are mostly European. It is, however, highly probable that they will eventually be found in all parts of the world. Quite recently many species have been recorded from Tasmania.

In England they occur only on limestone soils, and decrease in number northwards, being most abundant on the challi of the South-Western counties. There are about thirty British species, the majority uncommon or rare.

The smell of a truffle is strong enough to indicate its presence to dogs and pigs, and these animals are trained to seek them. 'The pig (generally a sow) is preferred in France. She scents the truffle at a distance of 20 feet, moving rapidly to the spot, and digging for them with her snout. She is stopped by her owner from obtaining them, and rewarded with an acorn or dry chestnut. In this country a dog is employed in the quest, a small white or blacli-and-white poodle, said to possess the homing faculty of a pigeon.

Mr. Alfred Collins, a well-known Wiltshire truffler, writes me that his dogs "in worling would pass over the young truffles as if they were stones, as there is nothing whatever to attract their attention, there being no scent until the truffle begins to ripen, when it becomes very strong. In extreme cases our dogs have been known to scent a truffle from 60 to 80 yards distance. Of course, that would need the wind right. In such cases the dog takes a direct line for the truffle, which is usually about 2 in. below the surface." Mr. Collins recollects but one occasion in which he found truffles with his dogs "outside" of the middle of Sept. and the middle of $F e b$.

Berkeley observed: "Like most articles of food which are not in general use, a taste for truffles is an acquired one, 
but those who are once accustomed to their flavour are mostly enthusiastic in their praise. Some persons, however, turn from them with disgust, declaring that they resemble nothing so much as an old shoe-sole stewed."

Tuber æstivum, "Edible British Truffle." Plate XVII. I.

Black with polygonal warts, section yellowish-brown, mottled with white. Occurring about 3 in. below the soil in plantations chiefly of oak and beech on calcareous and argillaceous soils. Usually the size of a green walnut, but specimens have been taken which turned the scale at $4 \mathrm{lb}$. Gregarious, occurring with other species. Scentless when young, smell strong and potent when mature. Much eaten by squirrels and other mammals; also by insects, chiefly beetles. Berkeley records nine British species of Tuber. Asci of T. vufum are delineated on Plate XVII.

Choiromyces meandriformis, "White Truffle." Plate XVII. 4 .

Colour, appearance, and size of an ordinary potato; section marbled with brown and white veins; white when young. Sometimes very large. I have taken specimens in Dorset more than 5 in. diam. Gregarious. Chiefly under oaks in hilly districts. Usually half buried in stiff soil. Scentless at first, fetid at maturity.

Elaphomyces variegatus. Plate XVII. 7.

About the size and shape of a green walnut, occurring 2 in. below the ground in sandy fir woods. Its presence is usually betrayed by the head of its parasite, Cordyceps ophioglossoides, appearing above the ground. Elaphomyces gramulatus, a rare species, occurring in similar situations, is attacked by Cordyceps capitata (see p. I 86).

In addition to the above, nine other genera of truffles are briefly described by Berkeley in "Outlines of British Fungology." The majority of the species are either uncommon or rare. 



\section{APPENDIX}

\section{CONCERNING SPORES}

From observations by Professor Reginald Buller* on the production, liberation, and dispersion of the spores of Hymenomycetes, it would appear that the paraphyses are useful as spacial agents, preventing the adhesive spores of adjacent basidia from coming into contact during development and discharge.

Large fungi liberate an enormous number of spores, amounting to thousands of millions. A specimen of Agaricus campestris produced approximately I,800,000,000 spores, and one of Coprimus comatus 5,240,000,000. From a computation based on the average length of some spores of the latter it was found that the spores would, if placed end to end, stretch through a distance of forty-one miles!

Numerous as are the spores of Coprimus comatus, they pale into insignificance compared with those produced by $\mathrm{Cal}$ vatia gigantea (Lycoperdon bovista, Linn.), the Giant Puffball. A large dry specimen of this fungus, collected by Dr. Wright Wilson and given to the University of Birmingham, was calculated to have "produced about 7,000,000,000,000 spores, or as many as would be liberated by about 4,000 good-sized mushrooms. Probably a large Giant Puffball which, it is said, may sometimes almost attain the dimensions of a sheep, is the most prolific organism living on our planet."

A specimen of Polyporus squamosus gave off clouds of spores

* See his "Researches on Fungi," recently published by Messrs. Longmans, Green and Co. 
continuously for thirteen days. Professor Buller thinks " that for every spore which succeeds in developing into a mature plant, producing reproductive bodies, something like I,000,000,000,000 spores are wasted. How slight must be the chances for any given spore of Polyporus squamosus finding a suitable substratum for successful development!"

Professor Buller discovered that spores falling from any Hymenomycete suspended in a suitable glass chamber, such as a closed beaker, can be seen in clouds, or individually, without magnification by using a concentrated beam of light. The demonstration of this can very well be carried out at any time, for Lenzites betulina, Polystictus versicolor, and other woody species that can be kept dry in bottles for months or years will quickly revive after wet cotton-wool has been placed on the top of the pileus, begin to shed their spores within six hours, and continue to emit them for days.

It was calculated that large sporophores of Agaricus campestris, Coprimus comatus, Polyporus squamosus, etc., shed about a million spores a minute for two or more days.

"When a fruit-body is placed in hydrogen or carbon dioxide, the liberation of spores quickly ceases. The presence of oxygen in the surrounding atmosphere appears to be essential for the continuance of spore-discharge. In pure oxygen, fruit-bodies shed their spores for several hours at the same rate as in air.

"When a fruit-body is subjected to the vapour of ether or chloroform, spore-discharge ceases almost instantaneously, but can be resumed when the anæsthetic has been removed. A fruit-body of Lenzites betulina recovered its spore-liberating function after this had been inhibited by ether vapour for a week.

"The four spores on each basidium are discharged successively. They leave the sterigmata within a few seconds or minutes of one another. Each spore is shot out violently from its sterigma to a distance of about $\frac{1}{10} \mathrm{~mm}$."

It is usually said that the gills of the Coprini dissolve 
away into an inky fluid, which is visited by flies, the flies licking up the ink and thus dispersing the spores. But Professor Buller has demonstrated that the spores are in reality distributed by the wind, and that the spore-discharge from a gill is not general all over its surface, as in a mushroom, but extremely local. It begins on both sides simultaneously, towards the base. After the basidia have discharged their spores they become disorganized and turn into fluid. They are thus cleared out of the way to allow the pileus gradually to turn outwards, and cause the production of spaces between the lower end of the gills, higher and higher up as these become shorter and shorter.

"If one allows an upright fruit-body (sporophore of a Coprinus), with its stipe placed in wet sand, to shed its spores under a bell-glass, one finds by microscopic examination that the inky drops produced by autodigestion ('deliquescence') consist of a brown fluid containing granules, but practically free from spores. The fluid, therefore, is not made black by spores. The colour is probably due to an oxydase which unites the oxygen of the air with some substance liberated from the dying cells, for it was found that the colourless juice squeezed from an unripe pileus turns brown in a few hours. The drops collect only on the rim of the pileus, where they do not interfere with the liberation of the spores into the air. If paper is placed around the base of the stipe, a black spore-deposit collects upon it, which is similar to that produced under the same conditions by an ordinary Agaric.

"In Nature, the fluid produced by autodigestion is largely got rid of by evaporation. The amount of it adhering to the pileus rim varies considerably according to the state of the weather. In very dry weather it often happens that actual drops are not formed at all. On the other hand, dripping is favoured by a saturated atmosphere, and was found to take place regularly with fruit-bodies placed in a damp chamber." 


\section{I94 FUNGI AND HOW TO KNOW THEM}

Professor Buller thinks that slugs play no important part in spore-dispersal. "Although it may be true that slugs help in the local dispersal of spores in a wood or field, and provide conditions for their germination, these animals, owing to their slow rate of movements, could scarcely act as agents in spreading fungus species from wood to wood when these are separated by considerable distances." $\mathrm{He}$ remarks that herbivorous birds, toads, slugs, insects, worms, etc., must very frequently devour spores with their food, but he apparently attaches no importance to the fact that slugs, insects, and worms are the chief diet of many birds. The possibilities of very wide distribution by birds are evident from Mr. Robert Newstead's note on the stomach-contents of a cuckoo, taken in Cheshire on April 27, 1903. The stomach was filled with a black pulverized mass of spinose hairs, mandibles, thoracic sclerites, etc., of a Lepidopterous larva, evidently all of the same species. The remains were unlike those of any British species, and it was considered highly probable that they were of tropical origin. 


\section{INDEX OF SPECIES ILLUSTRATED}

abietina (Clavaria), Pl. XXIX. 4 abietinus (Polystictus), Pl. XXXIII. 2, 3 acerinum (Rhytisma), Pl. XIV. 2 adiposa (Pholiota), Pl. XIII. 4, 5 æruginosa (Stropharia), Pl. XXXVIII. 7-9 æstivum (Tuber), Pl. XVII. I-3 alnitorquus (Ascomyces), Pl. XIV. 6 androsaceus (Marasmius), Pl. X. 9 annosus (Fomes), Pls. VI. 9 ; XII. anomela (Solenia), Pl. XXX. 6-8 argillacea (Clavaria), Pl. XXIX. I arvensis (Agaricus), Pl. XXXVIII. I 3, I4 asterophora (Nyctalis), Pl. XI. I, 2 asterosperma (Octaviania), Pl. XVII. 9-I I atramentarius (Coprinus), Pl. XXXVII. 7-Io aurantiacus (Cantharellus), Pl. VII. I, 2 aurantiacus (Phallus), Pls. III., XXIV. I aurantium (Scleroderma), Pl. XVIII. I, 2 aurantia (Peziza), Pl. XLVII. 7 auricula-judæ (Hirneola), Pl. XXVI. 8, 9 auriscalpium (Hydnum), Pl. XXXI. 3, 4

badia (Peziza), Pl. XIVII. 5 badius (Boletus), Pl. XXXIV. 6 betulinus (Lenzites), Pl. XLV. I 3-I 5 betulinus (Polyporus), Pl. XIII. 7 Bryantii (Geaster), Pl. XXII. 2, 3 butyracea (Collybia), Pls. VII. 9 ; XXXV. 3

cælata (Calvatia), Pl. XXI. 4 cælatum (Lycoperdon), Pl. XXI. 4 calochrous (Phlegmacium), Cort., Pl. XXXIX. 9, Io campanulatus (Panæolus), Pl. XXXVII. 3 campestris (Agaricus), Pls. IV. I-6; XXXV. 2 caninus (Dermocybe) Cort., Pl. XXXIX. 5, 6 caninus (Mutinus), Pl. XXIV. 4, 5 capillaris (Mycena), Pl. X. 4, 5 r:apula (Cyphella), Pl. XXX. 3-5 carbonaria (Flammula), Pl. XLI. IO, I I carotæcolor (Hydnangium), Pl. XVII. I 3, I4 castaneus (Hydrocybe) Cort., Pl. XXXIX. 3, 4 
cervinus (Pluteus), Pl. XLII. I9, 20 chrysenteron (Boletus), Pl. XXXIV. 4, 5 cibarius (Cantharellus), Pl. XV. 3, 4 cinerea (Clavaria), Pl. XXIX. 9

cinnamomeus (Dermocybe) Cort., Pl. XL. I citrinus (Hymenogaster), Pl. XVII. I2 coccinea (Geopyxis), Pl. XLVIII. 4 coccineus (Hygrophorus), Pl. IX. 4-6 cochleatus (Lentinus), Pl. XLV. I, 2 coliformis (Geaster), Pl. XXII. I coliformis (Myriostoma), Pl. XXII. I comatus (Coprinus), Pl. XV. I I-I 3 commune (Schizophyllum), P]. XLV. 6-8 concentrica (Daldinia), Pl. XLVII. IO, I I confluens (Sistotrema), Pl. XXXI. 5-7 cornucopioides (Craterellus), Pl. XXX. I 3, I 4 conigena (Collybia), Pl. X. I 4 , I 5 corrugis (Psathyra), Pl. XXXVIII. 4-6 costatum (Entoloma), Pl. XLII. 8, 9 crispa (Helvella), Pl. XLVII. 3 crispa (Sparassis), Pl. XXVIII. crispa (Trogia), Pl. XLV. 3-5 cristata (Lepiota), P1. XXXVI. I, 2 cristata (Soppittiella), Pl. XXX. Io crustuliniformis (Hebeloma), Pl. XL. 5, 6 cyanoxantha (Russula), Pl. XLIV. I 3, I4

deformans (Ascomyces), Pl. XIV. 5 degener (Xerotus), Pl. XLV. 9, Io deliciosus (Lactarius), Pl. XV. 6, 7 digitaliformis (Verpa), Pl. XLVIII. 2, 3 disseminata (Psathyrella), Pl. XXXVII. 4 drimeia (Russula), Pl. VII. 5, 6 dryophila (Collybia), Pl. VIII. I, 2

echinatum (Lycoperdon), Pl. XX. I, 4 edulis (Boletus), Pl. XV. 8

elatior (Myxacium) Cort., Pl. XXXIX. 7, 8 elegans (Boletus), Pl. XXXIV. 8, 9 elegans (Polyporus), Pl. XXXII. I emetica (Russula), Pl. VIII. 5 encephala (Næmatelia), P1. XXVI. Io, I I epiphyllus (Marasmius), Pl. X. 6 erythropus (Typula), Pl. XXVII. 3 escharoides (Naucoria), Pl. XLI. I4, I 5 esculenta (Collybia), Pl. VII. I 2 esculenta (Gyromitra), $P$ Pl. XLVIII. I I, I 2 esculenta (Morchella), Pl. XLVIII. 8 Eyrei (Chlorospora) Pl. XLIII. 2

fasciculare (Hypholoma), Pl. XXXVIII. IO-I 2 fastigiata (Clavaria), Pl. XXIX. 2 
fellea (Russula), Pl. VIII. 6 ferruginosus (Fomes), Pl. XXXIII. 4 fimbriata (Odontia), Pl. XXXI. 8, 9 fimbriatus (Geaster), Pl. XXIII. 8 fistulosa (Clavaria), Pl. XXVII. 8 flaccida (Clitocybe), Pl. XLVI. IO, I I fœnisecii (Psilocybe), Pl. IX. I, 2 foliacea (Ulocolla), Pl. XXVI. 5 fomentarius (Fomes), Pl. XXXIII. 7, 8 fornicatus (Geaster), Pl. XXIII. 9 fragilis (Bolbitius), Pl. XL. 2 fumosus (Polyporus), Pls. XVI. 7 ; XXXIII. I furfuracea (Tubaria), Pl. XLI. I, 2 furfuraceus (Ascobolus), Pl. V. 8-I 2 fusiformis (Clavaria), Pl. XXVII. 7 fusipes (Collybia), Pl. XLVI. 7-9

galericulata (Mycena), Pl. XIVI. I, 2 gambosum (Tricholoma), Pl. IX. I 3, I 4 gelatinosum (Tremellodon), Pl. XXVI. I, 2 gemmatum (Lycoperdon), Pl. XX. 2,3 gibbosa (Trametes), Pl. XXXII. 9, IO glandulosa (Exidia), Pl. XXVI. I, 2 glutinosum (Geoglossum), Pl. V. 5-7 glutinosus (Gomphidius), Pl. XLIII. I

hæmispherica (Lachnea), Pl. XVI. 2 hepatica (Fistulina), Pl. XV. 9, Io hinnuleus (Telamonia) Cort., Pl. XXXIX. I, 2 hirsutum (Stereum), Pl. I. 9 Hudsoni (Marasmius), Pl. X. 7, 8 hygrometricus (Geaster), Pl. XXIII. I-4 hypnophilus (Pleurotus), Pl. X. 2, 3 hypnorum (Galera), Pl. XLI. 7 hypoxylon (Xylaria), Pl. XLVII. 4

imbricatum (Hydnum), Pl. XXXI. I I, I 2 inæqualis (Clavaria), Pl. XXIX. 5 incarnata (Peniophora), Pl. I. 3 impudicus (Phallus), Pls. VI. I ; XXV. involutus (Paxillus), Pl. XL. 7, 8 juncea (Clavaria), Pl. XXVII. 5

Kerverni (Saccobolus), Pl. VI. 8

laccata (Laccaria), Pls. XXXV. 4 ; XLIV. 3-5 laciniata (Thelephora), Pl. XXX. 6 lacrymans (Merulius), Pl. XXXIII. 6 lacunosa (Morchella), Pl. XLVIII. 9, is laminosa (Sparassis), Pl. XXXVIII. lampropoda (Leptonia), Pl. XLII. 3, 4 leporina (Peziza), Pl. XLVII. 8 
limbatus (Geaster), Pl. XXII. 6 Loveianus (Volvaria), Pl. XI. 7-9 lubrica (Leotia), Pl. V. 3-4 luridus (Boletus), Pl. XXXIV. I, 2 luteo-alba (Clavaria), Pl. XXIX. 3 luteus (Boletus), Pl. V. 3-4

mammosus (Geaster), Pl. XXIII. 7 mappa (Amanita), P1. XXXVI. 5, 6 meandriformis (Choiromyces), Pl. XVII. 4, 5 mellea (Armillaria), Pl. XIII. I, 2 melinoides (Naucoria), Pl. XII. 3, 4 mesenterica (Auricularia), Pl. XXVI. 6, 7 mesenterica (Tremella), Pl. I. IO micaceus (Coprinus), Pl. XXXVII. 5, 6 militaris (Cordyceps), Pl. XLVII. 2 minima (Cladoderris), Pl. XXX. I 5 mollis (Crepidotus), Pl. XI. IO- I 2 mucida (Armillaria), Pl. XIII. 3 muscoides (Clavaria), Pl. XXIX, 8

nidorosum (Entoloma), Pl. XLII. I7, I 8 nigrescens (Bovista), Pl. XXI. 3

ochraceum (Hydnum), Pl. XXXI. Io ochroleuca (Russula), Pl. XXXVI. 7, 8 olivacea (Coniophora), Pl. XXX. 5 onotica (Peziza), Pl. XLVII. 6 ophioglossoides (Cordyceps), Pl. XVI. 7 oreades (Marasmius), Pl. IX. 3

parasitica (Nyctalis), Pl. XI. 3, 4 parasiticus (Boletus), Pl. XI. 5, 6 parvula (Volvaria), Pl. XLII. 6, 7 pascua (Nolanea), Pl. XLII. IO-I 2 perennis (Polystictus), Pls. XVI. 6; XXXII. 2, 3 peronatus (Marasmius), Pl. VIII. 7, 8 phalloides (Amanita), Pl. XVI. 8 phalloides (Mitrula), Pl. XLVIII. I pisiformis (Nidularia), Pl. XIX. 6, 7 pistillaris (Clavaria), Pl. XXVII. 6 pithyophila (Clitocybe), Pl. XXXV. 7 plumbea (Bovista), Pl. XXI. I, 2 plumbeum (Lycoperdon), Pl. XXI. I, 2 polygramma (Mycena), Pl. XLVI. 5, 6 polymorpha (Bulgaria), Pl. XLVII. I pratensis (Hygrophorus), Pl. IX. I I, I 2 procera (Lepiota), Pls. XV. I, 2 ; XXXV. 9 pruni (Ascomyces), Pl. XIV. 4 prunulus (Clitopilus), Pl. XLII. I 3-I 6 pura (Mycena), Pls. VIII. 3, 4 ; XXXV. 5 psittacinus (Hygrophorus), Pl. IX. 7, 8 
quercina (Dædalea), Pl. XXXII. I I, I 2 quietus (Lactarius), Pl. XLIV.9, Io quisquillaris (Pistillaria), Pl. XXVII. I

radicata (Collybia), Pl. XLVI. 3, 4 ramealis (Marasmius), Pl. X. I repandum (Hydnum), Pls. XVI. I ; XXXI. I, 2 reticulatus (Pluteolus), Pl. XLI. I 2, I 3 rhodocylix (Eccilia), Pl. XLII. I, 2 rimosa (Inocybe), Pl. XL. 9 rotula (Marasmius), Pl. XXXV. 8 rubescens (Amanita), Pl. XLIV. 7, 8 rubescens (Rhizopogon), P1. XVII. I 5, I6 rubigiriosa (Hymenochæte), Pl. XXX. I I, I 2 rufescens (Geaster), Pl. XXII. 4, 5 rufum (Tuber), Pl. XVII. 6 rufus (Lactarius), Pl. VII. 3, 4 rugosa (Clavaria), Pl. XXIX. 7 rutilans (Tricholoma), Pl. VII. 7, 8

salicinum (Corticium), Pl. XXX. I, 2 scaber (Boletus), XXXIV. 3

Schweinitzii (Polyporus), Pl. XIII. 6 sclerotiorum (Sclerotinia), Pl. V. I, 2 semi-globata (Stropharia), Pl. IX. 9, 10 semilebra (Mitrophora), Pl. XLVIII. 0, ? separata (Anellaria), PI. XXXVII. I, 2 septicus (Pleurotus), Pl. XXXVI. 9 spadicea (Psilocybe), Pl. XXXVIII. I-3 stellatus (Sphærobolus), PIs. VI. 2-6; XIX. 8, 9 squamosus (Polyporus), Pl. XXXIII. 6 squarrosa (Pholiota), XL. 3, 4 striatus (Cyathus), Pl. XIX. I-4 stricta (Clavaria), Pl. XXVII. 9 strobilaceus (Strobilomyces), PI. XXXII. 7, 8 stypticus (Panus), Pl. XLV. I6-I8 subtomentosus (Boletus), P1. XXXIV. 7 subulata (Pterula), PI. XXVII. 4 sulphureus (Polyporus), PI. XXXIII. 5 sulphureum (Tricholoma), Pl. XLIV. I, 2

tenacella (Collybia), Pl. X. IO, I I tenera (Galera), Pl. XLI. 8, 9 tenuipes (Pistillaria), Pl. XXVII. 2 terreum (Tricholoma), Pls. VIII. 9: XXXV. Io torminosus (Lactarius), Pl. XLIV. I I, I 2 torulosus (Panus), Pl. XLV. I I, I 2 tuberosa (Collybia), Pl. IV. 7

umbellatus (Polyporus), Pl. XXXII. 4 umbellifera (Omphalia), Pls. XXXV. 6 ; XLIV. 6 ulmarius (Pleurotus), P1. XXXVI. Io 
vaccinii (Exobasidium), Pl. XIV. I vaginata (Amanitopsis), Pl. XXXVI. 3, 4 variabilis (Claudopus), Pl. XXXV. I vaporaria (Poria), Pl. XVI. 3 variegatus (Elaphomyces), Pl. XVII. 7, 8 velutipes (Collybia), Pl. I. I venosa (Peziza), Pl. XLVIII. 5 vermicularis (Clavaria), Pl. XXIX. 6 verrucosum (Scleroderma), P1. XVIII. 3 vernicosus (Cyathus), Pl. XIX. 5 versicolor (Polystictus), Pl. I. 4-8 vesiculosa (Peziza), Pl. XLVII. 9 violaceus (Inoloma), Cort., Pl. XXXIX. I I, I 2 virgineus (Hygrophorus), Pl. XLVI. I 2, I 3 viscosa (Calocera), Pl. XXVI. I 2 vulgare (Crucibulum), Pl. XIX. IO-I 4 vulgare (Scleroderma), Pls. VI. 7 ; XVII. I, 2 vulgaris (Acetabularia), Pl. XVI. 4 vulgaris (Mycena), Pl. X. I 2, I 3 


\section{N D E X}

ABBREVIATIONS employed, 55 abietina (Clavaria), 83

abietinus (Polystictus), 98 acerinum (Rhytisma), 32

Acetabularia, I 30

acetabulosa (Acetabularia), I 30 acutus (Hydrocybe) Cort., I 24 adiposa (Pholiota), 30, I 30 adusta (Russula), I4O, I 57 adustus (Polyporus), IO2 cenuginosa (Peziza), 4,7 aruginosa (Stropharia), I I6 astivum (Tuber), I89

Agaricaceæ, key to genera of, I07, I08, 109 spore groups of, I IO Agarics and spore-throwing, I 8

Agaricus, I 7

albida (Exidia), I77

albobrunneum (Tricholoma), I73

album (Tricholoma), I 75

alcalina (Mycena), I64

Aldridgea, 87

Algæ, I

Algeriensis (Pilosace), I I 7

alnitorquus (Ascomyces), 33

alutacea (Russula), I 56

amadelphus (Marasmius), I7O

Amanita, I 79

Amanitopsis, I 78

amianthina (Lepiota), I78

ammoniaca (Mycona), I64

androsaceus (Marasmius), I7O

Anellaria, I 2

Animals and spore dispersal, I9 annosus (Fomes), 4, 19, 28, 99

Annularia, I 35

anomalus (Dermocybe) Cort., 122

anomela (Solenia), 9I

anthocephala (Thielephora), 87
Antiquity, 2

Appearances, periodic, 5

appendiculata (Hypholoma), I I5, I 16

argillacea (Clavaria), 84

Armillaria, I 76

armillatus (Telamonia) Cort., I 23 arvensis (Agaricus), 20, I I 8, I 28

Ascobolus, I 8

Ascomyces, 32

Ascomycetes, I8I-I89

I4, I5

Ascophore, 8

Ascus, 9, I 5

aspergillus (Sporodinia), I47

asterophora (Nvctalis), I 40

asterophorus (Hypomyces), I 40

astcrosperma (Octaviania), 58

asterospora (Inocybe), I 28

atramentarius (Coprinus), 23, I I I atropurpureum (Lycoperdon), 65 aurantia (Peziza), I 83

aurantiacus (Canthavellus), I 39

aurantium (Sclevoderma), 60

aurantius (Hypomyces), 98

auvicula-juda (Hirneola), 31, 77

Auricularia, 76

auriscalpium (Hydnum), 92

Australionsis (Lysurus), 73, 74

Badhami (Lepiota), I77

badia (Peziza), I82

badius (Boletus), IO5

Basidium, 8, 14

Batarrea, 72

Beefsteak fungus, 3 I

Beetles in truffles, 20

Berkeley, Rev. M. T., 20, 35, I 88, I 89 
betulina (Lenzites), I37, 192 betulinus (Polyporus), 31, 34, 102 Bibliography, 45

Birds'-nest fungi, 10, 62, 63, 64, 65

blennius (Lactarius), I 52

Bloomfield, Rev. E. N., 2 I

bolaris (Inoloma) Cort., I 22

Bolbitius, I 28

Boleti, change of colour of flesh, I06

Boletus, 104

Boudier, Monsieur Emile, I3I

bovinus (Boletus), IO7

Bovista, 19, 67

bovista (Lycoperdon), 66

bovista (Scleroderma), 6I

Bovistella, 67

British Mycological Society, 25, $38,42,82$

brumalis (Clitocybe), I 49

Bryantii (Geaster), 68

bufonia (Peziza), I 82

Bulgaria, I 86

Buller, Professor, on spores, I9 II 94

Bulliardi (Inoloma) Cort., I22

Bulliardi (Trametes), 97

butyracea (Collybia), I67

celata (Calvatia), 66

calatum (Lycoperdon), 66

carulescens (Phlegmacium) Cort., I 20

caruleum (Corticium), 5, 89

calachrous (Phlegmacium) Cort., I 20

calceum (Corticium), 89

Calocera, 8 I

calva (Mucronella), 95

Calvatia, 66

calyptraformis (Hygrophorus), 6,

I 42

campanulatus (Pancolus), I I 2 campestris (Agaricus), I I 7, I80, I9 I

cancellatus (Clathrus), 74 candidus (Marasmins), I70

caninus (Dermocybe) Cort., I 22

caninus (Mutinus), 2I, 73

Cantharellus, I 39

capillaris (Mycena), I62 capitata (Cordyceps), I86, I87, I 89

capula (Cyphella), 90, 91

carbonaria (Flammula), I 25

carcharias (Lepiota), I 78

carotacolor (Hydnangium), 59

castaneus (Hydrocybe) Cort., I 24 catina (Clitocybe), I 48

ceraceus (Hygrophorus), I 4 I

cervinum (Scleroderma), 60

cervinus (Hypomyces), I 83

cervinus (Pluteus), I 34

chalybea (Leptonea), I 33

Chitonia, I 8

chlorocephala (Leotia), I84

chlorophanus (Hygrophorus), I 4I

Chlorophyll, 2

Chlorospora, I 36

Choiromyces, I 89

chrysenteron (Boletus), 104, 105

chrysodon (Hygrophorus), I43

chrysospermum (Lepedonium), 58

chrysospermus (Hypomyces), I I9

cibarius (Canthavellus), 43, I 39

cilicioides (Lactarius), I 5 I

cinerea (Clavaria), 82

cinnamomea (Leiodes), 20

cinnamomeus (Dermocybe) Cort., I 23

cirrhata (Collybia), 568

citrina (Russula), I 57

citrinus (Hymenogaster), 60

Cladoderris, 90

Clamp connections, 3

Clathrus, 74

Claudopus, I 31

Clavaria, 82

Clavariaceæ, key to genera of, 8 I

clavipes (Clitocybe), I46

Clitocybe, I 46

Clitopilus, I 32 )

clypeatum (Entoloma), I 34

clypeolaria (Lepiota), I 78

coccinea (Peziza), I 82

coccineum (Hypoxylon), I 87

coccineus (Hygrophorus), I 4 I

cochleatus (Lentinus), 20, I 38 , I 39

coliformis (Geaster), 68

coliformis (Myriostoma), 68

Collecting fungi, 38 
collinitus (Myxacium) Cort., I 2 I Collins, Mr. Alfred, 20, I 88

Collybia, I 66

comatus (Coprimus), I I I, I9 I-I93 commune (Schizophyllum), I 36 concentrica (Hypoxylon), I87 confluens (Sistotvema), 92 confusum (Porothelium), 94 conica (Morchella), I85 conicus (Hygrophorus), I4I conigena (Collybia), I68

Coniophora, 86

controversus (Lactarius), I 52

Cooke, Dr. M. C., 23, 35, 38, 4I

Coprinus, I I

Cordyceps, I 86

cormucopioides (Craterellus), 6, 90

coronatus (Geaster), 69

corrugis (Psathyra), II 4

corticatus (Pleurotus), I 44

Corticium, 89

corticola (Mycena), I62

Cortinarius, I I 9-I 24

cossus (Hygrophorus), I 43 costatum (Entoloma), I 33

crassipes (Morchella), I85

Craterellus, 90

Crepidotus, I 25

crispa (Helvella), I 83, I8.4

crispa (Sparassis), 81, I85

crispa (Trogia), I 37

cristata (Lepiota), I 77, I 78

cristata (Soppittiella), 87

Crossland, Charles, 24

Crucibulum, 63

crustuliniformis (Hebeloma), I 27

cucumis (Naucoria), I 27

cyanoxantha (Russula), I 58

cyathiformis (Clitocybe), I 49

Cyathus, 62

Cyphella, 90

cystidia, I 4

Dacromyces, 79

Dacryopsis, 80

Dædalea, 96

dealbata (Clitocybe), I 47

Definition, I, 2

deformans (Ascomyces), 32

degener (Xerotus), I 38

delica (Russula), I 52 deliciosus (Lactarius), I 52, I 53

deliquescens (Dacromyces), 79

dendroides (Dactylium), I 39

densifolia (Russula), I 57

Dermocybe (Cort.), I 22

Descent, I

Desmazieres (Lycoperdon), 66

digitaliformis (Verpa), I 84

Discomycetes, 1 5, I8 I

Dispersal of spores, I 7

disseminata (Psathyrella), II 3

Ditiola, 80

drimeia (Russula), I 59

dryophila (Collybia), I69

Dry rot, 31, 96

Earth-balls, 60, 61, 62

Earth-stars, development of, Io eburneus (Hygrophorus), I 43

Eccilia, I 3 I

echinatum (Lycoperdon), 65

Economic uses of fungi, 34

Edible fungi, 34

Elaphomyces, I 89

elata (Morchella), I 85

elatior (Myxacium) Cort., I 2 I

elegans (Boletus), IO4

elegans (Mycena), I65, I66

clegans (Polyporus), IO I

cmplastrum (Lepiota), I77

emetica (Russula), I60

encephala (Nematelia), 78

Entoloma, I 33

entomorrhiza (Cordyceps), I 86

Environment and monstrosities, 24

epibyrus (Crepidotus), I 25

epiphyllus (Marasmius), I 7 I

epipterygia (Mycena), I63

Equipment for collecting, 37

evicetorum (Clitocybe), I 47

erythropus (Typhula), 85

escharoides (Naucoria), I 27

esculenta (Collybia), I68, I69

esculenta (Gyromitra), I 85

esculenta (Morchella), I 85

eutheles (Inocybe), I 28

Exhibiting fungi, 39

Exidia, 77

Exoascus, 32

Exobasidium, 88

Eyrei (Chlorospora), I 36 
Fairy rings, 7

Families of the Gasteromycetes, 57

fasciculare (Hypholoma), 38, I I 5 fastibile (Hebcloma), I 27

fastigiata (Clavaria), 82

fellea (Russula), I 59

Femsjonia, 80

ferruginosus (Fomes), 100

fibula (Omphalia), I 45

fimbriata (Odontia), 94

fimbriatus (Geaster), 70

fimiputris (Anellaria), II 2

Fistulina, 6, 31, 103

fistulosa (Clavaria), $7,8.4$

flaccida (Lenzites), I 37

flaccidus (Clitocybe), I 49

Flammula, I 25

flavobrunneum (Tricholoma), I73

flavus (Boletus), 104

fanisecii (Psilocybe), I I 5

foetans (Russula), I 40, I60

foliacea (Ulocolla), 78, I 86

fomentarius (Fomes), 31, 34, 99

Fo mes, 99

Food value of fungi, 35

fornicatus (Geaster), IO, 69

Fossil fungi, 2

fragilis (Bolbitius), I 28

fragilis (Clavaria), 84

fragitis (Russula), I60

fragrans (Clitocybe), I 47

fraxineus (Fomes), IOO

Friesii (Lepiota), I 77

fumosus (Polyporus), IO2

furcata (Russula), I 58

furfuracea (Tubaria), I 25

fusiformis (Clavaria), 83

firsipes (Collybia), I 40, I 66

\section{Galera, I 26}

galericulata (Mycena), I64 gallinacea (Clitocybe), I 47

Galls on Rhododendron, 88

galopoda (Mycena), I63

Gardener's Chronicle, 67

Gasteromycetes, development

$$
\text { in, } 9
$$

key to genera of, 56

,
Geaster, 10, 68

geaster (Scleroderma), 6I gelatinosum (Tremellodon), 79 gemmatum (Lycoperdon), 65

Geoglossu m, I 86

geophylla (Inocybe), I 28

geotropa (Clitocybe), 8, I 48

gibbosa (Trametes), 97

Gibbs, Mr. T., 67

gigantea (Calvatia), 66, I9I

gigantea (Clitocybe), I48, I9 I

giganteum (Lycoperdon), 66

giganteus (Polyporus), IO2

gigas (Gyromitra), I 85

gigas (Mitrophora), I 85

Gills, nature of, I 3

glandulosa (Exidia), 77

Gleba, 9

Glossary, 47

glutinosa (Aldridgea), 87

glutinosum (Geoglossum), I 86

glutinosus (Gomphidius), I I 3

Gomphidius, I I 3

gracilis (Psathyrella), I I 3

graminum (Marasmius), I 7 I

grammapodium (Tricholoma),

I 35, I 75, I76

Grandinia, 94

gramulatus (Elaphomyccs), 6r,

I $8 \%$, I 89

granulosa (Grandinia), 94

granulosa (Russula), 160

granulosa (Sepiota), 44, I 78

growth, rapidity of, I I

Guepinia, 80

Gyrocephalus, 79

Gyromitra, I 85

Habitats of agarics, 23

hermatochelis (Telamonia), Cort., I 24

homatopa (Mycena), I63

Hariot, M. P., 62

Hartig, 29

Haslemere Museum, 5, 29, 39, 73,82

Haslemere Muscum Gazette, 36

Hebeloma, I 27

Helvella, I 83 , I 84

hemispherica (Peziza), I 8 I

hepatica (Fistulina), 6, 31, I03

Herpel on making spore prints, 43 
heterophylla (Russula), I 57, I 58 himnuleus (Telamonia) Cort., I 23 Hints on collecting, 37

" on drawing, 4I

," on exhibiting, 39

", on preserving, 40

,, on making spore prints, 43

Hirneola, 77

hirsutum (Stereum), 31, 38, 89, 90

Hoylei (Lycoperdon), 65

Hudsoni (Marasmius), I 7 I

Hutchinson, Miss Truda, 7

Hutchinson, Sir Jonathan, quoted, 36

Hydnaceæ, key to genera of, 9 I

Hydnangiu $m, 59$

Hydn.um, 92

Hydrocybe, (Cort.), I 24

hygrometricus (Geaster), 70

Hygrophorus, I 40

Hymenoch etae, 88

Hy menogaster, 60

Hymenogastraceæ, 58

Hymenomycetes, developinent in, I I genera of, 75

,

, key to families of, 74

Hymenophore, types of, I 2 Hyphæ, 3

Hy pholoma, I I 5

hypnophilus (Pleurotus), I 45

hypnorum (Galeva), I 26

Hypoxylon, I 87

hypoxylon (Xylaria), 6, I87

Hysterangium, 59

ignarius (Fomes), 34, 99

imbricatum (Hydnum), 92

impudicus (Phallus), 4, II, 72, 73

incequalis (Clavaria), 84 inamanus (Tricholoma), I74

incana (Leptonia), I 33

incarnata (Peniophora), 88

infundibuliformis (Clitocybe), I48

Inocybe, I 28

Inoloma (Cort.), I 2 I

inquinans (Bulgaria), I 86

Insects and fungi, I 2

integra (Russula), I 56 involutus (Paxillus), I I9

iris (Mycena), I64

Iron, fungi on, 24

Irpex, 93

Jew's-ear, 3I, 35

juncea (Clavaria), 85

Keys to the Families of the

Gasteromycetes, 57

Hymenomycetes, 74

Keys to the Genera of the

Agaricaceæ, 107, 108, I09

Clavariaceæ, 8 I

Hydnaceæ, 9I

Hymenogastraceæ, 58

Lycoperdaceæ, 64

Nidulariaceæ, 62

Phalloidaceaæ, 72

Polyporaceæ, 95

Sclerodermaceæ, 60

Thelephoraceæ, 86

Tremellinaceæ, 76

Key to the Subgenera of Corti-

narius, I 20

Knapp, I 35

Kneiffia, 94

Labels for fungi, I

laccata (Clitocybe), 24, 44, I 50

laciniata (Thelephora), 87

lavis (Annularia), I 35

lacrymans (Merulius), 23, 3I, 96

Lactarius, I 50

lactea (Mycena), I65

lacteum (Corticium), 89

lacunosa (Helvella), i 84

laminosa (Sparassis), 82

lampropoda (Leptonia), I 32

lancipes (Collybia), I67

lascivum (Tricholoma), I 74

Leaf parasites, 32

Lentinus, I 38

Lenzites, I 37

Leotia, I 84

Lepiota, I 77

leporina (Peziza), I8 3

Leptonia, I 32

Lichens, I

Lightning, 29

limbatus (Geaster), 69

Lloyd, C. G., 19, 6I, 68, 70 
lobata (Auricularia), 76

longipes (Collybia), I 66

Loveiana (Volvaria), I 35, I 46

lubrica (Leotia), I 84

luvidus (Boletus), I06

luteo-alba (Clavaria), 84

luteo-alba (Femsjonia), 80

luteo-virens (Hypomyces), 6 I

luteus (Boletus), IO4

Lycoperdacex, key to genera of, 64

lycoperdi (Cryptophagus), 2 I

Lycoperdon, I9, 65

Lysurus, 73

macilenta (Collybia), I69

macrocarpus (Mucor), I $\sigma_{5}$

maculata (Collybia), I67

mammosum (Tulostoma), $7 \mathrm{I}$

mammosits (Geaster), 69

mappa (Amanita), I 79

Maras mins, 169

marquandi (Verticillium), I 43

Marshall, Miss, 7 I

Massee, G., I 4, 22, 106

mastiger (Psathyra), I I4

maxima (Clitocybe), I 48

meandriformis (Choiromyces), I 89

Mielanogaster, $5 \mathrm{~S}$

melinoides (Nancoria), I 26

mellea (Armillaria), 30, I 76

melleus (Hypomyces), I 39

Mendel, L. B., 35

merismoides (Phlebia), 93

Merulius, 96

mesenterica (Auricularia), 76

mesenterica (Tremella), 78

metachroa (Clitocybe), I 49, I 50

micaceus (Coprinus), I I I, I I 2

michelianus (Geaster), I 8

militaris (Cordyceps), I 86

miniatus (Hygrophorus), I4I

minima (Cladoderris), 90

mirabilis (Queletia), 7 I

mitissimus (Lactarius), I 54

Mitrophora, I 84

Mitrula, I 86

mollis (Crepidotus), I 25

Monstrosities, 24

Montagnites, I 3

Morchella, I 85 mucida (Armillaria), 30, I 76

mucifuns (Myxacium) Cort., I 2 I

Mucronella, 95

muscaria (Amanita), 34, I 80

muscoides (Clavaria), 82

mutabilis (Pholiota), I 30

Mutinus, 73

Mycelium, 2-4

Mycena, I6 I

$$
\begin{array}{ll}
, & \text { vegetative, } 5,6 \\
, & \text { colour of, } 4
\end{array}
$$

Mycetozoa, 2

Myriostoma, 68

myrtillus (Vaccinium), 32

Myxacium, (Cort.), I 2 I

$\mathrm{N} æ$ matelia, 78

nanus (Boletus), IO 5

Naucoria, I 26

nebularis (Clitocybe), I 35, I 46

nephriticum (Hysterangium), 59

Newstead, Robert, 2 I

nidorosum (Entoloma), I 34

Nidularia, 63

Nidulariacea, key to genera of, 62

nigrescens (Bovista), 67

nigricans (Russula), I 40, I 57

nitida (A manita), I8 I

nivalis (Agaricus), I 79

niveus (Hygrophons), I 42, I 43 , I 47

\section{Nolanea, I 33}

muda (Dacryopsis), 8o

nudum (Tricholoma), I 22, I 75

nummularius (Polyporus), IOI

Nutrition, 25

Nyctalis, I 40

obliquus (Irpex), 93

obliquus (Lactarius), 154

obtusus Hydrocybe (Cort.), I 24

ochracea (Hypocrea), IO2

ochracea (Russula), I 59

ochraceum (Hydnum), 92

ochroleuca (Russula), I 59, I60

Octaviania, 58

Odontia, 94

odora (Clitocybe), 20, I 47

olivacea (Coniophora), 86

omphalodes (Humaria), 7

onotica (Peziza), I83 
ophioglossoides (Cordyceps), I86, I 89

orbiculare (Radulum), 93

orcella (Clitopilns), I 32

oreades (Marasmius), I 70, I75

ostreatus (Plenrotus), 24, 38, I 44

Oxalate of lime, 4

paludosa (Bovistella), 67

Panæolus, II 2

Panus, I 38

papilionaceus (Panceolus), I I2, I I 5

Paraphyses, I 4, 15

Parasites, 27 losses caused by, 28

parasitica (Nyctalis), I40

parasiticus (Boletus), 25, 61, I05 parvila (Volvaria), I 35

pascua (Nolanea), I 33

Paxillus, I 19

pelliculosa (Mycena), I63

Peniophora, 88

perennis (Polystictus), 98

Periodic appearances, 5

Perithecium, I 4

perlatum (Iycoperdon), 65

peronatus (Marasmius), I69, I70 personatum (Tricholoma), 44, I75

Peziza, I 8 I-I 83

peziza (Guepinia), 80

Phalline, 36

Phalloidaceæ, I I, 20 72

key to genera of,

phalloides (Amanita), 36, I79, I 80

phalloides (Batarrea), 72

phalloides (Mitrnla), I 86

Phallus, 72

Phillipsii (Gyromitra), I85

Phlebia, 93

Phlegmacium, (Cort.), I 20

pholideus (Inoloma) Cort., I20

Pholiota, I 29

Phosphorescence, 4

phyllophila (Clitocybe), I46, I48

picipes (Polyporus), IOI

Pileus, development of, I I

Pilosace, I I 7

piperatus (Boletus), 6, I07 piperatus (Lactarius), I 52 pisciodora (Nolanea), I 33 pisiformis (Nidularia), 63 pisocarpium (Polysaccum), 6r

Pistillaria, 85

pistillaris (Clavaria), 84

pithyophila (Clitocybe), I 46

Pleurotus, I 43

Plowright, Dr., 24, 36, 38, 42, I 44. I 79

plumbea (Bovista), 67

plumberm (Lycoperdon), 67

Pluteolus, I 29

Pluteus, I 34

Poisonous fungi, 35, I 80

polygramma (Mycena), I65

polymorpha (Bulgaria), 77, 88, I 86

polymorpha (Xylaria), I4, I87

Polyporacex, key to the genera of, 95

Polysaccum, 6 I

Polystictus, 98

Poria, 97

Porothelium, 94

pratensis (Hygrophorns), I42

Preservation of fungi, 40

procera (Lepiota), 44, I 77

prominens (Lepiota), I 77

prini (Ascomyces), 32

primulus (Clitopilus), I 32

Psathyra, I I 4

Psathyrella, II 3

psittacimus (Hygrophorus), I42

Psilocybe, I 4

Pterula, 85

puellaris (Russula), I 56

Puff-balls, development of, 9

"Puffing," I 9

spores of. 19

as styptics, 34

punctatum (Rhytisma), 32

puniceus (Hygrophorus), I 4 I

pura (Mycena), I65

purpurascens (Phlegmacium)

Cort., 120

purpureum (Sterenm), 90

pustla (Bovista), 68

pusillum (Lycoperdon), 68

Pyrenomycetes, I 4, I 87

pyriforme (Lycoperdon), 65

pyriodora (Inocybe), I 28 
Queletia, 7I

Queletii (Russula), I6I

quercina (Dedalea), 96, 97

quietus (Lactarius), I 53

quisquillaris (Pistillaria), 86

rachodes (Lepiota), I 77

radicans (Boletus), IO5

radicata (Collybia), 44, I66

Radulum, 93

ramealis (Marasmins), I 70

Rapidity of growth, I I

Rea, Carleton, 38, 39, 55, 74, 84

Reappearances after long intervals, 6

recisa (Exidia), 77

Red Truffle, 58

repandum (Hydnum), 24, 92

Reproduction, 2, 5

resplendens (Tricholoma), I 72

reticulatus (Pluteus), I 29

Rhizomorphs, 4, 30

Rhizopogon, 59

rhodocylix (Eccilia), I 3 I

rhododendri (Exobasidium), 88

ribis (Fomes), IOO

rimosa (Inocybe), I 28

Robertsii (Cordyceps), I87

rosacea (Russula), I6I

rosea (Peniophora), 88

rosellus (Hypomyces), IOz

roseus (Gomphidius), I I 4

rotula (Marasmius), I7 I

rubescens (Amanita), I80, I8 I

rubescens (Rhizopogon), 59

rubi (Crepidotus), I 25

nubiginosa (Hymenochcete), 88

rubra (Russula), I 59

rubriceps (Chitonia), I I 8

rufescens (Geaster), 69

nufum (Tuber), I 89

rufus (Gyrocephalus), 79

rufus (Lactarius), I 53

rugosa (Clavaria), 83

migosa (Mycena), I 65

rugosum (Stereum), 90

Russula, I 54, I 55

rutilans (Tricholoma), I 73

saccata (Calvatia), 66

saccatum (Lycoperdon), 66

Saccobolus, i 8 sapiaria (Lenzites), I 37 salicinum (Corticium), 89 sambuci (Corticium), 89 sanguifuns (Lactarius), I 53 sanguinea (Russula), I6 I sanguineum (Corticium), 4 sanguineus (Dermocybe) Cort., I 23 saponaceum (Tricholoma), I73, I 74

Saprophytes, 27

scaber (Boletus), , 06

Scent, significance of, I9

Schizophyllum, I 3 , I 36

Schweinitzii (Polyporus), 30, IOO

Scleroderma, 60

Sclerodermaceæ, 2I; key to genera of, 60

Sclerotia, 5, I 6

Sclerotinia, I6, 33

sclerotionum (Sclerotinia), 33

Seasonal fungi, 38

sebacea (Soppittiella), 88

Seeds, vitality of, 7

semibulbosus (Pluteus), I 3 I

semiglobata (Stropharia), I I 7

semilanceata (Psilocybe), I I 5

semilebra (Mitrophora), I84, I85

separata (Anellaria), I I 2

septicus (Pleurotus), I 44

sericeum (Entoloma), I 34

seriflums (Lactarius), I 54

setigera (Kneiffia), 94

Sheep and poisonous fungi, 36

sinensis (Cordyceps), I87

Sistotrema, 92

Sketching fungi, Dr. Cooke on, 4 I

Slugs and fungi, 4, I 2, 2I, I94

Smith, Worthington G., 4, 8, I8, 7 I , 82, I 32 , I 35

Solenia, 9I

Soppittiella, 87

spadicea (Psilocybe), I I4, II 6

Sparassis, 8 I

Spawn, 43

spectabilis (Pholiota), I 30

Sphæria, I 4

Sphærobolus, 64

spissa (Amanta), I8 I

Spores, 2, I9I-I94

. dispersal of, 7-22, I9II94 
Spores, dormancy of, 7

" in the alimentary canal, 20

", prints of, $4 \hat{3}$

" thrown by agarics, I 8 , I 92

Spore groups of the Agaricacex, I IO

Sporophore, 8

spumosa (Flammula), I 26

squamosus (Polyporus), 24, 3I,

34, IO I, I92

squarrosa (Pholiota), I 29

Statistics concerning damage, 28 stellatus (Spharobolus), I 7, 64

Stem, object of, I 8

stercoraria (Stropharia), II

Stereum, 89

storea (Hypholoma), 6

Stinkhorn fungi, I I, 20, 2 I

striatus (Cyathus), 62

stricta (Clavaria), 83

strobilaceus (Strobilomyces), 103

Strobilomyces, $\mathrm{IO}_{3}$

Stropharia, I I 6

stypticus (Panus), I 38

subdulcis (Lactarius), I 49, I 54

sublateritius (Hypholoma), 38,

I 6

sublivida (Lachnea), 24

subsquarrosa (Pholiota), I 30

Subterranean fungi, I9

subtomentosus (Boletus), IO5

subulata (Pterula), 85

sulphurea (Coniophora), 87

sulphureum (Tricholoma), I 74

sulphureus (Polyporus), 5, 3I,

34, IO2

surrectus (Agaricus), I 35

Table of genera of

Agaricaceæ, I IO

Gasteromycetes, 56

Hymenomycetes, 75

tabularis (Dermocybe) Cort., I 22

Telamonia (Cort.), I 23

Temperature, 38

tenacella (Collybia), I69

tenera (Galera), I 26

tenerrima (Mycena), I62

tenuipes (Pistillaria), 85

Terms, glossary of, 47 terreum (Tricholoma), I 73

theiogalus (Lactarius), I 53

Thelephora, 87

Thelephoraceæ, key to genera of, 86

tigrinus (Lentinus), 24

titubans (Bolbitius), I 29

torminosus (Hypomyces), I 5 I

torminosus (Lactarius), I 5 I

Trama, I 3

Trametes, 97

Trees, some parasites of, 30

Tremellinaceæ, key to genera of, 76

Tremellod on, 79

Tricholoma, I 7 I, I 72

Trogia, I 37

Trogii (Clitocybe), I 47

Truffles and trufflers, 20, I87I 89

Truffles, False, 58, 59, 60

tuba (Clitocybe), 146

Tubaria, I 25

Tuber, I 89

Tuberaceæ, I 87

tuberosa (Clavaria), 85

tuberosa (Collybia), I68

tuberosa (Sclerotinia), 33

Tulostoma, 7 I

turgidus (Ascomyces), 33

turpis (Lactarius), I 5 I, I 52

ulicis (Ditiola), 80

ulmarius (Fomes), IoO

ulmarius (Pleurotus), I 43

Ulocolla, 78

umbellatus (Polyporus), IOI, 102 umbellifera (Omphalia), I 32, I45 urens (Marasmius), I 70

vaccinii (Exobasidium), 32, 88

vaginata (Amanitopsis), 44, I78,

I 79

vaporaria (Poria), 93, 97

variabilis (Claudopus), I 3I, I44

variegatus (Elaphomyces), 7, I86,

I 89

variegatus (Melanogaster), 58

varius (Polyporus), Iо I

" Vegetable caterpillar," I87

velleveus (Lactarius), I 58

velutipes (Collybia), 38, I67, I 68 


\section{IO FUNGI AND HOW TO KNOW THEM}

venosa (Peziza), I 82

vermicularis (Clavaria), 84

vernicosus (Cyathus), 63

Verpa, I 84

verrucosum (Sclevoderma), 6I

versicolor (Boletus), 105

versicolor (Polystictus), I 2, 38, 98,

I 92

versipellis (Boletus), IO7

vesca (Russula), I 58

vesiculosa (Peziza), 33, I 82

violacea (Poria), 98

violaceus (Inoloma), Cort., I 2 I

virescens (Namatelia), 78

virgatum (Tricholoma), I 74

virgineus (Hygrophorus), 142 viscidus (Gomphiduus), I.I4

viscosa (Calocera), 8 I

vitilis (Mycena), I64

Voglino, 2 I

Volvaria, I 35

vulgave (Crucibulum), 63

vulgave (Sclevoderma), 2 I, 60, 6I vulgaris (Mycena), I63

vulgaris (Peziza), I 83

Ward, Marshall, 25

Water and spore dispersal, I 8

Watkins, H. T. G., 20

Xerotus, I 38

Xylaria, I 87 

PRINTED BY

BILLING AND SONS, LTD., GUILDFORD 


\section{A SELECTION OF BOOKS}

\section{PUBLISHED BY METHUEN}

\section{$\mathrm{AND}$

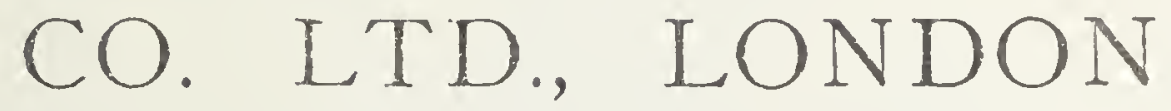

\section{ESSEX STREET \\ W.C.}

\section{CON T E N T S}

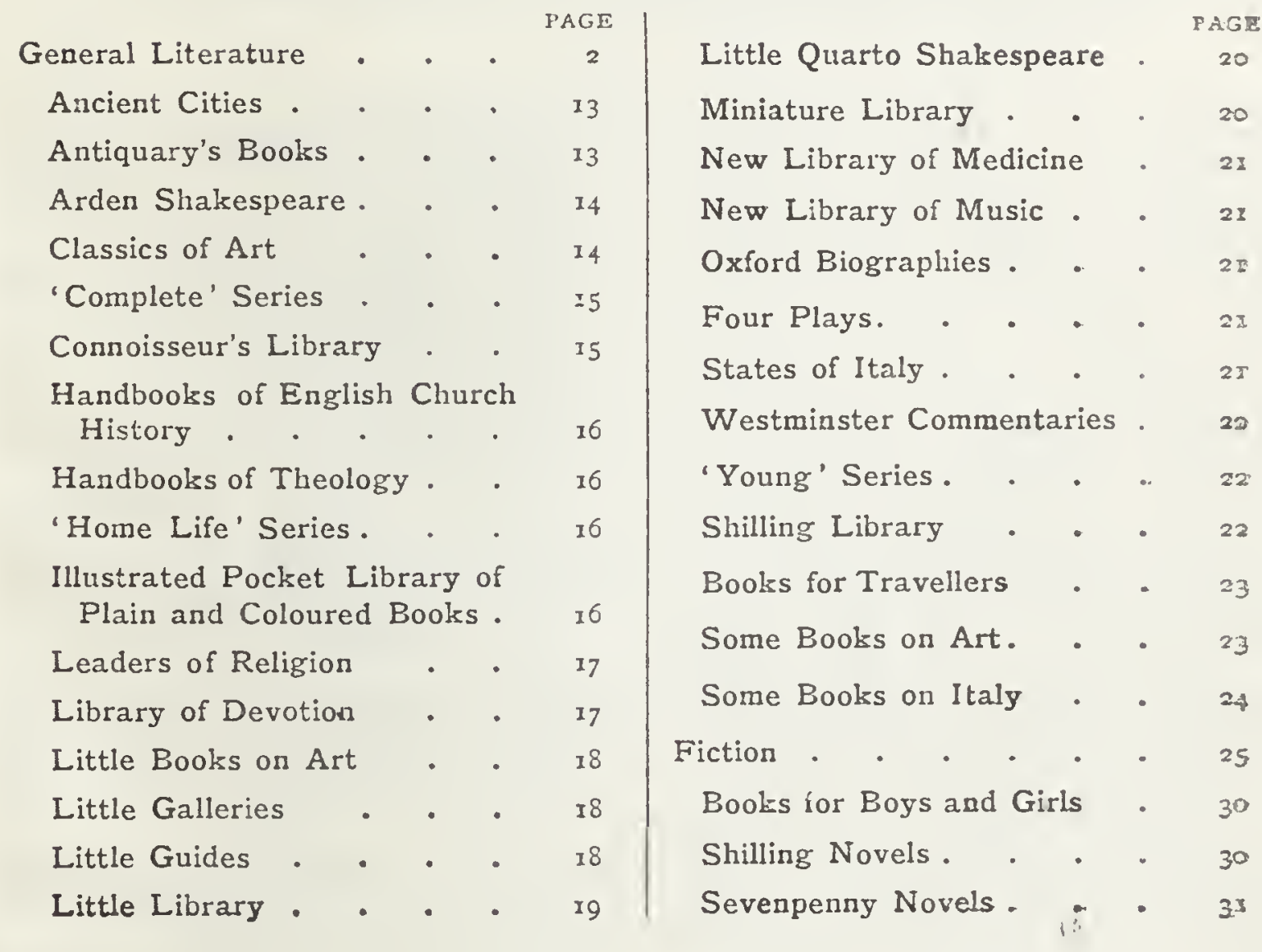




\section{A SELECTION OF}

\section{MessRs. MethuEN'S}

\section{PUBLICATIONS}

IN this Catalogue the order is according to authors. An asterisk denotes that the book is in the press.

Colonial Editions are published of all Messrs. Methuen's Novels issued at a price above 2s. $6 l$. , and similar editions are published of some works of General Literature. Colonial Editions are only for circulation in the British Colonies and India.

All books marked net are not subject to disconnt, and cannot be bought at less than the published price. Books not marked net are subject to the discount which the bookseller allows.

Messrs. MFthUEN's books are hept in stock by all good booksellers. If there is any difficulty in seeing copies, Messrs. Methuen will be very glad to have early information, and specimen copies of any books will be sent on receipt of the published price plus postage for net books, and of the published price for ordinary books.

This Catalogue contains only a selection of the more important books published by Messrs. Methuen. A complete and illustrated catalogue of their publications may be obtained on application.

Abraham (G. D.). MOTOR WAYS IN LAKELAND. Illustrated. Demy $8 v 0$. 7 s. 6 d. net.

Adcock (A. St. John;. THE BOOKLOVER'S LONDON. Illustrated. $\mathrm{Cr}$. 8vo. 6s. net.

*Ady (Uecilia M.). PIUS II.: The Humanist Pope. Illustrated. Demy 8zo. ros. 6 d. net.

Andrewes (Lancelot). PRECES PRI. VATAE. Translated and edited, with Notes, by F. E. Brightman. Cr.8zo. $6 s$.

Aristotle. THE ETHICS. Edited, with an Introduction and Notes, by JOHN BURnet. Demy 8vo. ios. $t$. net.

Atkinson (C. T.). A HISTORY OF GER. MANY, 1715-1815. Demy 8vo. I2s. 6u. net.

Atkinson (T. D.). ENGLISH ARCHI. TECTURE. Illustrated. Third Edition. Fack. 8vo. 3s. 6d. net.

A GLOSSARY OF TERMIS USED IN ENGLISH ARCHITECTURE. Illus. trated. Second Edition. Ficap. 8vo. 3s.6d. net.

ENGLISH AND WELSH CATHEDRALS. Illistrated. Demy Evo. ros. 6u. net.

Bain (F. W.). A DIGIT OF THE MOON: A Hinvoo Love STory. Tenth Lidition. Fras. 820. 3s. Ed. net.
THE DESCENT OF THE SUN : A CYCLE of Birth. Fifth Edition. Fcap. 8ro. 3s. 6 d. net.

A HEIFER OF THE DAWN. Seventh Edition. Fcap. 8vo. 2s. Cd. net.

IN THE GREAT GOD'S HAIR. Fifth Edition. Ficap. 8vo. 2s. 6\%. net.

A DRAUGHT OF THE BLUE. Fifth Edition Fcab. 8vo. 2s. 6d. net.

AN ESSENCE OF THE DUSK. Third Edition. Ficap. 8vo. 2s. 6d. net.

AN INCARNATION OF THE SNOW. Third Edition. Fanp. 8vo. 3s. 6d. net.

A MINE OF FAULTS. Third Edition. Ficap. 8vo. 3s. 6 d. net.

THE ASHES OF A GOD. Second Edition. Fcap. 8ro. 3s. 6d. net.

BUBBLES OF THE FOAM. Fcap. $4^{t}$. 5s. net. Also Fcap. 8vo. 3s. 6d. net.

Balfour (Graham). THE LIFE OF ROBERT LOUIS STEVENSON. Illus. trated. Eleventh Editicn. In one Volume. Cr. 8vo. Buckram, 6s.

Also Fcap. 8vo. Is. net.

Baring (Hon. IMaurice). LANDMARKS IN RUSSIAN LITERATURE. Second Edition. Cr. 8vo. 6s. net.

RUSSIAN ESSAYS AND STORIES. Second Edition. Cr. 8vo. 5s. net.

THE RUSSIAN PEOPLE. Demy \&uo. I5s. net. 
Baring-Gould (S.). THE LIFE OF NAPOLEON BONAPARTE. Illustrated. Second Edition. Royal 8vo. Ios. 6d. net.

THE TRAGEDY OF THE CESARS: A Study of the Characters of the Cesars of the Julian and Claudian Houses. Illustrated. Seventh Edition. Royal 8zo. 1os. 6d. net.

THE VICAR OF MORWENSTOW. With a Portrait. Third Edition. Cr.8vo. 3s.6d. Also Fcap. 8vo. Is. net.

OLD COUNTRY LIFE. Illustrated. Fifth Edition. LargeCr. 8vo. 6s. Also Fcap. 8vo. is. net.

A BOOK OF CORNWAIL. Illustrated. Third Edition. Cr. 8vo. 6s.

A LOOK OF DARTMOOR. Illustrated. Second Edition. Cr. 8vo. $6 s$.

A BOOK OF DEVON. Illustrated. Third Edition. Cr. 8zo. 6s.

Baring-Gould (S.) and Sheppard (H. Fleetwood). A GARLAND OF COUNTRY SONG. English Folk Songs with their Traditional Melories. Demy 4 to. $6 s$.

SONGS OF THE IVEST. Folk Songs of Devon and Cornwall. Collected from the Mouths of the People. New and Revised Edition, under the musical editorship of CECIL J. Sharp. Large Inperial $8 v 0$. 5s. net.

Barker (E.). THE POLITICA L THOUGHT OF PLATO AND ARIS. TOTLE. Demy 8vo. Ios. 6a. net.

Bastable (C. F.). THE COMMERCE OF NATIONS. Sixth Edition. Cr. $8 v 0$. 2s. 6 .

Beckford (Peter). THOUGHTS ON HUNTING. Edited by J. Otho PAGeT. Illustrated. Third Edition. Demy8vo. 6s.

Belloc (H.). PARIS. Illustrated Third Edition. Cr. 8vo. $6 s$.

HILLS AND THE SEA. Fourth Edition. Ficap. 8vo. $5 s$. Also Ficap. svo. is. net.

ON NOTHING AND KINDRED SUB. IECTS. Third Eddition. Ficap. 8vo. $5 s$. oN EVERYTHING. Third Edition. Fcap. 800. 5.5 .

ON SOMETHING. Second Edition. Fcap. $8 v 0.5 s$.

FIRST AND LAST. Second Edition. Fcap. 8vo. 5 s.

THIS AND THAT AND THE OTHER. Second Edition. Fcas. 8vo. 5s.

MARIE ANTOINETTE. Illustrated. Third Edition. Denty 8vo. 15 s. net.

THE PYRENEES. Illustrated. Second Edition. Demy 8vo. 7s.6d. net.

Bennett (Arnold). THE TRUTH ABOUT AN AUTHOR. Crown 8vo. 6s.

Bennett (W. H.). A PRIMER OF THE BIBLE. Fifth Edition. Cr. 8vo. 2s. 6a.
Bennett (W. H.) and Adeney (W. F.). A BIBLICAL INTRODUCTION. With a concise Bibliography. Sixth Edition. Cr. 8vo. 7s. 6\%. Also in Two Voluznes. Cr. 8vo. Each 3s. 6.. net.

Benson (Archbishop). GOD'S BOARD. Communion Addresses. Second Edition. Ficas. 8vo. 3s. 6d. net.

*Berriman (Algernon E.). AVIATION. Illustrated. Cr. 8vo. Ios. 6d. net.

Bicknell (Ethel E.). PARIS AND HER TREASURES. Illustrated. Fcap. $8 v 0$. Round corners. 5s. net.

Blake (William). ILLUSTRATIONS OF THE BOOK OF JOB. With a General Introduction by LAURENCE BINYON. Illustrated. Quarto. 2Is. net.

Bloemfontein (Bishop of). ARA CELI : AN Essay in Mustical Theology. Fifth Edition. Cr. 8to. 3s. Ed. net.

FAITH AND EXPERIENCE. Second Edition. $\mathrm{Cr}$.8vo. 3s. 6d. net.

*Boulenger (G. A.). THE SNAKES OF EUROPE. Illustrated. Cr.8vo. 6s.

Bowden (E. M.). THE IMITATION OF BUDDHA. Quotations from Buddhist Literature for each Day in the Year. Sixth Edition. Cr. $16 m o$. 2s. $6 \%$.

Brabant (F. G.). RAMBLES IN SUSSEX. Illustrated. $\mathrm{Cr} .8 \mathrm{ro}$. $6 \mathrm{~s}$.

Bradley (A. G.). THE ROMANCE OF NORTHUMBERLAND. Illustrated. Third Edition. Demy 8vo. 7s. 6d. net.

Braid (James). ADVANCED GOLF. Illustrated. Seventh Edition. Demy Evo. 1os. 6d. net.

Bridger (A. E.). MINDS IN DISTRESS. A Psychological Study of the Masculine and Feminine Minds in Health and in Dis. order. Cr. 8vo. 2s. 6 d. net.

Brodrick (Mary) and Morton (A. Anderson). A CONCISE DICTIONARY OF EGYPTIAN ARCH AEOLOGY. A Hand. book for Students and Travellers. Illus. trated. Cr. 8vo. 3s. $6 d$.

Browning (Robert). PARACELSUS. Edited with an Introduction, Notes, and Bibliography by MARGARET L. LEE and Katharine B. Locock. Fcap.8vo. 3s.6d. net.

Buckton (A. M.). EAGER HEART: A Christmas Mystery-Play. Eleventh Edi. tion. Cr. 8vo. Is. net.

Bull (Paul). GOD AND OUR SOLDIERS. Second Edition. Cr. 8vo. $6 s$.

Burns (Robert). THE POEMS AND SONGS. Edited by ANDREW LANG and W. A. Craigie. With Portrait. Third Edition. H'ide Demy 8vo 6s. 
Calman (W. T.). THE LIFE OF CRUSTACEA. Illustrated. Cr. 8vo. $6 s$.

Carlyle (Thomas). THE FRENCH REVOLUTION. Edited by C. R. L. Fl.ETCHER. Three Volumes. Cr. 8vo. r8s. THE LETTERS AND SPEECHES OF OLIVER CROMWELL. With an Introduction by C. H. FinTH, and Notes and Appendices by S. C. Lomas. Three Volumes. Demy 8zo. I 8s. net.

Chambers (Mrs. Lambert). L A W N TENNIS FOR LADIES. Illustrated. Second Edition. Cr. 8z'0. 2s. 6d. net.

Chessar (Elizabeth Sloan). PERFECT HEALTH FOR WOMEN AND CHIL. DREN. Cr. 8vo. 3s. 6d. net.

Chesterfield (Lord). THE LETTERS OF THE EARL OF CHESTERFIELD TO HIS SON. Edited, with an Introduction by C. Strachey, and Notes by A. Calthrop. Tavo Volumes. Cr. 8vo. I2s.

Chesterton (G.K.). CHARLES DICKENS. With two Portraits in Photogravure. Eighth Edition. Cr. 8vo. 6s.

Also Fcap. 8vo. is. net.

THE BAILAD OF THE WHITE HORSE. Fourth Edition. Fcap. 8vo. 5s.

ALL THINGS CONSIDERED. Seventh Edition. Fcap. 800. 5 s.

TREMENDOUS TRIFLES. Fifth Edition. Fcap. 8च0. $5 s$.

ALARMS AND DISCURSIONS. Second Edition. Ficap. 8\%o. 5s.

A Miscellany OF MEN. Secona Edition. Ficap. 8vo. 5s.

* Clausen (George). ROYAL ACADEMY LECTURES ON PAINTING. Illustrated. Cr. 8vo. 5s. net.

Conrad (Joseph). THE MIRROR OF THE SEA: Memories and Impressions. Fourth Ectition. Fcap. 8vo. 5s.

Coolidge (W. A. B.). THE ALPS: IN NATURE AND HISTORY. Illustrated. Deny 8vo. 7s. 6d. net.

Correvon (H.). ALPINE FLORA. Trans. lated and enlarged by E. W. Clayforth. Illustrated. Square Demy 8vo. 16s. net.

Coulton (G. G.). CHAUCER AND HIS ENGLAND. Illustrated. Second Edition. Demy 8vo. ros. 6 . net.

Cowper (William). POEMS. Edited, with an Introduction and Notes, by J. C. BAlLEY. Illustrated. Demy 8vo. ros. 6d. net.
Cox (J. C.). RAMBLES IN SURREY. Illustrated. Second Edition. Cr.8vo. 6s.

RAMBLES IN KENT. Illustrated. $C r$. 8vo. 6s.

Crawley (A. E.). THE BOOK OF THE BALL: An Account of What it Does AND Wнy. Illustrated. Cr. 8vo. 3s. 6d. net.

Crowley (H. Ralph). TIIE HYGIENE OF SCHOOL LIFE. Illustrated. Cr. 8zo. 3s. 6d. net.

Davis (H. W. C.). ENGLAND UNDER THE NORMANS AND ANGEVINS: ro66-1272. Thivi Edition. Demy 8vo. Ios. $6 d$. net.

Dawbarn (Charles). FRANCE AND THE FRENCH. Illustrated. Demy $8 v 0$. 1os. $6 d$. net.

Dearmer (Mabel). A CHILD'S LIFE OF CHRIST. Illustrated. Large Cr. 8vo. 6s.

Deffand (Madame du). LETTRES DE LA MARQUISE DU DEFFAND A HORACE WALPOLE. Edited, with Introduction, Notes, and Index, by Mrs. Paget Toynbee. Three Volumes. Demy

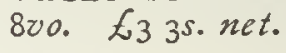

Dickinson (G. L.). THE GREEK VIEW OF LIFE. Eighth Edition. Cr. 8vo. 2s. 6d. net.

Ditchfleld (P. H.). THE OLD.TIME PARSON. Illustrated. Second Edition. Demy 8\%o. 7s. 6d. net.

THE OLD ENGLISH COUNTRY SQUIRE. Illustrated. Demy 8vo. Ios. $6 d$. net.

Dowden (J.), FURTHER STUDIES IN THE PRAYER BOOK. Cr. 800. $6 s$.

Driver (S. R.). SERMONS ON SUR. JECTS CONNECTED WITH THE OLD TESTAMENT. Cr. 8vo. $6 s$.

Dumas (Alexandre). 'THE CRIMES OF THE BORGIAS AND OTHERS. With an Introduction by R. S. GARNETT. Illustrated. Secund Edition. Cr.8vo. 6s.

THE CRIMES OF URBAIN GRAN. DIER AND OTHERS. Illustrated. $C r$. 8vo. 6s.

THE CRIMES OF THE MARQUISE DE BRINVILLIERS AND OTHERS. Illustrated. $\mathrm{Cr}$. 8vo. $6 s$.

THE CRIMES OF ALI PACHA AND OTHERS. Illustrated. Cr. 8vo. 6s.

MY PETS. Newly translated by A. R. Allinson. Illustrated. Cr. 8vo. $6 s$.

Dunn-Pattison (R. P.). NAPOLEON'S MARSHALS. Illustrated. Second Edition. Demy 8vo. 12s. 6d. net. 
THE BLACK PRINCE. Illustrated. Second Edition. Demy 8vo. 7s.6d. net.

Durham (The Earl of). THE REPORT ON CANADA. With an Introductory Note. Demy 8vo. 4s. 6d. net.

Egerton (H. E.). A SHORT HISTORY OF BRITISI COLONIAL POLICY. Third Edition. Demy 8vo. 7s. 6d. net.

Eyans (Herbert A.). CASTLES OF ENGLAND AND WALES. Illustrated. Demy 8vo. i2s. 6 d. net.

Exeter (Bishop of. REGNUM DEI. (The Bampton Lectures of rgor.) $A$ Cheaper Edition. Diny 8vo. 7s. 6d. net.

Ewald (Carl). MY LITTLE BOY. Translated by Alexander TeIXeIRA DE MatTos. Illustrated. Fcap. 8vo. 5s.

Fairbrother (W. H.). THE PHILOSOPHY OF T. H. GREEN. Second Edition. Cr. 8vo. 3s. 6 .

ffoulkes (Charles). THE ARMOURER AND HIS CRAFT. Illustrated. Royal 4to. $\ell_{2} 25$. net.

*DECORATIVE IRONWORK. From the xith to the xvilth Century. Illustrated. Royal 4 to. £2 2s. net.

Firth (C. H.). CROMWELL'S ARMY. A History of the English Soldier during the Civil Wars, the Commonwealth, and the Protectorate. Illustrated. Second Edition. Cr. 8vo. 6s.

Fisher (H. A. L.). THE REPUBLICAN TRADITION IN EUROPE. Cr. 8שo. 6s. net.

FitzGerald (Edward). THE RUBA'IYÁT OF OMAR KHAYYÁM. Printed from the Fifth and last Edition. With a Commentary by H. M. BATSON, and a Biographical Introduction by E. D. Ross. Cr. 8vo. $6 s$.

*Also Illustrated by E. J. Sullivan. Cr. 4to. r5s. net.

Flux (W. W. ECONOMIC PRINCIPLES. Demy 8vo. 7s. 6i. net.

Fraser (E.). THE SOLDIERS WHOM WELLINGTON LED. Deeds of Daring, Chivalry, and Renown. Illustrated. $C r$. 8vo. 5s. net.

*THE SAILORS IVHOM NELSON LED. Their Doings Described by Themselves. Illustrated. Cr. 8vo. 5s. net.

Fraser (J. F.). ROUND THE WORLD ON A WHEEL. Illustrated. Fifth Edition. Cr. 8vo. 6s.
Galton (Sir Francis). MEMORIES OF MY LIFE. Illustrated. Third Edition. Demy 8vo. ros. 6d. net.

Gibbins (H. de B.). INDUSTRY IN ENGLAND: HISTORI CAL OUT. LINES. With Maps and Plans. Seventh Edition, Revised. Demy 8z'o. ros. 6d.

THE INDUSTRIAL HISTORY OF ENGLAND. With 5 Maps and a Plan. Nineteenth Edition. Cr. 8jo. 3s.

ENGLISH SOCIAL REFORMER. Third Edition. Cr. 8vo. 2s. 6d.

Gibbon (Edward). THE MEMOIRS OF THE LIFE OF EDWARD GIBBON. Edited by G. BIRKBECK Hill. Cr. 8\%o. $6 s$.

THE DECLINE AND FALL OF THE ROMAN EMPIRE. Edited, with Notes, Appendices, and Maps, by J. B. Burv, Illustrated. Seven Volumes. Demy 8ro. Illustrated. Each Ics. 6d. net. Also in Seven Volumes. Cr.8vo. 6s. each.

Glover (T. R.). THE CONFLICT OF RELIGIONS IN THE EARLY ROMAN EMPIRE. Fourth Edition. Demy Erio. 7s. 6 d. net.

VIRGIL. Second Edition. Demy 8vo. 75. 6d. net.

THE CHRISTIAN TRADITION AND ITS VERIFICATION. (The Angus Lecture for 19r2.) Cr. 8vo. 3s.6d. net.

Goaley (A. D.). LYRA FRIVOLA. Fourth Edition. Frap. 8vo. 2s. Gd.

VERSES TO ORDER. Second Edition. Fcap. 8vo. 2s. 6\%.

SECOND STRINGS. Fcap. 8vo. 2s. 6.

Gostling (Frances M.). AUVERGNE AND ITS PEOPLE. Illustrated. Demy 8vo. ros. 6d. net.

Gray (Arthur). CAMBRIDGE. Illustrated. Demy 8vo. Ios. 6 d. net.

Grahame (Kenneth). THE WIND IN THE WILLOWS. Seventh Edition. Cr. $820.6 s$.

*Also Illustrated. Cr. 4 to. 7 s. 6 d. net.

Granger (Frank). HISTORICAI, SOCI. OLOGY: A TEXT-BOOK OF POLITICS. Cr. 8vo. 3s. 6d. net.

*Gretton (M. Sturge). A CORNER OF THE COTSWOLDS. Illustrated. Demiy 8vo. 7s. 6i. net.

Grew (Edwin Sharpe). THE GROWTH OF A PLANET. Illustrated. Cr. 8vo. $6 s$.

Griffin (W. Hall) and Minchin (H. C.). THE LIFE OF ROBERT BROWNING. Illustrated. Second Edition. Demy 8vo. 12s. $6 d$. net. 
Haig (R. G.). HEALTH THROUGH DIET. Second Edition. Cr. 8vo. 3s.6d. net.

Hale (J. R.). FAMOUS SEA FIGHTS: From Salamis to Tsu-shima. Illustrated. Second Edition. Cr.8vo. 6s. net.

Hall (H. R.). THE ANCIENT HISTORY OF THE NEAR EAST FROM THE EARLIEST TIMES TO THE BATTLE OF SALAMIS. Illustrated. Second Edi. tion. Demy 8vo. I5s. net.

Hannay (D.). A SHORT HISTORY OF THE ROYAL NAVY. Vol. I., 1217-1688. Vol. II., I689-18I5. Demy 8vo. Each $7 s .6 d$.

Hare (B.). THE GOLFING SWINC SIMPLIFIED AND ITS MECHANISM CORRECTLY EXPLAINED. Third Edition. Fcap.8vo. is. net.

Harper (Charles G.). THE AUTOCAR ROAD-BOOK. With Maps. Four Volumes. Cr.8vo. Each 7s. 6d. net.

Vol. I.-South of the Thames.

Vol. II. - NORTh and SOUTh Wales and West Midlands.

Vol. III.-East Anglia and East Míd. LANDS.

*Vol. IV.-The North of England and South of Scotland.

Harris (Frank). THE WOMEN OF SHAKESPEARE. Demy 8vo. 7s.6d. net.

Hassall (Äthur). THE LIFE OF NAPOLEON. Illustrated. Demy $8 v o$. 7s. 6 d. net.

Headley (F. W.). DARWINISM AND MODERN SOCIALISM. Second Edition. Cr. 8vo. 5s. net.

Fenderson (M. Sturge). GEORGE MEREDITH: NOVELIST, POET, REFORMER. With a Portrait. Second Edition. Cr.8vo. 6s.

Henley (W. E.). ENGLISH LYRICS: CHAUCER TO POE. Second Edition. Cr. 8vo. 2s. 6d. net.

Hill (George Francis). ONE HUNDRED MASTERPIECES OF SCULPTURE. Illustrated. Demy 8vo. Ios. 6d. net.

Hind(C. Lewis). DAYS IN CORNWALL. Illustrated. Third Edition. Cr.8vo. 6s.

Hobhouse (L. T.). THE THEORY OF KNOWLEDGE. Demy 8zo. IOs. 6d. net.

Hobson (J. A.). INTERNATIONAL TRADE: AN APplication OF ECONOMIC ThEORY. Cr. 8vo. 2s. 6d. net.
PROBLEMS OF POVERTY: AN INQUIRY INTO THE INDUSTRIAL CONDITION OF THE Poor. Eighth Edition. Cr. 8vo. 2s. 6d.

THE PROBLEM OF THE UN. EMPLOYED: AN JNQUIRY AND AN Economic Policy. Fifth Edition. Cr.8vo. 2s. $6 d$.

GOLD, PRICES AND WAGES: WITH AN Examination of ThF. Quantity Theory. Second Edition. Cr. 8vo. 3s.6d. net.

Hodgson (Mrs. W.). HOW TO IDENTIFY OLD CHINESE PORCELAIN. Illustrated. Third Edition. Post 8vo. 6s.

Holdich (Sir T. H.). THE INDIAN BORDERLAND, r880-rgoo. Illustrated. Second Edition. Demy 8vo. ros. 6d. net.

Holdsworth (W. S.). A HISTORY OF ENGLISH LAW. Four Volumes. Vols. I., II., III. Demy 8vo. Each ros. 6i. net.

Holland (Clixe). TYROL AND ITS PEOPLE. Illustrated. Demy 8vo. Ios. $6 d$. net.

Horsburgh (E. L. S.). WATERLOO: A Narrative And A Criticism. With Plans. Second Edition. Cr. Svo. $5 s$.

THE LIFE OF SAVONAROLA. Illustrated. Cr. 8vo. 5s. net.

Hosie (Alexander). MANCHURIA. Illus. trated. Second Edition. Demy 8vo. 7 s. 6d. net.

*Howell (A. G. Ferrers). ST. BERNARDINO OF SIENA. Illustrated. Demy 8vo. Ios. $6 d$. net.

Hudson (W. H.). A SHEPHERD'S LIFE: IMPRESSIONS OF THE SOUTH WILT. SHIRE Downs. Illustrated. Third Edition. Demy 8vo. 7s. 6d. net.

Humphreys (John H.). PROPORTIONAL REPRESENTATION. Cr. 8zo. 5s. net.

Hutton (Edward). THE CITIES OF SPAIN. Illustrated. Fourth Edition. Cr. 8v0. 6s.

THE CITIES OF UMBRIA. Illustrated. Fifth Edition. Cr. 8zo. 6s.

THE CITIES OF LOMBARDY. Illustrated. Cr. 8vo. 6s.

*THE CITIES OF ROMAGNA AND THE MARCHES. Illustrated. Cr. 8vo. $6 s$.

FLORENCE AND NORTHERN TUS. CANY WITH GENOA. Illustrated Second Edition. Cr. 8vo. 6s.

SIENA AND SOUTHERN TUSCANY. Illustrated. Second Edition. Cr. 8vo. 6s. 
VENICE AND VENETIA. Illustrated. Cr. 8vo. 6s.

ROME. Illustrated. Third Edition. Cr. 8vo. $6 s$.

COUNTRY WALKS A ROUT FLORENCE. Illustrated. Second Edition. Fcap. 8vo. 5s. net.

A BOOK OF THE WYE. Illustrated. Demy 8vo. 7s. 6d. net.

Ibsen (Henrik). BRAND. A Dramatic Poem, translated by WILIIAM WILSON. Fourth Edition. Cr. 8vo. $35.6 d$.

Inge(W. R.). CHRISTIAN MYSTICISM. (The Bampton Lectures of 1899.) Third Edition. Cr. 8vo. 5s. net.

Innes (A. D.). A HISTORY OF THE BRITISH IN INDIA. With Maps and Plans. Cr. 8vo. $6 s$.

ENGLAND UNDER THE TUDORS. With Maps. Fonrt/ Edition. Demy 8vo. ros. 6 d. net.

Innes (Mary). SCHOOLS OF PAINT. ING. Illustrated. Second Edition. Cr. 8zio. 5s. net.

Jenks (E.). AN OUTLINE OF ENGLISH LOCAL GOVERNMENT. Secona Edition. Revised by R. C. K. ENsor Cr. 8vo. 2s. 6d. net.

A SHORT HISTORY OF ENGLISH LAW: FROM THE EARLIEST TIMES TO THE END OF THE YeAR IgIr. Demy 800. Ios. 6 d. net.

Jerningham (Charles Edward). THE MAXIMS OF MARMADUKE. Second Edition. Fcap. 8vo. 5s.

Jeyons (F. B.). PERSONALITY. Cr. 8vo. 2s. 6d. net.

Johnston (Sir H. H.). BRITISH CEN. TRAL AFRICA. Illustrated. Third Edition. Cr. 4 to. 18 s. net.

THE NEGRO IN THE NEW WORLD. Illustrated. Demy 8vo. 2Is.net.

Julian (Lady) of Noryich. REVELA. TIONS OF DIVINE LOVE. Edited by Grace WARRACK. Fourth Edition. Cr. 8vo. 3s. $6 d$.

Keats (John), POEMS. Edited, with Introduction and Notes, by E. de SÉlincourt. With a Frontispiece in Photogravure. Third Edition. Demy 8vo. 7s. 6d. net.

Keble (John). THE CHRISTIAN YEAR. With an Introduction and Notes by $W$. Lock. Illustrated. Third Edition. Fcap. 8vo. $3 s .6 d$.
Kempis (Thomas à). THE IMITATION OF CHRIST. From the Latin, with an Introduction by DEAN FARRAR. Illustrated. Fourth Edition. Facp. 8vo. 3s. 6d.

*THOMAE HEMERKEN A KEMPIS DE IMITATIONE CHRISTI. Edited by Adrian Fortescue. Cr. 4to. EI Is. net.

Kipling (Rudyard). BARRACK.ROOM BALLADS. IIfth Thousand. Thirty. fourtle Fition. Cr. 8vo. Bucliram, 6s. Also Fcap. 8vo. Cloth, 4s. 6d. net; leather, 5s. net.

THE SEVEN SEAS. 9ith Thousand. Trucnty-finst Fdition. Cr. 8vo. Buchram, 6s. Also Fcap. 8vo. Cloth, 4s. 6d. net; leather, 5s. net.

THE FIVE NATIONS. 8ist Thonsand. Eleventh Edition. Cr. 8zo. Buckram, 6s. Also Fcap. 8vo. Cloth, 4s.6d. net; leather, 5s. net.

DEPARTMENTAL DITTIES. Truent" Third Edition. Cr, 8vo. Buckram, 6s. Also Fcrp. 8vo. Cloth, 45. 6d. net; leather 5s. net.

Lamb (Charies and Mary). THE COMPLETE WORKS. Edited, with an Intro. duction and Notes, by E. V. Lucas. A New and Revised Edition in Six Folumes. With Frontispicee. Fcap. 8vo. 5s. each. The volumes are :-

I. Miscellaneous Prost. II. Elia añd THE Last Essays of EI.IA. III. Books for Children. iv. Plays and PoEms. v. and VI. LETTERS.

Lane-Poole (Stanley.). A HISTORY OF EGYPT IN THE MIDDLE AGES. Illustrated. Cr. 8vo. $6 \mathrm{~s}$.

Lankester (sir Ray). SCIENCE FROM AN EASY CHAIR. Illustrated. Seventh Edition. Cr. 8vo. 6s.

Lee (Gerald Stanley). INSPIRED MIL. LIONAIRES. Cr.8vo. 3s. 6r. net.

CROWDS: A STUDY OF THE GFNIUS OF Democracy, and OF THE FEARS, Desires, AND Expectations of tile PeOple. Cr. $820.6 s$.

Lock (Walter). ST. PAUL, THE MASTER BUILDER. Third Edition. Cr. 8vo. 3s. $6 \pi$.

THE BIBLE AND CHRISTI IN LIFE. Cr. 8vo. 6s.

Lodgo (Sir 0lixer). THE SUDSTANCE OF FAITH, ALLIED WITH SCIENCE: A Catechism for Parents and Teachers. Eleventh Edition. Cr. 8vo. 2s. net.

MAN AND THE UNIVERSE: A STUDY OF THE INFLUENCE OF THE ADVANCE IN SCIENTIFIC KNOWLEDGE UPON OUR UNDERSTANDING OF ChRISTIANITY. Nint/s Edition. Demy 8vo. 5s. net. Also Fcap. 8vo. is. net. 
THE SURVIVAL OF MAN : A STUDY IN UNRECOGNISED HuMAN FACULTY. Fifth Edition. Wide Cr. 8vo. 5s. net.

REASON AND BELIEF. Fifth Edition. Cr. 8zo. $3 s .6$. net.

MODERN PROBLEMS. Cr. 8vo. 5s. net.

Loreburn (Earl). CAPTURE AT SEA. Cr. 8vo. 2s. 6d. net.

Lorimer (George Horace). LETTERS FROM A SELF-MADE MERCHANT TO HIS SON. Illustrated. Twentyfourth Edition. Cr. 8vo. 3s. 6d. Also Fcap. svo. is. net.

OLD GORGON GRAHAM. Illustrated. Second Edition. Cr. 800. 6s. Also Cr. 8v0. 2s. net.

Lucas (E. Y.). THE LIFE OF CHARLES LAMB. Illustrated. Fifth Edition. Demy 8vo. 7s. Ed. net.

A WANDERER IN HOLLAND. Illus. trated. Fourtecnth Edition. Cr. 8vo. 6s.

A WANDERER IN LONDON. Illustrated. Fifteenth Edition, Revised. Cr. 8vo. 6.

A WANDERER IN PARIS. Illustrated. Tenth Edition. Cr. 8vo. 6s. Also Fcap. $8 \pi 0.5 s$.

A WANDERER IN FLORENCE. Illus. trated. Fourth Edition. Cr. 8vo. $6 s$.

THE OPEN ROAD: A LitTle Book For WAYFARERs. Twenty-first Edition. Fcap. 8vo. 5s. India Paper, 7s. 6d. Also Illustrated. Cr. 4 to. Iss. net.

THE FRIENDLY TOIVN : A LiTTLE Book FOR THE URBANE. Seventh Eidition. Fcap. $8 v 0$. 5s.

FIRESIDE AND SUNSHINE. Seventh Edition. Fcap \&vo. 5s.

CHARACTER AND COMEDY. Sixth Edition. Fcap. 8\%o. 55 .

THE GENTLEST ART: A CHOICE OF LetTers by Entertaining Hands. Seventh Edition. Ficap. 8vo. 5s.

THE SECOND POST. Third Edition. Ficap. 800. 5s.

HER INFINITE VARIETY : A FEMININE Portrait Gallery. Sixth Edition. Fcap. 8vo. $5 s$.

GOOD COMPANY: A Rally of MEN. Second Edition. Fcap. 8v0. 5 s.

ONE DAY AND ANOTHER. Fifth Edition. Fcap. 8vo. 5s.

OL.D LAMPS FOR NEW. Fourth Edition. Fcap. 8vo. $5 s$.

*LOITERER'S HARVEST. Fcap. 8 ro. $5 s$.

LISTENER'S LURE: AN OBlique NARRATION. Ninth Edition. Fcap. 8vo. 5 s.

OVER BEMERTON'S: AN EAsY-GOING Chronicle. Tenth Edition. Fcap. 8vo. 5 s.
MR. INGLESIDE. Tenth Edition. Fcap. 8vo. 5 s.

*LONDON LAVENDER. Fcap. 8vo. 5 s.

THE BRITISH SCHOOL : AN ANECDOTAL Guide to the British Painters and Paintings in the National Gallery. Fcap. 8vo. 2s. 6d. net.

HARVEST HOME. Fcap. 8vo. Is. net.

A LITTLE OF EVERYTHING. Third Edition. Fcap. 8vo. Is. net.

See also Lamb (Charles).

Lydekker (R.). THE OX AND ITS KINDRED. Illustrated. Cr. 8vo. $6 s$.

Lydekker (R.) and others. REPTILES, AMPHIBIA, FISHES, AND LOWER CHORDATA. Edited by J. C. CunNing. HAM. Illustrated. Demy 8vo. ros. 6d. net.

Macaulay (Lord). CRITICAL AND HISTORICAL ESSAYS. Edited by F. C. Montague. Three Volumes. Cr. $8 v 0$. 18 s.

McCabe (Joseph). THE EMPRESSES OF ROME. Illustrated. Demy $8 v o$. j2s. $6 d$. net.

THE EMPRESSES OF CONSTANTINOPLE. Illustrated. Demy 8zo. ros. $6 d$. net.

MacCarthy (Desmond) and Russell (Agatha). LADY JOHN RUSSELL: A MemoIr. Illustrated. Fourth Edition. Demy 8vo. Ios. 6 d. net.

McDougall (William). AN INTRODUC. TION TO SOCIAL PSYCHOLOGY Seventh Edition. Cr. 8vo. 5s. net.

BODY AND MIND: A History AND A DefENCE of ANIMISm. Second Edition. Demy 8v0. Ios. 6r. net.

Materlinck (Maurice). THE BLUE BIRD: A FAIRY Play in Six ACts. Translated by ALExANDER TEIXEIRA DE Mattos. Ficrp. 8zio. Deckle Edges. 3s. E net. Also Fcap. 8vo. is. net. An Edition, illustrated in colour by F. CAYI.EY ROBINson, is also published. Cr. 4 to. 21s. net. Of the above book Thirty-three Editions in all have been issued.

MARY MAGDALENE: A PLAY IN THREE Acts. Translated by Alexander Teixeira DE MATtos. Third Edition. Fcap. 820. Declile Edges. 3s. 6d. net. Also Fcap.8vo. is, net.

*OUR ETERNITY. Translated by AlEx. ander Teixeira de Mattos. Fcap.8vn. 5s. net.

* Haeterlinck (Mme. M.) (Georgette Leblanc). THE CHILDREN'S BLUEBIRD. Translated by Alexander Teixeira de Matros. Illustrated. Fcap. 8v0. 5s. net. 
Mahaffy (J. P.). A HISTORY OF EGYPT UNDER THE PTOLEMAIC DYNASTY. Illustrated. $C r .870 .6 s$.

Maitland (F.W.). ROMAN CANON LAW IN THE CHURCH OF ENGLAND. Royal 8vo. 7s. 6d.

narett (R. R.). THE THRESHOLN OF RELIGION. Nere and Revised Edition. Cr. 8vo. 5s. net.

Marriott (Charlos). A SPANISH HOLIDAY. Illustrated. Demy 8vo. 7s.6d. net. THE ROMANCE OF THE RHINE. Illustrated. Demy 8io. Ios. 6d. net.

Marriott (J. A. R. R.). ENGLAND SINCE WATERLOO. With Maps. Demy 8ro. Ios. 6 d. net.

Masefleld (Johr). SEA LIFE IN NELSON'S TIME. Illustrated. Cr. $8 v 0$. $3^{s .6}$. net.

A SAILOR'S GARLAND. Selected and Edited. Second Edition. Cr. 8vo. 3s.6d. net.

Masterman (C. F. G.). TENNYSON AS A RELIGIOUS TEACHER. Second Edition. Cr. 8vo. $6 s$.

THE CONDITION OF ENGLAND. Fourth Edition. Cr. 8vo. 6s. Also Fatp. 8ro. Is net. Also Fcrp. 8vo. is. net.

Mayne (Ethel Colburn). BYRON. Illustrated. Two Volumes. Deny 8vo. 2Is. net.

Medley (D. J.). ORIGINAL ILLUSTRATIONS OF ENGLISH CONSTITU. TIONAL HISTORY. Cr. 8vo. 7s.6d. net.

Methuen (A.M. S.). ENGLAND'S RUIN : Discussed in FOURTEEN LeTters to A Protectionist. Ninth Edition. Cr. Suo. 3d. net.

Miles (Euetace). LIFE AFTER LIFE; or, The Theory of Reincarnation. Cr. 8vo. 2s. 6d. net.

THE POWER OF CONCENTRATION : How TO ACRUIRe IT. Fourth Edition. Cr. 8vo. 3s. 6d. net.

Milais (J. G.). THE LIFE AND LETTERS OF SIR JOHN EVERET' MILLAIS. Illustrated. Nerw Edition. Demy 8vo. 7s. 6d. net.

Mine (J. G.). A HISTORY OF EGYPT UNDER ROMAN RUI,E. Illustrated. Cr. 8vo. 6s.

Mitchell (P.Chalmers). THOMAS HENRY HUXLEY. Fcap. 8vo. Is. net.

Moffat (Mary M.). QUEEN LOUISA OF PRUSSIA. Illustrated. Fourth Edition. Cr. 8vo. 6s.

MARIA THERE.SA. Illustrated. Demy 8\%o. Ios. $6 d$. net.
Money (L. G. Chlozza). RICIES AND POVERTY. Nerw and Revised Issue. Cr. 8vo. is. net.

MONEY'S FISCAL DICTIONARY, IgIo. Second Edition. Demy 8vo. 5s. net.

THINGS THAT MATTER: PAPERS ON SUBJECTS WHICH ARE, OR OUGHT TO BE, under Discussion. Demy 8vo. 5s. net.

Montagne (C. E.). DRAMATIC VALUES. Second Edition. Fapa. 8vo. 5s.

Hoorhouse (E. Hallam). NELSON'S LADY HAMILTON. Illustrated. Third Edition. Demy' 8vo. 7s. 6d. net.

Morgan (C. Lloyd). INSTINCT AND EXPERIENCE. Second Edition. Cr. 8vo. 5. net.

Nevill (Lady Dorothy). MY OWN TIMES. Edited by her Son. Second Edi. tion. Demy 8vo. I5s. net.

O'Donnell (Elliot). WERWOLVES. Cr. 8vo. 5s. net.

Omian (C. W. C.). A HISTORY OF THE ART OF IVAR IN THE MIDDIE AGES. Illustrated. Demy 8vo. Ios. 6d. net.

ENGLAND BEFORE THE NORMAN CONQUEST. With Maps. Third Edition, Revised. Deniy 8vo. Ios. 6d. net.

Oxford (M. N.). A HANDPOOK OF NURSING. Sixth Edition, Revised. Cr. 8vo. 3s. 6d. net.

Pakes (W. C. C.). THE SCIENCE OF HYGIENE. Illustrated. Second and Checper Edition. Revised by A. T. Nankivei.l. Cr. $8 v 0$. 5s. net.

Parker (Enic). A BOOK OF THE ZOO. Illustrated. Second Edition. Cr. 8v0. $6 s$.

Pears (Sir Edwin). TURKEY AND ITS PEOPLE. Second Edition Denry 8r'o. I2s. $6 d$. net.

Petrie (W. M. Flinders.) A HISTORY OF EGYPT. Illustrated. Six Volumes. Cr. 8vo. 6s. each.

VOL. I. FROM THE IST TO THE XVITH Dynasty. Seventh Edition.

Vol. II. ThE XVIITH AND XVIIITH Dynasties. Fift/2 Edition.

Vol. III. XIXTh TO XXXTh DyNasties. Vol. IV. Egypt under the Ptolemaic Dynasty. J. P. Mahaffy.

Vol V. Egypt under Roman Rule. J. G. MILNE.

Vol. VI. Egypt in the Middle $\Lambda$ ges. Stanley Lane-Poole. 
RELIGION AND CONSCIENCE IN ANCIENT EGYPT. Illustrated. Cr.8vo. $2 s .6 d$.

SYRIA AND EGYPT, FROM THE TELL EL AMARNA LETTERS. Cr. 800. 2s. 6 d.

EGYPTIAN TAIES. Translated from the Papyri. First Series, IVth to xith Dynasty. Illustrated. Second Edition. Cr. 800. 3 s. 6 d.

EGYPTIAN TALES. Translated from the Papyri. Second Series, Xvinth to xixth Dynasty. Illustrated. Second Edition. Cr. 8vo. 3s. $6 a^{3}$.

EGYPTIAN DECORATIVE ART. Illus trated. Cr. 8vo $3^{s . ~ o ́ d . ~}$

Pollard (Alfred W.), SHAKESPEARE FOLIOS AND QUARTOS. A Study in the Bibliography of Shakespeare's Plays, 1594-i685. Illustrated. Folio. for is.net.

Porter (G. R.). THE PROGRESS OF THE NATION. A New Edition. Edited by F. W. Hirst. Demy 8vo. EI rs. net.

Pover (J. O'Connor). THE MAKING OF AN ORATOR. Cr. 8vo. $6 s$.

Price (L. L.). A SHORT HISTORY OF POLITICAL ECONOMY IN ENGI,AND FROM ADAM SMITH TO ARNOLD TOYNBEE. Seventh Edition. Cr. 8v0. 2s. $6 d$.

Pycraft (W.P.). A HISTORY OF BIRDS. Illustrated. Demy' 8vo. ros. 6d. net.

Rawlings (Gertrude B.). COINS AND HOW 'TO KNOW THEM. Illustrated. Third Edition. Cr. 8vo. 6s.

Regan (C. Tait). THE FRESHWATER FISHES OF THE BRITISH ISLES. Illustrated. $C r .820 .6 s$.

Reld (Archdall). THE LAWS OF HEREDITY. Second Edition. Demy svo. EI Is. net.

Robertson (C. Grant). SELECT STAT. UTES, CASES, AND DOCUMENTS, 1660-1832. Second, Revised and Enlarged Edition. Demy 8vo. ros. 6d. net.

ENGI,AND UNDER THE HANOVER. IANS. Illustrated. Second Edition. Demy 8vo. Ios. 6a. net.

Roe (Fred). OLD OAK FURNITURE. Illustrated. Second Edition. Demy 8 ro.
* Rolle (RIchard). THE FiRE OF LOVE and THE MENDING OF LIFE. Edited by Frances M. Comper. Cr. 8 vo.

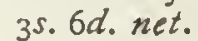

Ryan (P. F. W.). STUART LIFE AND MANNERS: A Social History. Illustrated. Demy 8vo. ros. 6d. net.

* Ryley (A. Boresford). OLD PASTE. Illustrated. Royal 800. 太22s. net.

St. Francis of Assisi. THE LITTLE FLOWERS OF THE GLORIOUS MESSER, AND OF HIS FRIARS. Done into English, with Notes by William HEYwood. Illustrated. Demy 8vo. 5s. net.

- Saki' (H. H. Munro). REGINALD. Third Edition. Ficap. 8v0. 2s. 6d. net.

REGINALD IN RUSSIA. Fcap. $8 v 0$. 2s. 6d. net.

Sandeman (G. A. C.). METTERNICH. Illustrated. Demy 8vo. ros. 6a, net.

Schidrowitz (Philip). RUBBER. Illus. trated. Demy 8vo. Ios. 6 . net.

Schloesser (H. H.). TRADE UNIONISM. Cr. 8vo. 2s. $6 d$.

Solous (Edmund). TOMMY SMITH'S ANIMALS. Illustrated. Twelfth Edi. tion. Faxp. 8vo. 2s. 6 d.

TOMMY SMITH'S OTHER ANIMALS. Illustrated. Sixth Edition. Fcap. 8vo. 2s. $6 d$.

JACK'S INSECTS. Illustrated. $C r .8 v 0.6 s$.

Shakespeare (Wlliam).

THE FOUR FOLIOS, $1623 ; 1632 ; 1664 ;$ 1685. Each $\hbar_{4} 4 s$. net, or a complete set, EI 2 I2s. net.

THE POEMS OF WILLIAM SHAKE. SPEARE. With an Introduction and Notes by George Wyndiam. Demy 8vo. Buck. rain, ros. $6 d$.

Shaw (Stanley). WILLIAM OF GER. MANY. Denny 8vo. 7s. 6d. net.

Shelley (Porcy Bysahe). POEMS. With an Introduction by A. CLUTTON-BROCK and notes by C. D. Locock. Two Volumes. Demy 8vo. EI Is. net.

Smith (Adam). THE IVEALTH OF NATIONS. Edited by EDwin Cannan. Two Volumes. Demy 8vo. EI is. net.

Smith (G. F. Herbert). GEM-STONES AND THEIR DISTINCTIVE CHARAC. TERS. Illustrated. Second Edition. Cr. 8vo. 6s. net. 
Snell (F. J.). A BOOK OF EXMOOR. lllustrated. Cr. 820 . $6 \mathrm{~s}$.

THE CUSTONS OF OLD ENGLAND. Illustrated. $\mathrm{Cr} .8 v 0$. $6 s$.

'Stancliffe.' GOLF DO'S AND DONT'S. Fifth Edition. Fcap. 8vo. Is. net.

Etevenson (R. L.). THE LETTERS OF ROPERT LOUIS STEVENSON. Edited by Sir SIDNEY Colvin. A Nezw and Enlarged Edition in four volumes. Fourtiz Edition. Fcap. 8vo. Each 5s. Leather, each 5s. net.

Storn (Vernon F.). DEVELOPMENT AND DIVINE PURPOSE. Cr. 8vo. 5s. net.

Streatfelld (R. A.). MODERN MUSIC AND MUSICIANS. Illustrated. Second Edition. Demy 8vo. 7s. 6d. net.

Surtees (R. S.). HANDLEY CROSS. Illustrated. Fcap. 8vo. Gilt top. $3^{s .6 d .}$ net.

MR. SPONGE'S SPORTING TOUR. Illustrated. Fcap. 8vo. Gilt tep. 3 s. 6 . net.

ASK MAMMA; OR, THE RICHEST COMMONER IN ENGLAND. Illus. trated. Ficup. 8z'o. Gilt top. 3s. 6d. net.

JORROCKS'S JAUNT'S AND JOLLI. TIES. Illustrated. Fourth Edition. Fcap. 8vo. Gilt top. 35.6 . net.

MR. FACEY ROMFORD'S HOUNDS. Illustrated. Fcap. 8vo. Gilt top. 3s. 6d. net.

HAWBUCK GRANGE; OR, 'THE SPORT' ING ADVENTURES OF THOMAS SCOTT, Esn. Illustrated. Fcap. 8vo. Gilt top. $3^{s .6}$. net.

* Suso (Henry). THE LIFE OF THE BLESSED HENR' I'SUSO. BY HIMSEL. Translated by T. F. Knox. With an Introduction by DEAN INGE. Cr. 8vo. $3 s .6 d$. net.

Swanton (E. W.). FUNGI AND HOW TO KNOW THEM. Illustrated. Cr. 8vo. 6s. net.

I)RITISH PLANT.GALLS. Cr. 8vo. 7s. 6d. net.

Symes (J. E.). THE FRENCH REVO. LUTION. Second Edition. Cr.8vo. 2s.6d.

Tabor (hargaret E.). THE SAINTS IN ART. With their Attributes and Symbols Alphabetically Arranged. Illustrated. Third Edition. Fcaf. 8vo. 3s.6d.net.

Taylor (A. E.). ELEMENTS OF ME'TAPHYSICS. Second Edition. Demy 8 vo. ros. 6 d. net.
Taylor (Hirs. Basil) (Harrlet Osgood). JAPANESE GARDENS. Illustrated. Cr. 4to. EI Is. net.

Thibaudeau (A. C.). BONAPARTE AND THE CONSULATE. Translated and Edited by G. K. Fortescue. Illustrated. Demy 8vo. Ios. 6d. net.

Thomas (Edward). MAURICE MAE. TERLINCK. Illustrated. Second Edition. Cr. 8vo. 5s. net.

Thompson (Francis). SELECTED POEMS OH FRANCIS THOMPSON. With a Biographical Note by WILFRID Meynell. With a Portrait in Photogravure Twentieth Thousand. Ficap. Evo. 5s. net.

Tileston (Mary W.). DALLY STRENGTH FOR DAILY NEEDS. Trenticth Eilition. Medium 16mo. 2s. 6d. net. Also an edition in superior binding, $6 s$.

THE STRONGHOLD OF HOPI Inediun I6ino. 2s. 6d. net.

Toyubee (Paget). DANTE ALIGHISRI. His LIFE AND Works. With ró Hltistra. tions. Fourth and Enlarged Edition. Cr. 8vo. 5s. net.

Treyelyan (G. M.). ENGLAND UNDER THE STUARTS. With Mips and Plans. Fifth Edition. Demy 8vo. Ios. 6d. net.

Iriggs (H. Iniso), TOWN PLANNING : Past, Present, ANd Possible. Illustrated. Second Edition. Wide Royal 8vo. I5s. net.

Turner (Sir Alfred E.). SIXTY YEARS OF A SOLDIER'S LIFE. Demy 8\%0. r2s. $6 d$. net.

Underhill (Evelyn). MYSTICISM. A Study in the Nature and Development of Man's Spiritual Consciousness. Fourth Edition. Demy 8vo. I5s. net.

Urwick (E. J.). A PHILOSOPHY OF SOCIAL PROGRESS. Cr. $8 v 0.6 s$.

Yardon (Harry). HOW TO PLAY GOLF. Illustrated. Fifth Edition. Cr. 8vo. 2s. 6d. net.

Yernon (Hon. W. Warren), READINGS ON THE INFERNO OF DANTE. With an Introduction by the Rev. Dr. Moore. Two Volumes. Second Edition. Cr. 8vo. I5s. net.

READINGS ON 'THE PURGATORIO OF DAN'TE. With an Introduction by the late DEAN CHURCH. Two Volumes. Third Edition. Cr. 8vo. I5s. net. 
READINGS ON THE PARADISO OF DANTE. With an Introduction by the Bishop of Ripon. Tavo Volumes. Second Edition. Cr. 8vo. r5s. net.

Vickers (Kenneth H.). FNGJAND IN THE LATER MIDDLE AGES. With Maps. Demy 8vo. Ios. 6a. net.

Wacle (G. W. and J. H.). RAMBIES IN SOMERSET. Illustrated. Cr.8rc. $6 s$.

Waddell (L. A.). LHASA AND ITS MYSTERIES. With a Record of the Expedition of rgo3-rgo4. Illustrated. Third and Cheaper Edition. Medium 8vo. 7s.6d. net.

Wyagner (Richard). RICHARD WAGNER'S MUSIC DRAMAS. Interpreta. tions, embodying Wagner's own explanations. By Alice Leighton Cleather and Basil Crump. Fcap. 8vo. 2s. 6d. each. The Ring of the Nibelung. Fifth Edition.

JoHENGRIN AND PARSIFAL.

Second Edition, rearitten and enlarged. TRISTAN AND ISOLDE.

TANNhÄUSER AND THE Mastersingers OF NUREMBURG.

Waterhouse (Elizabeth). WITH THE SIMPLE-HEARTED. Little Homilies to Women in Country Places. Third Edition. Small Foit $8 v 0.2 s$. net.

THE HOUSE BY THE CHERRY TREE. A Second Series of Little Homilies to Women in Country Places. Snzall Pott $8 v o$. 2s. net.

COMPANIONS OF THE WAY. Being Selections for Morning and Evening Reading. Chosen and arranged by ElizABETH WatrRHoUse. Large Cr. 8vo. 5s. net.

THOUGH'TS OF A TERTIARY. Small lott 8vo. rs. net.

VERSES. A New Edition. Fcap. 8vo. 2s. net.

Waters (W. G.). ITALIAN SCULPTORS. Illustrated. Cr. 8vo. 7s. 6d. net.

Watt (Francis). EDINBURGH AND THE LOTHIANS. Illustrated. Second Edition. Cr. 8vo. ros. 6d. net.

*R. L. S. Cr. 8vo. 6s.

Wedmore (Sir Frederick). MEMORIES. Second Edition. Demy 8vo. 7s.6d. net.

Weigall (Arthur E. P.). A GUIDE TO THE ANTIQUITIES OF UPPER EGYPT: FROM ABVDOS TO THE SUdAN Frontier. Illustrated. Second Edition. Cr. 8vo. 7s. $6 d$. iet.
Wells (J.). OXFORD AND OXFORD LIFE. Third Edition. Cr. 8vo. 3s. $6 d$.

A SHORT HISTORY OF ROME. Tuelft/ Edition. With 3 Maps. Cr. 8zo. 3s. 6d.

Whitten (Wilfred). 1 LONDONER'S LONDON. Illustrated. Second Fdition. Cr. 800. 6s.

Wllde(Oscar). THE WORKS OF OSCAR WILDE. Truelue Volumes. Ficap. 8vo. 5s. net each volume.

I. Lord Arthur Savile's Crime and The Portrait of Mr. W. H. II. The Duchess OF PADUA. III. Poems. IV. LADY WINDERMERE'S FAN. v. A WOMAN of No IMPORTANCE. vi. AN IDEAL HusBAND. VII. THE IMPORTANCE OF BEING EARNest. VIII. A HOUSE OF POMIEgranates. ix. Intentions. $\mathrm{x}$. DE ProFUNDIS AND PRISON LeTtERS. Xi. Essays. xiI. Salomi, A Florentine Tragedy, and La SaINTE Courtisane.

Williams (H. Noel). A ROSE OF SAVOY : Marie Adél.aide of Savoy, Duchesse DE Bourgogne, Mother of Louis xv. Illus. trated. Second Edition. Demy 8vo. I5s. net.

THE FASCINATING DUC DE RICHE. LIEU: Louis Francois ARMand DU Plessis (r696-i 788). Illustrated. Demy 8 ro. I5s. net.

A PRINCESS OF ADVENTURE: MARIR Caroline, Duchesse ne Berry (r798r870). illustrated. Demy 8vo. I5s. net.

THE LOVE AFFAIRS OF THE COND 4 S ( $530-1740)$. Illustrated. Demy 8vo. r 5 s. net.

*WIIson (Ernest H.). A NATURALIST IN WESTERN CHINA. Illustrated. Demy 8vo. Er ras, net.

Mood (Sir Exelyn). FROM MIDSHIP. MAN TO FICLD-MARSHAL. Illus. trated. Fifth Edition. Demy 8v0. 7s. 6\%. net.

Also Fcap. 8ro. rs. net.

THE REVOLT IN HINDUSTAN (185759). Illustrated. Second Edition. Cr. 8vo. 6.s.

Wood (WH. Birkbeck) and Edmonds (Col. J. E.). A HISTORY OF THE CIVIL WAR IN THE UNITED STATES $(r 86 r-65)$. With an Introduction by SPENSER Wilkinson. With 24 Maps and Plans. Third Edition. Demy 8zo. res. Ed. net.

Wordsrouth (W.). POEMS. With an Introduction and Notes by Nowell C. Smith. Three Volumes. Demy 8\%o. r5s. net.

Yeats (W. B.). A BOOK OF IRISII VERSE. Third Edition. Cr. 8vo. 3s. 6 \%. 


\title{
Part II.--A Selection of Series
}

\section{Ancient Cities}

General Editor, Sir B. C. A. WINDLE

Cr. 8vo. 4s. 6d. net each volume

With Illustrations by E. H. NEw, and other Artists

Bristol. Alfred Harvey.

Canterbury. J. C. Cox.

Chester. Sir B. C. A. Windle.

Dublin. S. A. O. Fitzpatrick.
Edinburgh. M. G. Williamson.

Lincoln. E. Mansel Sympson.

Shrewsbury. T. Auden.

Wells and Glastonburr: T. S. Holmes.

\section{The Antiquary's Books}

\author{
General Editor, J. CHARLES COX \\ Demy 8vo. 75. 6d. net each volume \\ With Numerous Illustrations
}

*ancient Painted Glass in England. Philip Nelson.

Archaiology and False Antiquities. R. Munro.

Bells of England, The. Canon J. J. Raven. Second Edition.

Brasses of England, The. Herbert W. Macklin. Third Edition.

Ceitic Art in Pagan and Christian Trmes. J. Romilly Allen. Second Edition.

Castles and Walled Towns of England, THE. A. Harvey.

Chunchwarden's AcCounts From the Fourteenth Century to the Close of the Seventeenth Century.

Donesday Inquest, The. Adolphus Ballard.

English Church Furniture. J. C. Cox and A. Harvey. Second Edition.
English Costume. From Prehistoric Times to the End of the Eighteenth Century. George Clinch.

ENGlish Monastic Life. Abbot Gasquet. Fourth Edition.

English Seals. J. Harvey Bloom.

Folk-Lore as an Historical Science. Sir G. L. Gomme.

Gilds and Companies of London, The. George Unwin.

* Hermits and Anchorites of England, The. Rotha Mary Clay.

Manor and Manorial Recoris, The. Nathaniel J. Hone. Second Edtition.

Medieval Hospitals of England, The. Rotha Mary Clay.

Old English Instruments of Music. F. W. Galpin. Second Edition. 


\section{The Antiquary's Books-continued}

Old English Libraries. James Hutt.

Old Service Books of the English CHuRch. Christopher Wordsworth, and Henry Littlehales. Second Edition.

Parish Life in Mediaival England. Abbot Gasquet. Third Edition.

PARish Registers of England, The. J. C. Cox.
Remains of the PrRhistoric Age in England. Sir B. C. A. Windle. Second Edition.

Roman Era in Britain, The. J. Ward. Romano-British Buildings and EarthwORks. J. Ward.

Roval Forests of England, The. J. C. Cox.

Shrines of British Saints. J. C. Wall.

\section{The Arden Shakespeare.}

\section{Demy Svo. 2s. $6 a$. net each volume}

An edition of Shakespeare in Single Plays; each edited with a full Introduction, Textual Notes, and a Commentary at the foot of the page

Alz's Well That Ends Well.

Antony and Cleopatra. Sccond Edition.

As YoU LiKe IT.

Cymbeline.

Comedy of Errors, The

HAMLET. Third Edition.

Julius Caesar.

* King Henry iv. Pt. I.

King Hentiy v.

King HENRY VI. PT. 1.

King Henty vi. Pt. il.

King Henry vi. Pt. iII.

KiNg LEAR.

KiNG RiChaRD II.

King RichaRd III.

Iife and Death of King John, The.

Love's Labour's Lost. Second Edition.
Macbeth.

Measure for Measure.

Merchant of Venice, The. Second Edition.

Merry Wives of Windsor, The.

Midsumimer Night's Dream, A.

Othello.

Pericles.

Romeo and JULiet.

TAming of the Shrew, The.

Tempest, The.

Timon of Athens.

Titus Andronicus.

Trollus and Cressida.

Two Gentlemen of Verona, The.

TWelfth Night.

Venus and Adonis.

Winter's Tale, The.

\section{Classics of Art}

Edited by Dr. J. H. W. LAING

\section{With numerous Illustrations. Wide Royal 8vo}

Art of the Greeks, The. H. B. Walters. I2s. 6 d. net.

Art of the Romans, The. H. B. Walters. I5s. net.

Chardin. H. E. A. Furst., 12s. 6d. net.
Donatello. Maud Cruttwell. I5s. net. Florentine Sculptors of the Renais. SANCE. Wilhelm Bode. Translated by Jessie Haynes. ras. $6 d$. net.

GEORGE Roniney. Artbur B. Chamberlain. I2s. 6 d. net. 
Classics of Ant-continued

Ghirlandaio. Gerald S. Davies. Second Edition. I0.s. 6d. net.

LAWRENCE. Sir Walter Armstrong. EI is, net.

Michei angfilo. Gera!d S. Davies. I2s. $6 d$. net.

Raphael. A. P. Oppé. i2s. 6 d. net.

Remrrandt's Etchings. A. M. Hind. Two Volumes. 2is. net.
Rubens. Edward Dillon. 25s, net.

Tintoretro. Evelyn March Plillipps. I5s. net.

Titian. Charles Ricketts. I5s. net.

Turner's Sketches and Drawings. A. Finberg. Second Edition. I2s, Ed. net.

Vei.azQuez. A. de Beruete. iar. 6d. net.

\section{The 'Complete' Series.}

\section{Fully' Illustrated. Demy' 8vo}

The Complete association Footballer. B. S. Evers and C. E. Hughes-Davies. 5s. net.

The Complete Athletic Trainer, S. A. Mussabini. 5s. net.

The Complfite Bilitard Player. Charles Roberts. ros. 6u. net.

The Complete Boxer. J. G. Bohun Lynch. 5s. net.

The Complete Cook. Lilian Whilling. $7 s .6 d$. net.

The Complete Cricketer. Albert E. KNigitT. 7s. 6d. net. Second Edition.

The Complete Foxhunter. Charles Richardson. I2s. 6d. net. Second Edition.

The Complete Golfer. Harry Vardon. Io.s. 6d. net. Thirteenth Edition.

The Conplete Hockey-Player. Eustace E. White. 5s. net. Second Edition.

The Complete Horseman. W. Scarth Dixon. Second Edition. Ios. 6d. net.
The Complete Lawn tenis Player. A. Wallis Myers. ros. 6d. net. Third Edition, Revised.

The Complete Motorist. Filson Young, 12s. 6d. net. New Edition (Seventh).

The Complete Mountaineer. G. D. Abraham. r 5s. net. Second Edition.

The Complete Oarsman. R. C. Lehmann. ios. 6 \% net.

The Complete Photographer. R. Child Bayley. ros. 6d. net. Fourth Edition.

The Complete Rugby Footballer, on the New Zealand System. D. Gallaher and W. J. Stead. ros. 6d. net. Second Ectition.

The Complete Shot. G. T. TeasdaleBuckell. I2s. 6 . net. Third Edition.

The Complete Swimmer. F. Sachs. $7 s, 6 d$. net.

'The Complete Yachtsman. P. HeckstallSinith and E. du Boulay. Second Edition, Rezised. I5s. net.

\section{The Connoisseur's Library}

\section{With mumerous Illustrations. Wide Royal 8vo. 25s. net each volume}

Erglish Furniture. F. S. Robinson.

English Coloured Books. Martin Hardie. Etchings. Sir F. Wedmore Second Edition.

European Enamels. Henry H. Cunyng. hame.

Glass. Edward Dillon.

Goldinthit and Silversmiths' Work. Nelson Dawson. Second Edition.

Illuminated Manuscirts. J. A. Herbert. Second Edition.
Ivories. Alfred Maskell.

Jewellery. H. Clifford Smith. Second Edition.

Mezzotints. Cyril Davenport.

Miniatures. Dudley Heath.

Porcelain. Edward Dillon.

Fine Books. A. W. Pollard.

Seals. Walter de Gray Birch.

Wood Sculpture. Alfred Maskell. Seconś Edition. 


\section{Handbooks of English Church History}

\section{Edited by J. H. BURN. Crown Svo. 2s. 6d. net each vointme}

The Foundations of the English CHURCh. J. H. Maude.

Tine Saxon Church and the Norman Conquest. C. T. Cruttwell.

The Medieval Church and the Papacy. A. C. Jemnings.
The Reformation Period. Henry Gee.

The Struggle with Puritanism. Brtice Blaxland.

The Church of England in the Eigh. teenth Century. Alfred Plummer.

\section{Handbooks of Theology}

The Doctrine of the Incarnation. R. L. Ottley. Fifth Edition, Revised. Demy 8vo. I2s. 6 d.

A History of Early Chiristian Doctrine. J. F. Bethune-Baker. Demy 8vo. ros. $6 d$.

An Introduction to the History of Religion. F. B. Jevons. Fifth Edition. Demy 8vo. Ios. $6 d^{\circ}$.
AN INTRODUCTION TO THE HISTORY OF THE Creeds. A. E. Burn. Demy 8zo. Ios. 6d.

The Philosophy of Religion in Eygland and America. Alfred Caldecott. Demy 8vo. Ios. $6 d$.

The XXXIX Articles of the Church of England. Edited by E. C. S. Gibson. Seventh Edition. Demy 8vo. 12s. 6d.

\section{The 'Home Life' Series \\ Illustrated. Demy 8io. 6s. to IOs. 6d. net}

Home Life in America. Katherine G. Bisbey. Second Edition.

Home Life in France. Miss Betham. Edwards. Sixth Edition.

Home Life in Germany. Mrs. A. Sidgwick. Second Edition.

Home Life in Holland. D. S. Meldrum. Second Edition.
Home Life IN ITALy. Lina Duff Gordon. Second Edition.

Home Life in Norway. H. K. Daniels. Second Edition.

Home Life in Russia. A. S. Rappoport.

Home Life in Spain. S. L. Bensusan. Second Edition.

\section{The Illustrated Pocket Library of Plain and Coloured Books} Ficap. 8vo. 3s. 6d. net each volume

\section{WITH COLOURED ILLUSTRATIONS}

The Life and Death of John Mytron, EsQ. Nimrod. Fifth Edition.

The Life of a Sportsman. Nimrod.

\section{Handley Cross. R. S. Surtees. Fourth} Edition.

Mr. Sponge's Sporting Tour. R. S. Surtecs. Second Edition.

Jokrocks's Jaunts and Jollities. R. S. Surtees. Third Edition.

Aš MamaA. R. S. Surtees.
The Analysis of the Hunting Field. R. S. Surtees.

The Tour of Dr. Syntax in SEarch of tue Picturesque. William Combe.

The Tour of Dr. Syntax in Search of Consolation. William Combe.

The Timrd Tour of Dr. Syntax in Search OF A Wili. William Combe.

Life in London. Pierce Egan.

\section{WITH PLAIN ILLUSTRATIONS}

Tiu Grave: A Poem. Robert Blair.

Illustrations of THE BOOK OF JOB. It vented and Engraved by William Blake. 


\section{Leaders of Religion}

\section{Edited by H. C. BEECHING. With Portraits}

Crown Swo. 2s. net each volume

Cardinal Newman. R. H. Hutton.

JOHN WESLEY. J. H. Overton.

Bishop Wirberforce. G. W. Daniell.

Cardinal Manning. A. W. Hutton.

Ciiarles Simeon. H. C. G. Moule.

Jонn Knox. F. MacCunn. Second Edition.

JohN Howe. R. F. Horton.

Thomas Ken. F. A. Clarke.

George Fox, the Quaker. T. Hodgkin.

Third Edition.

JоHN KeBLE. Walter Lock.
Thomas Chalmers. Mrs. Oliphant. Seconz Edition.

Lanceiot Andrewes. R. L. Ottley. Seconit Edition.

Augustine of Canterbury. E. L. Cutts.

William Laud. W. H. Hutton. Fourth Edition.

John Donne. Augustus Jessop.

Thomas Cranmer. A. J. Mason.

Latimer. R. M. and A. J. Carlyle.

Bishop Butler. W. A. Spooner.

\section{The Library of Devotion}

\section{With Introductions and (where necessary) Notes \\ Smalt Poit 82.0, cloth, 2s.; leather, 2s. 6d. net each volume}

The Confessions of St. Augustine. Eighth Edition.

The IMitation of Christ. Sixth Edition.

The Christian Year. Fifth Edition.

LYRA InNOCENTIUn. Third Edition.

The Temple. Second Edition.

A Buok of Devotions. Second Edition.

A Serious Call to a Devout and Holy LIFE. Fifth Edition.

A Guide to Eternity.

ThE Inner Way. Second Edition.

ON the Love of God.

The Psalms of David.

Lyra Apostolica.

The Song of Songs.

The Thoughts or Pascal. Second Edition.

A Manual of Consolation from the SAINTS AND FATHERS.

Devotions from tile Apocryitha.

The Spiritual Combat.
The Devotions of St. Anselm.

Bishop Wilson's Sacra Privata.

Grace Abounding to the Chief of Sin. NERS.

Lyra SAcra. A Book of Sacred Verse. Second Edition.

A Day Book from the Saints and Fatheirs.

A LitTle book of Heavenly Wisdom. A Selection from the English Mystics.

Light, LIFE, and Love. A Selection from the German Mystics.

An Intronuction to the Devout Life.

The Little Flowers of the Glorious Messer St. Francis and of his Friaks.

Death and Immortality.

The Spiritual Guide. Second Edition.

DEVOTIONS FOR EVERY DAY IN THE IVEEK and the Great Festivals.

Preces Privatae.

Horae Mrsticae. A Day Book from the Writings of Mystics of Many Nations. 


\section{Little Books on Art}

\section{With many Illusirations. Demy 16 mo. 2s. 6d. net each volume}

Each volume consists of about 200 pages, and contains from 30 to 40 Illustrations, including a Frontispiece in Photogravure

Albrecht Dürer. L. J. Allen.

Arts of JAPAN, THE. E. Dillon. Third Edition.

Bookplates. E. Almack.

Botticelli. Mary L. Bonnor.

Burne-Jones. F. de Lisle.

Cellini. R. H. H. Cust.

Christian Srmbolism. Mrs. H. Jenner.

Christ in Art. Mrs. H. Jenner.

Claude. E. Dillon.

Constable. H. W. Tompkins. Second Edition.

Corot. A. Pollard and E. Birnstingl.

Early English Water-Colour. C. E. Hughes.

Enamels. Mrs. N. Dawson. Second Edition.

Frederic Leighton. A. Corkran.

Grorge Romney. G. Paston.

Greek ArT. H. B. Walters. Fourth Edition.
Greuze and Bucher. E. F. Pollard. Holbein. Mrs. G. Fortescue.

Illuminated Manuscripts. J. W. Bradley. Jewellery. C. Davenport. Second Edition. JOHN HORpNER. H. P. K. Skipton.

Sir Joshua Reynolds. J. Sime. Second Edition.

Millet. N. Peacock. Second Edition.

Miniatures. C. Davenport. Second Edition. Our Lady in ARt. Mrs. H. Jenner.

RAPHAEl. A. R. Dryhurst.

Rodin. Muriel Ciolkowska.

Turner. F. Tyrrell-Gill.

VANDYCK. M. G. Smallwood.

Velazquez. W. Wilberforce and A. R. Gilbert.

WatTs. R. E. D. Sketchley. Second Edition.

\section{The Little Galleries}

\section{Demy i6mo. 2s. 6i. net each volume}

Each volume contains 20 plates in Photogravure, together with a short outline of the life and work of the master to whom the book is devoted

A little Gallery of Reynolds.

A Little Gallery of Romney.
A Little Gallery of Hoppner.

A Little Gallery of Mirllais.

\section{The Little Guides}

With many Illustrations by E. H. New and other artists, and from photographs Small Pott 8vo. Cloth, 2s. 6d. net; leather, 3s. 6\%. net each volume

The main features of these Guides are (I) a handy and charming form ; (2) illus. trations from photographs and by well-known artists; (3) good plans and maps; (4) an adequate but compact presentation of everything that is interesting in the natural features, history, archæology, and architecture of the town or district treated

Cambridge and its Collegrs. $A$. $\mathrm{H}$. Thompson. Third Edition, Revised.

Channel Islands, The. E. E. Bicknell.

English Lakes, The. F. G. Brabant.
IsLe of Wight, Tite. G. Clinch.

London. G. Clinch.

Malvern Country, The. Sir B.C.A. Windle.

North Wales. A. T. Story. 


\section{The Little Guides-continued}

OXFORD AND ITS Colleges. J. Wells. Ninth Edition.

St. Paul's Cathedral. G. Clinch.

Shakespeare's Country. Sir B. C. A. Windle. Fifth Edition.

South IVAI.ES. G. W. and J. H. Wade.

Westminster AbBey. G. E. Troutbeck. Second Edition.

Berksilike. F. G. Brabant.

Blckinghamshire. E. S. Roscoe.

Cheshire. IV. M. Gallichan.

Cornwall. A. I. Salmon. Second Edition.

Tiertighire. J. C. Cox.

Devon. S. Baring-Gould. Third Edition.

Torset. F. R. Heath. Second Edition.

DURHAM. J. E. Hodgkin.

Essex. J. C. Cox.

Hamrsuine. J. C. Cox. Second Edition.

Hertfordshire. H. W. Tompkins.

KENT. G. Clinch.

Kerry. C. P. Crane. Second Edition.

Leicestershire and Ruthand. A. Harvey and V. B. Crowther-Beynon.

Middlesex. J. B. Firth.

Monmouthsinke. G. W. and J. H. Wade.
Norfolk. W. A. Dutt. Third Edition, Revised.

Northamptonshine. W. Dry. Second Edition, Revised.

Nortiumberland. J. E. Morris.

NotTinghanshire. L. Guilford.

OXFORDSIIRE. F. G. Brahant.

Siropshire. J. E. Auden.

Somerset. G. W. and J. H. Wade. Second Edition.

Staffordshire. C. Masefield.

SuFfolk. W. A. Dutt.

Surrey. J. C. Cox.

Sussex. F. G. Brabant. Third Edition.

WILTSHIRE. F. R. Heath.

Yorkshire, The EAst Riding. J. E. Morris.

Yorkshirf, The North Riding. J. H. Morris.

Yorkshire, TIIE West Riding. J. E. Morris. Cloth, 3s. 6d. net; lecther, 4s. 6d. net.

Brittany. S. Baring-Gould.

NoRmandy. C. Scudamore.

Rome. C. G. Ellaby.

Sicily. F. H. Jackson.

\section{The Little Library}

With Introduction, Notes, and Photogravure Frontispieces

Small Pott 8vo. Each Volume, cloth, is. 6d. net

Anon. A LITTLE BOOK OF ENGLISH LYRICS. Second Edition.

Austen (Jane). PRIDE AND PREJU. DICE. Two Volumes.

NORTHANGER ABBEY.

Bacon (Francis). THE ESSAYS OF LORD BACON.

Barham (R. H.). THE INGOLDSBY LEGENDS. Truo Volumes.

Barnett (Annle). A LITTLE BOOK OF ENGIISH PROSE.

Beckford (William). THE HISTORY OF THE CALIPH VATHEK.
Blake (WIlliam). SELECTIONS FROM THE WORKS OF WILLIAM BLAKE.

Borrow (George). LAVENGRO. Two Volumes.

THE ROMANY RYE.

Browning (Robert). SELECTIONS FROM THE EARLY POEMS OF ROBERT BROWNING.

Canning (George). SELECTIONS FROM THE ANTI-JACOBIN: With some later Poems by George Canning.

Cowley (Abraham). THE ESSAYS OF ABRAHAM COWLEY. 


\section{The Little Library-continued}

Crabbe (George). SELECTIONS FROM THE POEMS OF GEORGE CRABBE.

Craik (Mrs.). JOHN H A L F AX, GENTLEMAN. Two Volumes.

Crashaw (Fichard). THE ENGLISH POEMS OF RICHARD CRASHAW.

Dante Alighieri. THE INFERNO OF DANTE. Trauslated by H. F. CARY.

THE PURGATORIO OF DANTE. Translated by H. F. CARY.

THE PARADISO OF DANTE. Translated by H. F. CARY.

Darley (Georgo). SEI,ECTIONS FROM THE POEMS OF GEORGE DARLEY.

Dickens(Charles). CHRISTMAS BOOKS. Truo Volumes.

Ferrier (Susan). MARRIAGE. Two l'olumes.

'IHE INHERITANCE. Two Volumes.

Gaskell (firs.). CRANFORD. Second Edition.

Maw thorne (Nathaniel). THE SCARLET LETTER.

Henderson (T. F.). A LITTLE BOOK OF SCOTTISH VERSE.

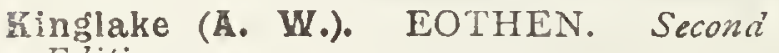
Edition.

Lan!b (Charles). ELIA, AND THE LAST ESSAYS OF ELIA.

Locker (F.). LONDON LYRICS.
Maryell (Andrew). THE POEMS OE ANDREW MARVELL.

Milton (John). THE MINOR POEMS OF JOHN MILTON.

Hoir (D. M.). MANSIE WAUCH.

Nichols (Bowyer). A LITTLE BOOK OF ENGLISH SONNETS.

Smith (Horace and James). REJECTED ADDRESSES.

Sterne (Laurence). A SENTIMENTAL JOURNEY.

Tennyson (Alfred, Lord). THE EARLY POEMS OF ALFRED, LORD TENNY. SON.

IN MEMORIAM.

THE PRINCESS.

MAUD.

Thackeray (U. M.). VANITY FAIR. Three Volumes.

PENDENNIS. Three Volumes.

HENRY ESMIOND.

CHRISTMAS BOOKS.

Iaughan (Henry). THE POEMS OF HENRY VAUGHAN.

Waterhouse (Elizabeth). A L T T LE BOOK OF LIFE AND DEATH. Fourteenth Edition.

Wordsworth (W.). SELECTIONS FROM THE POEMS OF IVILLIAM WORDS. WORTH.

Wordsworth (W.) and coicridge (B. T.). LYRICAL BALLADS. Second Edition.

\section{The Little Quarto Shakespeare}

Edited by W. J. CRAIG. With Introductions and Notes Pott I6mo. 40 Volumes. Leather, price Is. net each volume Mahogany Revolving Boole Case. ros. net

\section{Miniature Library}

Demy 32mo. Leather, is. net each volume

EUphranor: A Dialogue on Youth. Edward / Polonius; or, Wise Saws and Modern In. FitzGerald.

The Life of Edward, Lord Herbert of CherbukY. Written by himself. stances. Edward FitzGerald.

The Rubáiyát of Omar Khayyám. Edward FitzGerald. Fourth Edition. 


\section{The New Library of Medicine}

\section{Edited by C. W. SALEEBY. Demy Szo}

CARE OF THE BODY, THE, F. Cavanagh. Second Edition. 75. 6d. net.

Cimldren of the Nation, The. The Right Hon. Sir John Gorst. Second Edition. ;s. 6d. net.

Diseases of Occupation. Sir Thos. Oliver. Ios. 6d. net. Second Edition.

Drink Proplem, in its Medico-Sociological Aspects, The. Edited by T. N. Kelynack. 7s. $\in$ d. net.

Drugs and the Drug Habit. H. Sainsbury.
Functional Nerve Diseases. A. T. Scho" field. 7 s. 6 . net.

Hygiene of Mind, The. T. S. Clouston. Sixth Edition. $7 s .6 d$. net.

Infant Mortality. Sir George Newman. 7s. 6 d. net.

Prevention of Tuberculosis (ConsumpTION), The. Arthur Newsholme. yas. 6l. net. Second Edition.

Air and Health. Ronald C. Macfie. $7 s .6 \%$. net. Second Edition.

\section{The Now Library of Music}

Edited by ERNEST NEWMAN. Illustrated. Demy 8vo. 7s. 6d. net

Brahms. J. A. Fuller-Maitland. Second | Handel. R. A. Streatfeild. Second Edition Edition.

Hugo Wolf. Ernest Newman.

\section{Oxford Biographies}

Illistrated. Fcap. 8vo. Each volume, cloth, 2s. 6d. net; leather, 3s. 6d. net

Dante Alighieri. Paget Toynbee. Third Edition.

Girolamo Savonarola. E. L. S. Horsburgh. Sixth Edition.

John Howard. E. C. S. Gibson.

Alfred Tennyson. A. C. Benson. Second Edition.

Sir Walter Raleigh. 1. A. Taylor.
Erasmus. E. F. H. Capey.

Robert Burns. T. F. Henderson.

Chatham. A. S. McDowall.

Canning. W. Alison Phillips.

BEACONSFIEI.D. Walter Sichel.

Johann Wolfgang Goethe. H. G. Atkins.

François de FÉnelon. Viscount St. Cyres.

\section{Four plays}

Fcap. 8vo. 2s. net

The Honermoon. A Comedy in Three Acts. Arnold Bennett. Second Edition.

The Great Adventure. A Play of Fancy in Four Acts. Arnold Bennett. Second Edition.

Milestones. Arnold Bennett and Edward Knoblauch. Sixth Edition.
Kismet. Edward Knoblauch. Second Edition.

Typhoon. A Play in Four Acts. Melchior Lengyel. English Version by Laurence Irving. Second Edition.

\section{The States of Italy}

Edited by E. ARMSTRONG and R. LANGTON DOUGLAS

\section{Illustrated. Demy 8vo}
A History of Milan under the Sforza. Cecilia M. Ady: ros. 6 d. net.
A History of Verona. A. M. Allen. a History of Perugia. W. Heywood. izs. 6d. net. 


\title{
whe Westminster Commentaries
}

\author{
General Editor, WALTER LOCK
}

\section{Demy svo}

The Acts of tile Apostles. Edited by R. B. Rackham. Sixth Edition. ros. 6 d.

Tie First Epistle of Paul tie Afostle TO THE Corinthians. Elited by H. L. Goudge. Thive Edition. 6 s.

The Book of Exodus. Edited by A. H. M'Neile. With a Map and 3 Plans. Ios. $6 d$.

The Book of Ezekiel. Edited by H. A. Redpath. Ios. $6 d$.

The Boor of Genesis. Edited, with Introduction and Notes, by S. R. Driver. Ninth Edition. ros. 6d.
ADditions AND CORRECTIONS IN THE SEVENTh and Eighth Editions of the Book of Genesis. S. R. Driver. Is.

The book of the Prophet Isaiar. Edited by G. W. Wade. Ios. $6 d$.

THE BOOK OF Job. Edited by E. C. S. Gib. son. Second Edition. 6s.

The Epistle of St. James. Edited, with Introduction and Notes, by R. J. Knowling. Second Edition. 6s.

\section{The 'Young' Series}

\section{Illustrated. Crown 8vo}

The Young Botanist. W. P. Westell and C. S. Cooper. 3s. 6 a. net.

The Young Carpenter. Cyril Hall. 5s.

The Young Electrician. Hammond Hall. 5s.
The Young Engineer. Hammond Hall. Third Edition. 5 s.

The Young Naturalist. W. P. Westell. Second Edition. 6s.

The Young Ornithologist. W. P. Westell. $5 s$.

\section{Methuen's Shilling Library}

\section{Fcap. 8vo. Is. net}

Blue Bird, The. Maurice Maeterlinck.

${ }^{*}$ Cirarles Dickens. G. K. Chesterton.

* Charmides, and other Poens. Oscar Wilde.

Chitral : The Story of a Minor Siege. Sir G. S. Robertson.

Condition of England, The. G. F. G. Masterman.

De Profundis. Oscar Wilde.

From Midshipman to Field-Marshal. Sir Evelyn Wood, F.M., V.C.

Harvest Home. E. V. Lucas.

Hills and the Sea. Hilaire Belloc.

Huxley, Thomas Henry. P. Chalmers. Mitchell.

Ideal Husband, An. Oscar Wilde.

InTENTIONS. Oscar Wilue.

JiMmY Glover, His Book. James M. Glover.

JOHN Boyes, King OF THE WA.KIKUYU. John Boyes.

LADY Windermere's FAN. Oscar Wilde.

Letters from a Self-made Merchant To HIS Son. George Horace Loriner.
Life of John Ruskin, The. W. G. Collingivood.

Life of Robert Louis Stevenson, The. Graham Balfour.

Life of Tennyson, The. A. C. Benson.

Little of Everytinng, A. E. V. Lucas.

Lord Arthur Savile's Crime. Oscar Wilde.

Lore of ThE Honey-BeE, The. Tickner Edwardes.

Man and the Universe. Sir Oliver Lodge. Mary Magdalene. Maurice Maeterlinck. Old Country Life. S. Baring-Gould.

Oscar Wilde: A Critical Study. Arthur Ransome.

Parish Clerk, The. P. H. Ditchfield.

Selected Poems. Oscar Wilde.

Sevastopol, and other Stories. Leo Tolstoy.

Two Admirals. Admiral John Moresby.

Under Five Reigns. Lady Dorothy Nevill. Vailima Letters. Robert Louis Stevenson. Vicar of Morwenstow, The. S. Baring. Gould. 


\title{
Books for Trayellers
}

\author{
Crown 8vo. 6s. each
}

Each volume contains a number of Illustrations in Colour

Avon and Shakespeare's Country, 'The. A. G. Bradley.

BLACK FOREST, A BOOK OF THE. C. E. Hughes.

Brftons at Hone, The. F. M. Gostling.

Cities of Lombardy, Tile. Edward Hutton.

Cities of Romagna and the Marches,

ThE. Edward Hutton.

Cities of Spain, The. Edward Hutton.

Cities of Umbria, The. Edward Hutton.

Days in Cornwall. C. Lewis Hind.

Florence and Northern Tuscany, with Genoa. Edward Hutton.

LAND of Paruons, The (Brittany). Anatole Le Braz.

Naples. Arthur H. Norway.

Naples Riviera, The. H. M. Vaughan.

New Forest, The. Horace G. Hutchinson.
Norfolk Bkoads, The. W. A. Dutt.

Norway ANd its Fjords. M. A. Wyllie.

RHINe, A BoOk OF THE. S. Baring-Gould.

Rome. Edward Hutton.

Round about Wiltshire. A. G. Bradley.

Scotland or To-day. T. F. Henderson and Francis Watt.

Siena and Southern Tuscany. Edward Hutton.

Shirts of the Great City, The. Mis. A. G. Bell.

Through East Anglia in a Motor Cak. J. E. Vincent.

Venice and Venetia. Edward Hutton.

Wanderer in Florence, A. E. V. Lucas.

Wanderer in Paris, A. E. V. Lucas.

Wanderer in Holland, A. E. V. Lucas.

Wanderer in London, A. E. V. Lucas.

\section{Some Books on Art}

ARMourer AND his Craft, ThE. Charles froulkes. Illustrated. Royal 4 to. $£_{2} 2 s$. net.

ART AND LifE. T. Sturge Moore. Illustrated. Cr. 8vo. 5s. net.

British School, The. An Anecdotal Guide to the Pritish Painters and Paintings in the Nationai Gallery. E. V. Lucas. Illustrated. Fcrp. 8vo. 2s. 6d. net.

* Decorative Iron Work. From the xith to the xvilith Century. Charles ffoulkes. Royal 4to. f2 2 s. net.

Francesco Guardi, 1712-1793. G. A. Simonson. Illustrated. Imperial ${ }_{4}$ to. ¿2 2s. net.

Illustrations OF THE BOOK OF JOB. William Blake. Qunrto. Ei is, net.

John Lucas, Portrait Painter, $1828-1874$. Arthur I.ucas. Illustrated. Imperial $4^{t o .}$ $E_{3} 35$ net.

OLD PAste. A. Beresford Ryley. Illustrated.

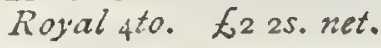

One Hundred Masterpieces of Painting. With an Introduction by R. C. Witt. Hllustrated. Second Edition. Demy 8vo. ros. 6d. net.
One Hundred Masterpieces of Sculpture. With an Introduction by G. F. Hill. Illustrated. Demy 8vo. ros. 6 d. net.

Romney Folio, A. With an Essay by A. B. Chamberlain. Imperial Folio. EI5 I5s. net.

* Royal Academy Lectures on Painting. George Clausen. Hllustrated. Crown 800. 5s, net.

Saints in Art, ThE. Margaret E. Tabor. Illustrated. Second Edition, Revised. Ficap. 8vo. 3 s. 6d. net.

Schools of Painting. Mary Innes. Illus. trated. Cr. 8vo. 5s. net.

Celtic Art in Pagan and Christian Times. J. R. Allen. Illustrated. Second Edition. Demy 820. 7s. 6d. net.

'Classics of ARt.' See page 14.

'The Connoisseur's Library.' See page is.

'Little Books on ARt.' See page i3.

'The Little Galleries.' See page 18. 


\section{Some Books on Italy}

Etruria and Modern Tuscany, Old. Mary I. Cameron. Illustrated. Second Edition. Cr. 8vo. 6s. met.

Fi.ORENCE: Her History and Art to the Fall of the Republic. F. A. Hyett. Demy $8 v 0$. $7 s .6$. net.

Florince, A Wanderer in. E. V. Lucas. Illustrated. Fourth Edition. Cr. 8vo. 6s.

Florence AND her Treasures. H. M. Vaughan. Illustrated. Ficaf.8vo. 5s. net.

Florence, Country Walks about. Edward Hutton. Illustrated. Second Edition. Fcap. 820. 5s. net.

Florence and tile Cities of Northern Tuscany, with Genoa. Edward Hutton. Illustrated. Second Edition. Cr. 8v0. $6 s$.

Lombardy, Tire Cities of. Edward Hutton. Illustrated. $C \% .8 \% 0.6 s$.

Milan under the SForza, A History of. Cecilia M. Ady. Illustrated. Demy $8 v 0$. ros. 6d. net.

NAPLES: Past and Present. A. H. Norway. Illustrated. Third Edition. Cr. 8vo. 6 s.

Napies Riviera, The. H. M. Vaughan. Iilustrated. Second Edition. Cr. 8vo. 6s.

Perugia, A History of. William Heywood. Illustrated. Demy 8vo. I2s. 6d. net.

Rome. Edward Hutton. Illustrated. Third Edition. Cr. 8w0. 6s.

Romagna and the Marches, The Cities of. Edward Hutton. Cr. 8io. 6s.

Roman Pilgrimage, A. R. E. Roberts. Illustrated. Demv8vo. ras. 6et. net.

Rome of the PIllgrims and Martyrs. Ethel Ross Barker. Demy 8\%o. I2s. $6 d$. net.

Rome. C. G. Ellaby. Illustrated. Small Pott 8vo. Cloth, 2s. 6d. net; leather, 3 s. $6 d$. net.

Sicily. F. H. Jackson. Illustrated. Small Fott 8vo. Cloth, 2s.6d. net; leather, 3s. 6 d. net.

Sicily: The New Winter Resort. Douglas Sladen. Illustrated. Second Edition. Cr. 8vo. 5s. met.

Siena and Southern Tuscany. Edward Hutton. Illustrated. Second Edition. Cr. 820. 6s.
Umbria, The Cities of. Edward Hutton. Illustrated. Fifth Edition. Cr. 8vo. $6 s$.

VENICE AND Venetia. Edward Hutton. Illustrated. Cr. 870. $6 s$.

VENICE on FOOT. H. A. Douglas. Illus. trated. Second Eitition. Fcap. 800. 5s. net.

VENICE AND HER TREASURES. H. 1. Douglas. Illustrated. Fcap. 8vo. 5s. net.

Verona, A History of. A. M. Allen. Illustrated. Demy 8zo. r2s. 6d. net.

DANTE AND His ItAly. Lonsdale Ragg. Illustrated. Demy 8vo. i2s. 6d. net.

Dantz Alighieri : His Life and Works. Paget Toynbee. Illustrated. Cr. 8vo. $5 s$. net.

HoME LifE IN ITALY. Lina Duff Gordon. Illustrated. Third Edition. Demy 8zo. ros. $6 d$. net.

LAkes of Northern Italy, The. Richard Bagot. Illustrated. Fcap. 8vo. 5s. net.

Lorenzo the Magnificent. E. L. S. Horsburgh. Illustrated. Second Edition. Demy 8vo. I5s. net.

Medici Popes, The. H. M. Vaughan. Illus. trated. Demy 820. r 5 s. net.

St. Catherine of Siena and her Timfs. By the Author of "Mdlle. Mori." Illustrared. Second Edition. Demy 8ro. 7s. 6d. net.

S. Francis of Assisi, The lives of. Brother Thomas of Celano. Cr. 8vo. $5 s$. net.

Savonarola, Girolano. E. L. S. Horsburgh. Illustrated. $\mathrm{Cr}$. 8ro. 5s. net.

Shelley and His Friends In ITAly. Helen R. Angeli. Illustrated. Demy 8vo. ros. $6 \AA$. net.

Skies Italian: A Little Breviary for Tra. vellers in Italy. Ruth S. Phelps. Fcap. 8vo. 5s. net.

United Italy. F. M. Underwood. Demy 8vo. To.s. 6 d. net.

Wom AN IN I taly. W. Boulting. Illustrated. Demy 8zo. ros. 6d. net. 


\section{PARt III.-A Selection of Works of Fiction}

Albanesi (E. Maria). SUSANNAH AND ONE OTHER. Fourth Edition. Cr. 8vo. 6s.

THE BROWN EYES OF MARY. Third Edition. Cr. Evo. 6s.

I KNOW A MIIDEN. Third Edition. Cr. 8\%o. $6 s$.

THE INVINCIBLE AMELIA; OR, THE Polite ADVENTURESS. Third Edition. Cr. 8vo. $35.6 d$.

THE GLAD HEART. Fifth Edition. Cr. 8\%o. $6 s$.

OLIVIA MARY. Fourth Edition. Cr. 8चo. 6s.

THE BELOVED ENEMY. Second Edition. Cr. 8vo. 6s.

Bagot (Richard). A ROMAN MYSTERY. Third Edition Cr. 8vo. 6s.

THE PASSPORT. Fourth Ecition. Cr. $800.6 s$.

ANTHONY CUTHEERT. Fourth Edition. Cr. 8*o. 6s.

LOVE'S PROXY. Cr. 8vo. 6s.

DONNA DIANA. Second Edition. Cr. 8v0. $6 s$.

CASTING OF NETS. Twelfth Edition. Cr. 8ro. 6s.

'THE HOUSE OF SERRAVALLE. Third Edition. Cr. 8ro. 6 s.

DARNELEY PLACE. Second Edition. Cr. 3vo. 6s.

Bailey (H. C.). STORM AND TREASURE. Thira Edition. Cr. 8vo. 6s.

THE LONELY QUEEN. Third Edition. Cr. 8vo. 6s.

THE SEA CAPTAIN. Cr. 8vo. 6s.

Baring-Gould (g.). IN THE ROAR OF THE SEA. Eighth Edition. Cr. 8vo. 6s.

MARGERY OF QUETHER. Second Edition. Cr. 8vo. 6 s.

THE QUEEN OF LOVE. Fifth Edition. Cr. 8v0. $6 s$.

JACQUETTA. Third Edition. Cr. 8vo. 6s. KITTY ALONE. Fifth Edition. Cr. 8v0. 6s. NOEMI. Illustrated. Fourth Edition. Cr. 8vo. $6 s$.

THE BROOM-SQUIRE. Illustrated. Fifth Edition. Cr. 800. 6 s.
PLADYS OF THE STEWPONEY. Illustrated. Second Edition. Cr. 8vo. 6s.

PABO THE PRIEST. Cr. 8vo. $6 s$.

WINEFRED. Illustrated. Second Edition. Cr. 8ro. 6s.

ROYAL GEORGIE. Illustrated. Cr. 8wo. 6s. IN DEWISLAND. Second Edition. Cr. 8vo. $6 s$.

MRS. CURGENVEN OF CURGENVEN. Fifth Edition. Cr. $8 v 0$. $6 s$.

Barr (Robert). IN THE MIDST OF ALARMS. Third Edition. Cr. 8vo. $6 s$.

THE COUNTESS TEKLA. Fifth Edition. Cr. 8vo. 6 s.

THE MUTABIE MANY. Third Edition. Cr. 8vo. 6s.

Begble (Harold). THE CURIOUS AND DIVERTING ADVENTURES OF SIR JOHN SPARROW, BART.; OR, THE Progress of an OPEN MIND. Secoml Edition. Cr. 8vo. 6s.

Belloc (H.). EMMANUEL BURDEN, MERCHANT. Illustrated. Second Edition. Cr. 8vo. $6 s$.

A CHANGE IN THE CABINET. Third Edition. Cr. 8ro. 6 .

Bennett (Ārnold). CLAYHANGER. Eleventh Edition. Cr. 8vo. $6 \mathrm{~s}$.

THE CARD. Sirth Edition. Cr. 8vo. 6s. HILDA LESSWAYS. Serentle Edition. Cr. 8vo. 6s.

BURIED ALIVE. Third Edition. Cr. 8vo. 6s.

A MAN FROM THE NORTH. Third Edition. Cr. 8zo. $6 s$.

THE MATADOR OF THE FIVE TOWNS. Second Edition. Cr. 8vo. $6 s$.

THE REGENT: A FIVE. Tows STORY op ADVENTURE IN LONDON. Third Edition. Cr. 8ะo. 6s.

ANNA OF THE FIVE TOWNS. Fcap. 8vo. Is. net.

TERESA OF WATLING STREET. Fcap. 8vo. Is. net.

Benson (E, G.). DODO : A DETAIL OF TIE DAY. Sixteenth Edition. Cr. $8 v o$. 6s. 
Birmingham (George A.). S P A N I S H GOLD. Sixth Edition. Cr. Svo. 6s. Also Fcap. 80o. is. net.

THE SEARCH PARTY. Sixth Edition. Cr. 8vo. 6s.

Also Fcrp. 8zo. is. net.

LALAGE'S LOVERS. Third Edition. Cr. 8vo. 6s.

THE ADVENTURES OF DR. WHITTY. Fourth Edition. Cr. 8vo. $6 s$.

Bowen (Marjorie). I WIL L MAINTAIN Eighth Edition. Cr. 8vo. $6 s$.

DEFENDER OF THE FAITH. Seventh Edition. $\mathrm{Cr} .800$. $6 s$.

A KNIGHT OF SPAIN. Third Edition. Cr. 800. 6s.

THE QUEST OF GLORY. Third Edition. Cr. 8vo. 6s.

GOD AND THE KING. Fifth Edition. Cr. 8vo. 6s.

THE GOVERNOR OF ENGLAND. Second Edition. Cr. 8vo. 6s.

Castle (Agnes and Egerton). THE GOLDEN BARRIER. C $\%$. $\%$. 6s.

* Chesterton (G. K.). THE FLYING INN. Cr. 8vo. 6s.

Clifford (Mrs. W. K.). THE GETTING WELL OF DOROTHY. Illustrated. Third Edition. Cr. 8vo. 3s. 6d.

Conrad (Joseph). THE SECRET AGENT: A Simple Tale. Fourth Edition. Cr. $8 v o$. $6 s$.

A SET OF SIX. Fourth Edition. Cr.8vo. $6 s$.

UNDER WESTERN EYES. Second Edition. Cr. 8vo. 6s.

CHANCE. Cr. $8 v 0.6 s$.

Conyers (Dorothea). SALLY. Fourth Edition. Cr. 8vo. 6s.

SANDY MARRIED. Third Edition. Cr. 8vo. 6s.

Corelli (Marie). A ROMANCE OF TWO WORLDS. Thirty-Second Edition. Cr. 8vo. $6 s$.

VENDETTA; OR, THE STORY OF ONE FORGOTIEN. Thirtieth Edition. Cr. 8vo. $6 s$.

THELMA: A Norwegian Princess. Forty-third Edition. Cr. 8vo. $6 s$.

ARDATH: The Story of a Dead Self. Truenty-first Edition. Cr. 8vo. 6 s.

THE SOUL OF LILITH. Seventecnth Edition. Cr. 8vo. $6 s$.

WORMWOOD: A DRAMA OF PARIS. Ninetecnth Edition. Cr. 8vo. $6 s$.

BARABBAS: A DREAM OF TIE WORLD'S TRAGEDY. Forty-sixth Edition. Cr. 8vo. $6 . s$.

THE SORROWS OF SATAN. Fiftyeighth Edition. Cr. 8vo. 6.s.

THE MASTER-CHRISTIAN. Fourteenth Edition. I7gth Thousand. Cr. 8vo. 6s.

TEMPORAL POWER: A STUDY IN SUPREMACY. Second Edition. rsoth Thousand. Cr. 8vo. 6s.
GOD'S GOOD MAN: A SIMPle Love STORY. Sixteenth Edition. I54th Thousand. Cr. 8ro. 6s.

HOLY ORDERS: ThE TRAgEDY OF A Quiet LIFE. Second Edition. I2oth Thousand. Cr. 8vo. 6s.

THE MIGHTY ATOM. Twenty-ninth Edition. Cr. 8vo. $6 s$.

Also Fcap. 8vo. is. net.

BOY : A SкEтcH. Thirtecnth Edition. Cr. 8zo. 6s. Also Fcap. 8vo. Is. net.

CAMEOS. Fourteenth Edition. Cr. Sz'o. $6 s$.

THE LIFE EVERLASTING. Sixth Edition. Cr. 8vo. $6 s$.

JANE : A Social Incident. Fcap. Evo. Is. net.

Crockett (S. R.). LOCHINVAR. Illustrated. Thivd Edition. Cr. 8vo. 6s.

THE STANDARD BEARER. Second Edition. Cr. 800. 6 s.

Croker (B. M.). THE OLD CANTON. MENT. Second Edition. Cr. 8vo. $6 s$.

JOHANNA. Second Edition. Cr. 8vo. $6 s$. THE HAPPY VALLEY. Fourth Edition. Cr. 8vo. 6s.

A NINE DAYS' WONDER. Fourth Edi. tion. Cr. 8vo. $6 s$.

PEGGY OF THE BARTONS. Seventh Edition. Cr. 8vo. 6s.

ANGEL. Fifth Edition. Cr. 8vo. $6 s$.

KATHERINE THE ARROGANT. Screrth Edition. Cr. 8vo. 6.s.

BABES IN THE WOOD. Fourth Edition. Cr. 8vo. $6 s$.

* Danby(Frank). JOSEPH IN JEOPARDY. Fcap. 8\%0. Is. net.

Doyle (Sir A. Conan). ROUND THE RED LAMP. Truelfth Edition. Cr. 8vo. $6 \mathrm{~s}$. Also Fcap. Svo. Is. nct.

Drake (Maurice). $\mathrm{WO}_{2}$. Fifth Editio\%. Cr. 8vo. 6s.

Findlater (J. H.). THE GREEN GRAVES OF BALGOWRIE. Fiftl Edition. $C r$. $8210.6 s$.

THE IADDER TO THE STARS. Secont Edition. Cr. 8vo. $6 s$.

Findlater (Mary). A NARROW WAY. Fourth Edition. Cr. 8alo. 6s.

THE ROSE OF JOY. Third Edition. Cr. 8vo. 6s.

A BLIND BIRD'S NEST. Illustrated. Second Edition. Cr. 8v0. $6 s$.

Fry (B. and C. B.). A MOTHER'S SON. Fifth Edition. Cr. 8vo. 6 s.

Harraden (Beatrice). I N V ARYING MOODS. Fourteenth Edition. Cr. 8vo. 6r. HILDA STRAFFORD and THE REMIT. TANCE MAN. Twelfth Edition. Cr. $8 v 0.6 s$.

INTERPLAY. Fifth Edition. Cr.8vo. $6 s$ 
Hauptmann (Gerhart). THE FOOL IN CHRIST : EMMANUEL QUINT. Translated by Thomas Seltzer. Cr. 8vo. $6 s$.

Hichens (Robert). THE PROPHET OF BERKELEY SQUARE. Second Edition. Cr. 8vo. 6s.

TONGUES OF CONSCIENCE. Third Edition. Cr. 8vo. ós.

FELIX: Three Years in a Life. Tenth Edition. Cr. 8vo. 6 s.

THE WOMAN WITH THE FAN. Eighth Edition. Cr. 8vo. 6s. Also Fcap. 8vo. Is. net.

BYEWAYS. Cr. 8vo. $6 s$.

THE GARDEN OF ALLAH. Treenty. second Edition. Cr. 8vo. 6s.

THE BLACK SPANIEL. Cr. 8ro. $6 s$.

THE CALL OF THE BLOOD. Eighth Edition. Cr. 8vo. 6s.

BARBARY SHEEP. Second Edition. Cr. 8vo. $3 s .6 d$.

Also Ficap. 8vo. Is. net.

THE DWELLER ON THE THRESHOLD. Cr. 8vo. $6 s$.

THE WAY OF AMBITION. Fourth Edition. Cr. 8vo. 6s.

Hope (Anthony). THE GOD IN THE CAR. Eleventh Edition. Cr. 8vo. 6s.

A CHANGE OF AIR. Sixth Edition. Cr. 8zo. $6 s$.

A MAN OF MARK. Seventh Edition. Cr. 8vo. $6 s$.

THE CHRONICLES OF COUNT AN. TONIO. Sixth Edition. Cr.8vo. $6 s$.

PHROSO. Illustrated. Ninth Edition. Cr. 8vo. $6 s$.

SIMON DALE. Illustrated. Ninth Edition. Cr. 8vo. 6s.

THE KING'S MIRROR. Fifth Edition. Cr. 8vo. 6s.

QUISANTE.. Fourth Edition. Cr. 8vo. $6 s$. THE DOLLY DIALOGUES. Cr.8vo. $6 s$. TALES OF TWO PEOPLE. Third Edition. $\mathrm{Cr}$.8vo. 6s.

A SERVANT OF THE PUBLIC. Illustrated. Sixth Edition. Cr. 8vo. $6 s$.

THE GREAT MISS DRIVER. Fourth Edition. Cr. 8vo. 6s.

MRS. MAXON PROTESTS. Third Edition. Cr. 8vo. 6s.

Hutten (Baroness yon). THE HALO. Fifth Edition. Cr. 8vo. 6 s. Also Fcap. 8vo. Is. net.

'The Inner Shrine' (Author of). THE WILD OLIVE. Third Edition. Cr.8vo. 6.s.

THE STREET CALLED STRAIGHT. Fourth Edition. Cr. 8vo. 6 s.

THE WAY HOME. Second Edition. Cr. 8थo. $6 s$.
Jacobs (W. W.). MANY CARGOES. Thirty-third Edition. Cr. 8vo. 3s. 6d. Also Illustrated in colour. Demy 8vo. 7 s. 6 d. net.

SEA URCHINS. Seventeenth Edition. Cr. 8vo. $3 s .6 d$.

A MASTER OF CRAFT. Illustrated. Tenth Edition. Cr. 8vo. 3s. 6al.

LIGHT FREIGHTS. Illustrated. Elevent/i Edition. Cr. 8vo. 3s. 6 d.

Also Fcap. 8vo. is. net.

THE SKIPPER'S WOOING. Eleventh Edition. Cr. 8vo. $3 s .6 d$.

AT SUNWICH PORT. Illu-trated. Tenth Edition. Cr. 8vo. 3s. 6d.

DIALSTONE LANE. Illustrated. Eighth Edition. Cr. 8vo. 3s. 6d.

ODD CRAFT. Illustrated. Fifte Edition. Cr. 8vo. 3s. $6 d$.

THE LADY OF THE BARGE. Illustrated Ninth Edition. Cr. 8vo. 3 s. 6\%.

SALTHAVEN. Illustrated. Third Edition. Cr. 8vo. 3s. 6a.

SAILORS' KNOTS. Illustrated. Fifti Edition. Cr. 8vo. 3s. 6d.

SHORT CRUISES. Third Edition. $\mathrm{Cr}$. 8vo. 3s. $6 d$.

James (Henry). THE GOLDEN BOWL. Third Edition. Cr. 8vo. 6s.

Le Queux(William). THE HUNCHBACK OF WESTMINSTER. Third Edition. Cr. 8vo. 6s.

THE CLOSED BOOK. Third Edition. Cr. 8zo. 6s.

THE VALLEY OF THE SHADOW. Illustrated. Third Edition. Cr.8vo. 6s.

BEHIND THE THRONE. Third Edition. Cr. 8vo. 6s.

London (Jack). WHITE FANG. Nints Edition. Cr. 8vo. $6 s$.

Lowndes (Mrs. Belloc). THE CHINK IN THE ARMOUR. Fourth Edition. Cr. 8vo. 6s. net.

MARY PECHELL. Second Edition. Cr. 8vo. $6 s$.

STUDIES IN LOVE AND IN TERROR. Second Edition. Cr. 8vo. 6 s.

THE LODGER. Crozen 8vo. $6 s$.

Lucas (E. Y.). LISTENER'S LURE: AN Oblique Narration. Ninth Edition Fcap. 8vo. 5s.

OVER BEMERTON'S: AN EASYGOING. Chronicle. Tenth Edition. Ficap. 8vo. 5 s.

MR. INGLESIDE. Ninth Edition. Fap. 8vo. $5 s$.

LONDON LAVENDER. Sixth Edition. Fcap. 8vo. 5s. 
Lyall (Edna). DERRICK VAUGHAN, NOVELIST. 44th Thousand. Cr. 8vo. 35.62 .

Macnaughtan (3.). THE FORTUNE OF CHRISTINA M'NAB. Sixth Edition. Cr. 8vo. 2s. net.

PETER AND JANE. Fourth Edition. Cr. 8vo. 6s.

Malet (Lucas). A COUNSEL OF PER. FECTION. Second Edition. Cr. 8vo. 6s.

COLONEL ENDERBY'S WIFE. Sixth Edition. Cr. Svo. $t s$.

THE HISTORY OF SIR RICHARD CALMADY: A Romance. Ninth Edition. Cr. 8\%o. 6s.

THE WAGES OF SIN. Sixteenth Edition. Cr. 8\%o. ós.

THE CARISSIMA. Fifth Edition. Cr. 8zo. $6 s$.

THE GATELESS BARRIER. Fifth Edition. Cr. 8zo. $6 s$.

Mason (A. W. W.). CLEMENTINA. Illustrated. Eighth Edition. Cr.8vo. 6 s.

Max SENGER. Third Edition. Cr. 8vo. bs.

VIVIEN. Tauelftir Eutition. Cr. 8ro. 6s.

THE GUARDED FLAME. Seventh Edition. $C_{r} .820 .6 s$.

Also Fias. 8z'o. is, net.

ODD LENGTHS. Second Edition. Cr. 8vo. $6 s$.

HILL RISE. Fourth Edition. Cr. 8vo. 6s. Also fickp. 8vo. is. net.

THE COUNTESS OF MAYBURY: BETwEen YOU AND I. Fourth Edition. Cr. 8vo. $6 s$.

THE REST CURE. Fourth Edition. Cr. 8vo. 6s.

Hilne (A. A.). THE DAY'S PLAY. Fourth Edition. Cr. 8vo. 6s.

THE HOLIDAY ROUND. Second Edition. Cr. 8vo. 6s.

Montague (C. E.). A HIND LET LOOSE. Third Edition. Cr. 8vo. $6 s$.

THE MORNING'S WAR. Cr. 8zo. 6s.

Morrison (Arthur). TALES OF MEAN STREETS. Seventh Edition. Cr.8vo. $6 s$. Also Fars. 8ro. Is, net.

A CHILD OF THE JAGO. Sixth Edition. Cr. 8zo. 6s.

THE HOLE IN THE WALL. Fourth Edition. Cr. 8vo. $6 s$.

DIVERS VANITIES. Cr. 8vo. 6s.

olliwant (Aifred). OWD BOB, THE GREY DOG OF KENMUIR. With a Frontispiece. Tavelfth Edition. Cr. 8vo. 6s.
THE TAMING OF JOHN BLUNT. Second Edition. Cr. 8 vo. $6 \mathrm{~s}$.

THE ROYAL ROAD. Second Edition. Cr. 8vo. 6s.

Onions (Oliver). GOOD BOY SELDOM: A Romance of Advertisement. Second Edition. Cr.8vo. 6 s.

THE TWO KISSES. Cr. $3 v o .6 s$.

Oppenheim (E. Phillips). MASTER OF MEN. Fifth Edition. Cr. 8vo. $6 s$.

THE MISSING DELORA. Illustrated. Fourth Edition. Cr. 8vo. 6 s.

Also Fcap. 8vo. is. net.

Orczy (Baroness). FIRE IN STUBBLE Fifth Edition. Cr. 8vo. 6 s.

Also Fcap. 8vo. is. net.

Oxenham (John). A WEAVER OF WEBS. Illustrated. Fifth Edition. Cr. 8vo. $6 s$.

THE GATE OF THE DESERT. Eighth Edition. Cr. 8vo. 6 s.

*Also Fcap. 8vo. is. net.

PROFIT AND LOSS. Fourth Edition. Cr. 8ro. $6 s$.

THE LONG ROAD. Fourth Edition. Cr. 8vo. $6 s$.

Also Fcap. 8vo. is. net.

THE SONG OF HYACINTH, AND OTHER STORIES. Second Edition. Cr. 8vo. $6 s$.

MY LADY OF SHADOWS. Fourth Edition. Cr. 8vo. 6s.

LAURISTONS. Fourth Edition. Cr. 8vo. $6 s$.

THE COIL OF CARNE. Sixth Editioi. Cr. 8vo. 6s.

THE QUEST OF THE GOLDEN ROSE. Fourth Edition. Cr.8vo. 6.s.

MARY ALL-ALONE. Third Edition. Cr. 8vo. $6 s$.

Parker (Gilbert). PIERRE AND HIS PEOPLE. Seventh Edition. Cr. 8vo. 6s.

MRS. FALCHION. Fifth Edition. $\mathrm{Cr}$. 8vo. $6 s$.

THE TRANSLATION OF A SAVAGE. Fourth Edition. Cr. 8vo. 6s.

THE TRAIL OF THE SWORD. Illustrated. Tenth Edition. Cr.8vo. $6 s$.

WHEN VALMOND CAME TO PONTIAC: The Story of a Lost Napoleon. Seventh Edition. Cr. 8vo. 6s.

AN ADVENTURER OF THE NORTH: The Last Adventures OF 'Pretty Pierre.' Fifth Edition. Cr. 8vo. $6 s$.

THE SEATS OF THE MIGHTY. Illustrated. Nineteenth Edition. Cr. 8vo. 6s.

THE BATTLE OF THE STRONG: A ROMANCE OF Two KINGDOMS. Illustrated. Seventh Edition. Cr. 8vo. 6s. 
THE POMP OF THE LAVILETTES. Third Edition. Cr. 8vo. 3s. 6 d.

NORTHERN LIGHTS. Fourti Edition. Cr. 8vo. 6s.

THE JUDGMENT HOUSE. Cr. 8vo. $6 s$.

Pasture (Mrs. Henry de la). THE TYRANT. Fourth Edition. Cr. 8vo. 6s. Also ficap. 8vo. is. net.

Pemberton (Max). THE FOOTSTEPS OF A THRONE. Illustrated. Fourth Edition. Cr. 8vo. 6s.

I CROWN THEE KING. Illustrated. Cr. 8vo. 6s.

LOVE THE HARVESTER: A STORY of THE SHIRES. Illustrated. Third Edition. Cr. 8vo. 3s. 6d.

THE MYSTERY OF THE GREEN HEART. Fifth Edition. Cr. 8vo. 2s. net

Perrin (Alice). THE CHARM. Fifth Edition. Cr. 8vo. 6s.

Also Fcap. 8vo. is. net.

THE ANGLO.INDIANS. Sixt/2 Edition. Cr. 800. 6s.

Fhillpotts (Eden). LYING PROPHETS. Third Edition. Cr. 820. 6s.

CHILDREN OF THE MIST. Sixth Edition. Cr. 8vo. 6 s.

THE HUMAN BOY. With a Frontispiece. Serenth Edition. Cr. 8vo. $6 s$.

SONS OF THE MORNING. Second Edition. Cr. 8vo. 6s.

THE RIVER. Fourth Edition. Cr. 8ro. $6 s$. THE AMERICAN PRISONER. Fourth Edition. Cr. 8vo. $6 s$.

KNOCK AT A VENTURE. Third Edition. Cr. 8vo. 6s.

THE PORTREEVE. Fourth Edition. Cr. $8 \approx 0.6 s$.

'THE FOACHER'S WIFE. Second Eciition. Cr. 820. 6s.

'THESTRIKING HOURS. Second Edition. Cr. 8v0. $6 s$.

DEMETER'S DAUGHTER. Third Edition. Cr. 8vo. 6s.

THE SECRET WOMAN. Fcas. 8vo. Is. net.

Pickthall (Marmaduke). SAÏD, THE FISHERMAN. Eighth Edition. Cr. 8vo. 6s.

Also Fcap. 8vo. is. net.

' Q' (A. T. Quiller-Couch). THE MAYOR OF TROY. Fourth Edition. Cr. 8vo. 6s. MERRY-GARDEN AND OTHER STORIES. Cr. 8vo. 6s.

MAJOR VIGOUREUX. Third Edition. Cr. छvo. 6s.
Ridge (WY. Pett). ERB. Second Edition. Cr. 820. 65 .

A SON OF THE STATE. Third Ediion. Cr. 8vo. 3s. $6 \pi$.

A BREAKER OF LAWS. A New Edition. Cr. 800. 3s. 6i.

MRS. GALIR'S IJUSINESS. Illustrated. Second fidition. Cr. Ezo. Gs.

THE WICKHAMSES. Funsth Edition. Cr. 800. 6s.

SPLENDID BROTHER. Funth Edition. Cr. 8vo. $6 s$.

Also ficap. 8ro. Is. net.

NINE IO SIX-THIRII. Third Edition. Cr. 8चo. $6 s$.

THANKS TO SANDERSON. Second Edition. Cr. 8vo. $6 s$.

DEVOTED SPARKES. Seconi Edition. Cr. 820. 6s.

THE REMINGTON SENTENCE. $c \%$ 8vo. $6 s$.

Russell (W. Clank). MASTER ROCKAFELLAR'S VOYAGE, Illustraced. Fourth Edition. Cr. 8vo. 3s. 5d.

Sidgwick (Mrs. Alfreci). THE KINS. MAN. Illustrated. Firit Eition. C\%. 8vo. $6 s$.

THE LANTERN.BE.1RERS. Third Edition. Cr. 8vo. 65 .

THE SEVERINS. Sixth Edition. Cr. 8vo. $6 s$. Also Fcap. 8vo. Is. niet.

ANTHEA'S GUEST. Fourth Edition. Cr. 8v0. $6 s$.

LAMORNA. Third Eitition. Cr. 8vo. 6s. BELOW STAIRS. Second Edition. Cr. 8vo. $6 s$.

Snaith (J. C.). THE PRINCIPAL GIRL. Second Eqition. Cr. 8zo. 6s.

AN AFFAIR OF STATE. Secona Edition. Cr. 8vo. 6s.

Someryille (E. E.) and Ross (Martin). DAN RUSSEL 'THI FOX. Illustrated. Seventh Edition. Cr.8vo. 6s. Also Fcap. 8vo. Is. net.

Thurston (E. Temple). MIRAGE. Fourth Edition. Cr. 8vo. 6s.

Also Ficap. 8vo. Is, net.

Watson (H. B. Marriott). ALISE OF ASTRA. Thind Edition. Cr. Evo. 6s.

THE BIG FISH. Third Edition. Cr. 8ro. $6 s$.

Webling (Peggy). THE STORY OF VIRGINIA PERFECI. Third Edition Cr. 8vo. 6s. Also Ficap. 8vo. is, net. 
THE SPIRIT OF MIRTH. Sixth Edition. Cr. 8vo. 6s.

FELIX CHRISTIE. Third Edition. Cr. 8zo. 6s.

THE PEARL STRINGER. Third Edition. Cr. Ẽio. 6s.

Westrup (Nargaret) (Mrs. W. Sydney Stacey). TIDE MARKS. Second Edition. Cr. 8vo. 6s.

Weyman (Stanley). UNDER THE RED ROBE. Illustrated. Truenty-trird Eilition. Cr. 8vo. 6 s.

Also Ficap. 8vo. is. net.

Whitby (Beatrice). ROSAMUND. Second Edition. Cr. 8io. 6s.

Williamson (C. N. and A. M.). THE LIGHTNING CONDUCTOR: The Strange Adventures of a Motor Car. Illus. trated. Tiventy-first Edition. Cr. 8vo. 6s. Also Cr. 8vo. Is. net.

THE PRINCESS PASSES: A RomancE of A Motor. Illustrated. Ninth Edition. Cr. 8vo. 6s.

LADY BETTY ACROSS THE WATER. Eleventh Edition. Cr. 8vo. 6s.

Also Ficap. 8vo. is. net.
THE BOTOR CHAPERCN. Illustrated. Eighth Edition. Cr. 8vo. 6 s.

*Also ficap. 8vo. is. net.

THE CAR OF DESTINY. Illustrated. Seventh Edition. Cr. 8vo. 6 s.

MY FRIEND THE CHAUFFEUR. Illustrated. Truelfth Edition. Cr. 8vo. 6s.

SCARLET RUNNER. Illustrated. Third Edition. Cr. 8vo. 6s.

SET IN SILVER. Illustrated. Fourt/s Edition. Cr.8vo. $6 s$.

LORD LOVELAND DISCOVERS AMERICA. Second Edition. Cr. 8vo. $6 s$.

TIJE GOLDEN SILENCE. Sixt/z Edition. Cr. 87\%. 6s.

THE GUESTS OF HERCULES. Trira Edition. Cr. 8vo. 6 s.

THE HEATHER MOON. Fifth Edition. Cr. 8vo. 6s.

THE LOVE PIRATE. Illustrated. Secona Edition. Cr. 8vo. 6 s.

THE DEMON. Fcap. 8vo. rs. net.

Wyllarde (Dolf). THE PATHWAY OF THE PIONEER (Nous Autres). Si.xth Edition. Cr. 8vo. 6s.

\title{
Books for Boys and Girls
}

Illustrated. Crown Svo. 3s. 6d.

Geting IVele of Dokorhy, The. Mrs. W. K. Clifford.

Girl of the Peofle, A. L. T. Meade.

Hepsy Gipsy. L. T. Meade. 2s. $6 a$.

Honourable Miss, Trie. L. T. Meade.

Master Rockafellar's Vovagis. W. Clatk Russell.
Orly a Guard-Room Dog. Edith E.
Cuthell. Red Grange, The. Mrs. Molesworth.

Syd Belton: The Boy who would not go to Sen. G. Manville Fenn.

There was once a Prince. Mrs. M. E. Mann.

\section{Methuen's Shilling Noxels}

\author{
Fiap. Svo. Is. net
}

Anna of the Five Towns. Arnold Bennett. Barbary Sheep. Robert Hichens.

* Botor Chaperon, The. C. N. \& A. M. Williamson.

Boy. Marie Corelli.

Charm, The. Alice Perrin.

Dan Russel the Fox. E. CE. Somerville and Martin Ross.
Denon, The. C. N. and A. M. Williamson Fire in Stubrle. Baroness Orczy.

*Gate of Desert, The. John Oxenham. Guarded Flame, The. W. B. Maxweil. Halo, Tre. Baroness von Autten. Hilz Rise. W. I. Maxwell. JANE. Maric Corelli. 


\section{Methuen's Shilling Noyels-continued.}

* Joseph in Jeopardy. Frank Danuy.

Lady Betty Across the Water. C. N. and A. M. Williamson.

Light Freights. W. W. Jacobs.

Long Road, The. John Oxenham.

Mighty Atom, The. Marie Corelli.

AIrage. E. Temple Thurston.

Missing Delora, The. E. Phillips Oppenheim.

Round the Red Lamp. Sir A. Conan Doyle.

SaÍd, the Fishermax. Marmaduke Pickthall.
Search Party, The. G. A. Birmingham. Secret Womax, The. Eden Phillpots. Severins, The. Mrs. Alfred Sidgwick. Spanish Gold. G. A. Birmingham. Splendid Brother. W. Pett Ridge. Tales of Mean Streets. Arthur Morrison. Teresa of Watling Street. Amold Bennett.

Tyrant, The. Mrs. Henry de la Pasture. Under the Red Robe. Stanley J. Weyman. Virginia Perfect. Peggy Webling.

WOMan with tile Fan, The. Robert Hichens.

\section{Methuen's Seyenpenny Noyels}

Fcap. 8vo. 7d. net

A:Gel. B. M. Croker.

Broom Squire, The. S. Baring-Gould.

By Stroke of Sword. Andrew Baliour.

*House of Whispers, The. William Le Queux.

Human Boy, Tue. Eden Phillpotts.

1 Crown Thee King. Max Pemberton.

* Late in Life. Alice Perrin.

Lone Pine. R. B. Townshend.

Master of Men. E. Phillips Oppenheim.

Mixed Marriage, A. Mrs. F. E. Peuny.
Peter, a Parasite. E. Maria Allanesi.

Pomp of the Lavilettes, Tue. Sir Gilbert Parker.

Prince Rupert the Buccaneer. C. J. Cutcliffe Hyne.

*Princess Virginia, The. C. N. \& A. M. Williamson.

Profit And Loss. John Oxenham.

Red House, The. E. Nesbit.

Sign of the Spider, Tine. Bertram Mitford. Son of the State, A. W. Pett Ridge. 



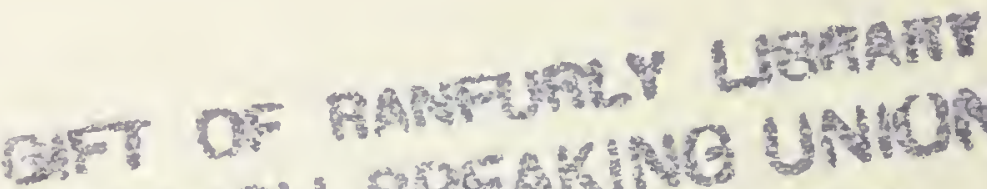

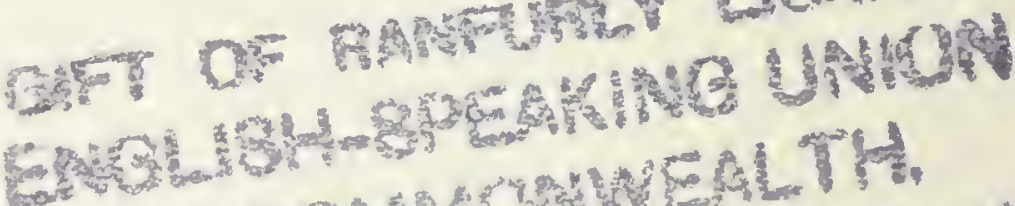

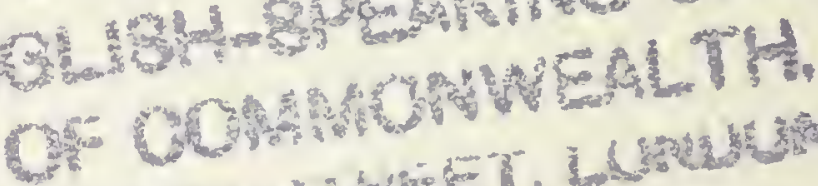

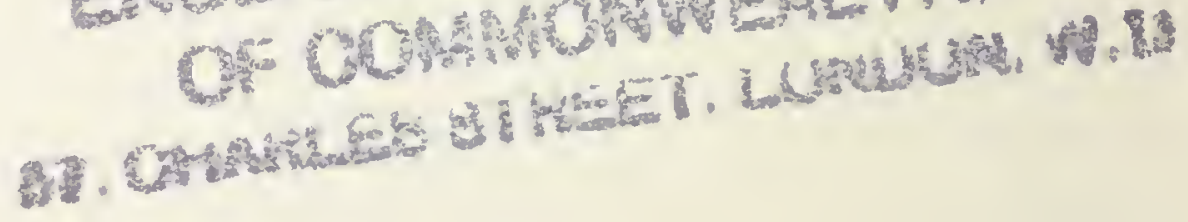



H.

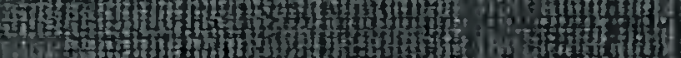

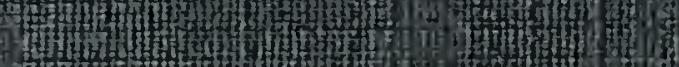

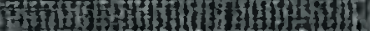

2.

42 th

(3)

thath

H.t.m

Hatm

\section{Dhom}

*hos

19.

How 3 m

H.W

thom

SIm

Him

Hown

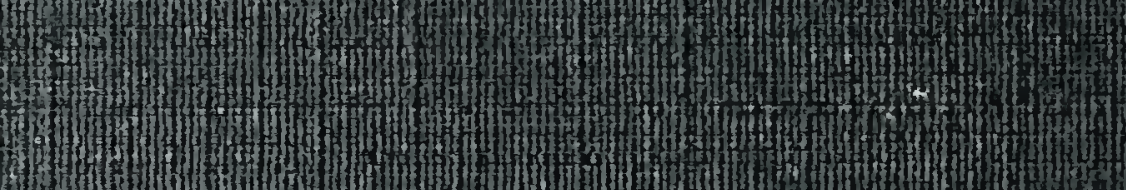

mom

Hom

Wham

H.t.

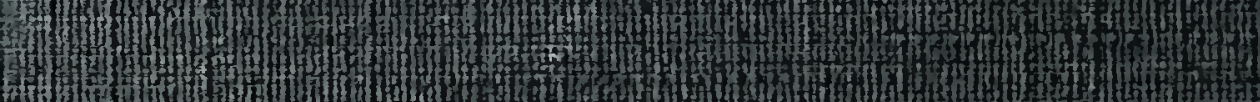

3)

14)

mom

HWH

H.

hH

In)

4.

1

H.

14

H.t.

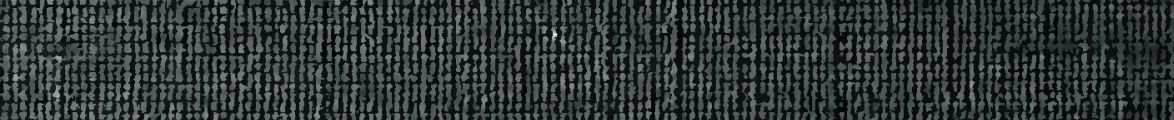

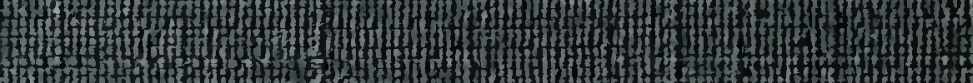

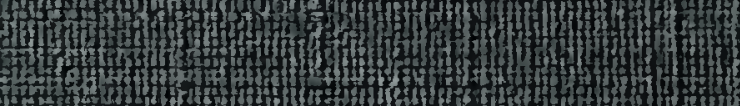

Ho

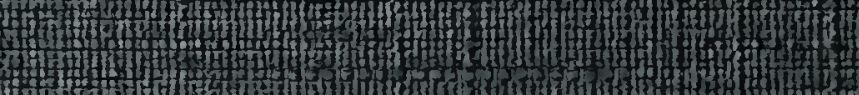

Hof

H.7.

H.

10.7.

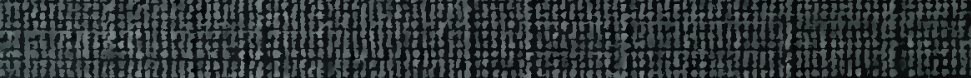

1.7010 